\title{
The Dominion State at War
}

\author{
by \\ Tristan Cordelia Egarr
}

\begin{abstract}
A thesis
submitted to the Victoria University of Wellington in fulfilment of the requirements for the degree of Master of Arts
\end{abstract}

Victoria University of Wellington 



\begin{abstract}
This thesis examines the New Zealand state during the First World War. It seeks to ask, firstly, to what extent did the economic size and legal reach of this state expand during, and because of, the war; secondly, how did was this growth affected by, and how did it impact upon, New Zealand's relationship with Great Britain? My hypothesis is that, as the wartime New Zealand state expanded in size and power, its relationship with Britain grew tighter and stronger.

Following an introduction, in which I take issue with the use of the term "nation" to describe New Zealand in the early twentieth century, the thesis is divided into four chapters. In the first, I look at the men who led the New Zealand Government during the war, in particular the Prime Minister, William Ferguson Massey, and the Cabinet Ministers James Allen, Alexander Herdman, and Joseph Ward; I also respond to the recent historical reassessments of Massey and his government. In the second chapter, I look at education policy during the war, asking how the war influenced administrator's attempts to centralise control over schools.
\end{abstract}

In the third chapter, I trace the growth of the wartime economy, and the even more substantial growth of the state's role in the economy, paying particular attention to how trade with Britain grew, and impacted upon other economic policies, suggesting that export of pastoral produce to Britain drove both New Zealand's economy, and much of the Dominion Government's policies. In the fourth and final chapter, I look at law and order policies during the war, paying particular attention to the erosion of evidence law in war regulations, and the conscription of men to fight overseas. I will ultimately argue that the growth of, and tighter control over, the pastoral export trade to Britain, and the increasing legal powers of the state within New Zealand, together constituted an expansion of the Dominion government directed at pursuing the needs of the Empire, over and above the needs of New Zealanders. 


\section{Acknowledgements}

This thesis was intended as a holistic, birds-eye-view study of the New Zealand state in its entirety - from parliament down through the various ministries and state services to every item of spending on the government's budget - during the First World War. It also intended to look at the relation of this state to its parent state, the United Kingdom, and ask how the state expanded during the war, and how this expansion was impacted by, and impacted upon, its relation with its parent.

I framed this topic so broadly because I had become aware during previous studies of the gaps and blind conclusions generated by studies of one isolated aspect of the state. Yet in framing it so broadly, it would be fair to say that I committed an act academic hubris, as the sort of totality I was aiming for is not really achievable. What I have submitted, then, is a flawed and incomplete look at the totality of the New Zealand state during the First World War, but with some sections - particularly the section on the competing legal philosophies of Robert Stout and John Salmond, and their impact on wartime legal powers - of which I am proud, and which I believe justify this rather crazy project.

In attempting to complete this unwieldy thesis, I benefited from the support and patience of five supervisors: Richard Hill from 2011 to 2015, James Belich in 2011, Brad Paterson from 2012 to 2015, and Kate Hunter and Cybele Locke in 2016. I could not have asked for better guidance, and the fact that this thesis is not more complete and polished rests solely on my shoulders. I would also like to thank the faculty and support staff of the History Department and Stout Centre, particularly Lydia Wevers, who have aided in getting me and my text to the point it has now reached, as well as those inside and out of the University who have helped along the way. I would also like to thank Peter Whiteford for presenting me with an opportunity to bring this project to its conclusion. 


\section{Table of Contents}

Page

$\begin{array}{ll}\text { Abstract } & 1\end{array}$

Acknowledgements 3

Table of Contents

Introduction: The Dominion State at War $\quad 7$

Chapter One: Political Leadership in First World War New Zealand 17

Chapter Two: Education for National Life 57

Chapter Three: Government Intervention in the Dominion Economy 79

Chapter Four: Policing and Punishment in Wartime 139

$\begin{array}{ll}\text { Conclusion } & 203\end{array}$

$\begin{array}{ll}\text { Bibliography } & 205\end{array}$ 


\section{Introduction: The Dominion State at War}

The size and power of the New Zealand state increased significantly during the First World War. Government revenue, non-military expenditure, and the public debt all doubled between 1914 and 1920. Income tax replaced land tax and customs duties as the largest source of Government revenue. Conscription and war regulations dramatically expanded police powers.

Many commentators on this period have argued that the war fed into a new sense of independence, of New Zealand nationalism. Others have said that war tightened New Zealand's imperial relationship with Britain.

It is the hypothesis of this thesis that the war did, primarily, strengthen Imperial bonds, and that this strengthening and the simultaneous growth of the Dominion state had a mutually constitutive relationship: New Zealand's ties to Britain led the Dominion to join the war effort, which effort drove the growth of the state; and this growth of state involvement in the lives of New Zealanders facilitated a stronger relationship with Britain.

The increase in the economic size and legal powers of the state was caused primarily by the needs and demands of the British Empire, rather than the needs and demands of New Zealand citizens. The effect of this increase in state infrastructure was primarily to strengthen Imperial ties, rather than to make New Zealand more independent or nationalistic. However, there are significant exceptions to both of these statements instances of the state growing in response to local demands and needs, sometimes at the expense of the imperial centre; and aspects of state growth which did lead to a greater degree of New Zealand independence, if not nationalism.

In presenting this argument, I have tried to maintain a focus on the state as a totality. Demands for an increase in funding to one area of the public sector either require decrease in funding to another sector, or an increase in the total revenue take. Similarly, increased Government involvement in one sector will have a significance for other sectors - for example, it is widely accepted that the effectiveness of education and welfare policy determine much of the requirements of justice policy. The two most important state 
functions, at least in terms of this study - economic supervision and the creation and policing of legislation - are intimately intertwined. Each increase in economic control required new legislation which could be challenged in court, and increased judicial and policing power required increased taxation or changes to the distribution of revenue. By considering each aspect of the state as part of a larger whole, I have attempted to avoid the flaws often present in accounts of one part of the state's role in the community examined in isolation.

Nevertheless, constraints of space and time obviously mean that some aspects of government will receive greater attention here than others. My first chapter will examine the role of Cabinet Ministers and Members of Parliament in driving public policy: I begin with them as their role is to drive the government as a totality. I will argue that the Reform Government, in power for the first year of the war, embraced the expansion of state powers to fight the war, in spite of their predominantly non-interventionalist rhetoric. I will also argue that the Liberal-Reform "National" coalition in power from August 1915 pushed intervention even further, and was willing to go further than Reform alone in promoting state intervention for the welfare of individual citizens as well as the security of the Empire as a whole. Nevertheless, my analysis of parliamentary debates will demonstrate that the Government promoted duty to the state over and above the duty of the state.

In my second chapter I will look at education policy to ask how this important aspect of state intervention in the lives of the people facilitated cultural change. While the war held back the growth of state education by directing funds elsewhere, it brought new legislation demanding displays of loyalty to the Empire, and ensured a greater emphasis on New Zealand's Britishness in school textbooks.

My third chapter will examine state intervention in the economy, as the basis upon which other functions of the state are founded. The first part of this chapter looks at Government finance - revenue from taxation and other sources; expenditure; and public loans. Revenue, taxation and the public debt all doubled over the course of the war, a massive expansion of the state justified by the defence of Empire. While this increase primarily illustrates my hypothesis, the Government's need for loans to finance the war effort forced it to seek 
more funding from local sources (instead of the London money market), facilitating a greater degree of financial independence.

This part of the economics chapter also examines the Imperial commandeer of $\mathrm{New}$ Zealand's pastoral exports, and the related attempts at fixing the prices of commodities for the domestic market. The commandeer accounted for more than half of all the Dominion's exports from 1915 to 1922 , and is perhaps the single best demonstration of my hypothesis: the demands of the war effort driving a significant expansion of state intervention in a way that tied New Zealand to Britain. However, the growth of this export trade and increased prices caused problems for local consumers, and led to a Board of Trade which fixed prices on the local economy - war-driven Government growth in the direction of aiding individual citizens.

Another part of my economics chapter focuses on Government intervention in the property market - mortgage and rent controls, and the provision of land to returned servicemen. I will look at how willing the Government was to include soldiers from Great Britain in land settlement schemes, and also at how the failure of the schemes required ongoing Government involvement in assisting farmers long after the war was over. The initial unwillingness of the Government to settle British soldiers undermines the extent to which Government expansion (and, indeed, the war effort as a whole) was driven by loyalty to Empire; however, over ten-thousand British soldiers were settled here in the early 1920s, suggesting that the State was committed to its promises to the Mother Country, but was determined to carry out these promises in a practical manner. The ongoing involvement of the state in the lives of soldier farmers demonstrates how public support for the welfare of soldiers meant that the war drove an increased demand for Government intervention, provided those who benefitted had shown they were deserving by performing their duty to the Empire.

The final part of the economics chapter is about such increases to welfare policies driven by the war. Economic interventions aimed at alleviating the impacts of the war on New Zealanders lagged behind interventions aimed at winning the war, but the increases were significant and their impact in terms of subsequent changes to Government policies were important. Most importantly, increases to welfare spending were directed at soldiers and 
their dependants (most notably, war widows), so that while on the one hand welfare policy shows how the war drove an expansion of the state for the benefit of individual citizens, this expansion was ultimately about rewarding and facilitating service to the Empire.

Having examined the quantitative growth of the state, I will then turn to the qualitative change in justice policy: how the war facilitated important changes to the rule of law, particularly around the law of evidence. War Regulations allowed the Cabinet to make extraordinary changes to police and judicial powers without reference to Parliament, and usually without much in the way public opposition. Conscription, introduced in 1916, gave the New Zealand Government unprecedented power over the lives of its citizens, stirring up significant opposition both within and without Parliament. Unlike the growth of economic intervention during the war, which primarily led to a tighter relationship with Britain but also benefitted individual citizens and created some new degree of independence, increases to police and court powers were solely in the direction of making individual New Zealanders subservient to the needs of Empire, the duty of the state to its people subservient to the duty of the people to the state.

\section{Historiographical Background: The Misuse of 'Nation'}

That the First World War drove the growth of the role of central states in the nations fighting the war is historiographically uncontroversial. A.J.P. Taylor and David Kennedy have described the war as a turning point in gaining public acceptance for a strong central state, overcoming the anti-statist traditions of Britain and the U.S.A. ${ }^{1}$ Robert Higgs has used this fact to argue that the massive growth in the welfare state in the United States in the earlytwentieth century was due to a series of crises, rather than the overarching need of the populace for economic redistribution; his argument has been picked up by Michael Bassett and applied to New Zealand: like Higgs, Bassett uses the importance of military crises in spurring on state intervention as an argument against the ideal of the welfare state as a

\footnotetext{
${ }^{1}$ A.J.P. Taylor, English History 1914-1945 (London: Oxford University Press, 1965); David M. Kennedy, Over Here: The First World War and American Society (New York: Oxford University Press, 1980).
} 
benefactor of humanity. ${ }^{2}$ On the other hand, David Kennedy describes how many believers in the welfare state used the war as an opportunity to further social programmes which would otherwise have run into opposition. ${ }^{3}$ While the example of New Zealand could thus be seen as an unremarkable case study among debates over the efficacy of state interventions propelled by war, New Zealand, and the other British settler Dominions, are remarkable in that the growing power of their state apparatuses cannot be placed into a "nation-state" narrative: there was no such thing as a New Zealand citizen at the time of the war. New Zealanders were British Citizens and regarded themselves as members of a British Nation; they possessed an independent internal government, but this state was not truly sovereign in that there was no possibility that it would form its own foreign policy.

One long-standing historiographical tradition is to read the impact of the First World War on New Zealand as an impetus for greater independence. Keith Sinclair saw the First World War as a milestone in the growth of New Zealand's sense of independence: "After the war there was a very general agreement among the New Zealanders that they were a new nation." 4 Michael King replaced Sinclair's nation-building reading with an emphasis on imperial duty: "the conviction that the Empire as a whole would never put a foot wrong in matters of principle and foreign affairs". ${ }^{5}$ Stevan Eldred-Grigg ended his recent history of New Zealand during the war with a chapter titled "Nation or Empire?", and argued that New Zealand both could and should have refused to follow Britain into the conflict. ${ }^{6}$ Regardless of whether New Zealand should have refused to participate in the First World War, to claim that such a refusal was plausible is to ignore the realities of New Zealand's geopolitical status in 1914. Furthermore, the distinction between nation and empire is false: New Zealanders used the term "nation" primarily to refer to Britain, so that nation and empire were one and the same; the islands in which they lived were merely a "country". In forwarding such an assertion, I draw on James Belich's argument that New Zealand was culturally "re-colonized"

\footnotetext{
${ }^{2}$ Robert Higgs, Crisis and Leviathan: Critical Episodes in the Growth of American Government (New York: Oxford University Press, 1987), p.123, 157-8; Michael Bassett, The State in New Zealand 1840-1984: Socialism Without Doctrines? (Auckland: Auckland University Press, 1998), p.123.

${ }^{3}$ Kennedy, p.34.

${ }^{4}$ Keith Sinclair, A History of New Zealand, $2^{\text {nd }}$ edn. (Harmondsworth: Penguin, 1969), p.233.

${ }^{5}$ Michael King, The Penguin History of New Zealand (Auckland: Penguin, 2003), p.293.

${ }^{6}$ Stevan Eldred-Grigg, The Great Wrong War (Auckland: Random House, 2010), p.462-7.
} 
on the basis of tighter economic links to Britain from the 1880 s. $^{7}$ The sense of imperial unity and brotherhood which followed the shared sacrifice of the war effort brought about an era in which New Zealand's lawmakers paid more deference to British precedence than they had in the pre-war era, and an era in which the Dominion's economy became increasingly dominated by one sector - the export of pastoral produce - and one market, Britain. ${ }^{8}$

My claim that historians are wrong to contrast New Zealand as a "nation" with the British Empire deserves some qualification. When, exactly one year after the declaration of war, the leaders of New Zealand's two major parties followed Britain's lead in forming a coalition government, they also followed Britain in calling this coalition a "National Government". ${ }^{9}$ The use of the term "National" was not unusual, as many New Zealand-wide institutions were entitled "National", such as the National Provident Fund, National Efficiency Board, and National Registration. During debate over the Military Service Bill in 1916, members of parliament used phrases such as "national service" and "national defence" to describe the proposed plan. Yet they rarely, almost never, used the term "Nation" to describe New Zealand.

During the three readings of the Military Service Bill in the House of Representatives, New Zealand was referred to 89 times as a "Dominion", 297 times as a "country", while "nation" was applied directly to New Zealand only twice. ${ }^{10}$ Reform MP David Buick stated that Gallipoli had "made us a nation" - here using the word quite purposefully to indicate a transition away from being a mere British country to a nation in its own right. ${ }^{11}$ Similarly, Liberal Cabinet Minister George Russell asked "what would become of New Zealand as a separate nation" if Germany won the war; in this case, the word is used in the future-tense, to indicate how losing the war would split New Zealand's ties from the British nation. ${ }^{12}$ In contrast, the term 'Nation' was used to describe Britain approximately fifty times, often

\footnotetext{
7 James Belich, Paradise Reforged, (Auckland: Penguin Books, 2001); Geoff Bertram, "The New Zealand Economy, 1900-2000," in Giselle Byrnes ed., The New Oxford History of New Zealand (Melbourne: Oxford University Press, 2009), p.544, 553-4.

8 Peter Spiller, Jeremy Finn, Richard Boast, A New Zealand Legal History (Wellington: Brookers, 1995), p.116.

${ }^{9}$ Australia's coalition government was referred to both as the National Government and, uniquely, as the Nationalist Government, though I have so far been unable to find a single historian who has considered this fact worth commenting upon.

${ }^{10}$ NZPD 1916, vol.175, p.484-786.

11 NZPD 1916, vol.175, p.628.

12 NZPD 1916, vol.175, p.764.
} 
interchangeably with 'Empire' ${ }^{13}$ In closing the Second Reading debate, James Allen made the status of New Zealand as a part of the larger British nation explicit, describing "New Zealand's voluntary effort to assist the nation in this time of trial". ${ }^{14}$

Consequently, I believe the contrast between nation and country to describe Britain and New Zealand was quite intentional, in spite of the application of the term national to New Zealand-wide institutions - the latter fact was, I believe, simply a case of imitating British precedent. Yet as David Buick's statement makes clear, there were some who thought positively about the idea that New Zealand could break away from Britain to become a nation in its own right. The "Nation" of "Our Nation's Story", a primary-school history textbook published in the inter-war years, refers to Britain, while New Zealand is still a "country": the Preface promises to teach the reader both about "his own country" and "the historical progress of the nation of which he is a citizen" - all New Zealanders being British Citizens at that time. ${ }^{15}$ Yet at one point, the authors ponder the future of New Zealand, stating "the work of building for New Zealand is but beginning. There is yet much to be done for our country. We must build a national literature, a national music and a national art; and above all we must develop that which we already possess in no small measure - a New Zealand national spirit." 16

In spite of New Zealand's loyalty to the Home Nation, this desire for future independence shows up in parliament during criticism of the hierarchical, class-based organisation of the British Army. During the 1916 Address in Reply, Liberal MP Richard McCallum stated that "whereas the Home workmen - from whom the "Tommies" are drawn" were "more or less a servile class", New Zealand's workers and soldiers had "free instincts and independent feelings", so that requiring them to follow British military regulations such as saluting officers when off duty was insulting. Worse, McCallum complained that in Egypt New Zealand privates had been prohibited from sharing first-class hotels and railway carriages with officers even though many of the privates occupied "better positions - socially and

\footnotetext{
${ }^{13}$ Great Britain and Britain were the preferred terms, though England was used occasionally; United Kingdom, although the "correct" term, was used by Massey but rarely by anyone else. 'Home', 'Home-country', 'Oldland', 'Old-country', 'Mother-land' and 'Mother-country' also appeared with some frequency.

${ }^{14}$ NZPD 1916, vol.175, p.647.

${ }^{15}$ Our Nation's Story: Standard VI (New Zealand: Whitcombe and Tombs, c.1928-35) - date of publication based on statement p.248 that the three main parties in the country at the time were United, Reform and Labour.

${ }^{16}$ Our Nation's Story: Standard VI, p.65.
} 
financially - than their officers." ${ }^{17}$ Even more worrying, McCallum claimed that this custom had "crept in in New Zealand", noting one case where a private had been "ordered out of the first-class carriage by one of the officers at Trentham" despite having a first-class ticket; and another where an officer refused to be seated at the same table as a private. ${ }^{18}$ Later in the year, Labour MP Alfred Hindmarsh asked James Allen about a similar incident where a private soldier who was also a veteran of the Boer War was ordered out of a first-class carriage so that two much younger officers could have it to themselves. ${ }^{19}$

Thus, despite overwhelming support for the British war effort, this tension between New Zealand freedom and British class distinctions brought into question the distinction between New Zealand as a mere country and Britain as the nation to which it adhered. The examples quoted in the last paragraph add weight to Sinclair's nation-building thesis. Yet the bulk of the evidence - the overwhelming use of the term "nation" to refer to Britain - suggests that movement towards greater independence was limited.

The purpose of this thesis is to demonstrate the growth of central state power not as a sovereign nation-state, or even in the direction of becoming a nation-state, but as a part of a larger imperial federation. Wartime increases to the power of the Dominion State were primarily aimed at strengthening imperial ties, and such ties in term served to strengthen, not dilute, the power of the subject state.

I am not particularly concerned with whether joining in the First World War was in the interest of New Zealand as opposed to Britain. Richard Kay's study of New Zealand-British relations during the war argues that the fall of the British Empire would have been a disaster for New Zealand, and thus that New Zealanders fought for New Zealand. This argument provides an effective counterpoint to suggestions that the war was contrary to New Zealand's interests, but I believe Kay goes too far in arguing that the war was thus fought for local rather than Imperial reasons. ${ }^{20}$ New Zealand's contribution to the war effort - in particular, the high rate of reinforcements it sent relative to other Dominions - was out of proportion to the benefits New Zealand could gain from the war. The high reinforcement

\footnotetext{
${ }^{17}$ NZPD 1916, vol.175, p.173.

${ }_{18}$ NZPD 1916, vol.175, p.174.

${ }^{19}$ NZPD 1916, vol.176, p.56-7.

${ }^{20}$ Richard G.H. Kay, "In Pursuit of Victory: British-New Zealand Relations During the First World War" (PhD Thesis: University of Otago, 2001), p.53-4.
} 
rate which drove the introduction of conscription, and with it many of the most draconian war regulations, was intended primarily to impress Britain, and was not militarily necessary to ensure New Zealand remained British. In contrasting how the Government was eager to introduce wartime policies which aided the Imperial war effort, often at significant expense to the rights of local citizens, with the reluctance of our leaders to intervene in ways which alleviated the impact of the war on such citizens, I will demonstrate how the duty of citizens to the Empire was promoted over and above the duty of the Empire to its citizens.

\section{A Note on Primary Sources}

The rock of evidence upon which this thesis was built is Hansard: embarking upon this project, my first task was to read the New Zealand Parliamentary Debates from the beginning of 1914 to the end of 1918, and to a more selective extent before and after. I paid particularly close attention to the 1916 debates over the Military Service Act, not just for what these debates said about that particular piece of legislation, but for what politicians' speeches on the subject said about their views of New Zealand's relationship to Britain, and their views on the duty of the state to its people, and of the people to the state - keeping in mind, of course, the particular, and high charged, context of that debate.

The second major primary source I drew upon has been the official government reports collected in the Appendices to the Journals of the House of Representatives, supplemented, for the statistics in the economics chapter, by the New Zealand Official Year Books. I have also used the Gazette and the Law Reports, besides the text of legislation passed by Parliament, to analyse the laws of the period; and drew upon a large number of newspaper articles for a sense of how the government's actions were received by various different sections of the public. Unfortunately, few of the politicians of this time have left particularly thorough records of their actions in the archives - save for James Allen, whose papers in the New Zealand Archives have been invaluable, particularly his correspondence with Massey while the latter was overseas. Consequently, records kept in Archives New Zealand and the Alexander Turnbull Library have not formed as significant a role in this thesis as I might have liked, but a small number of such records have been of great significance. 


\section{Political Leadership in First World War New Zealand}

William Fergusson Massey's Reform Government came to office in July 1912, seven months after the inconclusive election of 1911, when defections from the Liberal Party forced it out of office after twenty-one years in power. Their first legislative big moves were to make freehold title available to all farmers on crown leasehold land, and to institute a Public Service Commissioner to reduce executive influence over the civil service. They were also committed to ending the practice of short-term borrowing to fund public works, but almost immediately found this pledge impossible to keep. They made significant changes to defence policy, most notably in taking the first steps towards setting up a local navy. After forcibly crushing miners' and waterside workers' unions with help from territorial soldiers, the Imperial Navy and a willing Police Commissioner, Massey's government tightened up the laws government union activity. In these first two years in power they also repealed the Second Ballot Act, almost certainly making it easier for the party to retain control of the executive at subsequent elections. Although they built upon rather than against the work of the Liberals, Reform were a conservative party, one often labelled by historians as a party of violent anti-worker and bigoted anti-Catholic sentiment. However, over the last two decades a number of historians have sought to revise these assumptions, portraying Massey and his deputies instead as a broad-based party who did much to improve the welfare of all New Zealanders and worked with those who held opposing religious beliefs to seek compromise for the good of the Dominion and the Empire.

This chapter seeks to discover the political ideologies of Massey and two of the most influential members of his war cabinet - Alexander Herdman and James Allen - and to provide and understanding of the tactics they drew on to maintain and utilise executive power over the course of the First World War. While Reform held office alone throughout the first year of this conflict, on the anniversary of declaration of war Massey and his main opponent, Joseph Ward, formed a coalition government in spite of significant personal animosity, and I will also trace the ideologies and actions of Ward and his deputies (particularly George Russell and W. D. S. MacDonald). Of these leaders, only Ward is the subject of a full biography by a professional historian - albeit one almost as unsympathetic 
as most of the traditional portraits of Massey as a narrow-minded bigot. In describing these men, I will engage with the recent revisionist histories of Reform, and while I acknowledge that these revisions provide important caveats to the accepted picture, I find the latter to be closer to the truth. Ultimately, however, my interest in these men is not in such historiographical debates, but in their attitudes towards two issues. First, their attitude towards the role of the state, and how, in spite of campaigning against the extension of state power, Massey and his men oversaw one of the most significant ears of expansion in both the size and power of government in the history of New Zealand. Second, their attitude towards Empire, and the fact that Massey steered an expansion in the size of his governing apparatus not so much towards the end of improving the welfare of the people of New Zealand - though this did happen for at least some New Zealanders - but towards the end of serving the demands of Britain.

\section{The Rise of William Massey: "farmers can do without the assistance of the Government,}

\section{but Government cannot do without the assistance of the farmers." 11}

William Fergusson Massey was born in Northern Ireland on the ten acres leased by his father, a Presbyterian tenant farmer. When his family emigrated in search of the opportunity to own their own property, he stayed back to complete his schooling. By the time he landed in Auckland at the age of fourteen to work with his family, his father had given up on the unpromising land granted to him by the government for paying his way out, and instead returned to leasing. After a couple of years, Bill left for Canterbury to serve an apprenticeship in modern farming methods under substantial station-owner John Grigg. Returning to Auckland, he set out on his own by 1877, leasing a hundred acres and purchasing a threshing machine which provided an immediate cash income. ${ }^{22}$ He married a neighbour's daughter, Christina Allan Paul, in 1882, and together they began to work their way through local politics, with Bill serving on the Mangere School Committee and Road

\footnotetext{
${ }^{21}$ NZPD 1904, vol.128, p.22.

${ }^{22}$ W.J. Gardner, William Massey (Wellington: A.H. \& A. W. Reed, 1969), p.4-6; Barry Gustafson, "Massey, William Ferguson," in Dictionary of New Zealand Biography, Te Ara - the Encyclopedia of New Zealand, updated 30-Oct-2012, URL: http://www.TeAra.govt.nz/en/biographies/2m39/massey-william-ferguson; D. Christine Massey, The Life of Rt. Hon. W. F. Massey P.C., L.L.D., Prime Minister of New Zealand 1912-1925 (Auckland: D. Christine Massey, 1996), p.12
} 
Board and participating in the local Presbyterian Church and Freemasons' lodge. His future political prospects were developed as chair of the Mangere Farmers' Club which then revived - and elected him president of - the Auckland Agricultural and Pastoral Association in 1890; the following year he became vice-president of the conservative National Association formed in Auckland to oppose the south island-dominated Liberal Association. ${ }^{23}$

The National Association was dominated by businessmen who opposed the "socialistic tendency" and land tenure "experiments" of the Liberals. Massey provided them with a voice for the small-farmers of the "roadless north", many of whom felt neglected by the Liberals' focus on busting up the big southern estates. Although he demonstrated from the first the "strict party loyalty which he was later to expect of his followers", his political aims were fairly similar to those of the Premier he was in 1894 elected to oppose. Richard Seddon described Liberal policy in 1893 as beginning and ending with "the settlement of the people on the land", to be achieved by subdividing large estates and developing roads while avoiding heavy borrowing. ${ }^{24}$ Addressing the Lands for Settlements Bill in his maiden speech, Massey stated that he recognised "the evil" of large, undeveloped estates standing in the way of settlement, but he "could not agree with the proposal to take land compulsorily, for besides destroying the security of freeholds, it would be putting too much power into the hands of people who might not always use it properly." He argued that, rather than expending large sums of money to confiscate southern estates and road them, the government should focus on providing infrastructure to his own undeveloped north, and suggested that once the State affirmed "the principle of taking land compulsorily" it might not stop at large absentee landlords, but extend to "the small landowner tomorrow." In conclusion, he affirmed "the security of freehold" as central to "the aspirations of the AngloSaxon race" and appealed to "the rights and liberties" of Magna Carta. ${ }^{25}$ Eight years later, he described "the desire that each man should possess his own land" as "inherent in the people of our race." 26

\footnotetext{
${ }^{23}$ Gardner, William Massey, p.7; Gustafson, "Massey, William Ferguson."

${ }^{24}$ The Colonist, 15 November 1893, p.3

${ }^{25}$ NZPD 1894, vol.83, p.656-8.

${ }^{26}$ NZPD 1902, vol.121, p.223; Brad Patterson, "'Every man his own landlord': Mr Massey and the Fight for Freehold, 1894-1912," in James Watson and Lachy Paterson ed., A Great New Zealand Prime Minister? Reappraising William Ferguson Massey (Dunedin: Otago University Press, 2011), p.56.
} 
In spite of this speech, after achieving the Prime Minister's office he would cite the fact that he did not divide the House over the Bill as evidence that he had, in fact, supported the division of the large estates. ${ }^{27}$ Massey's political evolution away from strict adherence to the National Association's anti-statist policies to a promotion of intervention when it served the interests of the small farmers, opposition to interference when it did not, showed a shrewd political understanding, but it also reflected a genuine expression of Massey's life experience. W.J. Gardner suggested that the Reform slogan "every man his own landlord" reflected his Irish background, in particular support for the "Ulster tenant rights movement", but Brad Patterson has argued that in fact this ideology was also confirmed by his family's move to New Zealand. Massey's father had been attracted to the colony by a government grant which turned out to be unfarmable, and "it is likely that Massey senior's subsequent distrust of government land settlement schemes was transferred to the son". ${ }^{28}$ But the "busting-up" of large estates was politically popular, and Massey would come to see that it had advanced his desire for closer settlement; Tom Brooking has pointed to a "radical shift in attitudes to property" by conservative businessmen and landowners who came to see the "guarantee of fair prices" provided for under the Lands for Settlement as "more important" than the strict defence of private property; given that Native Title land could be taken without either the consent of the owners or fair price, a strict defence of property rights would not have worked in late-nineteenth century New Zealand, where the desire to develop the young colony by getting people onto the land trumped all other political issues. $^{29}$

By the time he was elected official leader of the opposition in 1903, Massey had come to accept that affirming old-style conservatism was political suicide in the face of the Liberals' total dominance of colonial politics. According to his granddaughter, his decision to shave off his beard before the 1909 elections marked a symbolic embrace of a new politics. ${ }^{30}$ By taking as his party's name Reform, Massey suggested a combination of the best achievements of the Liberals - the promotion of the welfare of small-farmers and smallbusinessmen in the face of old-world interests - with the best conservative traditions of

\footnotetext{
${ }^{27}$ NZPD 1912, vol.158, p.188.

28 Patterson, p.51-2.

${ }^{29}$ Tom Brooking, "Use it or Lose it: Unravelling the land debate in late nineteenth-century New Zealand," New Zealand Journal of History 30, 1 (1996), p.150-1.

${ }^{30}$ D. Christine Massey, p.26.
} 
Magna Carta and individualism. From the start of his career, he positioned himself as an opponent of government borrowing: arguing against the Advances the Settlers Bill, he acknowledged the need for settlers to get money "as cheaply as possible", but tried to demonstrate that any land the Government invested in with borrowed overseas capital amounted to land sold to foreigners. ${ }^{31}$ In 1912, shortly before coming to power, he tried to portray his opponents as believing taxpayers were "made to be taxed". ${ }^{32}$ Having argued so consistently against state borrowing, he was forced to backtrack, stating that he was not "hostile to borrowing": on the contrary, he just "desired to borrow at the right time and at the lowest possible rate, and then to spend the money to the best advantage for the benefit of the country." ${ }^{33}$ Massey's Finance Minister, James Allen, had been critical of the previous administration taking out short-term loans on the London market, but within months of achieving office, found "political necessity and developmental imperatives" required Reform to continue these very same policies. ${ }^{34}$

Fortunately for Reform, by this point opposition to the option of the freehold for those farming on government leases had become almost as politically suicidal as defending the interests of the big estate-owners. The Liberals, who had prided themselves for over a decade as representing the interests of all New Zealanders - barring, of course, the largest property owners - were now rent apart by disputes between those who wanted further moves towards government ownership, and a larger group who agreed with Massey in preferring to extend the freehold. In spite of the success of John McKenzie's leasehold schemes in getting over ten-thousand farmers onto the land, freehold "was easily the predominant tenure", and as these farmers prospered, the demand for the freehold grew louder. ${ }^{35}$ Seddon, by sheer force of personality, had kept the Liberals together, but after his death in 1906 his successor, Joseph Ward, struggled for six years to appease either side, alternatively introducing and withdrawing legislation to reform land tenure. ${ }^{36}$

\footnotetext{
${ }^{31}$ NZPD 1894, vol.86, p.44-5.

32 NZPD 1912, vol.158, p.113.

${ }^{33}$ NZPD 1912, vol.158, p.123.

${ }^{34}$ Ian McGibbon, "Allen, James," in Dictionary of New Zealand Biography, Te Ara - the Encyclopedia of New Zealand, updated 30-Oct-2012, URL: http://www.TeAra.govt.nz/en/biographies/3a12/allen-james

${ }^{35}$ Brooking, p.159.

${ }^{36}$ David Hamer, The New Zealand Liberals: The Years of Power, 1891-1912 (Auckland: Auckland University Press, 1988), p.290-305.
} 
On the 2 nd of July 1912, Massey introduced the motion of no confidence that would finally send the Liberals out of office. He began by stating that twenty years of Liberal land policy had failed to promote closer settlement to the point where farmers would stay in the Dominion, since while such policies had got them onto the land, they were not provided with the security that only the right to purchase could offer. ${ }^{37}$ He then went on to outline the Liberals' divisions over land policy, arguing that they were "the most heterogeneous collection of men" who "ever sat on the Treasury benches", and that "a house divided against itself cannot stand." 38 This argument proved prophetic, as five men crossed the floor to support Massey's motion. ${ }^{39}$ By the end of the year, Massey had passed a Land Laws Amendment Act extending allowing all farmers on the State lease-in-perpetuity to purchase the fee simple to their land. ${ }^{40}$ Introducing the Bill before parliament, Massey stated that he did not have "the slightest objection to leasehold tenure" if that was what farmers wanted, rather that all should be allowed the security of private property. ${ }^{41}$ In fact, while this seemingly simple issue had provided Massey with the bulk of the political capital with which he had risen to the highest office in the land, less than a third of the ten-thousand plus lease-in-perpetuity farmers took up the freehold option over the next two decades. ${ }^{42}$ Nevertheless, in his first year in office, Massey put an end to a debate which had dominated New Zealand politics for over a decade, allowing other issues to take its place.

\section{Alexander Herdman: The Heavy Hand of the Law}

The other major issues on the Reform agenda for 1912 were reforming the civil service and ensuring that the Federation of Labour was not allowed to achieve victory in the industrial conflict at Waihi goldmine. Solving these problems to the satisfaction of Reform's voters was the responsibility of the man Massey appointed Attorney-General and Minister of Justice and Police, Alexander Lawrence Herdman. Although F. H. D. Bell, the leader of the Legislative Council, was the most experienced and "accomplished" lawyer in Massey's cabinet and was given nominal charge of the Crown Law Office (though acting under the guidance of the Solicitor-General John Salmond), Herdman was made responsible for the

\footnotetext{
${ }^{37}$ NZPD 1912, vol.158, p.104.

${ }^{38}$ NZPD 1912, vol.158,], p.111.

${ }^{39}$ Michael Bassett, Sir Joseph Ward: A Political Biography (Auckland: Auckland University Press, 1993), p.214-5.

${ }^{40}$ Land Law Amendment Act 1912, s.31.

${ }^{41}$ NZPD 1912, vol.161, p.276.

42 Patterson, p.59; J. B. Condliffe, New Zealand in the Making $2^{\text {nd }}$ edn. (London: Allen and Unwin, 1959), p.261.
} 
administration's justice policy as he was a much stauncher supporter of both Massey and of crushing the Federation of Labour. ${ }^{43}$ A decade younger than Massey, Allen and Bell, Herdman had studied law while working for the National Bank in Dunedin, before establishing a legal practice in rural Otago; following a term as mayor and another as a Parliamentary representative he moved his practice to Wellington, and lost his Otago seat in 1905 before standing successfully for Wellington North in $1908 .{ }^{44}$

In his first speech on returning to parliament, Herdman paraphrased Plato to suggest that the "State was best governed in which the administrators were most reluctant to govern" and censured the "existing régime" for extending their reach: a child born in the new Dominion came under "the superintendence and charge of the Government", his birth was registered, he was vaccinated, compelled to attend a state school, and if, upon reaching adulthood, found he had "neither brains nor determination to find work for himself" the Government would find it for him, perhaps "on the cooperative works", before providing a State pension and State burial. ${ }^{45}$ Herdman stated that New Zealand politics was divided into the "devotees" of "Seddonism," and their opponents; that the former were spending "large sums of public money" not "for the purpose of furthering the interests" of the country, but to keep the civil service in their pocket; and that one did not get "statesmanship" in New Zealand, but "expediency", whereby the civil service was stacked with "friends of Ministers, and friends of friends of Ministers." 46

He also censured the government for writing a speech from the throne - delivered by a Governor "speaking as His Majesty's representative" - which cast "aspersions" on the Privy Council, and advocating its modification to encourage representation from areas of the Empire outside the British Isles. Herdman described the law of New Zealand as consisting of the law of England built upon by the work of the Assembly, and that to administer this law, the Dominion needed to draw upon "the best expert legal opinion the British Empire"

\footnotetext{
${ }^{43}$ Sir David Smith, "Sir Alexander Herdman" (AT: MS-Papers-11112-012), p.1; W. J. Gardner, "Bell, Francis Henry Dillon," in Dictionary of New Zealand Biography, Te Ara - the Encyclopedia of New Zealand, updated 5Jun-2013 URL: http://www.TeAra.govt.nz/en/biographies/2b16/bell-francis-henry-dillon.

${ }^{44}$ Susan Butterworth, "Herdman, Alexander Lawrence," in Dictionary of New Zealand Biography, Te Ara - the Encyclopedia of New Zealand, updated 30-Oct-2012, URL:

http://www.TeAra.govt.nz/en/biographies/3h18/herdman-alexander-lawrence.

45 NZPD 1908, vol.123, p.197.

46 NZPD 1908, vol.123, p.198.
} 
possessed, which resided in England. ${ }^{47}$ On the other hand, when discussing proposals to reduce tariffs in order to encourage free-trade within the Empire, Herdman argued that that particular question should be regarded "from the point of view of the colony first and the Empire second", although he also advanced, as one reason not to embrace imperial freetrade, the fact that Great Britain had not yet made up her mind on the matter. ${ }^{48}$

While Herdman's appeal to the leadership of Britain was inconsistent, his campaign to reduce Ministerial interference in the civil service was utterly consistent, something his opponents noted when he introduced the Public Service Act $1912 .{ }^{49}$ Herdman quoted the conclusion of a Royal Commission appointed by the previous administration that "influence" was "constantly being brought to bear" on public service appointments by "members of Parliament". ${ }^{50}$ The "all-important clause" of the Bill was to put the public service under a Commissioner, appointed for seven years but who could be "suspended or removed by the Governor", who would take all appointments and promotions out of ministerial control; furthermore, such appointments and promotions were to be made on the basis of "merit", ensuring greater efficiency and the adoption of business-methods in the public sector. ${ }^{51}$ In explaining the need for an independent Commissioner, Herdman appealed to the authority of "Magna Charta" and Public Service Commissioners appointed in Britain in 1870 in response to the patronage system of Lord Palmerston, as well as Walpole and the Duke of Newcastle before him. ${ }^{52}$ Herdman's reform of the public service was largely immune to attack - Joseph Ward struggled to find reasons to oppose it, arguing weakly that merely transferring control from the hands of the Minsiters wouldn't make everything perfect which of course was not what Herdman claimed. ${ }^{53}$ The structure Herdman set up to oversee the public service remained in place for over seventy years. ${ }^{54}$

\footnotetext{
${ }^{47}$ NZPD 1908, vol.123, p.195-6.

48 NZPD 1908, vol.123, p.194-5.

49 NZPD 1912, vol.160, p.55; Alan Henderson, The Quest for Efficiency: The Origins of the State Services Commission (Wellington: State Services Commission, 1990), p.38-55.

${ }^{50}$ NZPD 1912, vol.160, p.50.

${ }^{51}$ NZPD 1912, vol.160, p.49, 51, 55.

52 NZPD 1912, vol.160, p.45-6.

53 NZPD 1912, vol.160, p.55-6.

${ }^{54}$ Henderson, p.vii.
} 
A better criticism was that large sections of the public sector - including the Police remained outside the scope of the Act. ${ }^{55}$ Retaining influence over the police was key to Herdman's next task, defeating the Federation of Labour, and he was sometimes even referred to as the "real" Police Commissioner. ${ }^{56}$ Herdman worked closely with the actual Commissioner, John Cullen, to crush the strike at Waihi that year, allowing police to violently run the striking miners out of town and even beat one miner, Fred Evans, to death. The following year, Herdman and Massey tried to use the Royal New Zealand Artillery as police during the Wellington waterfront strike, against the objections of the Chief of the New Zealand General Staff, who was supported in his objection by the Defence Minister, Allen. ${ }^{57}$ Although Herdman and Massey gave way, instead allowing the Defence Department to utilise officers in the Territorial Forces to arrange special constables to police to wharves, these constables, based in Defence Department property, had to call on Artillery protection. ${ }^{58}$ Furthermore, in using Royal Navy forces from the H.M.S. Psyche to protect the wharf in the early stages of the conflict, Herdman may have led the government to override their powers under the New Zealand Constitution Act $1852 .{ }^{59}$ Reflecting on the strike years later, the Chief of the General Staff noted that Massey and Herdman seemed to have a policy allow the strike to escalate to a point where a violent response became justified. ${ }^{60}$

As we shall see in a later chapter, Herdman was willing to use such tactics again in order to arrest the Maori religious leader Rua Kenana, and to write statutes which did away with traditional protections provided to defendants under British evidence law. Sir Hubert Ostler, acting Solicitor-General in 1913, notes that Herdman asked to appear for the Crown "on all important cases" in order to overcome his lack of experience. Ostler described Herdman as "slow and not a profound thinker" as well as "encrusted with conservative prejudices", although he also felt Herdman was "honest to the core, and gifted with strong common sense and good judgement" as well as being "absolutely fearless" during the 1913 industrial

\footnotetext{
${ }^{55}$ NZPD 1912, vol.160, p.59.

${ }^{56}$ Mark Derby, The Prophet and the Policeman: The Story of Rua Kenana and John Cullen (Nelson: Craig Potton Publishing, 2009), p.56.

${ }^{57}$ Col. E. Heard, "Waterside-Workers Strike - October, November, December 1913," in "Aid to the Civil Power" (NA: Record Group: AD11, Box: 1, Record: 2/1, Item ID: R3885678), p.5.

58 Heard, p.9.

${ }^{59}$ Smith, "Sir Alexander Herdman," p.3-6.

${ }^{60}$ Heard, p.4.
} 
dispute. ${ }^{61}$ Herdman continued to hold personal animosity towards labour leaders for decades: after failing to win a seat at the 1935 election, he wrote to a friend that "whilst not liking to be licked" he was glad not to have to serve in a parliament led by men such as Peter Fraser and Paddy Webb, whom he had prosecuted during the First World War. ${ }^{62}$ While pointing this side of his personality, it is only fair to note that he helped defend Professor George von Zedlitz from massive anti-German hysteria during the war, and personally supported a Constable wounded in the attack on Rua for decades afterward. ${ }^{63}$

Herdman's most controversial act was to retire from parliament at the beginning of 1918 to take up a vacant position on the Supreme Court bench. Even his friend and fellow judge Sir David Smith criticised him for this: "As he was Attorney-General at the time, there were many in the legal profession who thought that he had virtually appointed himself and also that he was not sufficiently qualified as a lawyer for the position." The Solicitor-General, John Salmond, described the appointment as "a scandal."64 Others were harsher, saying Herdman had "no professional eminence," "little legal experience," was "lacking in human sympathy, and temperamentally unfitted to the high office". ${ }^{65}$ Although the appointment of Supreme Court judges was technically in the hands of the Governor, the pro-Reform Evening Post noted that the previous judge, J. E. Denniston, had wanted to retire for some time, and that he was being kept on "to suit the convenience" of the administration, who wanted to keep the seat ready for Herdman until they were ready to let him leave cabinet. ${ }^{66}$ Herdman's resignation was finally accepted a fortnight before the death of his first wife. ${ }^{67}$

\section{Putting Aside Everything for the Defence of Empire: James Allen}

While Herdman represented the heaviest hand of Massey's cabinet, the Minister of Finance, Defence and Education, James Allen, has developed a reputation for pragmatism and

\footnotetext{
${ }^{61}$ Sir Hubert Ostler, "Bench and Bar 1903-1928," in Robin Cooke Q.C. ed., Portrait of a Profession: The Centennial Book of the New Zealand Law Society (Wellington: A. H. \& A. W. Reed, 1969), p.74-5; see also Peter Spiller, Jeremy Finn and Richard Boast, A New Zealand Legal History (Wellington: Brookers, 1995), p.249.

${ }^{62}$ Sir David Smith, "Bench and Bar 1928-1950," in Cooke, p.106-7.

${ }^{63}$ Smith, "Sir Alexander Herdman," p.8; for von Zedlitz, see Education chapter in this thesis.

${ }^{64}$ Smith, "Sir Alexander Herdman," p.6-7; Smith, "Bench and Bar 1928-1950," p.91-2.

65 Northern Advocate, 26 November 1917, p.1.

${ }^{66}$ Evening Post, 21 November 1917, p.6.

${ }^{67}$ Butterworth.
} 
compromise. Had it not been for the war, it is unlikely that this would have been the case. A year older than his leader, Allen had once been seen as a potential leader of the opposition to the Liberals; had he been selected, it is likely he would have led the party in a more traditionally conservative direction, but he lacked the populism of Seddon or Massey, and would not have ever been able to mount the effective campaign the latter was able to make. As lan McGibbon put it, Allen was "never an outstanding orator" and his "solid dependability, intelligence, and practical good sense" were "offset" by "a certain dourness and lack of humour", so instead of leader he was entrusted with the assistant premiership and central portfolios of Finance, Defence and Education, an unbelievable workload, especially after the declaration of war. ${ }^{68}$ Fortunately, he was heavily experienced in all three areas.

Although he spent his first years in the antipodes, Allen possessed a Cambridge degree; he had some teaching experience from the British public school system, and much more extensive experience in administering secondary and tertiary education in New Zealand: as chancellor and vice-chancellor of the University of Otago, and as a board member of Otago Boys' and Girls' High Schools; he was also instrumental in helping set up the Dunedin Free Kindergarten Association. As a businessmen, Allen invested in mining. As a soldier, he had been actively involved in the Volunteer movement for two decades before Colonel and commander of the coastal defences of Otago Military District before resigning to become the Minister of Defence, although he remained president of the Otago Navy League. ${ }^{69}$

Allen began his time as Minister for Defence and Education by promoting two policies which were controversial and, in one case, deeply divisive: the formation of a local naval force, and changing the Education Act to allow Bible teaching during school hours. The former was embodied in legislation as a Government measure, whereas the latter, while enjoying the support of Massey, was a private members bill, and had not been approved before war broke out, and Allen withdrew the measure, recognising the need to avoid pushing divisive policies at a time when the community needed to rally together. ${ }^{70}$ Allen made his first speech to parliament, way back in 1887, to argue that "if Bible-reading in schools" was "to

\footnotetext{
68 McGibbon, "Allen, James."

69 Ibid.

${ }^{70}$ D. Christine Massey, p.40.
} 
be of any use at all" it had to be conducted "in school-hours", when the teacher had a captive audience, and cited as positive examples the policy of Germany, where religion was "the basis of education in the elementary schools", as well as forming "a very essential part of the education of children in Great Britain", both of which were "enlightened countries" that New Zealand might "take a lesson from." Whereas Massey and Allen entered parliament with speeches expressing their opposition to state intervention, Allen promoted from the first a paternalistic state, arguing the necessity for religious education since not "every home", even among the rich, was not "a fit place for a child to receive religious instruction", given that many were "debased by crime" and drunkenness. ${ }^{71}$ To have pushed for religious education for a quarter-century, and finally reach a position where it seemed within reach, only to withdraw his bill for the good of the defence of the realm, suggests both a marked ability to compromise, and a very strong belief in the defence of the Empire above all else.

Allen's Naval Defence Act of 1913 replaced the annual $£ 100,000$ subsidy which New Zealand paid Britain for the upkeep of the Royal Navy, with a plan to train New Zealanders locally for Imperial service, and obtain a cruiser to patrol local waters. Allen noted that while the Imperial Naval Conferences of 1909 and 1911 affirmed the strategic need for a centralised Imperial Navy, they had also acknowledged the rise of "individual national sentiment" among the Dominions, and recognised non-strategic elements of naval policy, including the possibility to some local autonomy within a centrally-directed force. ${ }^{72}$ Ward rubbished this scheme as overly ambitious and too expensive for a small Dominion, in spite of Allen's reassurance that it would not cost more than the $£ 100,000$ per year already being spent on the navy. ${ }^{73}$ By August 1914 the scheme was well under way, and a Bristol-class cruiser, the Philomel, had been purchased and received; but on the outbreak of war the ship reverted to Imperial control, and New Zealand would have to wait until the end of the war to continue Allen's dream.

One of his first actions as Minister of Defence was to reduce the penalty for those who refused to serve in the Territorial forces from imprisonment to military detention, as he did

\footnotetext{
71 NZPD 1887, vol.59, p.33-4.

72 NZPD 1913, vol.167, p.460-1.

${ }^{73}$ NZPD 1913, vol.167, p.471-2.
} 
not believe they deserved to be interned with, or be saddled with the reputation of, common criminals. In spite of being one of the earliest promoters of compulsory military training, and a leader of the militaristic Navy League, Allen showed by this act some sympathy with those who objected to serve. However, when introducing conscription in 1916, Allen's Act - unlike the British Act of the same year - did not contain any provision for allowing conscientious objectors an alternative to combat service. Although Allen has been praised for responding to complaints in the House by introducing an amendment to provide such an exemption, after the amendment failed he asked the House to vote against the Legislative Council's ultimately successful motion to affirm conscientious objection as a valid appeal (though it was watered down by the House almost to non-existence). ${ }^{74}$ While this action undermines some claims about Allen's willingness to sympathise with objectors, he did demonstrate an ability to reach compromise in order to end miners' strikes over the winter of 1916-7, compromise which Massey would not have made: overseas at the time, the Premier had advocated a heavier hand, but by avoiding this advice and refusing a repeat of 1913, Allen probably ensured that mass industrial conflict did not break out over the conscription issue. ${ }^{75}$

While unsympathetic to the Government's implementation of conscription, Paul Baker noted that, in spite of "personal fustiness and political conservatism", Allen possessed "the most receptive mind in Cabinet to the need for organization," and that in spite of "his aloof and patrician nature, Allen was in tune with the ethos of the nation", understanding "apprehensions" about conscription and, consequently, grasping "the fundamental truth" that it "could only work with the consent of most people." When Massey and Ward were overseas, Allen was acting Prime Minister, and worked tirelessly to keep the country together. ${ }^{76}$ On the other hand, Richard Kay has pointed out how Allen's intransigence caused problems for Massey, and delayed the formation of a National Government. Due to controversies over Allen's handling of outbreaks of illness in the Trentham Army training camp, the Liberals had initially made Allen's resignation a condition of the coalition. Massey and Bell initially offered Allen a knighthood in return for his resignation, but he refused,

\footnotetext{
${ }^{74}$ See section on Conscientious Objectors in Justice chapter for detail.

${ }^{75}$ Also detailed in Justice chapter.

76 Paul Baker, King and Country Call: New Zealanders, Conscription and the Great War (Auckland: Auckland University Press, 1988), p.228-9.
} 
forcing negotiations to drag on for weeks; Allen's son Charles later stated that his father and Massey were never close friends. ${ }^{77}$ In justifying his refusal to resign, Allen wrote to General Godley that Ward's "patriotism was skin deep" and merely a mask used to get back into government. ${ }^{78}$

\section{The Historical Reputation of Massey and his Government}

In writing his praise for Allen, Baker sought to rescue the Defence Minister from decades of historical neglect at a time when the Massey Government were still predominantly remembered as a party who beat up strikers and persecuted Catholics. Over the last quarter century, a number of historians have extended this revision to encompass Massey as well. In order to understand the New Zealand war cabinet, we must address this historical debate.

Before addressing this debate, it is worth noting the person sacrifices many members of the Government made for the war. Allen paid a particularly high price for his service: his son John died at Gallipoli, and Allen retired from politics, exhausted, shortly after the war's end. ${ }^{79}$ Massey's son was wounded at the Battle of the Somme. ${ }^{80}$ Joseph Ward had two sons at the front; Francis Bell had three, one of whom was killed; George Russell also had three, one of whom was killed. ${ }^{81}$ The Chief Justice, Robert Stout, had two sons fighting in the war, while the Solicitor General, John Salmond, had a son die in the final months of combat. ${ }^{82}$ It is important to note these losses before we address the debate over the wartime's governments treatment of its subjects.

A series of essays titled A Great New Zealand Prime Minister? Reappraising William Ferguson Massey appeared in 2011, opening with Erik Olssen's "Towards a Reassessment of WF Massey: One of New Zealand's Greatest Prime Ministers (Arguably)". Olssen, a historian

\footnotetext{
${ }^{77}$ Richard Kay, "In Pursuit of Victory: British-New Zealand Relations During the First World War," (PhD thesis, Otago University, 2001), p.99-102.

78 James Allen to General Godley, 11 May 1915 (NA: Record Group: Allen1, Box: 1, Record: M1/15, Item ID: R22336792, R22319697, R22319698)

79 McGibbon, "Allen, James"; Kay, p.101.

${ }^{80}$ Gustafson, "Massey, William Ferguson."

81 "Parliamentarians and World War I," updated 6-Nov-2008, URL: http://www.parliament.nz/en$\mathrm{nz} /$ features/00NZPHomeNews061120081/parliamentarians-and-world-war-i

82 Waldo Hilary Dunn and Ivor L.M. Richardson, Sir Robert Stout: A Biography, (Wellington: AH and AW Reed, 1961), p.199; Alex Frame, Salmond: Southern Jurist (Wellington: Victoria University Press, 1995), p.178.
} 
situated firmly within the left-wing tradition, argued that the left has treated Massey unfairly, that there was much more to him than simply the "union crusher" he has been portrayed as due to Massey's Cossacks, the special constables who forcibly ended the 1913 strike. Olssen told National Radio's Jim Sullivan that he would, on reflection, removed the Arguably or the Question Mark and assert that Massey was indeed a great Prime Minister. ${ }^{83}$ Some of the reassessments of Massey in this volume were simple exercises in demonstrating the excesses of hyperbole. For example, Glyn Harper's essay on Massey's reception by troops at the Western Front noted that negative responses to Massey's presence have to be put into the context of soldiers' tendency to grumble about authority, and the fact that they were suffering through awful conditions, so their dislike of parading before their leader was not entirely a response to the man and his policies. Pointing to Nicholas Boyack's statement that Massey received a "universally unfriendly welcome", all Harper had to do to disprove the "universally" was to point to the one interview Boyack and Jane Tollerton themselves conducted in which a returned serviceman recalled Massey's visit fondly. ${ }^{84}$ But as Harper admitted, the recollections of returned servicemen regarding Massey are overwhelmingly negative, so that while Boyack overstated his case, the case still more or less stands. ${ }^{85}$

The supposedly unfair tradition of anti-Massey writing was most memorably embodied in some brief passages from Keith Sinclair and Bill Oliver's mid-century general histories of New Zealand. According to Keith Sinclair, Massey was Richard Seddon's "equal as a parliamentary tactician" and possessed a virtue which Seddon lacked, modesty: "He could appreciate ability and welcome in his company men more enlightened than himself"; Sinclair suggested that this may have made Massey a "more admirable person" than Seddon. Yet In his view, while Seddon crossed the political divide to act as leader of all New Zealanders, Massey was narrower, more defined by his class-background as a farmers' man.

\footnotetext{
${ }^{83}$ Erik Olssen, "Towards a Reassessment of WF Massey: One of New Zealand's Greatest Prime Ministers (Arguably)," in Watson and Paterson, p.15; Sounds Historical, 30 May 2011 (National Radio, http://www.radionz.co.nz/national/programmes/soundshistorical/20110529).

${ }^{84}$ Glyn Harper, "'Old Bill Was All Right': William Ferguson Massey and the Soldiers," in Watson and Paterson, 94-5; Nicholas Boyack, Behind the Lines: The Lives of New Zealand Soldiers in the First World War (Wellington: Allen and Unwin, 1989), p.202-3; Nicholas Boyack and Jane Tolerton, In The Shadow of War: new Zealand Soldiers Talk About World War One and Their Lives (Auckland: Penguin Books, 1990), p.21.

${ }^{85}$ Boyack and Tolerton, p.89.
} 
${ }^{86}$ Sinclair quoted from a letter penned by Charles Lewis, a member of Massey's own Party, stating that the leader was "Hopelessly stereotyped in everything, lacking one original idea, unimaginative as a clam, unsympathetic as a grindstone, too conscientious to be tactful, he goes on his way guided by a hard, cold, obstinate bigotry which is proof against argument, entreaty, ridicule, or the lessons of the past." Sinclair admitted that this letter smacked of hyperbole, that it "might be phrased in less impatient and resentful terms", but nevertheless stated that it did "give some idea of Massey's qualities", that his "obstinacy and honesty" were confined by a narrow, inflexible Ulster Presbyterian outlook. ${ }^{87}$ Oliver, too, felt that Massey and his party never overcame the narrowness of their supporter base, that of "peasantry sophisticated to the use of machines", and that the Prime Minister himself was "in many respects... narrow and bigoted." 88

Following these general histories, WJ Gardiner and P.S. O'Connor in the 1960s published a series of articles on Massey's politics. Gardiner noted that the letter by Lewis quoted by Sinclair was motivated by personal animosity, as Lewis was pushed into early retirement by his leader; however, both Gardiner and O'Connor agreed that Massey never really escaped his narrow religious background, and that he supported the anti-Catholic campaign of the Protestant Political Association, albeit with some reservations - as O'Connor noted, Massey refused to appoint the PPA's Auckland secretary to an important position within his party, and strived to keep a distance from the organisation in public. ${ }^{89}$ Gardiner wrote "Massey had, in 1912, taken his stand as party leader on non-sectarian grounds, but his parliamentary supporters apparently never included any Catholics, and his party voted solidly on the Marriage Amendment Bill in 1920" (this Bill imposed a maximum two-year prison sentences on those who, following the Pope's Ne Temere decree, said that mixed marriages between Protestants and Catholics were invalid if not conducted by a priest)..$^{90}$

While criticising Massey for the narrowness of his outlook, Gardiner praised him as a great organiser and unifier - noting that while Seddon and Ward could never prevent recalcitrant

\footnotetext{
${ }^{86}$ Keith Sinclair, A History of New Zealand, $2^{\text {nd }}$ ed. (Harmondsworth, England: Penguin, 1969), p.239-41.

${ }^{87}$ Ibid.

${ }^{88}$ W.H. Oliver, The Story of New Zealand (London: Faber and Faber, 1960), p.150, 162.

${ }^{89}$ W.J. Gardner, "The Rise of W.F. Massey, 1891-1912," Political Science, 13, no.1 (March 1961), p.27; P.S. O'Connor, "Some Political Preoccupations of Mr Massey, 1918-20," Political Science, 18, no.2 (September 1966), p.29-30.

90 W.J. Gardner, “W.F. Massey in Power," Political Science, 13, no.2 (September 1961), p.26.
} 
MPs from voting against their own party, Massey imposed a solid sense of discipline on his followers, making his the first real solid party in New Zealand's political history, and making Massey a more effective internal party leader than Seddon, albeit one acting from a much narrower base of support. ${ }^{91}$ On the other hand, Gardiner noted that the two policies which brought Reform to power - the freehold for farmers living on land rented from the state, and a public service commissioner to take civil service appointments out of Cabinet's hands - were driven by Massey's belief in individualism. While Gardiner has been pointed to as part of the negative tradition of Massey historiography, I think here he was not critical enough, as his claim that Massey was driven by individualism and his claim that Massey's strongest asset was his cast-iron discipline seem to me to be contradictory. ${ }^{92}$

It is not true that Massey was simply an uneducated farmer; his speeches to Parliament are littered with lines from Shakespeare and the Bible, his family library testified to his love of the Victorian poets and novelists, and he did receive some degree of classical education. ${ }^{93}$ But it is true that his party displayed a narrowness of outlook which made it much easier to control than the broad-based Liberals. The Liberal Party contained a mix of Protestants and Catholics, freeholders and leaseholders, men sympathetic to socialism and men supportive of free trade. Joseph Ward dined with Irish Home Rule leaders during his visit Home in 1912, but included staunch protestants in his party. ${ }^{94}$ Massey's Reform Party consisted of protestant farmers and businessmen. Massey was an Orange Lodge master, and a supporter of the anti-Irish Home rule Unionist Party. ${ }^{95}$ Three months after retiring from cabinet, Herdman became Grand Master of the Grand Lodge of Freemasons in New Zealand; Massey attained the same position while still Prime Minister, in 1924, and Bell had been a Grand Master in 1894-5. ${ }^{96}$ James Allen was a life-long campaigner for Bibles-in-Schools, and according to Massey's granddaughter, he too supported the movement, since he had found solace in Book during the lonely period of his teens when his family left him behind in Ireland. ${ }^{97}$ It is thus unsurprising that Reform have a reputation as an anti-Catholic party. When Ward gave up the premiership in 1912, he accused his opponents of playing the

\footnotetext{
${ }^{91}$ Gardner, "W.F. Massey in Power," p.10.

92 W.J. Gardner, William Massey (Wellington: AH and AW Reed, 1969), p.8, 17.

93 Gustafson, "Massey, William Ferguson"; Massey, p.6, 14.

94 Bassett, p.217.

95 William Massey to James Allen, 2 January 1917, p.5 (NA: Record Group: Allen1, Box:9, Item ID: R22319675).

96 Butterworth; Gustafson, "Massey, William Ferguson;" Gardner, "Bell, Francis Henry Dillon."

${ }^{97}$ Massey, p.8.
} 
sectarian card, although his biographer Michael Bassett considered this complaint to be wallowing in self-pity. ${ }^{98}$

Rory Sweetman has addressed the picture of Massey as a protestant bigot. Following the 1919 elections in which the Protestant Political Association campaigned vigorously for Reform candidates, Massey made New Zealand the first British country to pass legislation against speaking in favour of the papal decree against mixed marriages, and the only one to force a Catholic bishop to defend his political views in court; during the war, New Zealand had been the only British country where Catholic clergy were conscripted for military service. ${ }^{99}$ But Sweetman contested the claim that Massey "found it difficult to discard" his religious upbringing, arguing that his essence is to be found "in the fervour of his imperialism... rather than his religious upbringing." 100 In his book Bishop in the Dock, Sweetman demonstrated how Massey sometimes sought to temper the demands of the PPA and prevent Bishop Liston's trial from inflaming religious hatred. ${ }^{101}$ Sweetman claimed that Massey used the PPA for their support while passing the minimum possible legislation possible to keep them in check, and that by taking their support he undermined their ability to inflame anti-Catholic feeling - the very success of the PPA's chosen party meant that they could no longer claim New Zealand's government was stacked with Catholics. ${ }^{102}$

Be this as it may, Sweetman failed to address Gardiner's claim that Reform contained no Catholic candidates, a claim their voting record on the Marriage Amendment Bill suggests is accurate; nor does his revaluation explain the treatment of Catholic clergy under the Military Service Act. It is true that Massey grew tired of the PPA, and tempered their demands; but he did use sectarian sentiment to attain and maintain power, and this cannot be written off as just smart politics.

Besides using sectarianism to hold onto the reins of government, Massey also manipulated the electoral system. In 1908, the Liberals passed a Second Ballot Act to ensure every Member of the House of Representatives had to achieve a majority of the votes in his

\footnotetext{
${ }^{98}$ Bassett, p.205-6.

${ }^{99}$ Rory Sweetman, "'Beery Bill the Orangeman': Another Look at William Ferguson Massey," in Watson and Paterson, p.78-9.

${ }^{100}$ Sweetman, "Beery Bill the Orangeman," p.79, 86.

${ }^{101}$ Rory Sweetman, Bishop in the Dock: The Sedition Trial of James Liston (Auckland: Auckland University Press, 1997).

${ }^{102}$ Sweetman, "Beery Bill the Orangeman," p.78-81.
} 
electorate to reach parliament; if a majority was not reached on the first ballot, the two leaders faced a run-off at the second. David Hamer has argued that the Liberal Party brought this measure as a way of dealing with the diversity of their party, and as a way of organising candidates after loss of Seddon's leadership: the second ballot allowed the Liberals to run several candidates at the first without splitting the vote. ${ }^{103}$ It also protected the Liberals against the rise of the Labour Party. On the other hand, it unpopular with farmers, who did not find it easy to organise another trip to the polling booth if a first-ballot majority did not occur. ${ }^{104}$

Massey's opposition to the Second Ballot Act was not mere political manipulation, and found some support even among the Liberals. However, before coming to power, Massey had expressed his support for proportional representation, and promised that while he would repeal the Second Ballot Act, he would find some system for proportional representation with which to replace it. However, after becoming Prime Minister, he introduced its repeal without explanation, and without any attempt to find a new method for ensuring majority or proportional representation. In the face of Joseph Ward's claims that he was making a "barefaced attempt to try and create minority representation" in the knowledge that the rising support for Labour candidates was splitting the opposition vote, Massey offered no explanation, other than that his "faith in proportional representation" had been "somewhat shaken". ${ }^{105}$ Massey knew very well that he would benefit, in a First Pass the Post System, from the rising Labour movement; after holding onto the government benches by the slimmest of majorities in 1914, Reform's share of the vote fell in 1919, yet their majority in the House of Representatives increased, and they got forty-seven seats of the eighty seats in spite of winning only thirty-seven per cent of votes. ${ }^{106}$ If Massey's appeal to protestant bigotry is going to be defended as an attempt to hold on to power rather than punish Catholics, then it has to be considered together with his changes to the electoral system, and presents an anti-democratic attitude.

\footnotetext{
103 David Hamer, "The Second Ballot: A New Zealand Electoral Experiment," New Zealand Journal of History 21, 2 (1987), p.99-101, 103-4.

104 Hamer, "The Second Ballot," p.104.

105 NZPD 1913, vol.166, p.628, 634; vol.167, p.204. The Second Ballot Act 1908 was repealed by the Legislature Amendment Act 1913, s.4.

${ }^{106}$ Bassett, p.248.
} 
The other major criticism of Massey has been that he was an enemy of the working man, a critique advanced by many who have written about the 1912-3 industrial conflict. Erik Olssen in Red Feds and Richard Hill in The Iron Hand in the Velvet Glove portrayed the Prime Minister's use of violence to end the 1913 strike as excessive and unnecessary, particularly his use of special constables recruited by the military and allowed to baton protestors from horseback. ${ }^{107}$ Hill quoted as evidence the statement by Col. Heard, mentioned previously in this chapter, that the Reform government had a policy of allowing the strike to escalate to the point where a violent response seemed justified, rather than intervening earlier. Fairburn, in an essay in Melanie Nolan's Revolution, criticised Hill for coming to this conclusion, saying that as Heard repeatedly stated that Massey and the Police Commissioner had no plan to deal with the strike, they could not have had a plan to use force to crush it. But Fairburn misread Heard's account, as Heard stated that the absence of the plan was the policy. ${ }^{108}$ In his introduction to A Great New Zealand Prime Minister?, Erik Olssen also criticised the anti-Massey tradition he himself had helped construct around the strike, stating that the revolutionary left "played into" Massey's hands by disregarding industrial agreements, and represented a form of labour elitism "alien to New Zealand". ${ }^{109}$ Yet this line strangely ignored the evidence in Olssen's own earlier research, where he demonstrated that, contrary to Massey's belief that the strikes were brought to New Zealand by foreign union leaders egging their followers on, in fact these Australian-born union leaders were sometimes more willing to compromise than the rank-and-file. On November 2 1913, "Red Fed" leaders finally succeeded, after weeks of trying, to get waterside workers to agree to a compromise, only to find that the government now said it was too late, and withdrew the compromise. ${ }^{110}$ In April 1917, when miners were striking over conscription, the arrest of union leaders on sedition charges, and pay, James Allen managed to get their leaders to back down on conscription and the release of arrested seditionists in return for concessions over pay, but rank-and-file members initially rejected

\footnotetext{
${ }^{107}$ Richard S. Hill, The Iron Hand in the Velvet Glove (Wellington: Dunmore Press, 1995), p.307 ; Erik Olssen, The Red Feds: Revolutionary Industrial Unionism and the New Zealand Federation of Labour 1908-14 (Oxford University Press: Auckland, 1988).

108 Miles Fairburn, “Interpreting 1913: What Are the Important Questions?”, in Melanie Nolan ed. Revolution: The 1913 Great Strike in New Zealand (Christchurch: Canterbury University Press, 2005), p.65.

109 Olssen, "Towards a Reassessment of WF Massey: One of New Zealand's Greatest Prime Ministers (Arguably)," p.18.

${ }^{110}$ Olssen, The Red Feds, p.181-2, 184-6.
} 
the compromise, and it took their supposedly agitationist leaders several more days to get the miners to call off the strike. ${ }^{111}$

Those who have sought to revise Massey's image for the better have not been able to successfully deal with his anti-Catholicism, nor his violence in breaking strikes. The strongest argument they have made has been that the governments he led made genuine efforts to improve the wellbeing of working-class New Zealanders: that he reduced class and religious divisions by providing greater security and the opportunity for upward mobility by helping New Zealanders achieve home ownership and secondary schooling. Miles Fairburn provided evidence that over the course of Reform's period in government, the proportion of wageearning householders who owned their own home increased from one-third to over onehalf, and that the proportion of primary school leavers who went on to secondary schooling similarly increased from one-third to over one-half. ${ }^{112}$ Particularly important to the hearts of New Zealanders was the idea that every man should be his own landlord; Reform facilitated this by expanding the Liberals' Advances to Workers Act, increasing the amount of funding available to home buyers to 95 per cent of the value of the purchased home.

While the 1915 Discharged Soldiers Settlement Act has been roundly criticised for the fact that it put many soldiers onto poor quality farms of inflated value, leading to debt and suffering, Fairburn pointed out that it was much more successful in settling men on urban and suburban properties. ${ }^{113}$ While Fairburn noted that the debt the state took on to fund these advances became troublesome during the Depression, nevertheless his point was that providing men with a sense of security - even if they were only replacing a rent with a mortgage which could lead to default - did ultimately reduce class-based animosity. ${ }^{114}$ This piece of Massey revisionism is key to the argument of my thesis: that a party who reached power on a platform of opposition to the encroaching power of the state increased its size and reach in ways never before thought possible. That they did so in ways which helped New Zealand serve Britain in its war effort is both unsurprising, and the basis of my hypothesis that the expansion of the state was driven by Imperialism, not a desire to

\footnotetext{
111 James Allen to William Massey, 7 December 1916; 26 April 1917 (NA: Record Group: Allen1, Box:9, Item ID: R22319675).

${ }^{112}$ Miles Fairburn, "The Farmers Take Over," in Keith Sinclair ed. The Oxford Illustrated History of New Zealand $2^{\text {nd }}$ ed. (Auckland: Oxford University Press, 1996), p.205-6.

113 Ibid.

${ }^{114}$ Fairburn, "The Farmers Take Over," p.187, 189-90, 206-9.
} 
improve welfare. Yet if Fairburn is correct, Reform expanded the reach of the state for the good of all New Zealanders. Before turning to address Massey and his followers' views of the state and the British Empire, it is important to note that many of the achievements Fairburn used to demonstrate Massey's lack of hostility to the working classes were the work not of Reform alone, but of coalition governments: the wartime National Coalition of 1915-9, and the minority Reform government from 1922 until Massey's death, which relied on the support of the votes of Independent members for its survival. Fairburn is correct in stating that education and housing provision improved under Reform, but neglected the importance of coalition partners in forcing Massey and his party to make this so.

\section{Joseph Ward and the National Coalition}

Massey's main political opponent from the death of Seddon until his own two decades later was always Joseph Ward. Massey and Ward were both born in 1856, and both born to Irish parents, but on different sides of the sectarian divide. They were both wide readers in spite of lacking higher education. Neither had much respect for their opponent, yet they formed a coalition National Government on the first anniversary of the war, bringing about, in the words of Michael Bassett, "four years of political partnership involving unparalleled physical closeness without personal warmth or much mutual respect". ${ }^{115}$

Ward was a post office message boy and store clerk before setting out on his own in his early twenties as a Southland merchant, trading in primary produce and farm supplies; at the same time he entered local body politics, serving on the Harbour Board before becoming Mayor of Bluff at the age of twenty-five. Two years later, he married the daughter of his mother's rival publican. He entered parliament in 1887 and became Postmaster General in the first Liberal administration four years later, reducing the cost of toll calls and telegrams, much to the benefit of his business and the country as a whole. ${ }^{116}$ Although young and relatively unknown, he was the most successful businessman in cabinet, and rose to become Treasurer after two years, when Seddon became Premier. ${ }^{117}$ Four years later, his

\footnotetext{
115 Bassett, p.244.

${ }^{116}$ Bassett, p.12, 16, 30, 32.

117 Bassett, p.43.
} 
mixing of public office and private business interests, and the heavy debt he owed to the Bank of New Zealand on its rescue by the State, forced him into bankruptcy and out of office, but after resigning his seat he was re-elected with an increased majority, and spent the last year of the nineteenth century rearranging his business interests to return to prosperity. ${ }^{118}$ From December 1899, he was Seddon's "deputy and heir apparent". ${ }^{119}$ After five years successfully managing the country's growing railways and communications, Ward became Prime Minister, and held the office for six years. But, as we have already seen, these years saw the diversity of the Liberals move from being a strength to a liability, and he ultimately failed to control a caucus rent by the land question. After some time off from public life and the leadership of the Liberals during 1912-3, he spent three years as leader of the opposition, engaging in partisan attacks against Reform whenever possible, particularly over the repeal of the Second Ballot Act.

While he did much to develop the country's infrastructure as a Minister under Seddon, he was not a successful leader, and Bassett stated that "Any reasonable commentator would have to conclude that his political career went on far too long," and that "aspects of it bordered on farce". ${ }^{120}$ According to Leslie Lipson, "Ward's personal limitation" - his lack of Seddon's broad populism - "contributed to the restriction of Liberal influence" and the fracturing of the Liberal-Labour alliance. ${ }^{121}$ The outbreak of war made his self-aggrandising, partisan approach to parliamentary debate impossible.

On 20 May 1915 the Liberal and Conservative parties in Britain formed a National Government, and straight away Reform and the Liberals faced pressure to follow suit, in one of the strongest example of New Zealand's wartime policy copying British policy for the sake, partly, of copying British policy: in a speech to the Empire Parliamentary Association at the British House of Commons in October 1916, Massey cited the fact that only New Zealand had copied Britain's move to a National coalition as evidence of the Dominion's loyalty. ${ }^{122}$ In contrast to the hundreds of pages of bitter debate on the Address in Reply the

\footnotetext{
${ }^{118}$ Bassett, p.57-85.

${ }^{119}$ Bassett, p.101.

120 Bassett, p.viii.

${ }^{121}$ Leslie Lipson, The Politics of Equality: New Zealand's Adventures in Democracy $2^{\text {nd }}$ edn. (Wellington: Victoria University Press, 2011), p.281.

122 W.F. Massey, "The Call of Empire: Speeches and Interviews in Great Britain, 1916-7," (AT: Micro-MS-0843), p.20.
} 
previous year, the Speech from the Throne of 1915 received a brief acknowledgement from each party, consisting of two maiden speeches totalling twelve pages, before the House returned to business. ${ }^{123}$ On 25 June, after Massey thanked Ward for allowing legislation to pass without opposition or debate in order to ensure the smooth administration of the war effort, Ward responded that while the Opposition could not relieve the Government of "responsibility for their policy" or even "share the responsibility with them," they would do all in their power to help out in matters concerning the war. ${ }^{124}$ Yet a mere four days later, Massey announced that he would like to begin coalition negotiations. That he had not mentioned the matter to Ward before raising it in parliament demonstrated the difficulty they would face in reaching an accord. ${ }^{125}$

Massey offered three, then four, out of nine cabinet seats to the Liberals; Ward struck a hard bargain, insisting on equal representation - and a shared premiership - in spite of the fact that the Labour members' refusal to join meant four out of nine was a fair representation of the seats in the House. After negotiations collapsed and the Governor stepped in, Massey accepted that each party would hold six cabinet seats, with the Reformaligned Representative for the Native Race Maui Pomare holding the balance; Ward would not get to share the premiership, though he would get the Finance portfolio, and regarded himself as Massey's equal in all but name. ${ }^{126}$ The coalition was announced on the anniversary of the declaration of war.

Bassett has argued that the ball was in Ward's court: Massey's majority of one made governance difficult, and Ward could have forced him to continue until circumstances necessitated an election, even though this could have made the Liberals appear disloyal and reduced their share of seats. Bruce Farland has argued against that Massey was in the stronger position, and that he could easily have called Ward's bluff. Both ultimately agree that, although Massey gave away a lot of power, Ward's reputation suffered in the long run - whereas Massey increased his party's majority at the next election (which was twice delayed due to the war, finally taking place in late 1919), Ward not only failed to defeat

\footnotetext{
${ }^{123}$ NZPD 1915, vol.172, p.58-69.

124 NZPD 1915, vol.172, p.19.

125 NZPD 1915, vol.172, p.57.

${ }^{126}$ NZPD 1915, vol.172, p.223-4; Kay, p.92-107.
} 
Reform but failed to win his own seat. ${ }^{127}$ When the two leaders visited Britain to take part in the Imperial War Cabinet in early 1917, Ward's insistence on attending all meetings as Massey's "equal" was a constant source of irritation to the Imperial authorities, who wanted intimate meetings of the Prime Ministers alone, but were forced by Ward's vanity to accept two members from each Dominion. ${ }^{128}$ While such actions do confirm Bassett's portrait of Ward as an increasingly absurd political leader, his presence at the cabinet table ensured the Government made much greater attempts to tax war profits and control the rising cost of living than they would otherwise have done.

After Ward, the Liberal politician who plays the largest role in this story is William Donald Stuart MacDonald, a Poverty Bay sheep farmer who started out as a "swagman" and rose to cabinet rank with no more than a year's schooling. ${ }^{129}$ MacDonald worked closely with James Allen in his capacity of Minister of Mines to resolve the miners' strikes, but was probably most influential as head of the Board of Trade during the periods when Massey was overseas. James Allen, in his second report to Massey after the latter's departure for London, Allen expressed doubts about MacDonald, saying the latter and his Board meant well but were susceptible to "outside influences", presumably meaning pressure from the political left. He later criticised MacDonald's alleged tendency to take "the easy road" and bow to pressure to fix prices, although expressed no disagreement with the actual decisions reached. ${ }^{130}$ During the two periods when MacDonald headed the Board of Trade, he was able to steer it in a more interventionist direction than had Massey, and promoted pricefixing policies which did not always meet the Prime Minister's approval, a fact which led to acrimonious debate once the coalition collapsed: neither Massey nor MacDonald were willing to accept full responsibility for the controversial butter-fat levy, with MacDonald saying it had Massey's approval, and Massey saying it had been imposed essentially behind his back. ${ }^{131}$ A year after this dispute, having replaced Ward as Leader of the Opposition,

\footnotetext{
${ }^{127}$ NZPD 1915, vol.172; Bruce Farland, Farmer Bill : William Ferguson Massey and the Reform Party (Wellington: Bruce Farland, 2008), p.220-1. The Reform Party actually suggested a continuing merger, only to be rebuffed by the Liberals whom they then trounced at the polls - with the benefit, of course, of vote-splitting between Labour and the Liberals.

128 Bassett, p.235-6.

129 Poverty Bay Herald, 1 September 1920, p.2-3, 5.

130 James Allen to William Massey, 11 September 1916; 8 November 1916 (NA: Record Group: Allen1, Box:9, Item ID: R22319675).

${ }^{131}$ NZPD 1919, vol.185, p.1415-22.
} 
MacDonald died in office, allegedly from exhaustion stemming from his sleepless during the war.

Another Liberal member of cabinet, the newspaper proprietor George Russell, exerted his personality largely by feuding with his conservative opponents and disobeying his own party leader. Although his independence led Seddon to drive Russell from parliament, he was promoted to cabinet in Thomas Mackenzie's short-lived 1912 ministry and again in the National Government as Minister of Internal Affairs and Public Health. Soon after Massey and Ward left the country in 1916, Allen was writing to his leader that Russell was not "playing the game" by publicly criticising cabinet decisions - in the first instance, regarding the proposed site of Auckland University, Allen noted that he actually agreed with Russell's criticisms, but that Ministers were "bound to be loyal to the cabinet decision". ${ }^{132}$ After he sat Russell down for a chat, Allen was able to report that he had become "quite reasonable" - but less than three weeks later, he found Russell "difficult to understand" as he was largely absent from Wellington without notifying the Acting Prime Minister, who suspected Russell was "out to form a party of his own" and was "disloyal" not just to cabinet, "but to his own leader also." 133

By the end of the year, Allen reported that the threatened strikes against conscription had brought cabinet to work together, but in mid-1917 he once again had to report that Russell was "behaving very badly" and had "not been playing the game" by publicly leading opposition to some cabinet actions. ${ }^{134}$ These complaints demonstrate that the diversity of the Liberal caucus, stemming from the party's ambition to represent every New Zealander, which had caused so much trouble for Ward and led to their fall from office, not only remained throughout the war, but became a problem for the Reform-dominated National Government; Reform members, used to tighter party discipline made possible by appealing to a smaller, more united section of the electorate, now had to deal with the independence Liberal politicians expected to enjoy. After the death of the Liberal Justice Minister Robert McNab in 1917, Ward was set to appoint the renowned legal expert John Findlay to take his

\footnotetext{
132 James Allen to William Massey, 11 September 1916 (NA: Record Group: Allen1, Box:9, Item ID: R22319675).

${ }^{133}$ James Allen to William Massey, 11 October 1916; 28 October 1916; 8 November 1916 (NA: Record Group: Allen1, Box:9, Item ID: R22319675).

134 James Allen to William Massey, 22 November 1916; 19 December 1916; 12 May 1917; 9 June 1917 (NA:

Record Group: Allen1, Box:9, Item ID: R22319675).
} 
place at the cabinet table, but was thwarted by the ambitions of Hanan and Russell, who didn't want Findlay as a potential future rival for the Liberal leadership. ${ }^{135}$ Such internal posturing would have been unthinkable in Massey's party. Russell's career survived the war but took a final, fatal hit when the 1919 Influenza Epidemic Commission criticised the Minister of Public Health for failing to quarantine the Niagra (which was bringing Massey and Ward back to the country but also carried the virus), and for alleged maladministration in response to the epidemic's spread; his efforts in this regard have subsequently come to be appreciated, and he is now seen as having been made a "convenient scapegoat for a bitter and bereaved public." 136

\section{From the Only Official Opposition to a united Labour Party}

Besides the internal divisions of the Liberals which caused headaches for Reform, the National Government was also burdened by a policy of not advancing legislation which did not receive a consensus of support. ${ }^{137}$ This handicap nevertheless ensured the wartime government could claim to represent the will of the broad New Zealand community, something the narrow Reform caucus could never have genuinely asserted on their own. Had Labour members also agreed to join the coalition, it could have been said to truly represent all of the community - but given the events of November 1913, Labour members would have known that such a government would have been unworkable, as Herdman's comments on not wanting to share a parliament with them later confirmed. Labour Members of the House of Representatives also recognised that parliament needed an opposition, as the Liberals had abrogated this responsibility. Being put in the position of the only official opposition created unity among a divided Labour caucus: at the time of the National Government's formation, they were still split between the militant, pro-Federation of Labour, Social Democratic Party represented by Paddy Webb and James McCombs, and the more moderate United Labour Party of Alfred Hindmarsh, Andrew Walker and Bill Veitch, with John Payne standing as an Independent Labour man; J.T. Paul represented

\footnotetext{
${ }^{135}$ Bassett, p.238.

${ }^{136}$ AJHR 1919, H-31A, p.22, 27; Geoffrey W. Rice, "Russell, George Warren," in Dictionary of New Zealand Biography, Te Ara - the Encyclopedia of New Zealand, updated 30-Oct-2012, URL: http://www.TeAra.govt.nz/en/biographies/2r31/russell-george-warren.

${ }^{137}$ Kay, p.104-5.
} 
Labour in the Legislative Council. ${ }^{138}$ The appearance of the Military Service Act in the winter of 1916 finally brought these disparate groups together, and in July they formed the New Zealand Labour Party which remains to this day. ${ }^{139}$ By the end of 1918 , Webb (the only Member of Parliament who was single and of military age) had been imprisoned for refusing conscription into the military, and Hindmarsh had passed away during the influenza epidemic, but Labour's numbers increased with the success in three by-elections that year of Harry Holland, Robert Semple and Peter Fraser, all from the militant wing of the party. Holland also became party chairman in August 1919. ${ }^{140}$ Meanwhile Webb, as an illegal objector to military service, was deprived of the right to vote or stand for office for ten years after the war's end by the Expeditionary Forces Amendment Act 1918.

Formerly editor of the Maoriland Worker, Holland was outspoken in his support for conscientious objectors to military conscription. He brought a new intensity to Labour politics, and a greater ability than his fellow party members to challenge the government on points of law. However, his biographers have described him as "inflexible", "aggressive", "impatient" and "uncompromising", with a "penchant for arousing antagonism." 141 In spite of their opposition to conscription, Labour members rarely criticised - at least in public the fact that New Zealand participated in the war, and like Reform and Liberal politicians, Holland and Hindmarsh had sons at the front, while Semple's brother died in the conflict. ${ }^{142}$

\section{Duty to the State and the Duty of the State}

As I noted in my discussion of W. J. Gardner's work on Massey, the Prime Minister promoted individualism against socialist government, but demanded absolute loyalty from his followers. This contradiction was in fact central not just to the leader's personality, but to

\footnotetext{
${ }^{138}$ Barry Gustafson, Labour's Path to Political Independence: The Origins and Establishment of the New Zealand Labour Party 1900-19 (Auckland: Auckland University Press, 1980), p.89, 158, 160, 164, 168-9.

139 Gustafson, Labour's Path to Political Independence, p.91-4; Baker, p.153-4.

${ }^{140}$ P.J. O'Farrell, Harry Holland: Militant Socialist (Canberra: Australian National University, 1964), p.103; Gustafson, Labour's Path to Political Independence, p.132-6. For Webb's arrest and imprisonment, see H.E. Holland, Armageddon or Calvary: The Conscientious Objectors of New Zealand and "The Process of their Conversion" (Wellington: H.E. Holland, 1919), p.109-114; Len Richardson, "Webb, Patrick Charles," in Dictionary of New Zealand Biography, Te Ara - the Encyclopedia of New Zealand, updated 1-Apr-2014, URL: http://www.TeAra.govt.nz/en/biographies/3w5/webb-patrick-charles. ${ }^{141}$ O'Farrell, p.1, 66, 103; Gustafson, Labour's Path to Political Independence, p.137.

${ }^{142}$ Gustafson, Labour's Path to Political Independence, p.112.
} 
the actions of the Government during the First World War: a war supposedly fought to defend the British tradition of liberty, but which was used by politicians to erode liberties and demand physical and financial services on a scale never previously imagined. This tension between the fight for liberty and the need to restrict liberty in order to fight was played out in parliamentary debates over the nature of duty, and in statements from Ministers setting out the demands of Empire.

Speaking to English audiences during his visits Home as a wartime politician, Massey stressed that New Zealand was fighting because of her duty to the Empire: "where Imperial matters were concerned," New Zealanders would "never hesitate or quibble over details". He and Ward had not visited Britain to offer criticism, but "to show a united and determined front to the enemy", and that only after victory had been reached would British citizens from the far corners of the Empire come to settle their differences. ${ }^{143}$ In the meantime, they would "stand fast for the honour of the race, the glory of the Flag, and the welfare of humanity"; this would make the Empire "stronger, grander, more firmly bound together, working more in unison than ever." 144 Just as the war taught the parts of the Empire their duty to the centre, so it taught the individual his duty to the Crown:

"This war, awful as it is, will not have been an unmixed evil if it teaches us the lesson of preparedness and, as individuals, teaches us our duty to the State teaches us that, in a time of crisis, every man's services and every man's property belong to the country if his country requires them". ${ }^{145}$

Yet he also "got the impression, correctly or otherwise, that many of the political leaders in Britain" did not "realise the present and future importance of the Dominions to the Empire". He insisted that he was voicing this concern "as an Imperialist" committed, above all else, to preserving the integrity of the Empire, and not as a colonial leader out to promote his country's own interests. ${ }^{146}$ Nevertheless, he would go on to repeat the fact that more had to be done to reward the Dominions, and to allow them a say in Imperial matters: "something must be done in addition to the sentimental ties which now keep the empire together,

\footnotetext{
${ }^{143}$ Massey, p.20-1.

144 Massey, p.38, 76.

145 Massey, p.62.

146 Massey, p.55.
} 
though I am glad to acknowledge these latter have stood one of the severest tests it is possible to apply - the test of the present war." 147 This "something" partly meant Imperial trade preference, but it also meant some form of consultation on policy matters:

"The Dominions have ceased to be dependents. They must now be regarded as partners in the firm of John Bull and Co., even if for a time they take their places as junior partners for a time. I think a great opportunity to give the Dominions a voice in Imperial affairs was missed at the commencement of the war in not taking representatives from them into the Imperial Cabinet." 148

After expressing his support for an Imperial Parliament to consider matters relating to foreign policy and the Empire as a whole (while leaving domestic matters to the parliaments of each constituent state), Massey conceded that such a proposal was unlikely to come to fruition in the near future, so he instead suggested a periodic Imperial Council, essentially a continuation of the meetings he and Ward were attending into the era of peace. Achieving such an end required a greater role for the State in coordinating the furtherance of the Imperial ideal:

"Tell the people, tell all your thousands of readers, that the British Empire after the war is going to be stronger, grander, more firmly bound together, working more in unison than ever. We are all, each part of it, going to help the others. We are all going to produce, to manufacture goods, to man our ships, to keep up the Imperial Army and Navy, in a wonderful bond such as the world has never yet known or seen. In a word, the whole British Empire is to be organised and managed as a thoroughly noble and democratic band of brothers. I hope in every sense we shall be one family of the very finest and best kind." 149

While careful to make sure his speeches emphasised loyalty and duty to Empire as the foundation of future unity, Massey was able to utilise these visits to promote the interests of the Dominion, albeit in the name of shoring up the future success of the British Imperial project. Speaking to New Zealand's House of Representatives on the surrender of Austria,

\footnotetext{
147 Massey, p.64.

148 Massey, p.64, 69.

${ }^{149}$ Massey, p.76.
} 
Massey even suggested adding a new cross to the Union Jack, representing the overseas Dominions. ${ }^{150}$

In this House, Massey was no less eager to assert that duty to the Empire came before the Empire's duty to the Dominions, and that the duty of the individual to the state trumped the duty of the state to the individual - in stark contrast to his peacetime belief that the Government owed farmers more than the farmers owed Government:

"The policy of the National Government is this, and has been all the time, and it has been the policy of New Zealand ever since the war commenced: to do our duty to the Empire and to keep the country prosperous so far as it was possible for us to do so." 151

Speaking in favour of conscription, Massey stated it to be "right that the State should be entitled, for the purposes of its own defence, to the service of every male", that "the State has a claim and a right to the services of every individual in the community", and that this was perfectly "democratic".When Labour member James McCombs interjected "Has the State no duties?" he replied that the State had its duties, and would do its duty, then left it at that. ${ }^{152}$

On the question of whether the individual's duty to the State allowed the State to compell men to risk their lives in its service, three members of the House of Representatives and three members of the Legislative Council gave the simple answer that the very foundation of politics - indeed, of life itself - was compulsion: Reform member Charles Wilkinson asked "if the voluntary system is going to be good enough for defence, is it good enough to collect taxes upon?"153 Liberal member John Hornsby put it rather poetically: "Every man's life spells compulsion from the cradle to the grave. We are not consulted about coming into this world, and certainly we are not consulted about going out of it." ${ }^{154}$ Similarly, Reformist William Nosworthy noted that citizens had "conscription, or compulsion, in every phase of our democratic existence" - in schooling and in public health, men were compelled to obey

\footnotetext{
150 NZPD 1918, vol.183, p.186-7.

151 NZPD 1916, vol.175, p.614.

152 NZPD 1916, vol.175, p.619, 758.

153 NZPD 1916, vol.175, p.506.

${ }^{154}$ NZPD 1916, vol.175, p.595.
} 
the law, and the "greatest thing" they could be compelled to do was to fight for their "hearths and homes" and for their "grand old flag." 155 Similarly, Legislative Councillors Moore, Beehan and MacGibbon stated that all "freedoms and liberties" were guarded by "compulsion and restriction", without which there would be no community; that men had "compulsion from the cradle to the grave", without which there would be no law; that "compulsion" simply meant "living under a regime of law and order". ${ }^{156}$ The way these arguments were framed suggest that those advancing them would vote for any form of compulsion suggested by any member of parliament, which was not the case: what they demonstrate, then, is that faced with the demand to support the military needs of the Empire, they were willing to embrace the rhetoric of duty to the state above all else.

Francis Bell used such rhetoric to criticise another member for saying the Dominion had sent enough men:

"if the measure of our duty is to be to find out what is just enough; if we are to do no more than just enough; if we are to test our effort, and our offer, and our service, by what others may deem to be the quality and the limit of theirs, then I am not fit, nor are my colleagues fit, to define that measure." 157

Other members of the coalition took the same attitude, asserting that "every man's first duty" was "to the State"; that in the unique situation they faced their "duty" and their "patriotism" to their country "should come first"; and that it was appropriate "for the State to step in" and tell each man when the time had come to do perform this duty. ${ }^{158}$

Others, however, acknowledged that men with families had multiple duties. While insisting that New Zealand's duty could not restricted to what was "just enough", Francis Bell conceded that married men, "with many obligations and many duties," might want to go and fight, but in some cases must not. ${ }^{159}$ David Buddo, the Liberal Member for Kaiapoi, stated that such men wished "to do their duty in helping to defend the Empire," but "looked

\footnotetext{
155 NZPD 1916, vol.175, p.606.

156 NZPD 1916, vol.175, p.885; vol.176, p.13, 14.

157 NZPD 1916, vol.176, p.17.

158 NZPD 1916, vol.175: Harry Ell, Liberal Member for Christchurch South, p.546; Capt. Hine, Reform Member for Stratford, p.568; R. W. Smith, Liberal Member for Waimarino, p.770.

${ }^{159}$ NZPD 1916, vol.175, p.873.
} 
upon it as the duty of the State to see that their dependants were properly looked after while they fought the country's battles." 160

While Bell and Buddo weighed up the all important duty of the individual to the Crown with the State's duty to provide for the individual to allow him to fulfil his obligations, Labour members responded to the call for conscription by stressing the duty of the State to the individual and of the individual to his dependents as paramount. Paddy Webb stated this most clearly:

"Sir, I entirely disagree with the honourable member for Christchurch South in his statement that a man's first duty is to the State. I disagree entirely with this sentiment. I hold that a man's first duty is to his own father and mother; and when the State steps in between the parents and the individual the State must say in no unmistakable way that the parents of the young will be protected." 161

Responding to arguments in favour of conscription that appealed to the example of Abraham Lincoln's draft, Alfred Hindmarsh argued that Lincoln imposed this draft only after he had set out a "charter" of the duties of the state and of the wealthy to the people and, especially, to the soldiers:

I would like to ask you, Sir, in as cool a way as I can, what are the obligations of the State to the individual, and what are the obligations of the individual to the State? Now, what is the duty of our young men to the State, and what is the duty of the State to the young men? Are the obligations to be all on one side or are they to be mutual - are they to be reciprocal? That is what I want to know. Sir, I hold on the one side it is the duty of men, if necessary, to die for the State; and I do not object to conscription, because there may be a time when conscription is absolutely necessary. But, while it is the duty of the individual to serve the State in this way, I say the State has a duty to the individual. We have been waiting for that obligation to be defined, and it has never been defined by the Prime Minister." 162

\footnotetext{
${ }^{160}$ NZPD 1916, vol.175, p.623.

${ }^{161}$ NZPD 1916, vol.175, p.565.

${ }^{162}$ NZPD 1916, vol.175, p.542.
} 
Later that same evening, Hindmarsh returned to this theme, feeling that his question had been greeted with a wall of silence:

"I want to ask again this evening, is the State under any obligation to the individual that either by pressure or by conscription it makes go to the front? Sir, I say it is under an obligation. Surely it must be under an obligation, because if it is not under an obligation there is no such thing as any State. I say, if it is under an obligation to the individual, it should recognize that obligation, and it should say to the soldier, "We have prevented you, by your service to the Empire, from following your usual occupation; we have deprived your family by making you work at the most dangerous work you can follow; and we have deprived your family of the money that by your work you would have provided them." The State should recognize that obligation, and pay a reasonable amount to the soldier." 163

Weighing up the obligations of the subject and the obligations of the State, Hindmarsh had presented an argument for proper compensation for services rendered. His colleague James McCombs agreed:

"We have heard a great deal about the duty of the individual to the State: has the State no duty to the individual? Is it not up to the State to reward the individual for services rendered?" 164

Refusing to recognise the mutual obligation involved made "young men not the willing helpers of the State in time of danger, but the slaves of the State both in peace and in war." 165 McCombs did not stop there, but took this weighing-up of duties in another direction: not only compensation, but total organisation was required if men were going to be pushed into the front line:

\footnotetext{
${ }_{163}$ NZPD 1916, vol.175, p.578-9.

164 NZPD 1916, vol.175, p.502.

165 NZPD 1916, vol.175, p.594.
} 
"We stand for national service and the marshalling of all our resources; and if we marshall all our resources, and make proper provision for the soldier and his dependants, we can send volunteers." 166

This argument meant the conscription, not just of flesh, but of wealth.

\section{Socialism for the Empire?}

Throughout the debates over the Military Service Act, those who opposed the Act - and even many of those who gave it their support - argued that if men were to be compelled and organised to fight, then the whole resources of the country should be organised and wealth conscripted as well. While the laws of supply and demand might govern prices in peacetime, by committing to war the State had already interfered with these laws, and so had a duty to make sure this interference did not starve the families of those paying the ultimate price to defend their home.

For some, the absence of conscription of wealth was reason to withhold support for the conscription of men. George Witty argued,

"If you are going to have equality of sacrifice right through, then those men who are will-to-do to-day should be allowed only the same amount of money as is given to the soldiers fighting at the front, and the surplus should be taken by the State for the benefit of the dependants and wounded [...] If you conscript men, then you must conscript wealth." 167

For Paddy Webb, conscription of wealth meant that "just as you want every available man, we hold that the State that says every available man is required in order to prosecute this war to a successful issue ought to say that every available shilling is required." 168 Alfred Hindmarsh pointed to the example of Britain, which he said had done much more in this direction than its loyal Dominion, by taxing incomes and war profits and controlling rents. ${ }^{169}$ The Liberal member W T Jennings noted that Britain had taken over the munitions factories

\footnotetext{
166 NZPD 1916, vol.175, p.502.

${ }^{167}$ NZPD 1916, vol.175, p.495-6.

168 NZPD 1916, vol.175, p.564.

${ }^{169}$ NZPD 1916, vol.175, p.578.
} 
which hadn't been paying adequate wages, and argued that there should be no private ownership of industries producing material for military purposes during the war. ${ }^{170}$

Other members argued that those promoting the conscription of wealth had not properly defined what they meant, so that either conscription of wealth was already in place, via taxation, or that it was simply a euphemism for full-scale nationalization of private property. David Buddo took this view:

"Now, I want to say, as a farmer, that I have heard during the present debate no end of reference to the conscription of wealth. To my mind, that thing is absolutely impracticable without dishonesty and confiscation and an upsetting of the whole business necessities of the Dominion. We must bear in mind that industries have to be kept going, and it is quite possible that if you were to conscript wealth there would be nothing left to employ the workers with. The present system of taxing war profits appears to me to be the honest one. The taxation can be increased wherever necessary, to the last turn of the screw. If you want to do extreme things of that sort it would be madness - financial madness." 171

Legislative Councillor Moore called the descriptions of the conscription of wealth "blissfully vague", and as such suggested that they were a mask for the confiscation of "all private property"; Moore argued that, anyway, "under compulsory taxation" the State had always enforced the conscription of wealth: "Whatever the Government requires for the good of the State if takes from the people. We do not volunteer the money for them." 172

George Russell stated that wealth could not be conscripted because wealth took the form of various sorts of property and shares as well as simple cash:

"How are we to conscript wealth? There is only one way to do it, and that is by the State exercising its sovereign power through Parliament and taking possession of everything in New Zealand. That will be conscription of wealth exactly the same as is meant by conscription of manhood. You take the entire

\footnotetext{
170 NZPD 1916, vol.175, p.592.

171 NZPD 1916, vol.175, p.622.

172 NZPD 1916, vol.175, p.888.
} 
man, and if the other course be taken you must take the whole of the wealth [...] Once begin the conscription of wealth, and where will it end? [...] underlying their statement that there shall be conscription of wealth comes the great bogey - the phantasm, I can call it nothing else, of the wildest socialism - and they wish to use the fact that New Zealand is defending itself against the German menace as a means of carrying on their propaganda in the direction of obtaining wild-cat socialism, under which there would be for twenty-four hours the distribution of everything amongst everybody, and at the end of twenty-four hours there would be just the same beginning once again, and the individualism of merit, of ability, of honesty, of sobriety, and of everything that makes a man would begin to assert itself the following day." ${ }^{173}$

Others supporters of the Government, and of conscription, were perfectly happy to add their voices to the calls for the conscription of wealth, believing that only total organisation of national resources could prosecute the war to a victorious conclusion. Liberal member T. W. Rhodes stated:

"The outstanding feature of the Bill is the indication of the intention of the Government to make use of every eligible man of military age as requirements demand. And I think we ought to go a little further than this, and organize the industries incidental to our requirements, and utilize men over military age, or men unfit for active service, in connection with the production of clothing, foodstuffs, and so forth." 174

Similarly, Reform member George Anderson stated that:

"Under the voluntary system it is quite impossible to have complete organization; and organization of the whole population and the resources of the country are obviously necessary when the Empire is at death-grips with a scientifically organized and unscrupulous nation like Germany." 175

\footnotetext{
173 NZPD 1916, vol.175, p.766.

${ }^{174}$ NZPD 1916, vol.175, p.589.

${ }^{175}$ NZPD 1916, vol.175, p.513
} 
Anderson's Reform colleague Edward Newman put it simply: "Not only the military Forces, but the whole industries of the country should be organized."176

The use of the term conscription of wealth - military wording used as an argument for statesocialism - allowed Labour leaders to promote their socialism as one-and-the-same with their loyalty to Empire. Defining socialism as "combined action for the good of the combined people of the state," John Payne asserted that "if it had not been for that socialism Great Britain's name was mud in the early stages of the war"; only by "socialistic methods" was she able to "provide for her munitions". ${ }^{177}$ J.T. Paul celebrated the death of "individualism" throughout the empire. ${ }^{178}$ Even Reform members began to accept the use of the term socialism to describe their interventionist methods: Francis Bell stated that "None of us are against socialism - to socialistic experiments" such as the Board of Trade; Massey, despised by many unions as a heavy-handed strike breaker, went so far as to say that while he was "not a State Socialist in the ordinary sense of the term", nevertheless he looked forward to the day when the steamships carrying New Zealand's exports would be in state hands. ${ }^{179}$ While the new consensus in favour of intervention meant the war allowed political leaders on the left to promote their long-held policy objectives as loyal, it also meant that their opponents could promote the imposition of regulations against strikes and work stoppages as similarly socialistic measures, now that Socialism and Imperialism could be used in the same breath.

William Ferguson Massey had led Reform to power as an anti-interventionist party, albeit one that accepted much of the Liberal's state apparatus as serving the needs of a growing community. The outbreak of war forced them to embrace intervention on a scale they had never foreseen, and many of these interventions lasted once the war was over. Some departments of state, such as public education, saw little noticeable change, although administrators did impose stricter rules ensuring loyalty to the Crown; others policies, particularly conscription and income tax, were predominantly novel and imposed on a grand scale. By examining economic, justice, and educational policies, we will see how Massey and his assistants used their control of the state to fight for the defence of the Empire, and how

\footnotetext{
176 NZPD 1916, vol.175, p.560.

177 NZPD 1915, vol.173, p.436.

178 NZPD 1915, vol.174, 807.

179 NZPD 1915, vol.174, p.806; NZPD 1916, vol.177, p.629.
} 
they simultaneously used this fight for the Empire to increase the role of the State in the lives of the people. The growth of the state was necessary to the defence of the Empire, which in turn drove a continual increase in the power of the state. 


\section{Education for National Life}

Midway through the First World War, New Zealand's Minister of Education, Josiah Hanan, wrote that "the extraordinary conditions and problems created by the war" necessitated a reorganisation of the country's system of education, as schooling - being the "direct reflection of national life" - was the most important means by which "national life" would be rejuvenated after the coming of peace.

While he believed the "type of manhood and womanhood" developed in the Dominion's schools had been "vindicated" by the people's response to the call to arms, nevertheless a "lack of system and control, an extreme deference to individual and local conditions" constituted a major weakness "in educational as in national affairs." The great crisis of the time required "coordination and economy of effort." 180 Over the course of the war, the Ministers of Education - James Allen in the Reform Ministry, Hanan in the National coalition - passed a number of measures which both tightened central control over education, and enforced outward devotion to imperial duty. Legislation barred "enemy aliens" from teaching while the war raged on, and, once it had come to an end, required every teacher to swear an oath of allegiance to the King. A new history and civics syllabus stressed a need to instil in pupils "love for their country ad pride in the achievements of the race throughout the Empire"; this teaching was to be accompanied by weekly flag-saluting ceremonies. ${ }^{181}$

These measures appear to confirm my hypothesis, that during the First World War the growing power of the central state and imperial loyalties enjoyed a mutually-constitutive relationship. Yet before jumping to conclusions, we must acknowledge that the legislation mentioned above was in some cases reluctantly imposed by politicians responding to intense anti-German public sentiment; and also that war-time economic realities and the loss of manpower eroded some elements of central control.

In October 1914, in the midst of the Dominion's efforts to arrange and send off its expeditionary forces, Education Minister James Allen brought to the House an Education Bill

\footnotetext{
${ }^{180}$ AJHR 1916, E-1A, p.1-2.

${ }^{181}$ New Zealand Gazette 1921, vol.II, p.1582-3.
} 
which two successive governments had been building up to for two years, ever since Josiah Hanan, in his long-coveted but short-lived first term as Education Minister, had initiated the Cohen Commission. ${ }^{182}$ The consequent bill was primarily, said Allen, a measure to increase salaries, to set up a central Council of Education and temporary District Councils as required, to centralise grading of teachers in order to ensure a nationwide transfer system ${ }^{183}$ at the hands of the central Department rather than local Boards, to remove employment of Inspectors from the Boards to the Department, and to reduce the number of Boards. ${ }^{184}$

The Act was, Allen and many subsequent speakers stated, the culminating legacy of the retiring Inspector-General George Hogben. The various different measures in the act all added up to the Reform Government continuing Liberal policy in the direction of centralising control and increasing expenditure. However, given the need for unity at a time of crisis, the government was unwilling to force any overly-divisive plans through; the most contentious aspect of the Bill - the abolition of several small Education Boards - was referred to a special Commission, due to Parliament's inability to reach agreement on the details. In these circumstances, "what should have been the culmination of Hogben's long reign fell short of his expectations." 185 Allen, a supporter of the Bibles in Schools movement, shelved his plans to introduce greater provision for religious instruction. When Hanan became Education Minister in 1915, under the wartime National Government, he was finally in a position to push education towards greater centralisation, yet his reforms were held back by the cabinet's requirement for absolute consensus, and a desire not to incur the expenditure of policy reform during the war.

Expenditure on education doubled between the start of the century and the outbreak of war, outpacing the growth of the state as a whole; while expenditure on education continued to grow substantially from 1914 to 1919, it lagged behind the growth of normal

\footnotetext{
182 J.L. Ewing, The Development of the New Zealand Primary School Curriculum 1877-1970 (Wellington: New Zealand Council for Educational Research, 1970), p.121; Gregory Lee, "Hanan, Josiah Alfred," in Dictionary of New Zealand Biography, updated 30 October 2012, URL:

http://www.TeAra.govt.nz/en/biographies/3h5/hanan-josiah-alfred; Herbert Roth, George Hogben, $A$

Biography (Christchurch: New Zealand Council for Educational Research, 1952), p.140, 143.

183 That is, a system to organise the transfer of teachers between schools.

${ }^{184}$ NZPD 1914, vol. 171 p.21-30; see also NZPD 1914, vol. 168, p.704-14.

185 Herbert Roth, "Hogben, George," in Dictionary of New Zealand Biography, updated 30 October 2012, URL: http://www.TeAra.govt.nz/en/biographies/2h44/hogben-george
} 
state expenditure by 44 per cent to 58 per cent. ${ }^{186}$ In spite of Hanan's description of Education as the key to a prosperous post-war world, it took a back seat for the duration of the conflict. Being the most ambitious Education Minister, policy-wise, since Charles Bowen (architect of the 1877 Act introducing free, secular and compulsory education), Hanan drew up a lengthy memorandum after a year in the job, setting out plans for increased central control, particularly over secondary education. He was able to extend control over the grading of teachers; he also introduce medical inspections and a dental service to primary schools, arguing that many of the volunteers rejected for military service due to poor health would have been able to fight had such policies been in place earlier. Yet many of his changes went unimplemented - partially because he lost his position on the return to an allReform ministry when peace arrived - and he felt compelled to deplore those who "cavil at the cost of education", arguing that the cost of war did not justify educational retrenchment: "There never has been a time when interest, patriotism, and honour alike may more justly be pleaded in support of a generous endeavour to remedy the deficiencies of our educational system. With the unexampled destruction of life and property entailed by the war, there will come an unexampled call to make the most of the brains and hands of the coming generation, whose task it will be to replace the loss." 187

\section{Centralisation, Differentiation and Social Efficiency}

Rev. William Habens, Inspector-General from the beginning of secular, free and compulsory Dominion-wide education in 1877 until his death in 1899 (and Director of Education from 1886), single-handedly crafted the curriculum for twenty-two years. His singular control at the centre was balanced by strong power in the regional Boards, who controlled the staffing and inspection of schools. The high schools, whose boards jealously guarded their independence from both the Education Boards and the Department, followed curricula set to meet requirements dictated by the Universities. David McKenzie has argued that "Habens had no choice but to write the first national school syllabus from his office in Wellington"

\footnotetext{
186 NZOYB 1920, p.330.

${ }^{187}$ AJHR 1916, E-1A, p.8-11; Ewing, p.154; Lee, "Hanan, Josiah Alfred"; Roger Openshaw, Greg Lee and Howard Lee, Challenging the Myths: Rethinking New Zealand's Educational History (Palmerston North: Dunmore Press, 1993), p.113, 133.
} 
because the Boards would not give him direct access to schools, and they also employed the Inspectors who reported to Habens. ${ }^{188}$ When he was succeeded by George Hogben, the new Inspector described himself as a "general without an army". ${ }^{189}$

As an Inspector for the North Canterbury Board in 1887 Hogben had advocated not just centralising the inspectors, as he later achieved, but abolishing the Boards altogether, saying they were "more or less extravagant." 190 Like Habens, Hogben was a non-conformist protestant; both got their experience of actual classroom teaching in Canterbury secondary schools. Habens had been a secretary to the Canterbury Board, Hogben an Inspector for the North Canterbury Board: thus both men had experience as teachers and local administrators. ${ }^{191}$ As headmaster of Timaru High School in the 1890s, Hogben had implemented some of the policies he recommended as Inspector - more vocational training and free places for bright students. ${ }^{192}$

One of Hogben's first acts as head of the Department of Education was to attend a conference on the primary school syllabus with representatives from the Boards. The conference repeated the calls made in Inspectors' reports since the 1880 s criticising parents' obsession with examination results, and pointed out the flaws inherent in having Inspectors come in to examine students to determine whether they could advance, without having observed the child's abilities for the rest of the year. ${ }^{193}$ Consequently in December 1899 Hogben abolished the requirement that all children be examined by the Inspector before advancing in grade, instead requiring head teachers to examine students up to Standard V. For Standard VI, the final year of primary school, the "proficiency" examinations, which not only determined eligibility to enter University but had also come to be seen by employers as a general certificate of quality, were still conducted by the Inspector, and Hogben would come to lament that the intention of the reforms had been skewed by the continuing obsession with this leaving exam. ${ }^{194}$ In 1900, Hogben's preference for greater vocational

\footnotetext{
188 David McKenzie, "Habens, William James," in Dictionary of New Zealand Biography, updated 30 October 2012, URL: http://www.TeAra.govt.nz/en/biographies/2h1/habens-william-james

${ }^{189}$ Report of the Commission on Education in New Zealand (Wellington: Government Printer, 1962), p.75.

190 AJHR 1887, I-8, p.27-9.

${ }^{191}$ McKenzie; Roth, "Hogben, George"; Roth, George Hogben, A Biography, p.70-2; Ewing, p.92.

192 Roth, George Hogben, A Biography, p.56-66.

${ }^{193}$ Ewing, p.94-7; AJHR 1880, H-II, p.16; 1882, E-1B, p.14; 1885, E-1B, p.12.

194 Ewing, p.98, 136.
} 
training instead of grade-based academic work was furthered by the Manual and Technical Instruction Act, which gave grants to establish technical classes. ${ }^{195}$

Hogben then moved to raise the remuneration of teachers, a necessary precursor to attracting quality educators: in 1901, to end regional discrimination, the salaries of teachers under all Boards were raised to the level of the highest-paid of their grade; Superannuation plans the following year stalled until 1905. 196 These salary-raising measures were accompanied by an extension of compulsory attendance at school: the School Attendance Act 1901 raised the leaving age to 14 and removed exemptions for sight- or hearingimpaired children; attendance also became compulsory for Maori living near Native Schools in 1894, for all school-age Maori in 1903, and for "defective" children in 1907. By 1914, according to UNESCO, the battle for compulsory education had been won. ${ }^{197}$

Besides increased expenditure and the extension of compulsory attendance, Hogben's inspectorship was characterised by moves to increase the power of the Department of Education and Inspector at the expense of the Boards, partially in order to further another of Hogben's aim - greater differentiation between schools and courses to make education more practical and vocational: "the subjects of the training should be chosen so that they have some bearing on the future life of the pupil." 198 One of the hallmarks of institutional centralisation around 1900 was classification - in the administration of hospitals, prisons, and schools, governments advocated increased classification of patients, inmates and pupils into differentiated groups, to allow tighter organisation and greater "efficiency". 199 This principle, while publicly accepted in hospitals and prisons, was often opposed in schools. Hogben argued for a centralised system with a large, differentiated syllabus; teachers and teachers' advocates, especially those speaking for sole-charge teachers of rural schools, wanted a centralised system but with a smaller, more manageable syllabus; many parents demanded a small, unified, academically-oriented syllabus and local control. Forcing parents

\footnotetext{
195 Roth, George Hogben, A Biography, p.91-3.

196 Roth, George Hogben, A Biography, p.94-8.

197 Colin McGeorge, "Childhood's Sole Serious Business," New Zealand Journal of History 40, 1 (2006) p.25, 323; Judith Simon and Linda Tuhiwai Smith ed., A Civilising Mission? Perceptions and Representations of the New Zealand Native Schools System (Auckland: Auckland University Press, 2001), p.9.

198 AJHR 1912, E-12, p.37.

${ }^{199}$ W. H. Oliver and Margaret Tennant, "Social Welfare: Social Justice or Social Efficiency?", New Zealand Journal of History, 13, no.1 (April 1979), p.26
} 
to accept classification of their children contrary to their parental aspirations was political suicide.

A second education conference in 1904 preceded a major syllabus overhaul in which Hogben made health, physical education, and moral training compulsory. Several historians have written that Hogben's enthusiasm for directing teachers to more hands-own, vocationally minded teaching "overestimated the abilities of mostly poorly trained teachers, many of whom found their new freedom bewildering"; some were unable to properly distinguish between the compulsory and recommended parts of the curriculum, failing to interpret it with the flexibility the Inspector had attempted. ${ }^{200}$ Hogben's "remedy" the following year "was gradually to replace the outdated pupil-teacher training system with a qualification gained from a training college in one of the four main centres." Yet while Hogben could attempt to continually direct policy towards practical education, ultimately parents predominantly demanded academic courses aimed towards white-collar employment for their children. "Even the district and technical high schools promoted by the department were forced by parent pressure to develop academic courses which copied the established secondary schools." 201 To facilitate Hogben's calls for greater power both to force secondary schools to accept poorer pupils and to have more Departmental input into the curriculum, in 1903 Richard Seddon introduced a Secondary Schools Act to force schools to accept free-place students. ${ }^{202}$

Hogben argued that instead of teaching students subjects which would have a bearing on their future rural lives, the District High Schools were too eager to give their students a "little Latin" and a little Euclid, all of it piecemeal and unretained. ${ }^{203}$ Hogben's attempts to dictate to rural parents the curriculum of their children were met with cries that it was unfair for rural children to miss out on the opportunities of the large schools, and his

\footnotetext{
200 Openshaw, Lee and Lee, p.99-100.

201 Openshaw, Lee and Lee, p.103-4; Roth, "Hogben, George."

202 Openshaw, Lee and Lee, p.104; Ian McLaren, "The Politics of Secondary Education in Victorian New Zealand," in Roger Openshaw and David McKenzie ed., Reinterpreting the Educational Past: Essays in the History of New Zealand Education (Wellington: New Zealand Council for Educational Research), p.75-81; Roth, George Hogben, A Biography, p.110-4.

${ }^{203}$ AJHR 1902, E-1, p.xvi.
} 
attempts were largely thwarted. ${ }^{204}$ Somewhat more successful were his attempts to force the Maori colleges to provide more vocational training.

The Native Schools Act 1858 had encouraged rather than imposed schooling in Maori communities: village schools were set up only in response to requests from the community, who were required to feel a degree of ownership over their schools. They were placed under the Education Department in 1880 but remained a separate system, and while the curriculum had initially omitted history and advanced science and grammar - focussing on teaching English above all else - it had become essentially the same as that of the standard state schools by 1914, when Native School teachers were finally accepted as members of the Educational Institute. While accepting that primary schooling for Maori should essentially parallel that provided for Pakeha, administrators did not encourage this policy at a secondary level. ${ }^{205}$

In 1906, Hogben described his success in removing Latin from the curriculum of Hukarere Maori College for Girls, and launched a Royal Commission to advocate similar radical change at Te Aute College: woodwork and farming, not Latin and university preparation. ${ }^{206}$ Former Te Aute students and current MPs Apirana Ngata and Peter Buck advocated retaining the academic education which had allowed them to move on to University education and aided them as leaders. ${ }^{207}$ Maui Pomare, as a Public Health official, had advocated the "hygiene of the home, personal dress, the science of cookery, the nursery of the sick" and "the upbringing of babies" as the core curriculum subjects for Maori girls' schools; he criticised the boys' schools for educating Maori up to the matriculation standard, so that they could say "Et tu Brute... and other pet Latin phrases" but could not stand lowly paid clerk's positions, so drifted back to their people, among whom their skills were of no use. Thus, in spite of reaping the same rewards from Te Aute's classical training as Ngata and Buck, Pomare advocated a syllabus based primarily around practical learning: "Some say that the Maori cannot farm his own land. This may be so, and, if so, whose fault is it? You have taught us how to read and write; you have taught us Greek and Latin; you have taught our

\footnotetext{
${ }^{204}$ G.D. Lee, "From Rhetoric to Reality: A History of the Development of the Common Core Curriculum in New Zealand Post-Primary Schools," (PhD Thesis: University of Otago, 1991).

${ }^{205}$ J.M. Barrington and T.H. Beaglehole, Maori Schools in a Changing Society (Wellington: New Zealand Council for Educational Research, 1974), p.99, 126, 159, 168-73; Simon and Tuhiwai Smith, p.245.

${ }^{206}$ AJHR 1906, G-5, p.82

207 Openshaw, Lee and Lee, p.54.
} 
girls how to couch endearing terms to their lovers: teach us also how to cultivate our lands, in order that we may stand side by side with the pakeha, for work is our only means of salvation." 208 Although Te Aute College did introduce agricultural courses, they proved markedly unpopular with parents: by 1922, the University-oriented Matriculation course had almost three times as many pupils as the agricultural course. ${ }^{209}$

Attempts to ensure that education was differentiated on the basis of gender were more successful: Inspectors examining pupils sitting the proficiency exam were expected to judge girls" work "10 per cent more leniently than that done by boys." ${ }^{210}$ The 1904 syllabus made military drill compulsory for boys over 12 years of age (in schools with twenty or more such pupils), and in 1917 Home Science became compulsory for girls. ${ }^{211}$ Hogben and others promoted having some compulsorily different subjects for boys and girls, but ultimately based upon the same core academic curriculum - an approach universally applauded by those questioned by the Cohen Commission. ${ }^{212}$ Hanan argued not only that "the great majority" of women in paid employment would soon give up this work to "become wives and mothers", but that this was necessary if "our nation" was to "stand in its present high position": the crisis of war meant that the "need of the State to secure the health and physical efficiency of our girls" via gender-specific education policies "was never greater, more imperative, or more urgent". 213

Labour leaders, however, questioned the need for gender differentiation, both in the payment of teachers and instruction of pupils. During debates over the 1914 Act, Payne argued that in attempts to create "a great race the education of women is of more importance, in my judgement, than that of men", since women then became mothers responsible for the education of infants; Webb argued that there should be no differentiation in the treatment of male and female teachers, in spite of Allen defending

\footnotetext{
${ }^{208}$ AJHR 1904, H-31, p.58-9.

${ }^{209}$ Openshaw, Lee and Lee, p.55.

${ }^{210}$ Dorothy Page, Howard Lee and Tom Brooking, "Schooling for a Gendered Future: Gender, Education and Opportunity," in Barbara Brookes, Annabel Cooper and Robin Law ed., Sites of Gender: Women, Men and Modernity in Southern Dunedin, 1890-1939 (Auckland: Auckland University Press, 2003), p.97.

211 Page, Lee and Brooking, p.110.

212 AJHR 1912, E-12 p.713; Openshaw, Lee and Lee, p.112, 132.

${ }^{213}$ AJHR 1916, E-1A, p.8.
} 
higher wages for male breadwinners. ${ }^{214}$ Three years later, when Home Science became compulsory, McCombs criticised the "parliament of men" for their "cool assumption" that "the primary function of women was to learn to cook", when in fact many women did not cook, and "a still larger number, after the war, would have to find other vocations to follow." 215

Parental opposition to vocational training ensured that educational differentiation would have to be enforced by an increase in the power of the central Department of Education over district Boards and local school committees. While the Public School Teachers' Salaries Act 1901 received near-universal support as a measure to raise the meagre salaries of teachers, MP Alexander Hogg, a member of the Wellington Board of Education, criticised it as an attempt by Hogben to take over the control and management "of the whole of the schools of New Zealand". ${ }^{216}$ In 1914, when Allen's Education Act intended to dissolve some of the smaller Boards, members representing those regions spoke out vehemently against the centralisation. Reform member David Guthrie described as "deplorable" the fact that the "Education boards are to be practically wiped out", as he believed that then "the great factor in keeping up local enthusiasm and interest in the local administration will be gone", and he lamented that "what is clearly the aim of the Bill, is eventually to centralize the whole system". ${ }^{217}$ James Craigie, the Liberal member for Timaru (whose Education Board, of which Hogben had once been an employee, was now to be eliminated), went furthest, quoting an Otago Daily Times article to the effect that all forms of political centralisation were inherently "undemocratic" as well as "degenerating": "People maintain their virility only when they shoulder their responsibility themselves [...] Centralization possesses essentially the spirit of autocracy." 218 Certainly, centralising the Inspectors meant that, as employees of the Department, they were now less able to honestly critique educational

\footnotetext{
${ }^{214}$ NZPD 1914, vol.171 p.70, 76. The imposition of a Dominion-wide salary scale at the beginning of the century had gone some distance towards removing discrimination against female teachers, although they were not considered appropriate to be head teachers at the largest schools: Rollo Arnold, "Women in the New Zealand Teaching Profession," in Openshaw and McKenzie, p.49; The Education Act 1914 recognised equal pay for the lower grades of teachers, Roth, George Hogben, A Biography, p.144.

215 NZPD 1917, vol.180 p.521, 525-6.

216 NZPD 1900, vol.115, p.339.

${ }^{217}$ NZPD 1914, vol.171, p.44.

${ }^{218}$ NZPD 1914, vol.171, p.64.
} 
policy, and after 1914 their annual reports become decidedly less interesting to read. ${ }^{219}$ Richard McCallum, Liberal Member from Wairau (whose Malborough Education Board also looked set for extinction) acknowledged he was being parochial in appealing for his district, but added that "we have now gone in for centralization - and centralization to a degree never anticipated when the provinces were abolished [...] The Government seems determined to violate the principle of self-government so far as the smaller education districts are concerned." 220 While such sentiments were clearly inspired by very specific events, they demonstrate the opposition Hogben faced in moving for greater central control.

On the other hand, Josiah Hanan criticised the 1914 Act for not moving far enough in the direction of abolishing the Boards and reducing local control - in particular, Hanan asked that secondary schools be placed under the authority of the Boards to reduce their independence, while the number of the Boards would be gradually reduced until their functions were taken over by the Department. ${ }^{221}$ Like Hogben, Hanan favoured centralisation as a means to ensure greater differentiation of courses "fitted" to the needs of each pupil: "the people would be up in arms in some districts if you were to make it compulsory for youths and girls after leaving the primary schools to attend technical schools or continuation schools. Public opinion needs to be educated on this subject." 222 Two years later, as Minister of Education, Hanan stated that "that the education and training of the present and immediately following generations constitute the greatest reconstructive agencies at our disposal for the repair and reorganisation of national life after the present destructive upheaval" but that such a rejuvenation was being hampered by the "abstractions, formalisms and pedantic studies" of the academic secondary school curriculum. ${ }^{223}$ Although he acknowledged that it was "disastrous" to force children into differentiated courses during the primary years, he argued that "only the really capable pupils should be allowed" to take university-preparation courses at a secondary level. ${ }^{224}$ Compulsory domestic training for female secondary students and compulsory agricultural

\footnotetext{
${ }^{219}$ NZPD 1914, vol.171, p.66; lan Cumming and Alan Cumming, History of State Education in New Zealand 1840 - 1975 (Wellington: Pitman, 1978), p.194;

${ }^{220}$ NZPD 1914, vol.171 p.47-8.

${ }^{221}$ NZPD 1914, vol.171, p.60-1.

${ }^{222}$ NZPD 1914, vol.171, p.62.

${ }^{223}$ AJHR 1916, E-1A, p.1-2.

${ }^{224}$ AJHR 1916, E-1A, p.4-5.
} 
training for pupils at district high schools, introduced in 1917, were Hanan's attempts to enforce more practical training; he had at one point described his ideal of a more vocationally differentiated secondary education system as involving "drafting boys and girls into the technical or high schools according to their capabilities and natural bent." 225

The enforced differentiation of secondary schooling according to future vocation has been the most historiographically contentious aspect of Hogben's educational policy. Roger Openshaw, Greg Lee and Howard Lee contrasted the "liberal curriculum assumptions underpinning the Hogben syllabus", which opposed rote-learning in favour of progressive educational methods, with his desire for "social efficiency" as expressed by the desire for vocationally-differentiated courses. They describe the "doctrine" that education was only "efficient" if it "could sort pupils into discrete categories" based on their abilities and intended careers, as inherently "conservative". ${ }^{226}$ This argument is based on the fact that such differentiation reduced the opportunities for pupils to make their own destiny, regardless of background, and to the extent to which this is true, the argument is valid. Yet it can and has been pushed too far: while efficiency could mean limiting opportunity, it could also mean allowing each pupil to engage in learning which was flexible to their needs, rather than forcing every pupil to learn the same subjects via the same methods, in spite of the different ways in which different children learn. The state's assertion of control over secondary schools is described as liberal, given that it forced these schools to accept nonpaying pupils from working-class backgrounds. On the other hand, the state's assertion of control over the curriculum of both primary and secondary schools is described as conservative when it sought to restrict the future of pupils by requiring greater differentiation of courses based on the backgrounds as well as abilities of pupils.

Too often, the equation that educational differentiation equals conservative social control is simply asserted. This has something to do with non-historical factors: the move to a more critical education history from the 1970s ran into attempts by governments from the 1980s to privatise education; as New Zealand's educational historians have, like the teachers themselves, largely opposed such attempts (as demonstrated clearly by the overwhelming opposition to bulk funding), they have perhaps tempered their historical analysis with a

\footnotetext{
225 NZPD 1910, vol.150 p.884-5.

${ }^{226}$ Openshaw, Lee and Lee, p.100, 104.
} 
desire not to provide ammunition for those who would seek to use revisionist histories to remove rather than reform central administration.

\section{Promoting Imperial Citizenship}

That educational administration became increasingly centralised before and during the First World War is beyond doubt. At times, central policy gave teachers greater freedom - by removing the requirement that pupils below Standard VI be externally examined, Hogben devolved some power from Boards to teachers - but this was aimed at reducing the power of local Boards and parents, not of the central authority. After a number of speakers on the 1914 Act criticised the dissolution of the smaller Boards as an attack on and reduction of local spirit and enthusiasm, others were able to respond that local inspiration was totally irrelevant to the demands of children's education: educators who knew what was best were right to impose correct educational methods, regardless of the wishes of parents. ${ }^{227}$

Given the centralising tendency of educational policy in this period, it is tempting to view the correlating growth of patriotic features within education as a result of this centralisation - as imposed from above - especially given the hypothesis of my thesis. I am arguing that the growth of the Dominion state and the growth of imperial loyalty during this period fed back into one-another. Certainly there is a correlation between the growth of state control over education and the increase in patriotic displays and lessons, and indeed patriotism was both promoted and enforced form the centre.

The Alien Enemy Teachers Act 1915 prohibited any school - whether primary, secondary, tertiary or Native - from employing an "enemy alien" in any teaching capacity, on penalty of losing public funds. ${ }^{228}$ This Act was specifically targeted at teachers because the government already possessed the power to prohibit such people from holding positions in the public service, whereas, although teachers' salaries were paid out of government revenues, their appointment was in the hands of Education Boards or College Councils. ${ }^{229}$ While Massey said that the Act was "general in its application" and not targeted at any individual, speaker

\footnotetext{
227 NZPD 1914, vol.171 p.74, 62.

${ }^{228}$ Alien Enemy Teachers Act 1915, s3, p.361.

${ }^{229}$ NZPD 1915, vol.174, p.707.
} 
after speaker in the debate made it clear that this Act was a direct response to the Victoria College Council's refusal to accept the resignation of Professor George von Zedlitz, a partGerman who had not taken British naturalization even though his German citizenship had lapsed. ${ }^{230}$ Although not "ashamed" of his birth country, von Zedlitz had "rejoiced" at being considered an "Englishman" upon arrival in New Zealand. ${ }^{231}$ Yet after war broke out between Germany and Russia, he had offered his services - in a non-combatant role - to the German consul. His offer was rejected, and after Britain and New Zealand joined the conflict, he offered to resign his position, though this too was rejected. ${ }^{232}$ Mounting antiGerman sentiment grew over the next year, leading members of the public and some MPs to call for him to be removed. While the Attorney General (a member of the College Council) had initially accepted that von Zedlitz was not a threat and should retain his position, the discovery of his offer to the German consul - which became twisted in the public consciousness into an offer to fight against the British Empire - forced the Government's hand. ${ }^{233}$ Unfortunately for von Zedlitz, the Government had already moved to prohibit enemy aliens from naturalizing after the beginning of war, and Massey and Herdman found themselves sandwiched between MPs calling for the internment of all enemy aliens, even those who had naturalized prior to the war, and others asking for those who wanted to naturalize to be allowed to do so - just as they were allowed to do in Britain. ${ }^{234}$ Webb went so far as to describe von Zedlitz' persecution as neither "fair nor British." 235

During the agitation against him, von Zedlitz wrote to a friend that the Government had "done their best to protect me" but that "members of Parliament wanting to pose before their constituents as democrats and patriots" had led the Government to threaten a "big

\footnotetext{
${ }^{230}$ Educated at Oxford University, von Zedlitz had neglected to return to Germany to fulfill his military service.: D.O.W. Hall, "Introduction" in George von Zedlitz, The Search for a Country: The Autobiography of G.W. von Zedlitz (Plymouth: Paul's Book Arcade, 1963), p.8; Andrew Francis, 'To Be Truly British We Must Be AntiGerman': New Zealand, Enemy Aliens and the Great War Experience, 1914-1919 (Bern: Peter Lang, 2012), p.155.

${ }^{231}$ Von Zedlitz, p.84;Michael Childs, Educator, Exile, Enlightener: Professor G.W. von Zedlitz, (Wellington: Jubilee Publications, 1990), p.15-6.

${ }^{232}$ Francis, p.157-8; NZPD 1915, vol.174, p.714-5.Tim Beaglehole, "Zedlitz, George William Edward Ernest von," in Dictionary of New Zealand Biography, updated 30 October 2012, URL:

http://www.TeAra.govt.nz/en/biographies/3z1/zedlitz-george-william-edward-ernest-von 233 NZPD 1915, vol.174, p.708.

${ }^{234}$ NZPD 1915, vol.174, p.710, 712; NZPD 1914, vol.169, p.502, 527; vol.171, p.139-41; Francis, p.74-5.

235 NZPD 1915, vol.174, p.710, 712-3
} 
inroad upon liberty and constitutional rights" by legislating to remove him. Out of a desire to avoid such legislation, he again asked to resign, and even attempted to enlist in the Royal Army Medical Corps; these attempts came to nothing, the legislation was passed, and when, in 1919 , the College had the opportunity to reappoint him, they declined to do so. ${ }^{236}$ The Alien Enemy Teachers Act ended von Zedlitz' professorial career, and represented the first stage of the state's wartime expansion of control over education in the direction of enforcing loyalty to Britain. It was a response to the fact that, although schools and colleges were funded by the central government, they retained a great deal of independence from government interference: wrapping up debate over the Act, Massey concluded that when a "State institution" failed to "do its duty", the only option was for "the Parliament of this country" to "interfere, to put the matter right." The Government had, Massey argued, been "compelled to step in". 237

In 1917, the National Efficiency Board recommended schools conduct weekly flag-saluting ceremonies, to encourage loyalty to the Union Jack and hence the empire at war. ${ }^{238}$ Four years later, in spite of the war having come to a close, the Reform Government made saluting either the New Zealand Ensign or Union Jack compulsory, both once a week as well as on Anzac and Empire Days, to be accompanied by the National Anthem. ${ }^{239}$ The same year, and Education Amendment Act required every teacher to swear an oath of allegiance to the Crown, and refrain from any words or acts "disloyal to His Majesty." 240 These moves to promote or enforce displays of loyalty were accompanied by an imperialist emphasis in the teaching of history: the 1921 flag-saluting regulations were part of a requirement that "History and Civics" lessons "shall aim at instilling in boys and girls love for their country and pride in the achievements of the race throughout the Empire" - no mention was made of the fact that not all New Zealanders were of the same race. "Loyalty" was to be "the dominant note" of these lessons: "The inculcation of patriotism or loyalty to King and country and to lofty ideals readily finds a basis in British History. In this connection lessons of a celebrational character are of the

\footnotetext{
236 Hall, p.17-8.

${ }^{237}$ NZPD 1915, vol.174, p.717.

238 Openshaw, Lee and Lee, p.121.

239 New Zealand Gazette, 1921, vol. ii, p.1582-3.

${ }^{240}$ Education Amendment Act 1921, s11, p.263-4.
} 
utmost importance, and anniversaries such as Anzac Day and Empire Day should be devoted to special lessons appropriate to the theme." 241

Josiah Hanan believed that "history and civics of a character calculated to give a sound basis for patriotism and desire to serve one's country" should be one of the general subjects taught at all secondary schools, whether technical and academic, and that such teaching was part of the State's "policy of self-defence." 242 Though a supporter of more specialised and vocational secondary schooling, Hanan ultimately sought to create "not merely the technically competent workman, but the citizen of the State" who placed the good of the wider community above his own welfare. ${ }^{243}$ Massey wanted the teaching of history to focus upon "the great men of the past", from Queen Boadicea and King Alfred through to Kitchener and Haig, in order to instil "pride of race - it does not matter what race they belong to in the British Empire - pride of Empire, and love of country" in the hearts and minds of the "rising generation". 244

Beyond asking that teachers adhere to the promotion of patriotism via history lessons, administrators tried to ensure that this was implemented by publishing history textbooks which stressed the reader's duty to King and country. Whitcombe and Tombs had produced textbooks for New Zealand schools from the 1880s, after some Catholics complained about the sectarian material contained in many British "readers". ${ }^{245}$ The Imperial Readers they produced from 1897, and the Pacific Readers that replaced them in 1911, were the standard texts for the various subjects covered, including history. ${ }^{246} 1878$ regulations stipulating that children were to use only one reading book for each standard ensured some uniformity across the schools of the country, and mean that we can draw inferences about the content of actual lessons from the Whitcombe and Tombs texts. ${ }^{247}$ However, we do not know to what extent teachers adhered to the messages these books asked them to impart. ${ }^{248}$ We do

\footnotetext{
241 New Zealand Gazette, 1921, vol. ii, p.1583.

242 AJHR 1916, E-1A, p.4-5.

243 AJHR 1916, E-1A, p.6.

244 NZPD 1918, vol.183, p.186-7.

245 Colin McGeorge, "'New Zealand' in New Zealand School Books Before 1930," History Now 10, 2 (Spring 2005), p.4-5.

${ }^{246}$ Hugh Price, "Reading Books and Reading in New Zealand Schools, 1877-1900," in Openshaw and McKenzie, p.184.

247 Price, p.185.

248 Rachel Patrick, "'An Antidote to Bookishness': Local History, Educational Practices and Colonialism in New Zealand Primary Schools, 1900-1940," New Zealand Journal of History 45, 2 (2011), p.193.
} 
not know that the history as laid out in these texts was exactly the history taught in classrooms across the country, but we do know that it was the history teachers were expected to teach.

The history narrated in these texts was a British nation-based history, following the rise of Britain from the beginning of the English monarchy through to imperial expansion and the colonisation of New Zealand: "Let us note how the power of this little country" - medieval England - "grew until it spread itself over the earth." 249 It is an absolutely perfect example of "Whig history", a story of almost uninterrupted progress, from the darkness and ignorance of the middle ages to the enlightened liberal democracy of Victoria: "New Zealand is ruled by the people for the people, and is one of the best-ruled countries in the world"; its history "has been a change for good, a growth, not a decay." 250 The Southern Cross textbooks produced in the 1880s, which became the target of a boycott after Whitcombe and Tombs was criticised by the Sweating Commission, even claimed that "In New Zealand when the people, no matter how poor they may be, sit down to their breakfast, there is always a nice loaf of wheaten bread on the table, or scones made of wheaten flour. Boys and girls in this country, by asking their mothers, can get a piece of bread and butter whenever they feel hungry." 251

In this triumphalist narrative, the Anglo-Boer War was primarily seen as a victory for the health of the empire: "Fighting thus side by side and shedding their blood in the cause of their Empire, men from all parts of the British dominions learnt to know one another better, and made firmer resolves than ever to keep the Empire united." 252 Children were encouraged to put the needs of their people before themselves: "The selfish man or the selfish nation is doomed." 253 The Empire "should not be allowed to drift asunder" because Britain was "the most progressive and most just of modern nations." It was therefore right "that she should guide and control the destiny of new and infant countries; to her and no

\footnotetext{
${ }^{249}$ James Hight, Historical Reader for Standard III: Outline History of the British Empire (Christchurch: Whitcombe and Tombs, 1909), p.7-8, 191.

${ }^{250}$ Hight, Historical Reader for Standard III: Outline History of the British Empire, p.9, 191.

${ }^{251}$ Southern Cross History No.3 (Christchurch: Whitcombe and Tombs, 1903), p.149; see also William Gillies, Historical Reader for Standard V: The Story of the British Empire from the Beginning of the Stuart Period to the Reign of Queen Victoria (Christchurch: Whitcombe and Tombs, 1909), p.257-8.

252 Hight, Historical Reader for Standard III: Outline History of the British Empire, p.162.

253 Gillies, p.314.
} 
others should be committed the fate of the lower races of mankind". ${ }^{254}$ The Sixth Standard historical reader concluded with a section on Imperial Federation, arguing that the lessons of history teach "the paramount duty of fostering, instead of arresting, this growth of a Greater Britain, especially as all present signs seem to point to a great State as the common type of political organisation in the future. If England wishes to maintain her place of honour among these states, she, too, must expand; and her only channels for natural and healthy expansion are her colonies." 255

These lessons were reiterated in the School Journal. Hogben created this free monthly journal in 1907 in response to complaints about a lack of uniformity in the textbooks used throughout the country, in spite of Whitcombe and Tombs dominance of the market. ${ }^{256}$ Its use was made compulsory in 1914, and a 1939 study estimated that most classes spent at least half an hour every day studying the Journal, so it is reasonable to presume that its messages reached most of the country's school-children. ${ }^{257}$ The same study calculated that in 1916 more than seventy per cent of the Journal's pages had been devoted to war, the empire and the monarchy, though this percentage declined slowly from this point. ${ }^{258}$ Cabinet Ministers themselves took to penning Journal articles promoting the virtues of empire. ${ }^{259}$

The most outstanding example of imperialist propaganda in the pages of the School Journal is probably the Earl of Meath's Empire Day address from 1914, which has been quoted by several historians of the journal in this era. ${ }^{260}$ Meath stressed that the British Empire was "a majestic community of free nations freely governing themselves, owing its being to vast sacrifice" and "bound together by one King, one Flag, and one Navy". ${ }^{261}$ In contradiction to this promotion of the loyalty to the naval forces and Union Jack, Meath also stated that the "Empire movement" was neither "aggressive" nor "flag-wagging". For Meath, the Empire

\footnotetext{
254 James Hight, Historical Reader for Standard VI: History of the British Colonial Empire (Christchurch: Whitcombe and Tombs, 1911), p.11.

${ }^{255}$ Hight, Historical Reader for Standard VI: History of the British Colonial Empire, p.281.

${ }^{256}$ E.P. Malone, "The New Zealand School Journal and the Imperial Ideology," New Zealand Journal of History 17,1 (1973), p.12-3.

${ }^{257}$ AJHR 1914, E-2, p.10; D.R. Jenkins, Social Attitudes in the New Zealand School Journal, (Wellington: New Zealand Council for Educational Research, 1939), p.3.

258 Jenkins, p.4.

259 Openshaw, Lee and Lee, p.122

260 Openshaw, Lee and Lee, p.8-9; Malone, p.15-7

${ }^{261}$ School Journal Part II, VIII, 5, (June 1914), p.132.
} 
was defined by "responsibility, duty, sympathy, self-sacrifice." Duty could not be stressed enough: "Too many are thinking of their rights and privileges. We are trying to teach the rising generation to look to its duties." 262 While a citizen's duty was to the Empire at the centre, this duty required the strong and successful to "consider the poor and suffering", just as the British race had to take responsibility for the "lesser" races within the Empire. ${ }^{263}$ This conception of imperialism as a duty of the strong to guide the weak encapsulated the "liberal imperialist" view of Hogben of the Empire as a "civilising force": while Journal articles held Germany responsible for the war, they did not dehumanise the enemy as a marauding horde. ${ }^{264}$ Children were taught to love their Empire and serve it as a force for good.

In the decade after the end of the war, textbooks including the Journal celebrated the heroism of British and colonial troops. The 1928 history textbook Our Nation's Story took this celebration to such an absurd extreme that it could claim that, although Britain was defeated at Gallipoli, nevertheless "the story of Anzac is as splendid as any tale of victory, for it is the story of the greatest deed ever done by men. You may search our history in vain to find its equal." 265

Imperial military rhetoric did not decline with the end of war, and neither did the state's attempts to impose patriotism in the classroom: three years after the armistice, the Government made flag-saluting ceremonies compulsory, and demanded an oath of loyalty from all teachers. ${ }^{266}$ These measures were the product of new Education Minister, C.J. Parr, a former head of the Auckland Education Board and, more pertinently, fervent antiSocialist. ${ }^{267}$ Parr furthered Hanan's dental service and the nation-wide grading and appointment of teachers, but it was his move to suppress disloyalty among the teaching profession that most defines his term as Minister. Parr justified compulsory flag-saluting as a response to the "threat" of Socialist Sunday Schools: these "disruptive influences [...] treated with contempt national feeling and tended strongly to revolutionary socialism, and

\footnotetext{
262 School Journal Part II, VIII, 5, (June 1914), p.133.

263 School Journal Part II, VIII, 5, (June 1914), p.134.

264 Malone, p.18.

265 Our Nation's Story: Standard III (New Zealand: Whitcombe and Tombs, 1928), p.182.

${ }^{266}$ New Zealand Gazette, 1921, vol. ii, p.1582-3; Education Amendment Act 1921, s11, p.263-4.

267 Graham W. A. Bush, "Parr, Christopher James," - Parr, Christopher James', in Dictionary of New Zealand Biography, updated 30 October 2012, URL: http://www.TeAra.govt.nz/en/biographies/3p10/parr-christopherjames
} 
also class warfare". ${ }^{268}$ He believed that "a very strong public opinion" supported his view "that it is the business of the Department to see that our teachers are loyal to King and country", for "if you are going to have disloyal teachers, you are going to have disloyal children." 269

In the same month that the flag-saluting regulations were gazetted, police arrested a student at Wellington Teachers College for distributing "literature encouraging violence and lawlessness", under a law passed the previous year. The student, Hedwig Weitzel, was promptly convicted, but after fellow students helped pay her $f 10$ fine Parr demanded an Education Board inquiry into subversive politics at the College. ${ }^{270} \mathrm{He}$ was assisted in this aim by the fear of her German-sounding name: and she was promptly expelled, but the support the College gave her during the trial provided Parr with the justification for legislating to demand all teachers swear an oath of loyalty later that year. ${ }^{271}$

As well as suppressing dissent, Parr also promoted loyalty by encouraging schools to hold visits from the Navy League. In October 1921, the same month that Parr introduced the oath of loyalty requirement, the Auckland City Schools Committee refused to allow the Navy League access to three schools on Nelson Day, opposing "the fostering of any 'military' spirit" in education. ${ }^{272}$ The New Zealand Herald criticised the Committee's actions "particularly at a time when a political party definitely opposed to the principles of the British Constitution is organising and planning to carry out its insidious propaganda designed to appeal to the ignorant and unthinking." 273 Following criticism from the Education Board and the Prime Minister, the Schools Committee agreed to give the Navy League access, and Nelson Day was celebrated by the Herald with no mention of the controversy. ${ }^{274}$

Although Parr pushed the inculcation of loyalty via education policy even further in the postwar period, there were some counter-currents to this trend. Analysing the amount of space given to the various subjects within the Journal, D.R. Jenkins concluded that war- and empire-themed material was steadily increasing by the outbreak of war, but had started to

\footnotetext{
268 New Zealand Herald, 27 May 1921, p.4.

269 NZPD 1921, vol.191, p.933-4.

270 J.C. Beaglehole, Victoria University College (Wellington: New Zealand University Press, 1949), p.191-2.

${ }^{271}$ New Zealand Herald, 14 October 1921, p.6; Openshaw, Lee and Lee, p.123-4.

272 New Zealand Herald, 11 October 1921, p.6.

273 New Zealand Herald, 14 October 1921, p.5.

${ }^{274}$ New Zealand Herald, 22 October 1921, p.7; Openshaw, Lee and Lee, p.127.
} 
decline by 1919; as war-fatigue set in, and the public began to observe the horrors of war through casualty lists and returning wounded servicemen, the triumphalist note of earlier School Journal articles was replaced with more sober reflections on duty. ${ }^{275}$

Parr's triumph in the Weitzel case encouraged the Minister in his efforts to root out more subversive teachers, but he overplayed his hand. The following year, Wellington Education Board declined to dismiss a teacher accused of "disloyalty and insubordination". Parr believed the Education Act gave him power to personally dismiss any teacher, but in the Supreme Court, Justice Salmond found that the regulation giving him such power was "utra vires and void." 276 As Solicitor-General during the war, Salmond had been a strong supporter of executive power, so this ruling is particularly striking coming as it does from his hand. Alex Frame has stated that the ruling's significance "lies in its rejection of the argument that an Act which give the Executive power to make regulations 'for any purpose which [it] thinks necessary...' provides the Executive with an uncontrolled power."277

Massey felt compelled to introduce the Alien Enemy Teachers Act 1915 due to a lack of Ministerial control over the employment of state-funded educators, and in 1922 this independence of teachers was reaffirmed by the Supreme Court granting an injunction "restraining the Minister of Education from doing any act whereby he purports to cancel or suspend on the ground of immoral conduct or gross misbehaviour the certificate held" by the teacher in question. ${ }^{278}$ Two years later, in an article titled "An Over-regulated Service", teachers claimed that the Minister's attempts to control every aspect of classroom life were pushing the Department to "the edge of a precipice"; Parr subsequently promised to consult teachers before issuing further regulations. ${ }^{279}$ In spite of such setbacks, the educational trend at the end of the war was predominantly one of tightening control, encouraging patriotism and suppressing dissent. As such, we have clear evidence of the positive impact of war upon the centralisation of teaching.

\footnotetext{
275 Jenkins, p.4, 20-1.

276 Park v Minister of Education, N.Z.L.R., 1922, p.1208, 1212; Alex Frame, Salmond: Southern Jurist

(Wellington: Victoria University Press, 1995), p.224-7.

277 Frame, p.227.

278 Park v Minister of Education, p.1219.

${ }^{279}$ National Education, 1924, p.16; Ewing, p.165-6.
} 
Yet we have also seen how the war meant politically sensitive education policies - such as the further reduction in the number and powers of Education Boards - were abandoned during wartime, due to the need to ensure loyalty and unity across the Dominion; and also how war meant that the rate of growth of the Education Department slowed in comparison to the rate of growth of the state as a whole, even excluding the cost of the war itself. War for empire could in some ways hold back the growth and centralisation of education, so that although central government emerged from the war with qualitatively more power to enforce obedience among teachers, there was no quantitative growth in the Education vote, relative to the overall advance of the state. Wartime imperialism had both positive and negative impacts upon the power of the State over teaching.

In looking at the flipside of this relationship - the impact of centralisation on imperial loyalty - we must be aware that correlation does not necessarily entail a causal link. Furthermore, if we look at the history of the volunteer militia in the decades prior to the outbreak of war, we see how popular imperial loyalty could run into conflict with the state's desire for economy and efficiency: each major external military scare inspired a burst of volunteer soldiering, followed by Government attempts to reduce volunteer numbers into a more militarily-useful force. ${ }^{280}$ This tension between popular military volunteering, and the state's need for efficiency, impacted education policy by way of the cadet movement.

The cadet movement grew in popularity with volunteering, until in 1902 the Education Department agreed to take some responsibility for overseeing school cadet forces. In 1909, when compulsory military training for adults was introduced, so too was compulsory cadet training for boys aged 12 to 14 (as junior cadets, under the eye of the Education Department) and 14 to 17 (as senior cadets under the Defence Department). Yet Lord Kitchener's report soon criticised the idea of twelve year olds undertaking military drill and training, and in 1912 the new Reform government abolished the junior cadet corps. ${ }^{281}$ Efficiency could be the catch-cry behind greater centralisation in education, against the wishes of some parents, but it was also the reason given by the government for not bowing to popular patriotism in some aspects of military and educational administration.

\footnotetext{
${ }^{280}$ Tristan Egarr, "Discipline and Defence: The Military Influence on Policing and Imprisonment, c.1870-1913" (MA Thesis, Victoria University of Wellington, 2010), p.65.

${ }^{281}$ Roger Openshaw, "The Patriot Band - The School Cadets From Their Evolution to the Great War," (MA Thesis: Massey University, 1973), p.54.
} 
Finally, having detailed the various means by which the State sought to insure patriotism and loyalty to the war effort in education, I must conclude by noting that the bulk of warrelated activities in schools were both voluntary and popular with pupils. School children held fundraising concerts for Belgian refugees, farewelled departing troop contingents, knitted clothing to send to the front. ${ }^{282}$ As such, centrally-imposed regulations ensuring loyalty must be seen as a response to the fear of a disloyal minority, and not as an unpopular means to control the majority.

282 Jeanine Graham, "Young New Zealanders and the Great War: exploring the impact and legacy of the First World War, 1914-2014," Paedegogica Historica 44, 4, (2008), p.431-3, 435-6. 


\section{Government Intervention in the Dominion Economy}

The First World War injected a massive stimulus into the New Zealand economy - from 1914 to 1919 , the country's total trade grew by seventy-five per cent, driven by the British Government's commandeer of meat, wool and dairy exports; Keith Rankin's estimates of Gross National Product during the same period show growth of just over fifty per cent. ${ }^{283}$ Meanwhile, the State's role in the economy grew at an even greater rate than the economy itself: crown revenue almost doubled, as did non-military expenditure. ${ }^{284}$ As the cost of the war, more than eighty million pounds, was funded out of loans, the public debt also doubled between 1914 and $1920 .{ }^{285}$

That such a substantial military effort involved both great expense and an expansion in the tax base is unsurprising, as is the increase in pastoral exports to feed the combined military of the British Empire. But that non-military government expenditure doubled and that imports increased by almost fifty per cent is surprising, given contemporary discourse in favour of war-time austerity. The First World War provided an impetus to both general economic growth and state involvement above and beyond that required by the demands of the military effort. This growth was tied to the demands of the British Empire at war: New Zealand's economy became more firmly centred around pastoral exports and trade with the Mother Country, a move facilitated by Government regulation.

\section{Historiography}

"If there is any prevalent theory as to the scope of governmental activity" in New Zealand, wrote the young Reform Party politician W.D. Stewart in 1910, "it is a form of paternalism,

\footnotetext{
283 NZOYB, 1920, p.123; Keith Rankin, Gross National Product Estimates for New Zealand 1859 - 1939, Working paper series 1/91 (Wellington: Graduate School of Business and Government Management, Victoria University of Wellington, 1991), p.14. Rankin puts real GNP growth at six per cent; attempts to calculate GDP rather than GNP do not go back to 1914: Phil Briggs, Looking at the Numbers: A View of New Zealand's Economic History (Wellington: New Zealand Institute of Economic Research, 2003/2007), p.35-9.

284 NZOYB, 1920, p.328.

285 NZOYB, 1920. P.344; James Allen, “New Zealand in the World War," in J.H. Rose, A.P. Newton, E.A. Benians, and J. Hight eds., The Cambridge History of the British Empire, Volume 7: New Zealand (Cambridge: Cambridge University Press, 1933), p.235.
} 
which regards the State as the parent or guardian of the people". ${ }^{286}$ Looking back on the price fixing schemes of the First World War and its aftermath, Labour-aligned civil servant W.B. Sutch stated that "John Stuart Mill would have few followers in New Zealand judging by their policy of protecting producers at the expense of consumers"; Keith Sinclair claimed that even in the 1880s "only a few extreme Conservatives still followed" laissez-faire policy ideals. ${ }^{287}$ Michael Bassett contrasted the pro-intervention New Zealand state of that era with the less-statist Mother Country. ${ }^{288}$ While outsiders described the Liberal reforms of the 1890 s as state socialism, albeit without much adherence to doctrines, domestic observers following Stewart have been less likely to link willingness to intervene with the ideal of socialism, seeing it more as a pragmatic response to the needs of a new and isolated developing colony - opportunistic statism rather than ideological socialism. ${ }^{289}$ "Nevertheless", Gary Hawke argued, the state's economic intervention "went beyond what was needed to exploit its advantages." 290

In contrast, other historians have described the New Zealand economy of 1914 as distinctly non-interventionist. A.J. Everton claimed that "The First World War was not a period when the Government intervened in the economy to a great extent" and that Massey's government held to "a belief in the efficacy of the free market." 291 Tom Brooking similarly wrote that "the state [...] made little attempt to regulate commercial activity until 1930." 292 Justin Strang's thesis on welfare policy under Reform concludes that fiscal policy under this government reflected "a desire to minimise the burden of government", and that this desire was shared with the previous Liberal administration. ${ }^{293}$ The divergence in these two groups of statements regarding the New Zealand State around 1914 - as alternately interventionist

\footnotetext{
${ }^{286}$ J.E. Le Rossignol and W.D Stewart, State Socialism in New Zealand (London: George G. Harrap, 1910), p.18.

${ }^{287}$ W.B. Sutch, Price Fixing in New Zealand $2^{\text {nd }}$ edn. (New York: AMS Press, 1968), p.119; Keith Sinclair, $A$ History of New Zealand, $2^{\text {nd }}$ edn. (Harmondsworth: Penguin, 1969), p.172.

288 Michael Bassett, The State in New Zealand 1840-1984: Socialism Without Doctrines? (Auckland: Auckland University Press, 1998), p.123.

289 J.B. Condliffe, New Zealand in the Making $2^{\text {nd }}$ edn. (London: Allen and Unwin, 1959), p.183, 185; G.R. Hawke, The Making of New Zealand: Economic History (Cambridge: Cambridge University Press, 1985), p.105; Sinclair, p.188.

290 Hawke, p.115.

${ }^{291}$ A.J. Everton, "Government Intervention in the New Zealand Economy, 1914-1918 - its aims and effectiveness" (MA thesis, Victoria University of Wellington, 1995), p.3, 30.

292 Tom Brooking, "Economic Transformation," in W.H. Oliver and B.R. Williams eds., The Oxford History of New Zealand (Wellington: Oxford University Press, 1981), p.244.

293 Justin Strang, "Welfare in Transition: Reform's Income Support Policy, 1912-1928," (MA thesis, Victoria University of Wellington, 1992), p.ii, 25.
} 
or non-interventionist - are not due to the personal views of the authors or the era in which they were writing: Bassett, an anti-interventionist writing in the 1990s, draws the opposite picture to Everton, another anti-interventionist writing in the same decade, but the same picture as Sutch, a pro-interventionist writing in the 1930s.

Ultimately, the existence of such contradictory general statements suggests that the New Zealand state was either relatively pro- or anti-intervention, in comparison with other states of the time, depending on what aspect of the state one is most concerned with. Writing on welfare policy in colonial New Zealand, David Thomson noted that New Zealand, "perhaps even more than the other Australian colonies, was marked by a deliberate attempt to keep all formal collective welfare activity to a minimum", but that this contrasted with the "many arenas" in which the same state was "often and unusually highly active" - in "promoting immigration, selling land, developing infrastructure, running railways, reforming working conditions, and regulating economic activity and social life." 294 Similarly, Strang contrasts the lack of government welfare provision with the state's role in providing infrastructure: "Economic development drove state policy up to and beyond 1928." 295 Thomson's contrast between reluctant welfare policy and willingness to regulate "economic activity" still conflicts with the statements made by Everton and Brooking above, but broadly speaking a divide between public and parliamentary enthusiasm for intervention to develop the economy - particularly in providing infrastructure such as railways, which were funded and controlled much more by the central state in New Zealand than in other English-speaking countries - and support for non-intervention in other areas is accurate. ${ }^{296}$

However, while historians' conclusions as to how interventionist was the New Zealand state depend predominantly on the area of the state with which they are concerned, nevertheless a clear historiographic turn away from pro-interventionist attitudes is discernible in some texts following the Rogernomics era of the 1980s. This chapter draws heavily on three such economically right-wing theses from the 1990s: two MA theses from Victoria, A.J. Everton's "Government Intervention in the New Zealand Economy, 1914-1918 - its aims and

\footnotetext{
294 David Thomson, A World Without Welfare: New Zealand's Colonial Experiment (Auckland: Auckland University Press, 1998), p.18.

295 Strang, p.ii.

296 This chapter is concerned with the state's role in the economics of commodity markets (and the related infrastructure), taxation and welfare; industrial disputes are discussed in the chapter on justice policies.
} 
effectiveness" (1995), and Justin Strang's "Welfare in Transition: Reform's Income Support Policy, 1912-1928" (1992); and Ashley Gould's 1992 PhD from Massey, "Proof of Gratitude? Soldier Land Settlement in New Zealand After World War I'.

Although Everton professes an ideologically rigid anti-interventionist perspective, he is careful to qualify his claims, his research is extensively detailed and his conclusions largely hold. While Everton is concerned with criticising Reform and National policy rather than evaluating the policy-makers themselves, Gould and Strang use their theses to defend Massey and the Reform Party. Strang, as I will show in my section on welfare policy, utterly fails in this aim. He largely ignores the fact that Reform were in a coalition with the Liberals for most of the war, and his claim that Reform welfare policy was more or less identical to Liberal policy suffers from this absence.

Gould is much less careful in his use of anti-interventionist rhetoric than Everton: he repeatedly uses the term "paternalism" without much analysis, and claims that ongoing financial support from the Government came "at the price of the soldiers' functional farming independence", that due to "Government intervention [...] the settlers had greater difficulty obtaining seasonal finance from commercial sources", yet provides little to substantiate this supposed negative effect of intervention (the one exception being the problems associated with a ten-year moratorium on resales). ${ }^{297}$ On the other hand, his repeated claims that soldiers suffered from state paternalism are flawed. The problem with this negative depiction of paternalism is that the term paternalism encompasses financial assistance as well as farm supervision, restrictions on the sale of stock, and the ten-year moratorium on reselling soldier farms. While Gould cites a small number of soldiers responding unhappily to the restrictions on stock and farm sales, there are plenty of examples within his thesis of soldier settlers positive responses to supervision (as well as requests for further financial aid). ${ }^{298}$

Ultimately, Gould, like Strang, aims to show that "for ideological and political reasons", previous historians who have studied his topic have "misunderstood and misrepresented"

\footnotetext{
${ }^{297}$ Ashley Gould, "Proof of Gratitude? Soldier Land Settlement in New Zealand After World War I" (PhD Thesis: Massey University, 1992), p.222, 263-4. For uses of paternalism, see p.196-7, 207-8, 221, 255, 257, 272-3.

${ }^{298}$ Gould, “Proof of Gratitude?", p.199-200, 202, 208, 260, 272-3. For negative responses to restrictions: p.212, p.263-4.
} 
aspects of it, being "blinkered to the achievements of the Reform Government". ${ }^{299}$ Gould is more successful than Strang, in that he does show that some of the most extreme claims regarding the failure of the Soldier Settlement Scheme - those of Boyack and Tolerton overstate the extent to which the Government failed soldier farmers in the 1920s and 1930s: he proves that the Government gave ongoing assistance - beyond the ordinary - to soldier farmers throughout this era. ${ }^{300}$ Yet to strengthen his argument, he relies too heavily on the most extreme statements - turning the previous historiography into something of a straw man - and cheap-shots: Sinclair, Boyack and Tolerton are described as "harsh, morally self-satisfied, and accusing", with no explanation of why "morally self-satisfied" is more accurate than "morally outraged". ${ }^{301}$

Furthermore, Gould's emphasis on how the Government's financial support ensured and maintained the long-term "victim status" of soldiers smacks of ideological assumption, and does not ultimately make much sense: surely a refusal to help soldiers would give subsequent historians much greater reason to view the settlers as victim ${ }^{302}$ In spite of these flaws, Gould's thesis remains by far and away the most thorough and rigorous study of the Discharged Soldiers Settlement Scheme, and provides the basis for my section on that subject.

\section{The Development of Economic Regulation to 1914}

John E. Martin has tied the involvement of the colonial state in economic development to the "contract" between settlers and the New Zealand Company: British settlers travelled to the far side of the world in the expectation that they would be provided with the opportunity to develop a new society, but this development was impossible without coordinated effort. ${ }^{303}$ In the 1870 s, as Julius Vogel led the colony in a major infrastructural development using overseas loans to build roads and railways, it became clear that only central government was able to provide the necessary coordination to ensure economic

\footnotetext{
299 Gould, "Proof of Gratitude?", p.II.

300 Gould, "Proof of Gratitude?", p.4, 260-1.

301 Gould, "Proof of Gratitude?", p.6.

302 Gould, "Proof of Gratitude?", p.223, 252.

303 John E. Martin, Honouring the Contract (Wellington: Victoria University Press, 2010), p.11, $19,24$.
} 
progress. Besides the developing transport networks and abolishing the provincial governments, the central state in this period also established a Post Office Savings Bank, Government Life Office and Public Trust Office, and formed a close working relationship with the Bank of New Zealand, which it later rescued and helped manage from 1894 . These economic interventions meant that the State competed against private financial institutions to ensure the cost of such services remained within reach of its citizens, while still allowing private organisations relative freedom of action: state financial interventions were supplementary more than regulatory. ${ }^{304}$ W.J. Gardner wrote that while the private sector was "the intended beneficiary of state action, Vogel introduced New Zealanders to the extended use of state power." In spite of their British sense that private enterprise was "the natural economic order", the colonists "were compelled to look to the state as the only agency with the financial power to lift the colony out of its stagnation", a lift that could only be funded by British investment - thus, Vogel's state-driven internal development projects consolidated ties to Britain: "New Zealand entered into a more truly colonial relationship after $1870^{\prime \prime} .^{305}$ In spite of contemporary laissez-faire ideas, the state's role in driving development was "not seriously disputed" by taxpayers. ${ }^{306}$ Furthermore, voters' acceptance that the private finances of "business politicians", particularly Thomas Russell and his allies in the 1860s, and Joseph Ward in the 1890s, benefitted from the state's relationship with the Bank of New Zealand, suggests a general acceptance that, at least within a small, developing economy, the "line between personal and public affairs was sometimes blurred or even crossed." 307

In spite of the acceptance of state interference in economic matters, New Zealand's tariffs remained lower than those of Australia, and while the imposition of significant manufacturing tariffs in 1888 and their extension in the 1890s was argued for in terms of fostering industrial development, they remained primarily a revenue-collecting exercise. ${ }^{308}$

\footnotetext{
${ }^{304}$ Hawke, p.110-12; Brooking, p.241, 243-4.

305 W.J. Gardner, "A Colonial Colony," in Oliver and Williams, p.70-1, 74.

$306 \mathrm{Jim}$ McAloon, "The New Zealand Economy, 1792-1914," in Giselle Byrnes ed., The New Oxford History of New Zealand (Melbourne: Oxford University Press, 2009), p.209.

307 Gardner, p.72; Hawke, p.116-7.

308 McAloon, p.216; Brooking, p.242, 246; Hawke, p.112-4; Bertram, p.557; Condliffe, p.179, 193; Gardner, p.83.
} 
Indeed, given the light land and income taxes of the pre-war period, customs levies constituted more than half of all tax revenue. ${ }^{309}$

The Liberal Government elected in 1890 expanded upon a state which was already relatively centralised and involved. The Liberals continued to increase state involvement in the direction of railways (placing their administration under direct Ministerial supervision), and supplemented this with the ownership of state coal mines from $1901 .{ }^{310}$ They also reformed the country's tax code, repealing the flat-rate, penny-in-the-pound property tax on all property over $£ 500$, with a more substantial Land and Income Tax Act in 1891 . These taxes remained very low - income tax applied only to those earning over $f 300$ per year, with a top rate of five per cent - and were mutually exclusive. More than three-quarters of Government revenues still came from customs and excise taxes, railway fares and postal and telegraph charges, so the major significance of the new Liberals tax legislation was "the introduction of the progressive principle" instead of flat rates. ${ }^{311}$

The Liberals' most significant advances were in two relatively new directions: in the employment regulations championed by William Pember Reeves, and in assistance to farmers championed by John McKenzie. The centrepiece of Reeves' reforms, the Industrial Conciliation and Arbitration Act 1894, compelled employers and employee unions to accept the ruling of a Court of Arbitration on wage disputes; this innovation was supplemented by a raft of other acts regulating workplace conditions. ${ }^{312}$ McKenzie's Lands For Settlements Act of 1894 (building on a milder Act from 1892) permitted the Government to borrow £250,000 per year to purchase land, and included a compulsory purchase provision allowing the state to force large landholders to sell, while the Advances to Settlers Act 1894 provided cheap credit to small farmers seeking to settle on this land. While McKenzie used compulsory purchase only twice in six years, the measure was significant in that it overrode "the sanctity attached to the private ownership of land by British political theory," and that this shift was supported by the majority of the electorate. ${ }^{313}$ McKenzie also expanded the Agricultural Division of the Department of Lands into a separate Department of Agriculture

\footnotetext{
${ }^{309}$ NZOYB, 1920, p.337.

${ }^{310}$ Brooking, p.239; Condliffe, p.221-2; Hawke, p.112.

${ }^{311}$ Condliffe, p.198-9.

312 Hawke, p.114; Condliffe p.175, 212-4.

313 Hawke, p.105-6; Condliffe, p.208; Geoff Bertram, “The New Zealand Economy, 1900-2000," in Byrnes, p.554.
} 
in 1892, and introduced several Diary Industry Acts to provide farmers with training and require them to meet certain standards which allowed consumers to purchase New Zealand products with some certainty of quality. ${ }^{314}$ McKenzie's legislation achieved his aim of encouraging closer rural settlement, by opening up almost four million acres of land to farmers provided with the financial backing of the state - but the majority of this land was taken from Maori rather than the large estate owners, and Maori were not eligible for state loans to become small farmers. ${ }^{315}$

The success of McKenzie's drive towards small-scale farming hinged upon the introduction of refrigerated shipping in 1882, which made such farms economically viable, as New Zealand's major export staple, wool, was supplemented first by frozen meat and, once the necessary infrastructure was in place, with dairy produce. New Zealand farmers were fortunate that the beginnings of these industries coincided with an upswing in the price of their products on the London market from the mid-1890s. ${ }^{316}$ High prices for pastoral products meant that New Zealand's balance of trade was mostly positive after 1886, with real income per capita maintaining an average yearly growth rate of one per cent until the war, but as high as three per cent in the decade from 1893. ${ }^{317}$ The result of this spectacular prosperity was a highly specialised pastoral economy dominated by a handful of primary products - wool, meat, cheese and butter - and a single market, Britain. ${ }^{318}$ In 1914, pastoral products constituted eighty-five per cent of New Zealand's exports, while Britain received eight-one per cent of all exports and provided more than half of all imports. ${ }^{319}$ J.B. Condliffe observed that New Zealand's economic development may be regarded as "part of the industrialisation of Britain." 320 The New Zealand government's economic intervention were geared towards tightening the relationship between antipodean provider of primary produce and imperial marketplace to such an extent that New Zealand actually deindustrialised at the same time as its wealth increased. ${ }^{321}$

\footnotetext{
${ }^{314}$ Brooking, p.233-4; Gardner, p.82; Hawke, p.92; Condliffe, p.209-10.

315 McAloon, p.214; Brooking, p.238.

${ }^{316}$ Condliffe, p.41-2, 244-7.

${ }^{317}$ Hawke, p.76-9.

318 Bertram, p.544, 553-4.

${ }^{319}$ NZOYB, 1920, p.123, 130, 135, 153.

${ }^{320}$ Condliffe, p.57.

${ }^{321}$ Bertram, p.542.
} 
Another side effect of this economic transition was an increasing cost of living and, more specifically, inflated land values: cheap state credit to farmers seeking land and high prices for their produce combined to drive up land values, lumping farmers with hefty loans which made their prosperity dependent upon ever increasing external prices. ${ }^{322}$ As the influence of the state-supported single-market, single-industry economy became even more extreme under wartime conditions, such inflationary effects created new demands for state intervention. The Discharged Soldiers Settlement Scheme loaned $£ 23.5$ million to 22,792 land-buyers; with prices inflated by the scheme's impact on the market, many of the returned soldiers found themselves farming over-valued land while war-time prices began to subside, adding to other pressures on the Government to extend war-time price controls. 323

\section{The Economy in 1914 and 1919}

When campaigning against the Liberal Government, W.F. Massey's Reform Party promoted the virtues of individual self-reliance as opposed to the "state socialism" of the Liberals. Yet once they attained office in 1912, Reform's only reductions in central state control were offering freehold tenure to farmers occupying leasehold land owned by the state; and instituting a Public Service Commissioner to reduce ministerial influence on the public sector. ${ }^{324}$ In 1913, the Massey's Government directly intervened in the industrial dispute between waterside workers and their employers, using Defence Department personnel and property to break the strike. They also passed the Labour Disputes Investigation Act tightening up regulations regarding non-registered unions, requiring a three-week conciliation and notification period and a secret ballot of members before any union could legally hold a strike. ${ }^{325}$ The following year, Reform MHR Ernest Lee stated that his Government had "rightly interfered" but that since strikers were left "at liberty to strike and leave their work as long as they liked", the Government's interference did not contravene their commitment to economic freedom - and anyway, he concluded, "the public think that

\footnotetext{
322 Brooking, p.232, 239; Condliffe, p.44-5.

${ }^{323}$ NZOYB 1936, p.305.

324 Bassett, p.123-4.

325 Labour Disputes Investigation Act 1913, ss 7, 9.
} 
the Government was right." 326 Thus in spite of differing rhetoric and intentions, by the outbreak of the First World War the major parties in New Zealand were comfortable interfering in the economy when they judged such actions to be in the public interest. Consequently, the public sector constituted a significant share of the larger economy.

In 1914, New Zealand had an estimated Gross National Product of $£ 94$ million, sent over $£ 26$ million worth of exports and received almost $£ 22$ million worth of imports. Central Government took in $£ 12.2$ million in revenue; slightly less than half of this $-£ 5.9$ million came from taxation, of which the bulk - $£ 3.5$ million - was from customs taxes; the other half coming from charges such as railway and postal fares. ${ }^{327}$ Expenditure out of Government revenue (excluding public works funded out of loans) came to f11.8 million; running the railways, post and telegraph services, and servicing the interest on the public debt, accounted for $f 7$ million of this total. The public debt at this point stood at just under £100 million.

In 1919, Gross National Product had grown to $£ 148.5$ million, exports had increased to almost $£ 54$ million and imports to more than $£ 30$ million. ${ }^{328}$ While the country's overall production and number of imports grew by around fifty per cent over the course of the war, exports more than doubled: high demand for New Zealand produce to feed British troops benefitted the Dominion's exporters, though it also drove up prices. The public debt would exceed $£ 200$ million by the following year, largely due to the cost of the war - estimated at just over $£ 80$ million - being funded via a series of loans. ${ }^{329}$ Government revenue in 1919 had grown to $f 22.4$ million, the majority of this - $f 13.8$ million - now coming from taxation; expenditure had grown to $£ 18.7$ million.

When giving figures for government spending, it is common practise for historians to cite only regular expenditure - expenditure out of the Consolidated Fund. However, given how much of the government's spending was done via the use of loan money - for example, the vital role of spending on public works, which was one of the most important functions of the New Zealand state prior to the First World War, as it developed the country's infrastructure

\footnotetext{
${ }^{326}$ NZPD 1914 vol.168 p.103.

327 NZOYB, 1920, p.328-9, 337.

${ }^{328}$ Rankin, p.14; NZOYB, 1920, p.123.

${ }^{329}$ NZOYB, 1930, p.637. Allen, p.235.
} 
- it is important that we look beyond the Consolidated Fund when telling the story of the growth of the state. This is particular vital for wartime, as the cost of Expeditionary Force was also paid for via loans, using a separate War Expenses Account. Consequently, in the following table I have given figures for government spending from 1914 to 1919, showing "regular" expenditure from the Consolidated Fund, besides spending on public works, the war, and all other spending:

Total Government Expenditure, 1914-19 (all figures in thousands of pounds) (30 $^{330}$

$\begin{array}{lccc} & 1914 & 1915 & 1916 \\ \text { CF } & 11,826 & 12,380 & 12,493 \\ \text { PWF } & 2,761 & 2,737 & 2,583 \\ \text { WEA } & - & 3,272 & 5,938 \\ \text { DA } & 523 & 1,112 & 9,293 \\ \text { OE } & 10,202 & 8,413 & 6,378\end{array}$

$\begin{array}{llll}\text { Total } 1 & 25,312 & 27,914 & 36,685 \\ \text { Total 2 } & 24,789 & 26,802 & 27,392\end{array}$

1917

1918

1919

CF

14,059

15,120

18,674

PWF

1,756

1,402

1,387

WEA

14,391

17,014

21,591

DA

22,072

35,734

37,806

OE

4,612

4,495

4,885

\section{Total 1}

56,890

73,765

84,343

Total 2

34,818

38,031

46,537

Key: CF: Consolidated Fund; PWF: Public Works Fund; WEA: War Expenses Account; DA: Deposit Accounts; OE: All Other Expenditure; Total 1: Gross Total; Total 2: Total, minus Deposit Accounts.

${ }^{330}$ NZOYB: 1914 p.826-32; 1915 p.700-7; 1916 p.570-7; 1917 p.644-52; 1918 p.706-14; 1919 p.734-43. 
Specific mention has been made in the above table of the Deposit Accounts. Expenditure from the Deposit Accounts was made up of expenses "applied to specific purposes under various Acts, collections on behalf of local institutions, and miscellaneous items in suspense." By 1919, the overwhelming majority of expenses from this account consisted of purchases of produce which was then sold to Britain under the Imperial Commandeer, the receipts for such sales then being received into the account; in 1919, expenses were $f 1$ million more than receipts. ${ }^{331}$ I have given a total for government expenses without this particular figure, as while it is important to think of the commandeer as making up a large part of the expansion of government economic activity, the sheer size of spending on these Deposit Accounts, and the fact that receipts so nearly matched expenditure, could be misleading when looking at government expenditure as a whole.

What the table ultimately shows is that, while spending from the Consolidated Fund grew by approximately fifty-eight per cent over the war period, total spending, including the cost of the war, grew by approximately eighty-eight per cent, not including the Deposit Accounts; if the exchange of money involved in the Imperial Commandeer is included, the government's spending grows by more than two-hundred per cent.

Perhaps the most remarkable growth in state revenue and expenditure was in income tax revenues. In 1914, out of total taxation revenue of $£ 5.9$ million, $£ 554,271$ came from income tax and $₫ 767,451$ from land tax. Income tax was collected at $6 \mathrm{~d}$ in the pound on earnings over $£ 300$, rising gradually to $1 \mathrm{~s} 4 \mathrm{p}$ on incomes over $£ 2400$. The war taxation introduced in 1915 raised both income- and land-tax rates, and removed land-taxpayers' exemption to income tax; the following year, after Ward replaced Allen as finance minister, the Government created a special war tax on "excess profits" at a rate of forty-five per-cent on profits made by taxpayers in excess of their averages earnings in the three years prior to the war. The following year Ward conceded the impossibility of accurately defining "war profits" and scrapped the excess profits tax, substituting instead "war tax" increases to all income tax rates, now ranging from $1 \mathrm{~s} 3 \mathrm{~d}$ in the pound on income over $f 300$ to $7 \mathrm{~s} 6 \mathrm{~d}$ on income over $£ 6400$. In 1919 , out of a total of $£ 13.8$ million taxation revenue, land tax had grown substantially to $£ 1.5$ million, but had been overtaken by income tax, at $£ 6.2$ million -

${ }^{331}$ NZOYB 1919, p.736-7. 
a greater than ten-fold increase. ${ }^{332}$ Whereas customs revenues require a record of the movement of commodities being sold, income tax requires the state to keep records of the personal earnings of all taxpayers, more directly linking public and personal accounting.

Customs revenues, on the other hand, had grown relatively slowly, from $£ 3.5$ to $£ 4.1$ million. Since the income tax threshold stayed at $£ 300$ throughout the war, this meant that although taxation per capita rose from 5.5.9 in 1914 to 11.17 .1 in 1919, the lowest wage earners were largely immune to these increases, while the highest earners were now paying far in excess of double their pre-war tax bill. While some part of the spectacular increase in the number of income-taxpayers - from 14,277 in 1914 to 43,280 in 1919 - is due to the doubling of land and income taxes from 1915, the slower but nevertheless significant growth in the number of land-taxpayers - from 40,889 to 53,484 - over the same period, in spite of the absence of farmers in the expeditionary forces, suggests that many of the new taxpayers were the beneficiaries of rising wages pushing their earnings above the tax threshold. ${ }^{333}$

That the public debt doubled due to military expenditure is unsurprising; naturally, this also required a significant increase in Government revenues. The growth of non-military Government expenditure - over fifty per cent - is more remarkable, and suggests that an increase in Government spending necessitated by war created an acceptance of increases to other functions of Government. In fact, a general political consensus was formed that abnormal wartime conditions demanded abnormal Government involvement in all aspects of the economy, from direct control of exports to maximum price regulations and even the provision of some commodities from Government-managed stores. Such expansion was enabled by the fact that although increases to the tax revenues were introduced as measures to fund the war effort, the raising of a series of war loans meant that the increased revenues were initially available for other purposes. An initial loan of $£ 2$ million covered the Dominion's war expenses for 1914, supplemented by another $f 6$ the following year, all raised in London. The following year $£ 16$ million was raised, $£ 11$ million of it on the local market; in 1917 and 1918 further loans of $£ 28$ million and $£ 20$ million were raised on

\footnotetext{
${ }^{332}$ NZOYB, 1920, p.337, 339; 1930 p.628; Evening Post, 4 July 1916, p.6; 2 August 1917, p.6.

${ }^{333}$ NZOYB, 1920, p.338, 340-1.
} 
the local market. Some final borrowing in 1919 meant that a total war loan of $£ 82,245,672$ was added to the public debt, $£ 55,392,895$ of it in loans from domestic lenders. ${ }^{334}$

In $1914, £ 78.6$ million of the public debt was held by British creditors, $£ 18.8$ million with New Zealanders, and $£ 4.3$ million with Australians. In 1920, British creditors at $£ 95.7$ million had been overtaken by domestic creditors, owning $£ 102$ million of the Dominion's debts, while the Australian' share had fallen to $£ 3.4$ million. ${ }^{335}$

The Government's move in 1916 to raise its war loans on the local market (public works loans were also raised locally from 1914) was due largely to London capital being tied up in the United Kingdom's own war effort, but also answered calls to reduce the cost of living by diverting local war profits into paying for the war rather than inflating local prices. Labour and some Liberal MPs at the time urged that such profits ought to be conscripted rather than borrowed on favourable terms which provided investors with high, tax-free rates of interest.

\section{War Profits and Bank Savings}

Hew Strachan has criticised New Zealand's policy of funding the war out of loans, on the grounds that those producers whose wartime profitability allowed them to invest in funding the war effort were thus provided with a second set of war profits:

"New Zealand increased taxes on land and income in 1915, and added an excess profits tax in 1916. It was abandoned in 1917, although higher income now became subject to tax rates of up to a third. by putting the weight less on tax than on war loans offered at very attractive rates of interest, the Dominions enabled those who had already profited from the war to do even better." 336

\footnotetext{
${ }^{334}$ Drew, p.233-43; Allen, p.235.

335 NZOYB 1920, p.346.

${ }^{336}$ Hew Strachan, The First World War, Volume 1: To Arms (Oxford: Oxford University Press, 2001), p.988.
} 
While Strachan footnotes this statement, his references - two official histories from early in the twentieth century - do not advance his argument, and are primarily concerned with Australia. That said, his statement does not actually require a great deal of supporting evidence. We know that the Government raised some $£ 80$ million worth of war loans, of which the bulk - $£ 55$ million - was raised at home. We know that New Zealand's export profits doubled from $£ 26$ - to $£ 54$ million over the course of the war, driven by British military demand for our pastoral produce. These significant war profits could then be reinvested in war bonds - indeed, financial penalties were brought in for those considered profiteers who did not voluntarily invest in war bonds. High rates of return on these bonds ensured that the Government then had to pay further profits to profiteers, out of the pockets of other taxpayers.

And here we get to the shocking unstated consequence of Strachan's picture: because many of the taxpayers of the 1920s were returned servicemen, what Strachan has actually described is a system where exporters profited off a war in which other men were conscripted to fight and die, men who would return home to work and pay taxes partly so that the Government could hand even more money to those who had already profited off the suffering of the men now paying their salaries. This conclusion seems to me to follow on naturally from Strachan's description of the war loan, but it is such a strong statement that we cannot let it stand without rigorous investigation.

Did certain particular groups of New Zealanders, or alternatively the entire country as a single entity, profit off the First World War? And how were these profits paid for? Furthermore, how was the tension between profit and sacrifice dealt with by New Zealand's wartime administration, and what did this mean for the nature of state intervention?

Like Strachan, Paul Baker saw much that rewarded profiteering in New Zealand's war finance. Baker writes that "whether by neglect or design the Government was in effect presiding over a considerable redistribution of wealth between workers (especially those on fixed incomes) and their traditional enemies, farmers and capitalists. Moderates and militants united in a chorus of complaints about prices and profiteering [... which was] especially resented when soldiers (who after all were mainly workers) were 'scandalously paid' and widows' and orphans' pensions 'less than disgraceful'." 
Labour leaders invoked equality of sacrifice in demanding better wages for troops and less capital in the hands of private individuals, while the war was on. Paul Baker quotes Paddy Webb as saying that "To raise the hue and cry that we have no money... is so much hypocrisy", and Baker supports Webb's claim by noting that bank deposits in New Zealand nearly doubled from $£ 27.6$ million in 1914 to $£ 45.6$ million in 1918 (per capita, a rise from $£ 25$ to $f 41) .{ }^{337}$ Yet if we look at banking during the war in greater detail, we see a reasonably even distribution of new wealth.

New Zealand had six banks of issue during the war: the Bank of New Zealand and National Bank of New Zealand - both incorporated by Acts of the New Zealand Parliament - as well as the Union Bank of Australia, Bank of New South Wales, Bank of Australasia, and Commercial Bank of Australia. As these banks did not operate savings accounts until 1964, a record of their deposits represents the success of commercial interests in the Dominion: ${ }^{338}$

\section{Banks of Issue}

\section{Total Deposits Per head of Population}

$\begin{array}{lll}1914 & £ 27,640,507 & £ 25.7 .0 \\ 1915 & £ 31,433,653 & £ 25.11 .10 \\ 1916 & £ 37,757,917 & £ 34.6 .10 \\ 1917 & £ 42,930,713 & £ 39.1 .2 \\ 1918 & £ 45,562,939 & £ 41.6 .2 \\ 1919 & £ 50,489,444 & £ 44.8 .7\end{array}$

While deposits to these banks had remained relatively stable over the previous four years (from $£ 24,968,761$ in 1910 to $£ 25,733,187$ in 1913), they show an increase of over eighty per cent during the course of the war. Meanwhile, the ratio of advances to deposits dropped markedly from 91.25 per cent in 1914 to 71.48 per cent two years later, then rose

\footnotetext{
${ }^{337}$ Paul Baker, King and Country Call: New Zealanders, Conscription and the Great War (Auckland: Auckland University Press, 1988), p.67

${ }^{338}$ NZOYB 1920, p.317
} 
again to 82.08 per cent over another two years before falling to 74.09 per cent in 1919 , suggesting that New Zealand's businesses were taking the war as an opportunity to put money away. ${ }^{339}$ Compare these figures to those of the savings accounts of New Zealanders: ${ }^{340}$

\section{Savings Bank Deposits}

Post Office Savings-Bank

$\begin{array}{llll} & \text { No. of Depositors* } & \text { Total Deposits } & \text { Excess, deposits over withdrawals* } \\ 1914 & 483,262 & £ 11,904,323 & £ 1,301,305 \\ 1915 & 509,085 & £ 13,706,057 & £ 2,411,083 \\ 1916 & 538,072 & £ 15,576,408 & £ 2,618,988 \\ 1917 & 566,351 & £ 17,106,529 & £ 2,645,360 \\ 1918 & 590,205 & f 18,101,105 & £ 3,162,263 \\ 1919 & 630,783 & £ 29,758,447 & £ 3,796,070 \\ \text { *as at 31 December } & & \end{array}$

Five Private Savings-Banks (Year ended 31 March) No. of Depositors* Total Deposits $\quad$ Excess, deposits over withdrawals*

$\begin{array}{llll}1915 & 75,941 & £ 1,358,876 & £ 18,116 \\ 1916 & 78,024 & £ 1,449,938 & £ 122,574 \\ 1917 & 81,900 & £ 1,631,065 & £ 256,951 \\ 1918 & 85,191 & £ 1,764,723 & £ 212,887 \\ 1919 & 89,203 & £ 2,058,360 & £ 282,829 \\ 1920 & 95,427 & £ 3,308,628 & £ 326,741\end{array}$

*as at 31 March

339 NZOYB 1920, p.317.

${ }^{340}$ NZOYB 1920, p.318-9. 
Deposits to both the Post Office- and Private Savings-Banks for the four years of conflict show a slightly slower rate of growth to that of the Banks of Issue - 52 and 51 per cent against 65 per cent. However, substantial increases in savings deposits during the year after armistice give us deposit growth rates of over 100 per cent from 1914, greater than that for the banks of issue, suggesting that private savings saw a greater increase from the post-war boom than did business profits.

Perhaps a more significant picture is painted by the growth of deposits over withdrawals almost two hundred per cent growth for Post Office savings accounts, and over a thousand per cent for savings accounts with the private banks. These real savings contributed to a growth in total credit, which we can compare with assets held by the banks of issue. ${ }^{341}$

\section{Total Assets (Banks of Issue) Total Credit (Post Office Savings Bank) ) $^{342}$}

1914 $£ 32,502,312$

$£ 19,048,029$

1915

$£ 33,209,483$

£22,166,338

1916

$£ 37,015,486$

$£ 25,603,209$

1917

$£ 44,979,615$

£29,196,390

1918

$£ 48,570,126$

$£ 33,418,125$

1919

$£ 48,615,209$

$£ 38,393,130$

Assets held by the six banks grew by just under fifty per cent, while credit held by private individuals saving with the Post Office grew by just over one hundred per cent, though again they owed more of their gains to the immediate post-war boom than did the banks. Nevertheless, these figures suggest that the average New Zealander saving with the Post Office was doing at least as well out of the war boom as were businesses.

But how well did new and small savers do in comparison with private savers who were already well-off? On 31 December 1914, the Post Office Savings-Bank had 483,262

\footnotetext{
${ }^{341}$ NZOYB 1920, p.317-9.

342 Total credit of depositors to the Private Savings-Banks rises from $f 1,876,725$ on 31 March 1915 to $£ 3,557,895$ on 31 March 1920. Due to the different year-end-point used, I have not included these figures. Fortunately, they make up only a tiny proportion of total savings.
} 
individual depositors, with an average of $£ 39$ 8s credit each. By 31 December 1919, there were 630,783 depositors with an average $f 6017 \mathrm{~s}$ each. ${ }^{343}$ This thirty per cent increase in the number of depositors tells us that a great number of people had money to save for the first time. By looking at the Post Office Savings Accounts in greater detail, we can learn more about the accumulation of wealth. ${ }^{344}$

\section{Number of Open Accounts at 31 December (Post Office Savings-Bank)}

$\begin{array}{lllcc}\text { Accounts } & 1915 & 1919 & \text { Increase } & \text { Increase \% } \\ \text { Under } f 20 & 356,968 & 394,280 & 37,312 & 10 \% \\ £ 20-£ 50 & 55,186 & 68,331 & 13,145 & 24 \% \\ £ 50-£ 100 & 36,047 & 56,828 & 20,781 & 58 \% \\ £ 100-£ 200 & 29,759 & 50,111 & 20,352 & 68 \% \\ £ 200-£ 300 & 13,555 & 25,340 & 11,785 & 87 \% \\ £ 300+ & 17,570 & 35,893 & 18,323 & 104 \% \\ \text { Total } & 509,085 & 630,783 & 121,698 & 24 \%\end{array}$

The fact that the number of new accounts opened $(121,698)$ is greater than then increase in the number of accounts with less than $£ 20$ credit plus the total number of accounts with £20-f50 credit at 31 December $1919(105,643)$ tells us that at least 16,000 New Zealanders who had either nothing or less than $£ 20$ in the Post Office Savings Accounts at the end of 1915 had over $£ 50$ four years later. The war and the post-war boom did not only benefit the relatively well off, but increased the savings of a large number of smaller earners.

While these accounts suggest a significant accumulation of wealth, this has to be set against the concurrent inflation of prices. According to Muriel Lloyd Prichard's calculations based on Year Book data, food and rent prices rose by 25 per cent during the war, while minimum

\footnotetext{
${ }^{343}$ For the Private Savings-Banks, the figures for the year ending 31 March are: 75,941 depositors with an average $£ 24$ 14s credit in 1915; 95,472 depositors with an average $£ 37$ s credit in 1920.

${ }^{344}$ NZOYB 1920, p.319.
} 
wage rates rose only 16 per cent. Prichard argues that real wages fell by seven per cent. ${ }^{345}$ Prichard's figures suggest that while the "average" New Zealander's savings grew significantly during the war, this was due not to rising prosperity, but to people making sure they put away a greater proportion of their earnings, necessitated by the uncertain future of a world at war. Wealth accumulated, but the standard of living of most New Zealanders was not rising; this prompted another set of Government interventions, in the form of price fixing mechanisms.

\section{$\underline{\text { Reform's Price Regulations }}$}

The Government's initial economic interventions in the first days of war were determined by the British guidelines in the War Book issued by the Committee of Imperial Defence weeks earlier. In order to prevent a run on the gold deposits of the banks, the Government backed privately-issued paper notes, making them legal currency - a power the Government had taken during the BNZ crisis of the 1890 s. ${ }^{346}$ When a rush on the Post Office Savings Bank did eventuate, the Government temporarily restricted any withdrawals without a week's notice to $£ 2$ per week. ${ }^{347}$

The most important piece of legislation passed during the initial month of the war was the Regulation of Trade and Commerce Act. This Act outlawed trading with enemy nations (later expanded in a Trading with the Enemy Act), provided for a wartime commission of inquiry into commodity prices (the Food Commission), and gave power to the Governor-in-Council to: fix the price of any commodity at or above the current level, with a penalty of up to $f 500$ for any trader selling at prices in excess of those set; prohibit the export of - and/or requisition - any goods; and suspend wage awards. Massey stressed that this was "an empowering Bill", and hoped that many of its powers would not have to be used. ${ }^{348}$ After Liberal and Labour members expressed alarm at the power to suspend industrial agreements, Massey accepted a subclause stating that such powers could not be used to alter the minimum rate of wages in any agreement. ${ }^{349}$ Later in the month, he announced

\footnotetext{
345 Muriel F. Lloyd Prichard, An Economic History of New Zealand to 1939 (Auckland: Collins, 1970), p.264.

${ }^{346}$ Banking Amendment Act 1914, s2; Hawke, p.108.

${ }^{347}$ Everton, p.16.

348 NZPD 1914, vol.169, p.477.

${ }^{349}$ Regulation of Trade and Commerce Act 1914, s 25; NZPD 1914, vol.169, p.484.
} 
the appointment of the Food Commission: three businessmen, a farmer, and a Labouraligned member of the Legislative Council, chaired by a Judge of the Arbitration Court. 350 Ward argued that the Government should go further, and follow Britain's lead in setting up a permanent Board of Trade: "with flexible powers similar to that which they have got in the Old Country." 351

At the same time as it appointed the Food Commission to report on general price levels, the Government responded to an immediate twenty per cent wartime increase to the price of wheat by prohibiting exports. At the end of September, the Food Commission recommended fixing the maximum price of wheat at $5 \mathrm{~s} 3 \mathrm{~d}$ per bushel; the Government instead fixed the maximum at 4s $9 d$, causing millers who had already bought at higher prices to complain that they were being forced to sell at a loss. ${ }^{352}$ The Government relented by the end of October and raised the maximum to that recommended by the Commission, but millers were still reluctant to part with their supplies, while wheat sellers frequently received illegal prices above 6s. In January, after importing Canadian wheat for $6 \mathrm{~s} 3 \mathrm{~d}$ per bushel, the Government again raised prices, to $5 s 9 d$, to recoup some of their losses. ${ }^{353}$ The government's price fixing plan had failed to prevent further rises to the price of wheat, had upset farmers, and resulted in the taxpayer effectively subsidising imports, and on 8 February 1915 the price fixing scheme was scrapped. Labour Member of the House of Representatives Bill Veitch complained that the flour merchants had done what the "Red Feds" did in telling the Prime Minister "We do not like this law; we do not obey it, and we do not intend to obey it", and that Massey had said "Very well, gentlemen, if the law does not suit you then I will alter it." 354

The Government had also implemented a ban on all wool exports except to Britain and the Empire from October 1914, as the Imperial Government had indicated it required all the wool it could get. ${ }^{355}$ In July 1915, the Government banned butter exports due to a recent price spike; as most of the season's export butter had already been sent, this prohibition

\footnotetext{
350 NZPD 1914, vol.169, p.650-1.

${ }^{351}$ NZPD 1914, vol. 172, p.135.

352 Evening Post 30 September 1914, p.6; 2 October 1914, p.8; 3 October 1914, p.3.

${ }^{353}$ Evening Post 20 October 1914, p.8; AJHR 1915, B-6, p.xv; D.B Copland, Wheat Production in New Zealand (Auckland: Whitcombe and Tombs, 1920), p.267-8.

354 NZPD 1916, vol. 175, p.76.

355 NZPD 1914, vol.171, p.822-4.
} 
gave the appearance of an intervention without significant consequences for producers. ${ }^{356}$ Prices fell in August, and the ban was lifted in September.

In January 1915, the Government struck a deal with New Zealand's monopoly sugar provider, the Colonial Sugar Refining Company, who two years earlier had been found guilty of exploiting their position. Their agreement set the price of sugar at $£ 20$ a ton, rising to $f 22$ 10 s by the end of the war, about half of the international market price. The agreement saved New Zealand consumers an estimated $£ 58,000 .{ }^{357}$ As setting sugar-prices did not involve the Government in regulating a market, the success of the scheme depended entirely on the goodwill of the Colonial Sugar Refining Company. Sutch and Everton both regarded this gentlemen's agreement as the most successful of the Government's price controls. ${ }^{358}$

\section{Coalition Government and Imperial Commandeer}

By the middle of 1915, the Reform Government had implemented a number of export controls, one unsuccessful and abandoned attempt at direct price control, and a price agreement with a monopoly supplier. Massey did not appear keen to embark on further price fixing attempts: where Ward appealed to British sentiment in asking for a Board of Trade, the Premier declared that no one could "deny the authority of Mr Asquith," the British Prime Minister, when he said that Germany's price controls has caused "evasion, confusion and frustration". ${ }^{359}$ In late 1914 Massey had informed Parliament that while the "war period" made it especially "the duty of the Government... to do everything it possibly can to prevent exploitation by unscrupulous traders," he hoped exporters would nevertheless take advantage of the high wartime commodity prices to bring in as much capital as possible. ${ }^{360}$

1915 brought structural changes to both the makeup of the New Zealand Government and to the country's external trade relations, changes that challenged Massey's desire to resist

\footnotetext{
${ }^{356}$ Round Table vol.5 p.252; Everton, p.145.

357 AJHR 1920-1, H-44, p.14.

358 Sutch, p.45; Everton, p.239-40.

359 NZPD 1915, vol.172, p.169.

${ }^{360}$ NZPD 1914 vol.171 p.513
} 
further attempts to fix domestic prices: the imperial export commandeer, and the national coalition. The former eventually regulated the export of all the Dominion's major pastoral commodities under an agreement between the New Zealand and Imperial Governments to sell and buy all or a part of the export crop at set prices. Farmers accepted prices set well above pre-war levels but generally below London market prices, and in return received a state-backed assurance that their produce would eventually receive shipment in spite of the interruptions to trade created by German Naval scares, the loss of refrigerated shipping space when vessels were commandeered for troop transport, and competition from South American suppliers with safer, shorter shipping routes. ${ }^{361}$ The agreement also guaranteed credit to pay farmers backed on the assurance that their produce would eventually reach the market.

The Department of Imperial Government Supplies began working on the $3^{\text {rd }}$ of March, 1915, with the requisition of all frozen meat exports. The Department took all meat and a third of all cheese that year, and from 1916 until 1920 all frozen meat, cheese and wool. From 1917 to 1921 they also requisitioned all butter exports. From the $3^{\text {rd }}$ of March 1915 until the $31^{\text {st }}$ of August 1922, the Department organised the payment of $£ 160$ million to suppliers: $f 53$ million for meat, $£ 51$ million for wool, $£ 21$ million for cheese, $£ 17$ million for butter, and smaller amounts for dried and condensed milk, scheelite, sheep skins and cattle hides. ${ }^{362}$ The commandeer controlled roughly fifty-five per cent of the Dominion's total export trade f290 million - from 1 July 1915 to 30 June 1922.

The Dominion shipped just over $\mathrm{f} 25$ million worth of goods to Britain every year for the first three years of the war, falling to $f 18$ million in 1917-18 due to the shipping crisis, compensating with a spike to $£ 44$ million in 1919 before settling around $£ 36$ million for four years following. ${ }^{363}$ Britain's share of New Zealand's export trade rose almost imperceptibly from 81 to 82 per cent from 1914 to 1917, fluctuated between 64 per cent in 1918, 82 per cent in 1919, and 74 per cent in 1920, then settled in the mid 80 s.

The fluctuations within the overall growth of the New Zealand-Britain trade relationship reflect wartime shipping shortages: the sharp fall in 1917-18 coincides with Germany's

\footnotetext{
${ }^{361}$ Evening Post 5 January 1915, p.6; 15 February 1915, p.2.

362 NZOYB 1923, p.304-8.

${ }^{363}$ NZOYB 1930, p.302.
} 
unrestricted U-boat campaign. After the initial interruptions to trade due to the commandeer of ships to move the first wave of Australasian troops, the British Government requisitioned all insulated cargo space trading between Australasia and the Home Country. ${ }^{364}$ During the U-boat campaign in 1917 , stores of pastoral produce filled up coolstores in New Zealand while the British kept ships to the safer American routes. ${ }^{365}$ These naval scares and the Imperial Government control of shipping company property, following on top of the industrial disputes just prior to the war, added to the uncertainty of New Zealand's independent shipping owners. British Giant P. \& O. bought controlling interests in the New Zealand Shipping Company in 1916 and the Union Steam Ship Company in 1917. The former had been managed from London since the 1890s, while the manager of the latter, former MHR James Mills, had retired to London in 1906. ${ }^{366}$ By the end of the war, this already British-dominated service, absolutely essential to New Zealand's economic specialisation around long-distance export trade, was entirely in British hands. The Farmers Union pressed the Government to investigate a state shipping line. ${ }^{367}$ Massey stated that while he was "not a State Socialist in the ordinary sense of the term", nevertheless he supported the idea of a state shipping line, even accepting that it would be a "socialistic" policy. ${ }^{368}$ But the expense of establishing a shipping line realistically able to compete with the British firms would have been overwhelming, and the idea was not pursued.

After the formation of a National Government in August 1915, Ward, as Finance Minister, was able to supplement the Regulation of Trade and Commerce Act with a potentially permanent Board of Trade, which had seven powers to "investigate and report", it's findings then going to Cabinet as before. ${ }^{369}$ But Massey, as Minister of Industries and Commerce, was made chair of the Board, and as long as he and Ward remained in New Zealand the Board was reluctant to pursue further price controls, although he reinstated the off-season ban on butter exports. ${ }^{370}$ When Massey and Ward left for England in August 1916, Liberal Cabinet Minister William MacDonald took Massey's place as chair of the Board. After two

\footnotetext{
${ }^{364}$ Evening Press, 2 April 1917, p.8.

${ }^{365}$ AJHR 1921, H-38, p.7; Evening Press, 15 April 1915, p.8; 17 August 1918, p.4.

${ }^{366}$ Evening Press, 4 July 1916, p.6; 6 July 1916, p.2; Hawke, p.87; Gavin McLean, "Mills, James," in Dictionary of New Zealand Biography, Te Ara - the Encyclopedia of New Zealand, updated 20-Nov-2013, URL:: http://www.TeAra.govt.nz/en/biographies/2m48/mills-james.

${ }^{367}$ Condliffe, p.240.

368 NZPD 1916 vol.177 p.629.

${ }^{369}$ Cost of Living Act 1915, s 6; NZPD 1915, vol 174, p.751.

${ }^{370}$ Everton, p.153-4.
} 
months under MacDonald, the Board in established a butter price stabilisation fund, paid out of export receipts to subsidise local sales. In January they used the operation of one Auckland merchant to establish State-funded butcher shops to compete with the Auckland Master Butchers' Association. The Government butcheries successfully forced the Butchers' Association to reduce their prices to the level demanded, but the scheme lost $£ 1053$ and was closed when Massey returned at the end of the year, calling it a failure. ${ }^{371} \mathrm{He}$ introduced a scheme to supply butchers, who agreed to certain maximum prices, with meat from Government stores.

In February 1917, the Board of Trade introduced price controls on wheat, at the same time advocating the need to encourage local production. Juggling these two demands meant paying farmers a sufficiently high sum to grow wheat, and subsidising cheap flour for consumers. In mid-1917, the Government lost $£ 6,700$ when it purchased Australian wheat for more than prices it had set for the domestic market. ${ }^{372}$ Such a system could only be implemented with central control of the wheat trade, and in December 1917 private dealings in wheat were prohibited. ${ }^{373}$ The wheat controls were removed in 1923 , but as the Government continued juggling import bans to encourage production and bulk import purchases to avoid shortages, growers and millers pressed the government into reimposing control of supplies. ${ }^{374}$ Sutch wrote that the cost of trying to protect local growers was artificially low prices, while Everton wrote that the cost of trying to artificially lower prices was alienating growers. ${ }^{375}$

The Government's concern over wheat prices stemmed from two major factors. First, wheat was considered an essential item of consumption; and second, seasonal variations and the low profitability of the crop meant that shortages were an ongoing feature of domestic wheat production. These factors may have been exacerbated by the war, but they constituted an ongoing problem, so that when the Government used wartime powers to deal with the problem, they inevitably made it hard to extricate themselves from the system of control once the war was over.

\footnotetext{
${ }^{371}$ NZPD 1918, vol. 182, p.254; Sutch, p.101.

372 AJHR 1917, H-44, p.3-5; AJHR 1918, H-44, p.3.

${ }^{373}$ Evening Post 22 December 1917, p.5; Sutch, p.101.

${ }^{374}$ Everton, p.121-6.

${ }^{375}$ Everton, p.134; Sutch. p.120.
} 
Their other major attempt at commodity price control, the butter fat levy, was more directly related to the economic interruption of the war. Like wheat, butter was considered an essential part of consumers' diets. But unlike wheat, butter was part of a successful export trade, and although not initially part of the commandeer, butter was effected by the commandeer and high prices for cheese, as farmers sought to sell their milk for cheese instead of butter production: cheese production had overtaken butter production two years before the war, and continued to dominate the dairy trade. ${ }^{376}$ In the first years of war, lack of shipping space for butter exports and the two brief export bans ensured that the domestic market was reasonably well supplied, although before departing the country Massey had expressed a desire to keep the price down. ${ }^{377}$ MacDonald took over the chairmanship of the Board of Trade just as prices overtook the level Massey had indicated as ideal. The Board attempted to fix domestic butter prices, but faced the prospect of suppliers abandoning the domestic market, and could not, under the powers of the Regulation of Trade and Commerce Act, set maximum export prices outside of the commandeer. ${ }^{378}$ Their response was to apply the power to ban exports, but then allow exports provided exporters paid a small levy, which would then be used to "equalise" the earnings of producers for the domestic market who were forced to keep their prices below a set maximum.

This "butter fat levy" scheme was enacted by Order in Council in October 1916, when Parliament was not sitting. Almost immediately, two dairy companies challenged the levy system in front of the Supreme Court: arguing that the levy was a "tax" on exporters, and that, as it had not been approved by Parliament, the levy constituted taxation without representation, and thus breached the Petition of Right. ${ }^{379}$ The Solicitor General, John Salmond, argued that the "national emergency" of war meant that the Government had to possess "despotic" power, including the ability in the War Regulations Act to "override by way of regulations any Act on the Statute Book." He also argued that the levy was not a tax, "but the price you pay for a license" to export. ${ }^{380}$ The Chief Justice, Robert Stout, found for the plaintiffs, concluding that since the levy was treated "as money payable to the Crown" it

\footnotetext{
376 NZOYB 1914, p.612.

377 Evening Post 6 October 1916, p.6; NZPD 1919, vol. 185, p.1416.

378 AJHR 1917, H-44, p.5.

379 "The Taratahi Dairy Co., and Mangorei Dairy Co. v. Attorney General": N.Z.L.R. 1917, vol.36, p.1-2.

${ }^{380}$ N.Z.L.R. 1917, vol.36, p.10.
} 
was "in effect, a tax" and was therefore "unconstitutional and illegal". ${ }^{381}$ However, the two other Justices on the panel concluded that the butter fat levy was not in fact a tax, and found in favour of the Crown. ${ }^{382}$ In spite of the Government's defence resting on the levy not constituting a tax, MacDonald would later describe it exactly as such when arguing for its success. ${ }^{383}$ Over the 1916-17 and 1918-19 seasons, the Government collected and redistributed $£ 309,198$ under the levy scheme. ${ }^{384}$

In November 1917, the New Zealand Government successfully convinced Britain to accept New Zealand's butter exports as part of the Imperial Commandeer. The export price agreed upon, while far above the pre-war price, was significantly below that paid on the London market for European and American butter. Producers argued that by agreeing to such prices, they were effectively subsidising the price of butter to the British consumer, a "patriotic gift" to the Mother Country. ${ }^{385}$ However, since butter was not requisitioned for military use, by ensuring shipping and advancing payment the British government did producers a favour in return for this "gift". ${ }^{386}$ Setting export prices below the market rate also helped the New Zealand Government: since export prices were now much closer to the maximum price fixed for the domestic market, they were initially able to resist applying the levy for to that season's exports, although the Imperial Supplied Department agreed in mid1918 to administer the equalisation fund for the $1917-18$ and $1918-19$ seasons. ${ }^{387}$

The butter-fat levy remained unpopular with dairy farmers, and after the collapse of the National Government in August 1919, Reform bowed to farmer pressure by agreeing to fund the subsidy of local butter prices out of the Consolidated Fund, at an estimated cost of $£ 300,000$ per year. ${ }^{388}$ Massey assured parliament that he had "had absolutely nothing to do with" setting up the export levy; that the scheme was entirely MacDonald's doing while

\footnotetext{
${ }^{381}$ N.Z.L.R. 1917, vol.36, p.14, 22.

${ }^{382}$ N.Z.L.R. 1917, vol.36, p.30, 32. See further discussion in the Justice chapter of this thesis, below.

${ }^{383}$ Evening Post 28 November 1916, p.8;

${ }^{384}$ Sutch, p.54.

${ }^{385}$ Evening Post 11 October 1917, p.4; 27 October 1917, p.8; 27 February 1918, p.10; 13 June 1918, p.4; Everton, p.191.

386 Indeed, in spite of claims from many in New Zealand that the supply of produce to Britain was part of the war effort, the inefficiency of importing from distant New Zealand rather than the Americas meant that, on the contrary, the commandeer was more a reward to the Dominion for the supply of troops: James Watson, "The Tyranny of Distance: New Zealand Meat Exports and the First World War," (Conference Oral Presentation: Presented at "Rethinking the First World War," Victoria University, November 2013).

${ }^{387}$ Evening Post 24 July 1918, p.8; 25 July 1918, p.6.

${ }^{388}$ AJHR 1919, I-12, p.xi.
} 
Massey was away, that he had been "somewhat surprised to hear of its introduction and "promised to take it off" as soon as he returned. ${ }^{389}$ MacDonald, however, insisted that the Prime Minister had formalised the agreement with the Department of Imperial Supplies. ${ }^{390}$ Massey's attempts to deflect responsibility for the scheme did not save Reform from feeling the ire of Taranaki farmers at the 1919 elections. ${ }^{391}$ The Imperial requisition of butter ended in March 1921, and in August the Government ceased setting domestic prices and subsidising them out of Government revenues. ${ }^{392}$

Sutch wrote that the "Butter-Fat Levy was an effective means of keeping the local prices low without paying any subsidy from the Consolidated Fund, and it worked well from the administrative point of view", but that the end of the Coalition Government meant producers were able to sway the Prime Minister into accepting a subsidy from Government revenues which, while "much fairer from a commercial standpoint", was unfair on other industries effected by price-fixing who received no subsidy. Sutch believed that the price controls had kept prices down and allowed the Government to more effectively combat "monopoly tendencies", but that control was weakened by "departmental decentralisation". ${ }^{393}$ Everton, on the other hand, concluded that attempts to control the price of butter were "poorly thought out", caused "divisions and discord", and were "unnecessary given the high level of butter consumption amongst New Zealanders and the small savings the intervention aimed to effect." Everton believed that when Massey replaced the levy with subsidisation out of the Consolidated Fund, he made the scheme "fairer and simpler." 394

Although Sutch and Everton agreed on the effectiveness of the sugar price agreement and the failure of the wheat protections and controls, their conclusions regarding the butter levy reflect divergent ways of looking at commodity markets. The levy did reduce the price of a commodity regarded as essential to the public health; the original levy managed to reduce costs without burdening the taxpayer, but at some political cost to Reform; the government subsidy reassured farmers, at a substantial cost to the wider taxpaying community.

\footnotetext{
389 NZPD 1919, vol.185, p.1415, 1421.

${ }^{390}$ NZPD 1919, vol.185, p.1422.

${ }^{391}$ Everton, p.217.

392 Sutch, p.60.

${ }^{393}$ Sutch, p.62-4.

${ }^{394}$ Everton, p.220-1.
} 


\section{Later Impacts of the Commandeer: The Military-Agrarian Complex}

Although the commandeer and war-time price fixing schemes gradually came to a halt in the early- to mid-1920s, Government had set a precedent for the central organisation of the pastoral export industries which was popular among producers. The Board of Trade Act 1919 extended the Board's powers, although the Massey Government was reluctant to use them and its activities were scaled down in $1922 .{ }^{395}$ On the other hand, the Meat Export Control Board and Dairy Export Control Board, founded in 1922 to 1923 to allow producers to direct their trade with Britain, made significant attempts to reinforce the level of central control experienced during the war. The Meat Board held the "widespread support of producers" and successfully regulated the grading and marketing of produce. ${ }^{396}$ The Dairy Board attempted to take control much further: in 1926 the Board compelled all producers to submit to regulated prices and conditions, and attempted to force the London market to agree to its terms. The Board failed to stem price fluctuations the following year, and the experiment was abandoned, having cost the Board the good will of both producers and buyers. ${ }^{397}$

The First World War interrupted regular trading patterns, and placed the majority of New Zealand's export trade under direct Government supervision. Such an abnormal situation inevitably impacted upon the cost of living, and the Government had to take responsibility for its effect on prices by extending market controls. Its various attempts at control lasted beyond the end of the war, and created precents for greater state economic intervention. However, the mixed success of these measures, combined with ongoing political reluctance to experiment unless forced to by public pressure, ensured that the state often did not use, or used but later abandoned, the extraordinary emergency powers it gave itself.

As the centralised economy of the war was directed primarily towards supplying Britain with wartime needs, economic interventions boosted the strength of the Dominion's Imperial trade. However, this link was interrupted both by shipping shortages and by the Dominion Government having to look to local creditors to fund its public debt. Had the former problem led to a real attempt at a state shipping line, the effect of the war on New

\footnotetext{
395 Bassett, p.132-5.

396 Brooking, p.237.

397 Ibid; Hawke, p.100.
} 
Zealand's economic independence could have been significant. But the cost of such an investment was never realistic, and New Zealand's economy in the 1920s was even more firmly based around an Imperial relationship than it had been prior to the war.

During the debate over conscription, some Members of Parliament referred to the New Zealand's pastoral exports as part of the country's war effort - even as a more important contribution than the act of sending soldiers. ${ }^{398}$ However, as James Watson has shown, devoting shipping to New Zealand - instead of Argentinian - meat was an inefficient use of resources for the British Government, owing to the increased distance and threat from German U-boats. ${ }^{399}$ It can thus be argued that the commandeer was as much, perhaps more so, a reward for New Zealand's contribution of men, as a contribution to the war. I propose, then, that we consider New Zealand's export of both troops and produce to Britain as constituting a "military-agrarian complex": pastoral exports to Britain were a contribution to the war effort, albeit an inefficient one, and they made up the overwhelming majority of New Zealand's export trade. These exports provided the foundation of the New Zealand economy, funding the Government's war efforts; meanwhile, the Dominion's continued supply of men to fight in the trenches ensured Britain would continue to purchase New Zealand's exports in spite of ongoing shipping shortages and risks. This feedback loop between military contributions and farming profits suggest that New Zealand during this era operated a military-agrarian complex, similar in nature to Eisenhower's conception of the military-industrial complex. Primary industries and defence policies operated hand-in-hand in a mutually beneficial relationship; and even if Strachan's description of farming profits as war profits need to be moderated by the fact that these war profits trickled out into the wider community, the link between troop exports and produce exports remains a significant fact of the wartime economy, and a clear demonstration of how the war tightened links between Great Britain and New Zealand even as it strengthened the power and increased the size of the Dominion state.

\footnotetext{
${ }^{398}$ NZPD 1916, vol.175, p.517, 533, 881.

399 Watson, "The Tyranny of Distance."
} 


\section{$\underline{\text { Rent Controls }}$}

The final piece of price-controlling legislation to consider is the restriction placed on rental properties in the War Legislation Amendment Act 1916, and subsequently amended in the War Legislation Act 1917. Rents over most of the country actually fell during the war, due partly to the absence of so many renters overseas. In May 1915, economist Dr. James Mcllraith claimed that overall, the cost of living had risen approximately nine per-cent since the previous August, but that house agents had to reduce rents by "roughly" ten per-cent over the same period. ${ }^{400}$ Subsequently, Government Statistician Malcolm Fraser argued that falling rentals masked the true rise in the cost of living. ${ }^{401}$ However, in Wellington - which already had relatively high rents, due to its concentrated population, lack of easily accessible suburbs and high proportion of renters - the cost of renting did increase following the outbreak of war, due largely to the concentration of training camps (Trentham and Featherstone) in the area. ${ }^{402}$ Citing a "wholesale raising of rent in Wellington", John Payne introduced a Rent Bill in May in 1916, based on a similar Act passed by the British Government restricting rents there to the level at which they stood on 3 August 1914, except for the cost of any structural alterations made by the landlord. ${ }^{403}$ Wellington Labour MP Alfred Hindmarsh stated that Wellingtonians were being "made to suffer in a time of war" by extortionate landlords taking advantage of people who had "come down to live close to their friends in camp", and argued that "if the Imperial Government has thought it necessary to legislate in regard to this matter surely [...] New Zealand will not be behind in dealing with the subject." 404

Although Payne's Bill did not become law, the Government introduced its own rent controls two months later, within the War Legislation Bill, in Massey's words "on exactly the same lines as the English Bill". This legislation would make it impossible "for the landlord to sue for the difference between the rent charged prior to the outbreak of the war and any increase which may have been made since that date", except where the increase covered the cost of structural alterations. Massey stated that the Bill would not have been necessary

\footnotetext{
400 Evening Post, 1 May 1915,

${ }^{401}$ Malcolm Fraser, An Inquiry Into Prices (Wellington: Government Printer, 1920), p.112, 126.

402 Everton, p.303, 316-7.

403 NZPD, vol.175, 11 May 1916, p.25.

${ }^{404}$ NZPD, vol.175, 11 May 1916, p.25-6.
} 
but "for the state of things in Wellington" owing to the military camps, yet the restriction was applied across the whole country regardless. ${ }^{405}$ Payne criticised the Bill for not being made retrospective to the beginning of the war (unlike the English War Rents Act). ${ }^{406}$

Others criticised the Bill from the opposite direction, arguing that it was unfair on landlords who were letting properties at low rates on the outbreak of war, and had raised their rents merely to cover costs and make a reasonable profit. These critics asked the Government to amend the Bill to set a maximum "fair return" on property investment. ${ }^{407}$ The Bill was subsequently amended to allow landlords to raise rents to a maximum equal to eight per cent of the capital value of the property. ${ }^{408}$ Where the landlord and tenant were in dispute about this value, either could apply to a Stipendiary Magistrate to have it determined, with the Magistrate dividing the cost of the inquiry between the tenant and landlord "in such manner as the Magistrate may direct." 409

The possible cost of such an inquiry put most tenants off applying for a determination of the capital value, with only one such application (decided in favour of the tenant) in the first twelve months. ${ }^{410}$ Consequently, the Hindmarsh appealed to the Government in September 1917 to allow some outside authority to determine the capital value of a rental property without cost to the tenant. ${ }^{411}$ The Government accepted the necessity for such an amendment, allowing any Inspector of Factories to apply to a Magistrate on the tenant's behalf, and allowing the Magistrate to request a valuation of the property from the ValuerGeneral. ${ }^{412}$ From 1 November 1917 to 31 March 1918, Inspectors of Factories received 102 such applications from Wellington tenants: eighty were settled out of court (34 in the tenants' favour) and eight were still unresolved; of the fourteen settled in court, five were decided in favour of the tenants. ${ }^{413}$ While less than half these applications were found in the tenants favour, showing that rents were not as extortionate as many believe, nevertheless the overwhelming increase of applications for value-determination (both successful and

\footnotetext{
405 NZPD vol.177, 25 July 1916, p.394-5.

${ }^{406}$ NZPD vol.177, 25 July 1916, p.411.

407 NZPD vol.177, 25 July 1916, p.405-6, 416.

${ }^{408}$ War Legislation Amendment Act 1916, s6.

${ }^{409}$ War Legislation Amendment Act 1916, s7.

${ }^{410}$ Everton, p.325-6.

${ }^{411}$ NZPD vol.180, 25 September 1917, p.360-1.

412 War Legislation Act 1917, s19-20.

${ }^{413}$ AJHR 1918, H-11, p.8.
} 
otherwise) under the amended legislation justified Hindmarsh's position. The following year, Inspectors received 234 applications (148 in Wellington), and found the increased rents unjustified in 108 cases. However, --- also reflected that the eight per-cent restriction had "undoubtedly [...] had the effect of discouraging the building of houses, thereby accentuating the very difficulty that the rent-restriction law was designed to overcome", and advocated the Government overcome this difficulty by building more homes under the Workers' Dwellings Act 1905. ${ }^{414}$

Exactly to what extent the rent-restricting legislation stymied building and accentuated the problem is difficult to determine. A. J. Everton, who took a markedly anti-interventionist position, noted that "other factors besides rent-fixing" tended to "depress the housing market, and thus the available stock of dwellings for letting", such as the wartime "shortage of labour and materials". Nevertheless, Everton argued that in spite of such qualifications "there is enough evidence to suggest that the regulations, which the judiciary was inclined to apply zealously in favour of tenants, had a marked effect on the decline in the growth of rental accommodation which took place during the war period, and even more so afterwards as the 'temporary' war measure was renewed each year before finally finding a permanent place on the Statute Book as the Fair Rents Act of 1936." 415

Much of Everton's evidence is in fact conjecture: the eight per cent provision would "probably" have been enough on its own "to lessen investment in this sector of the housing market." ${ }^{416}$ Remarking on a 1918 law prohibiting landlords from ejecting tenants from their property - even when they wanted it for their own use - when that tenant was a soldier (or their wife), Everton argued that "the overall effect was probably to deter investors from entering the field and to persuade some landlords to abandon it." ${ }^{417}$ Elsewhere, Everton states that the eight per cent returns on property "probably [...] did not compare favourably which those which could be got" from other investments, such as war loans guaranteeing a return of 4.5 per cent free of income tax. ${ }^{418}$ Everton also concedes that many landlords might have withdrawn from the market in order to sell while prices were high, but argues

\footnotetext{
${ }^{414}$ AJHR 1919, H-11, p.10-11.

415 Everton, p.307.

${ }^{416}$ Everton, p. 325.

${ }^{417}$ Everton, p.331.

${ }^{418}$ Everton, p.333-4.
} 
that it was "unlikely" so many would have sold "had it not been for the rent restrictions", as high house prices should have meant high rents. ${ }^{419}$ The number of complaints investigated by the Inspectors of Factories "must have played some part in the decline in the stock of rental housing". ${ }^{420}$ Finally, Everton concedes that it is "difficult to reach a firm conclusion about the extent of any downturn in house-building, and the degree to which this was caused by rent restrictions" since "the depressing effect that higher costs had on housebuilding" makes it "almost impossible to evaluate the part played by the rent legislation". ${ }^{421}$ Furthermore, "the main centres except Wellington" - which lost its large training camps with the peace - "experienced a sharp rise in rent levels between 1919 and 1921" in spite of the legislation. ${ }^{422}$

While this amount of conjecture and qualification makes it tempting to doubt Everton's initial claim that there is "enough evidence" to show the legislation had such a "marked effect" on the decline of rental accommodation relative to owner-occupied housing, I agree with him that the laws of supply and demand alone suggest that the legislation played at least some part in this decline, but would stress that the level of this impact is unknown.

Everton's most solid evidence for the negative impact of rent-fixing is in "the dramatic fall between 1916 and 1921 in both the proportion of the population housed in rental accommodation and in the actual number of dwellings to rent", citing a decline of 4,075 rented dwellings during this time "while during the same period the overall number of dwellings rose by $23,215 " .{ }^{423}$ Everton notes that the 5,749 homes purchased under the Advances the Workers Act (and similar schemes) more than account for the fall in rental dwellings, but also notes that this number is less than the 6,436 such homes purchased in the previous five years. ${ }^{424}$

Where Everton uses the decline in number of renters as indicating a flaw in the Government's price-fixing legislation, Miles Fairburn uses this same decline as a positive aspect of the Reform Party's effect on working-class New Zealanders:

\footnotetext{
${ }^{419}$ Everton, p.341.

${ }^{420}$ Everton, p.343.

421 Everton, p.334-5.

422 Everton, p.342.

${ }^{423}$ Everton, p.338; figures taken from NZOYB 1924, p.752.

${ }^{424}$ Everton, p.339.
} 
Belying its reputation for selective inertia, the Massey Government had an activist social policy which centered on the promotion of home ownership and secondary education opportunities [...] thousands of ex-servicemen who had been without property before the war, obtained cheap urban housing finance through the government's open handed administration of the 1915 Discharged Soldier Settlement Act. (The success of this has been obscured by the failure of farm settlement scheme under the same act). An even greater number of workers were tempted to buy their own homes through Reform's vigorous implementation of the 1906 Advances to Workers Act, which allowed wage and salary earners below a certain income to borrow money from the state on favourable terms [...] So active was the state in the promotion of home ownership that it became the largest mortgagee in the country. In an average year it lent a sum equivalent to about two-thirds of the total value of new urban housing. With all this stimulation the proportion of wage and salary earners householders who owned their houses climbed from $36 \%$ in 1916 to about $50 \%$ in $1926 .{ }^{425}$

While the Reform Party's major policy platform in 1912 was providing freehold titles to Crown leaseholders, this did not mean they rejected state investment in the property market. However, they did initially reduce their involvement. With the Advances to Workers Act 1906, the Liberal Government provided low-interest loans to make home-ownership affordable to low-income workers. Although Reform continued this scheme, updating the legislation with the State Advances Act 1913, the number of loans they authorised fell from 1,900 in 1912 to 1,254 in 1913 and 1,200 the following year, with the total amount advanced falling from $£ 543,840$ in 1912 to $£ 272,860$ in 1914 . The arrival of war, which of course reduced the number of men seeking to purchase homes and redirected government spending, while at the same time increasing the cost of building materials, caused these figures to fall to only 372 loans authorised in 1919 and $£ 87,590$ advanced. ${ }^{426}$ The sharp fall in the Government's authorisation of these loans in even the pre-war Reform era

\footnotetext{
${ }^{425}$ Miles Fairburn, "The Farmers Take Over," in Keith Sinclair ed. The Oxford Illustrated History of New Zealand $2^{\text {nd }}$ ed. (Auckland: Oxford University Press, 1996), p.205-6.

${ }^{426}$ J.M. Robertson, 'The Housing Problem in New Zealand', (Master of Commerce Thesis, University of New Zealand, 1941), p.55.
} 
contradicts Fairburn's description of their "vigorous implementation". Although the Soldier Settlement Scheme which led the post-war loan boom was a National Government Act, it was strongly supported by Massey (though he had initially promoted a more careful, limited scheme), but it is relevant to note that, like Reform's increases to pensions, their actions in this area were primarily directed at rewarding war service, rather than at expanding the state's commitment to civilian support.

\section{$\underline{\text { The Soldier Settlement Scheme }}$}

One of the most significant - and certainly the most historiographically controversial - of the New Zealand Government's economic interventions arising from the First World War was the soldier settlement scheme for loaning money to returned servicemen, to help them settle land: over 22,000 such men were settled, approximately 10,000 on farms, and the remainder on urban and suburban sections. ${ }^{427}$ Over 10,000 British soldiers were also settled in New Zealand, following the British Empire settlement campaign of Henry Ryder Haggard.

Historical debate has focused almost exclusively on the settlement of New Zealand soldiers on farms, with most historians arguing that the scheme was a failure: that inexperienced men were placed on overvalued land and abandoned to forfeit or walk off their farms after a series of economic slumps ending in the Great Depression. Nicholas Boyack and Jane Tolerton called the Government's management a disastrous betrayal of the men; Miles Fairburn claimed it was "one of the greatest disasters in social planning" in our history. ${ }^{428}$ The "Bridge to Nowhere" over Mangapurua Stream in Whanganui National Park has come to symbolise this failure: the bridge is left standing without any approaching roads as all forty soldier farmers deserted the area by the end of $1942 .{ }^{429}$ In a 1992 thesis, Ashley Gould

\footnotetext{
${ }^{427}$ Ashley Gould, "Soldier Settlement in New Zealand After World War I: A Reappraisal," in Judith Smart and Tony Wood eds., An Anzac Muster: War and Society in Australia and New Zealand 1914-18 and 1939-45 (Clayton, VIC: Monash Publications in History, 1992), p.117.

${ }^{428}$ Nicholas Boyack and Jane Tolerton, In The Shadow of War: New Zealand Soldiers Talk About World War One and Their Lives (Auckland: Penguin Books, 1990), p.245-7; Miles Fairburn, "The Farmers Take Over," in Keith Sinclair ed. The Oxford Illustrated History of New Zealand $2^{\text {nd }}$ ed. (Auckland: Oxford University Press, 1996), p.205.

${ }^{429}$ Arthur P. Bates, The Bridge to Nowhere: The III-Fated Mangapurua Settlement (Wanganui: Wanganui Newspapers, 1981); Gavin McLean, "The 'Bridge to Nowhere'," URL: http://www.nzhistory.net.nz/media/photo/bridge-nowhere, (Ministry for Culture and Heritage), updated 8Oct-2014
} 
criticised the use of this bridge to symbolise the failure of the scheme as a whole. Gould claimed that the Government offered greater ongoing economic support to the soldier settlers than it had given to previous groups of Crown settlers, and argued that this support meant larger numbers of "soldiers survived on their farms than is generally recognised." 430

Popular support for the mass settlement of returned servicemen on the land was intense: newspaper journalists repeatedly declared that soldiers had a "moral claim" on the land as a reward for service, and that the scheme would benefit the country as a whole: military service was "a hard and effective training school from which a magnificent yeomanry will emerge". ${ }^{431}$ Reiterating this popular sentiment, Herdman told Parliament that it was the "duty of the State" to ensure a rapid resettlement of soldiers, and that this would be mutually beneficial for both the soldier and the State. ${ }^{432}$ Similarly, the Under-Secretary of Lands wrote in 1916 that many soldiers were now "enamoured with the open-air life that a military campaign entails", that it was the "duty of the State" to do all it reasonably could for them, and that it was "an advantage to the State" to settle them in the country rather than in towns. ${ }^{433}$ However, the Government had no intention of gifting the land. Administrators claimed that it was "unkind" to "pamper" returning soldiers, as charity would loosen their moral fibre and "transform gallant, efficient fellows into dependants." 434 Consequently, the Government loaned soldiers the funds to purchase farms in much the same way as they had assisted previous groups of Crown settlers under the successful and popular schemes set up by the Liberals of the 1890 s.

The Discharged Soldiers Settlement Act 1915 authorised the Governor to set aside Crown land for sale or lease specifically to honourably discharged soldiers, under the same terms as the Land for Settlements Act and Land Act. ${ }^{435}$ The Act also provided £50,000 for both administering the scheme, and for monetary assistance to soldier farmers in preparing and stocking their land (up to $£ 500$ per settler); it even gave the Minister of Lands the power to remit rent, but prohibited soldiers from reselling this land for ten years. ${ }^{436}$ The following

\footnotetext{
430 Gould, "Proof of Gratitude?" p.ii.

${ }^{431}$ Evening Post, 3 May 1916, p.6; Auckland Weekly News, 18 January 1917, p.47.

432 NZPD vol.181, 11 October 1917, p.44.

${ }^{433}$ AJHR 1916, C-9, p.1.

${ }^{434}$ AJHR 1918, H-19C, p.58-9.

435 Discharged Soldiers Settlement Act 1915, s3-4.

${ }^{436}$ Discharged Soldiers Settlement Act 1915, s6-8, s11.
} 
year an amendment opened the scheme up to New Zealanders who had served with other British forces, and increased the scheme's available capital to $£ 500,000 .{ }^{437}$

Speaking to a Royal Colonial Institute luncheon in London in October 1916, Massey stated that his Government had set apart 500,000 acres - "the best of the Crown land now remaining" - and had purchased another 100,000 acres of private land for the settlement of returning soldiers. At this point, Massey expected to place "a minimum of 5,000 soldiers" on farms; in fact, the eventual figure was just over twice this number. ${ }^{438}$ Despite RSA and Farmers' Union support for compulsory purchase of large estates for redistribution to returned servicemen - and a campaign for such purchases pushed by the Evening Post such an idea was contrary to Reform Party philosophy, and Massey dismissed existing compulsory purchase legislation as unworkable. ${ }^{439}$

At the beginning of 1916, the Prime Minister claimed that his Government had "permanently" set aside 100,000 acres (and "provisionally" another 400,000) exclusively for returning soldiers, predominantly "good land, in good localities, and easy of access." 440 Nevertheless, realising that the Government might not be able to offer sufficient Crown land to satisfy all prospective soldier farmers in a timely fashion, a 1917 amendment also provided financing to help soldiers purchase privately owned land, either by loaning the money directly to the purchasing soldier (section 2), or by having the Crown first purchase the land on their behalf (section 3). ${ }^{441}$ These multiple methods for providing land to soldier farmers have created much confusion for those assessing the scheme's success: ${ }^{442}$ Gould notes that figures for the number of soldier settlers cited by historians vary from 4,000 (which does not include the section 2 settlers) to over 20,000 (which includes both urban and rural settlers). ${ }^{443}$ As we shall see below, these conflicting figures have created problems

\footnotetext{
437 Discharged Soldiers Settlement Amendment Act 1916, s3, s6.

438 'The Empire and Enemy Trade', 27 October 1916: W.F. Massey, "The Call of Empire: Speeches and Interviews in Great Britain, 1916-7," (AT: Micro-MS-0843), p.44-5. The Under-Secretary of Lands that same year claimed that there were "in the Dominion a total of about 500,000 acres of land more or less suitable" but only 67,855 had been formally reserved for the soldiers: AJHR 1916, C-9, p.4. Gould has called Massey's claims in the above speech "creative disinformation": Gould, "Proof of Gratitude?" p.120.

${ }^{439}$ Evening Post, 19 February 1916, p.3; 3 May 1916, p.6; 16 May 1916, p.6; Gould, “Proof of Gratitude?” p.21, 124.

440 Dominion, 10 January 1916, p.4.

${ }^{441}$ Discharged Soldiers Settlement Amendment Act 1917, s2-3.

${ }^{442}$ Already in 1919 the Under-Secretary for Lands was commenting on this confusion: AJHR 1919, C-9, p.2.

${ }^{443}$ Gould, "Proof of Gratitude?" p.37-8.
} 
for assessing the failure rate of the soldier farmers: J.P. Condliffe, in the 1930s, simply stated that it was "impossible to estimate with any accuracy the total loss involved in the abandonment of holdings and also in the reduction of equities." 444

The scheme as a whole was directed by the Under-Secretary for Lands (head of the Department of Lands and Survey) and a central Land Purchase Board, while allocation of individual farms via local ballots was administered by eleven pre-existing regional Land Boards, with assistance from the Valuation Department and the Surveyor-General's Office. ${ }^{445}$ Additionally, each of the eleven districts possessed both a Crown Lands Ranger to oversee the new farmers, and, from 1919, a Supervisor of Soldier Settlements. ${ }^{446}$ After a slow start during the war years, the Land Boards organised thousands of purchases by soldier settlers each year from 1918 to 1921; by 1923, 21,584 returned soldiers had been settled under the legislation, approximately half on farms and half on urban and suburban properties, and the settlement was considered roughly complete; the Under-Secretary of Lands stated that a majority of the town settlers had found employment, often with Government assistance, and been able to meet their repayments. ${ }^{447}$

In contrast, and in spite of the extensive purchasing and supervisory mechanisms, administrators overseeing the soldier farmers began to observe problems within the first years, and the section 2 farms became particularly controversial for contributing to inflated land prices. The Under-Secretary remarked in 1922 that many had "suffered through inexperience", though he now believed that this experience had been gained through trial and error, and expected all those who showed "the necessary spirit of self-reliance" to succeed. ${ }^{448}$ Although Massey had initially envisioned settling men on land only after they had gained the necessary farming experience to make good, the large numbers seeking land without delay (more than double the 5,000 Massey originally envisaged), coupled with public pressure to reward men for service made this difficult; what training schemes were offered were haphazard and unpopular. ${ }^{449}$ Rather than strictly ensuring soldiers were settled on profitable land, James Allen told a representative from the RSA that the

\footnotetext{
${ }^{444}$ Condliffe, p.276.

${ }^{445}$ Gould, “Proof of Gratitude?” p.107-8.

${ }^{446}$ Gould, "Proof of Gratitude?" p.199.

${ }^{447}$ AJHR 1922, C-9, p.2; 1923, C-9, p.2; 1924, C-9, p.1; 1925, C-9, p.11.

${ }_{448}$ AJHR 1922, C-9, p.7; 1921, C-9, p.2.

${ }^{449}$ Gould, "Proof of Gratitude?" p.82-5.
} 
Government would help "purchase any land, good, bad, or indifferent, so long as it suited the soldier." 450 The RSA had urged the process of settlement be accelerated to prevent returned servicemen drifting about the country, wasting money. ${ }^{451}$

Beginning in the 1930s, historians have criticised the Government for "turning loose" approximately 22,000 "new purchasers" with more than $£ 20,000$ in "borrowed money", thus driving up land prices "already inflated" by the wartime commodity price boom. ${ }^{452}$ Keith Sinclair and Tom Brooking have both cited estimates that "half the rural land in New Zealand changed hands between 1916 [or 1915] and 1924", and that this speculation could "only be described as gambling", or even "an orgy of gambling on land values". ${ }^{453}$ The Government had little control over prices paid on the private market, even as they provided the financing: according to Condliffe, "little provision was made to control the advance in land values resulting from this increased demand." ${ }^{454}$ Inflated property prices meant settlers faced unrealistic rent or mortgage payments; the collapse in commodity prices in 1921, followed by a further downturn in 1926 and the onset of the Great Depression in 1929 , ensured that a great many of these men had insufficient capital to meet their obligations, leaving them, in the words of Bill Oliver, "bewildered, annoyed and suspicious." 455

In 1921, the Under-Secretary for Lands noted that the "unfortunate drop in the prices of wool and frozen meat" had hurt "many soldier settlers who were just beginning to make their farms pay." ${ }^{456}$ The Government responded with an Amendment Act that year, allowing the Minister of Lands to postpone mortgage repayments from struggling section 2 farmers. ${ }^{457} \mathrm{~A}$ year later, the situation had still not improved - a number of soldier settlers had walked off their farms, newspapers and farming organisations began to call for revaluations of mortgages and rents, and a general election was impending, so the Reform Government announced a series of local Inquiry Boards to look into these demands. ${ }^{458}$ The

\footnotetext{
${ }^{450}$ Dominion, 1 June 1917, p.6.

451 Gould, "Proof of Gratitude?” p.171.

452 Condliffe, p.276; W.P. Morrell, New Zealand (London: Ernest Benn, 1935), p.111; ; Sinclair, p.244.

453 Sinclair, p.244; Tom Brooking, p.232.

${ }^{454}$ Condliffe, p.276.

455 W.H. Oliver, The Story of New Zealand (London: Faber and Faber, 1960), p.173.

${ }^{456}$ AJHR 1921, C-9, p.2.

457 Discharged Soldiers Settlement Amendment Act 1921, s16.

${ }^{458}$ Gould, “Proof of Gratitude?" p.242-4.
} 
Department of Lands and Survey sent out questionnaires to 7,625 soldier settlers and received 4,322 replies; the Inquiry Boards then examined farms from which they'd received feedback, and the following year a report was tabled in parliament, containing the Inquiry Boards' recommendations, along with responses from the Land Boards and the UnderSecretary.

The Under-Secretary, J.B. Thompson, noted there was "no difference of opinion between the Land Boards and Inquiry Boards" that more assistance was necessary, but there was a great deal of dispute over the level of failure and the appropriate response: for example, while the North Auckland Inquiry Board recommended revaluation, the Land Board for the same area recommended "postponement of rent and interest"; the Wellington Inquiry Board also recommended revaluation, while the Hawkes Bay Inquiry Board recommended "remissions and postponements." Noting these conflicts, the Under-Secretary argued that relief needed to be "uniform throughout the Dominion", and that he must reject recommendations for "wholesale" remissions of rent and mortgages, in favour of "a rebate on the amount" by which farms were overvalued only. ${ }^{459}$

The various Inquiry Boards also differed widely on their attitudes towards why farms were failing. While the Auckland Board believed "stricter examination" should have been made of prospective farmers' qualifications, and the Malborough Board argued that farmers "would have done better with more initiative and more capital", the Nelson Board claimed that "it was no fault" of the settlers "that things have not turned out successfully", being placed in an "impossible" position owing to the low-quality of many farms and the markets' collapse. ${ }^{460}$ The Otago Board noted that, while all farmers had been hit by the fall in prices, soldier settlers were particularly hurt due to their lack of capital and the fact that they had not reaped the reward of the boom years. ${ }^{461}$ Various Boards also noted that there were not enough Rangers and Supervisors to effectively advise first-time farmers. ${ }^{462}$

Overall, Thompson concluded that the inspected farms had "not been generally satisfactory." He presumed that the 3,303 farmers who failed to respond "were satisfied

\footnotetext{
${ }^{459}$ AJHR 1923, C-9A, p.32, 34.

${ }^{460}$ AJHR 1923, C-9A, p.5, 13, 15, 17.

${ }^{461}$ AJHR 1923, C-9A, p.18-9.

${ }^{462}$ AJHR 1923, C-9A, p.7, 13.
} 
and well-placed"; though it is possible some of those non-responsive farmers may have already failed, one of the Inquiry Boards supported the Under-Secretary's assumption, stating that ninety-five per cent of non-responsive farmers were succeeding. ${ }^{463}$ Of the 4,322 farms inspected, the Inquiry Boards concluded that 50.6 per cent were successful, 30.7 per cent were temporarily unsuccessful (i.e. potentially successful with further assistance), and 18.7 per cent had permanently failed. ${ }^{464}$

The major problems were, as predicted, associated with the farms bought from private vendors under section 2 of the Act, but Thompson did not believe the inflated price paid for land alone gave "the true cause of unsuccessful operation", since the Government had received "very little income" in the form of mortgage and rent payments from these properties - if settlers were not actually paying the instalments, they could not be said to be crippled by their cost. ${ }^{465}$ Instead, he stated that "the great factors of unsuccessful operation" could "be attributed to the 'peak' prices of labour, stock, building, fencing and other materials." While he did believe revaluation was unavoidable, he preferred in most cases mere postponement of payments, as this would place "all settlers on the one footing." ${ }^{466}$ Furthermore, revaluing section 2 mortgages presented the problem that many of the section 2 farmers had taken out a second, private mortgage: Thompson claimed that his "Department's valuations of land" were "generally very sound and not inflated, but many of the settlers now in difficulties bought their land at high prices above the Department's valuation" and taken out second mortgages, often from the seller, to cover the balance. If only the initial Crown mortgage were reduced, the revaluation would benefit not the settler or the state, but the second mortgagee. ${ }^{467}$

In response to this report, the Government passed another Amendment Act, the main purpose of which was to set up a Discharged Soldiers Dominion Revaluation Board. ${ }^{468}$ The Amendment also contained a provision "for postponement or remission of arrears of rent or interest", in aid of those whose farms would not be revaluated. ${ }^{469}$ This Board generally

\footnotetext{
463 AJHR 1923, C-9A, p.33, 35.

${ }^{464}$ AJHR 1923, C-9A, p.22.

465 AJHR 1923, C-9A, p.35; AJHR 1923, C-9, p.5.

${ }^{466}$ AJHR 1923, C-9A, p.35.

${ }^{467}$ AJHR 1923, C-9A, p.33-4.

468 Discharged Soldiers Settlement Amendment Act 1923, s2.

${ }^{469}$ Discharged Soldiers Settlement Amendment Act 1923, s11.
} 
followed Thompson's advice in preferring to grant postponements of rent and mortgage payments. ${ }^{470}$ However, over the course of two years it dealt with 5,284 applications for revaluation, reducing the value of section 2 farms by a combined $£ 2.58$ million (from a total value of $£ 17.33$ million), negotiated to reduce the value of second mortgages by 75.4 per cent, and bought-out $£ 56,531$ of these private debts at a discount of 37.7 per cent. ${ }^{471}$

Following these extensive measures to aid soldier settlers, the Government was able to claim that the scheme was now a success, with the new Prime Minister, Joseph Ward, claiming in 1929 that the remaining soldier farmers were "satisfactorily established." ${ }^{472}$ But of course, that same year the Great Depression hit, and farmers suffered through another commodity market crash, leading to further failures; four years later, the Government refused calls for another round of revaluations. ${ }^{473}$

Attempting to evaluate exactly how many of the soldier farmers failed, either by forfeiting, surrendering, or simply walking off their properties, is made fraught by the complexities of the scheme, particularly the multiple different forms of tenure for which it provided. Gould devoted the penultimate chapter of his thesis, and the second half of a book chapter, to the goal of determining the exact rate of success and failure of these farms. ${ }^{474}$ While some historians have stated a failure rate of around thirty per cent by the end of the Great Depression, the problem with this figure is that by this time many farms had been successfully paid off, and these successes, being no longer included in the number of tenants, have been included among the numbers failed. ${ }^{475}$ Therefore, I must limit myself to addressing the figures relating to the first decade of the scheme.

Using figures from the Lands and Survey Department in both the Appendices to the Journals of the House of Representatives, and the National Archives, Gould calculates an annual failure rate (forfeitures and surrenders) between 1919 and 1924 of 1.64 per cent for nonsoldier Crown tenants and 2.66 per cent for soldier settlers, then suggests that the

\footnotetext{
470 Gould, “Proof of Gratitude?” p.255.

${ }^{471}$ AJHR 1925, C-9, p.4; 1927, C-9, p.3.

472 Gould, "Proof of Gratitude?" p.269.

473 Gould, "Proof of Gratitude?" p.274.

${ }^{474}$ Gould, "Proof of Gratitude?" p.283-304; Gould, "Soldier Settlement in New Zealand After World War I: A Reappraisal," p.123-7.

475 Boyack and Tolerton, p.247; Gould, "Soldier Settlement in New Zealand After World War I: A Reappraisal," p.124; "Proof of Gratitude?" p.291.
} 
"difference of 1.02 per cent is hardly significant," given their lack of capital and experience, and likely poor health. ${ }^{476}$ However, while the failure rate given for soldier settlers is indeed 1.02 basis points higher than that given for civilians, comparing these two failure rates actually gives a sixty per cent higher comparative failure rate for soldiers, which is not insignificant. However, I do not believe these figures give a sufficiently broad or accurate account of the failure rate in the early part of the scheme.

The most straightforward account of the success and failure of soldier farmers through the depression of the early 1920 s and the revaluations that followed, is a letter from the Prime Minister to the Premier of Victoria in 1925, advising the latter as to the success of the New Zealand scheme, and based on advice from the Under-Secretary of Lands. This letter cites a figure of 9,261 returned servicemen settled on 4,144, 852 acres by July 1924, with 5,215 settled on Crown lands and 4,406 settled on private lands with Government advances (the section 2 men). 520 farms had been forfeited or surrendered and a further 475 abandoned, a failure rate of ten per cent. From an initial capital outlay of $£ 13,896,663$, the Government had written off $£ 2,131,614$ in forfeited payments and revaluations, a loss of fifteen per cent. ${ }^{477}$ While these figures do not depict a catastrophic failure of the scheme, they do indicate that the Inquiry Boards and subsequent revaluation scheme were necessitated by an unacceptably high loss to both the state and returned servicemen.

Gould suggests that while "the soldiers for the most part remained on their properties, it was not on the terms that either they or the government had anticipated", and that the reason for the historiographical portrait of the scheme as a disaster owes much to the feeling of "guilt" towards these men. ${ }^{478}$ This understates the significance of the scheme's failure, and overstates the inaccuracy of the accepted account of the scheme as a disaster. However, where Gould has correctly shown the accepted account to be flawed is in his demonstration that soldier settlers were not abandoned: the Revaluation Board was just one part of an ongoing involvement of the state in the lives of the soldier settlers, an

\footnotetext{
${ }^{476}$ Gould, "Soldier Settlement in New Zealand After World War I: A Reappraisal," p.126. Using the same AJHR sources, I calculate a slightly different annual failure rate for civilian Crown settlers of 1.59 per cent: AJHR, C-1: 1919, p.43-4; 1920, p.34; 1921, p.4, 41; 1922, p.4, 39; 1923, p.40; 1924, p.5, 45.

477 Prime Minister of New Zealand to Premier of Victoria, 21 February 1925 (NA: Land Settlement (Development), Box: 2, Record: 26/1, Part:10, Item ID: R10639552).

478 Gould, "Soldier Settlement in New Zealand After World War I: A Reappraisal," p.128; "Proof of Gratitude?" p.305.
} 
involvement which would go on to influence an increased role for the state in the finances of all farmers. Although the Government refrained from carrying further revaluations of soldiers' farms during the Great Depression, the First Labour Government did introduce a general Mortgage Corporation in its first year in Government: this Corporation offered relief to settlers struggling to maintain their farms, and as Gould points out, owed much to the experience of the Discharged Soldiers Dominion Revaluation Board a decade earlier. ${ }^{479}$ Gould also points out that not all of the Government's interventions helped the soldier settlers: provisions to protect soldier farmers from civil action while on service were extended beyond the end of the war, and these protections could discourage organisations from doing business with men whom they could not take to court. ${ }^{480}$ Restrictions on soldier settlers selling stock, aimed to protect inexperienced farmers from being exploited, could both prevent them from making profitable deals, and discourage other parties from doing business with the soldier farmers. ${ }^{481}$

The State's role in the lives of soldier farmers was therefore decidedly mixed. The sheer number of men taking up properties, and a lack of initial oversight of sales, caused a spike in property prices which spelt disaster once commodity markets collapsed. In order not to abandon those who had fought for the Empire, the state, sometimes reluctantly, continued to offer financial aid throughout the 1920s, creating a precedent which would become permanent from 1935; but this involvement could have negative side effects. Ultimately, the problems associated with the scheme caused significant hardship for the soldier settlers, but also resulted in a greater involvement of the State in the lives of all New Zealand farmers.

So far, I have focused only on the predominantly Pakeha soldier settlers from New Zealand, but there are two groups of soldiers who settled in the Dominion in the 1920s who should be considered separately: Maori returned servicemen, and soldier migrants from Britain. British soldiers were not included under the provisions of the Discharged Soldiers Settlement Act, although we shall see in a moment that New Zealand participated in

\footnotetext{
${ }^{479}$ Gould, "Soldier Settlement in New Zealand After World War I: A Reappraisal," p.122-3; “Proof of Gratitude?" p.274-5; Barrie MacDonald and David Thomson, "Mortgage Relief, Farm Finance, and Rural Depression in New Zealand in the 1930s," New Zealand Journal of History 21, 2 (1987), p.242.

480 Gould, "Proof of Gratitude?" p.192-3.

${ }^{481}$ Gould, "Proof of Gratitude?" p.210, 212.
} 
schemes to settle them in the Dominions. Maori were technically eligible under the Act, though many historians have stated that they were not, in practice, included. ${ }^{482}$ Gould has corrected these claims, tracing sixty-one Maori returned servicemen who participated in the government's repatriations schemes; forty-one acquired farms. ${ }^{483}$ This number, from a total of around 1800 Maori returned servicemen, means that approximately two per cent of Maori soldiers participated in the land scheme, as opposed to ten per cent of Pakeha soldiers. ${ }^{484}$ Gould points out that simply including Maori under the scheme in the same way as Pakeha soldiers would have been "assimilationist":as Ngata stated, Maori soldiers wanted instead to have provision made to assist them in returning to, and successfully farming, their own lands. ${ }^{485}$ Government efforts to include Maori in farming assistance measures were regularly opposed by local Pakeha, who perceived Maori as already "landrich". 486 One block of land, Otamarakau in the Bay of Plenty, was set aside specifically for Maori soldiers, but following public pressure, was opened up to Pakeha as well. Ultimately, the few Maori soldiers who did participate in the scheme suffered similar failure rates to Pakeha, and the fact that so few succeeded perhaps explains why historians came to believe that nothing was attempted. ${ }^{487}$

\section{Post-War British Migration}

The Oversea Settlement Committee was established by the British Government in 1919 to co-ordinate assisted emigration to the Dominions, and operated a free-passage scheme for returned servicemen until 1922, when it was succeeded by the Empire Settlement Act. The Committee was the brainchild of the new Colonial Secretary, Lord Milner, and his Under-

\footnotetext{
482 Baker, p.221; Claudia Orange, The Treaty of Waitangi (Wellington: Allen \& Unwin, 1987), p.231; Michael King, "Between Two Worlds," in ," in W.H. Oliver and B.R. Williams eds., The Oxford History of New Zealand (Wellington: Oxford University Press, 1981), p.297; Phillipa Mein Smith, A Concise History of New Zealand (Cambridge: Cambridge University Press, 2005), p.147.

${ }^{483}$ Ashley Gould, "From Taiaha to Ko: Repatriation and Land Settlement for Maori Soldiers in New Zealand After the First World War," War and Society 28, 2 (2009), p.54; this figure of 61 soldiers is an increase on the thirty he had traced at the time of his thesis: Gould, "Proof of Gratitude?" p.311.

${ }^{484}$ Gould, "Proof of Gratitude?" p.328.

485 Gould, "From Taiaha to Ko," p.52-3; Gould, "Proof of Gratitude?" p.319, 327.

${ }^{486}$ Gould, Proof of Gratitude?" p.317; Gould, "From Taiaha to Ko," p.66-7.

${ }^{487}$ Gould, "From Taiaha to Ko," p.69-72, 78.
} 
Secretary at the Colonial Office, Leopold Amery. ${ }^{488}$ Amery argued that assisted migration from Britain to the Dominions would reduce unemployment at home and grow markets for British produce throughout the Empire. ${ }^{489}$ British migration had already shifted from the USA to the Dominions in the first decade of the twentieth century, without the aid of state assistance. ${ }^{490}$ There was a great deal of suspicion in the Dominions towards assisted migration, stemming from schemes in the nineteenth century which were remembered as "shovelling out paupers", criminals and other desirables to the colonies: Amery observed that his "first task" was to "get rid of the word 'emigration', its association of unemployment and expatriation, and to substitute 'migration' for the actual movement from one part of the empire to another". ${ }^{491}$ Amery also argued that ex-servicemen were a special case, being entitled to the "reward" of emigration. ${ }^{492}$ Milner's peers in Cabinet were also sceptical, believing that prosperity would soon return to Britain, and that the country would in fact face a shortage of labour; only when the opposite proved to be the case, and serious industrial unrest threatened to result from the number of returned servicemen unable to find work, did the government embrace Milner and Amery's scheme; the continuation of unemployment also prompted the government to extend the scheme into the Empire Settlement Act of $1922 .{ }^{493}$

The Dominions were given the responsibility for screening applicants before accepting them; only then would Britain pay their fares. A total of 86,000 ex-servicemen and their families were assisted between 1919 and 1923, far short of Amery's intention for fourhundred thousand (almost two-hundred-thousand applicants were declined); the cost to his government was just under two-and-a-half million pounds. ${ }^{494}$ Canada and Australia were

\footnotetext{
${ }^{488}$ Kent Fedorowich, Unfit for Heroes: Reconstruction and Soldier Settlement in the Empire Between the Wars (Manchester: Manchester University Press, 1995), p.37; Dane Kennedy, "Empire Migration in Post-War Reconstruction: The Role of the Oversea Settlement Committee, 1919-1920," Albion: A Quarterly Journal Concerned with British Studies 20, 3 (1988), p.404-6.

${ }^{489}$ Kennedy, p.406-7.

${ }^{490}$ Stephen Constantine, "Introduction: Empire Migration and Imperial Harmony," in Stephen Constantine ed. Emigrants and Empire: British Settlement in the Dominions Between the Wars (Manchester: Manchester University Press, 1990), p.2.

${ }^{491}$ Keith Williams, "'A Way Out Of Our Troubles': The Politics of Empire Settlement, 1900-1922," in Constantine ed., p.25-7; Eric Richards, Britannia's Children: Emigration from England, Scotland, Wales and Ireland since 1600 (London: Hambledon \& London, 2004), p.243.

492 Fedorowich, Unfit for Heroes, p.37-8.

${ }^{493}$ Kent Fedorowich, "The Assisted Emigration of British Ex-Servicemen to the Dominions, 1914-1922," in Constantine ed., p.55-6; Williams, p.37-42; Fedorowich, Unfit for Heroes, p.38-9.

${ }^{494}$ Fedorowich, Unfit for Heroes, p.41; Constantine, "Introduction," p.15; Richards, p.243; Kennedy, p.415.
} 
the most enthusiastic respondents to the scheme - though this did not mean that soldiers who settled there prospered - while South Africa was the least enthusiastic. 42 per cent of the migrants went to Australia, 32 to Canada, 16 to New Zealand and 7 to South Africa - in all, these assisted ex-servicemen constituted twelve per cent of the total number of British migrants during this period. ${ }^{495}$

Under both this scheme and the later Empire Settlement Act, 44,745 British migrants were assisted to New Zealand by $1936 .{ }^{496}$ New Zealand's government had in fact asked for the scheme during the war. ${ }^{497}$ Yet the "most patriotic and 'British' of the dominions" was reluctant to accept British soldiers onto its land, due to the simple fact that New Zealand did not have vast tracts of empty land, unlike Australia or Canada. ${ }^{498}$ Already in 1916, when the adventure novelist Sir Henry Rider Haggard visited the Dominions to look into the possibility of settling British troops on Dominion farms, one New Zealand parliamentarian stated that while we would "not shut our country against our kith and kin in the Old Country," we had first "a right and a duty towards those brave New Zealanders" who had "gone forth to do battle in defence of this Dominion and the Empire." ${ }^{499}$ Massey was more positive about the visit. ${ }^{500}$ Concerned that there would be an "exodus" of men after the war, Haggard was determined to keep these men within the Empire, and travelled through the Dominions to discuss the matter with their governments. 501

When the time came to accept assisted British ex-servicemen after the war, the Massey government stressed the need to first settle New Zealand's own men; that this task was never adequately completed ensured a lack of enthusiasm for the Oversea Settlement Scheme, worsened by a serious housing shortage, especially in Wellington. The Dominion insisted on taking only those men whose employment and accommodation could be guaranteed. ${ }^{502}$ Labour leaders complained that the scheme was "designed more to serve

\footnotetext{
495 Richards, p. 243.

${ }^{496}$ Constantine, "Introduction," p.16.

${ }^{497}$ Fedorowich, Unfit for Heroes, p.31.

${ }^{498}$ Fedorowich, "The Assisted Emigration of British Ex-Servicemen to the Dominions, 1914-1922," p.58.

${ }^{499}$ MHR Jennings: NZPD 1916, vol.175, p.96.

${ }^{500}$ NZPD 1915, vol.174, p.356.

${ }^{501}$ Evening Post, 13 January 1916, p.7; Fedorowich, Unfit for Heroes, p.53-9.

502 NZPD 1919, vol,185, p.312; NZPD 1920, vol.186, p.687-8; NZPD 1920, vol.189, p.681; Fedorowich, "The Assisted Emigration of British Ex-Servicemen to the Dominions, 1914-1922," p.58; Fedorowich, Unfit for Heroes, p.179.
} 
Great Britain than New Zealand." 503 Nevertheless, by 1923 New Zealand had received 13,349 British soldiers and family members. ${ }^{504}$ In spite of Haggard's dreams, only one of these emigrants is recorded as having become a farmer. ${ }^{505}$ Farm labourers, however, were in demand. 506

The settlement of New Zealand soldiers on farms, and of British soldiers in New Zealand, was promoted as a reward for service rather than an act of charity. This notion of a reward for service would increasingly come to dominate welfare discourse as a whole.

\section{$\underline{\text { Welfare }}$}

By August 1914, New Zealand's state welfare system consisted of hospitals administered by local boards; subsidies to voluntary charity organisations; non-contributory pensions to two groups considered the most deserving - the elderly and widows with children - who could prove their poverty and meet certain "moral" requirements; and several contributory pension and insurance schemes, including unemployment and accident insurance.

A Destitute Persons Ordinance in 1846 established the legal responsibility of families to provide for impoverished European relatives, a principle reconfirmed by the colonial government's Destitute Persons Act 1877.Nevertheless, with a population heavily weighted towards single unattached men, family ties were never going to suffice, and groups of volunteers founded various local charitable organisations over the next four decades. ${ }^{507}$ The Stout-Vogel Government, attempting "to marry local responsibility with central funding and oversight", passed a Hospitals and Charitable Institutions Act in 1885, which consolidated these groups under the oversight of the state via local Hospital and Charitable Aid Boards. The Act also promised to subsidise private charity on a pound-for-pound basis. ${ }^{508}$ To receive

\footnotetext{
${ }^{503}$ Stephen Constantine, "Immigration and the Making of New Zealand, 1918-1939," in Constantine ed., p.127. ${ }^{504}$ Fedorowich, "The Assisted Emigration of British Ex-Servicemen to the Dominions, 1914-1922," p.59; Fedorowich, Unfit for Heroes, p.180.

${ }^{505}$ Fedorowich, Unfit for Heroes, p.181.

${ }^{506}$ Constantine, "Immigration and the Making of New Zealand, 1918-1939," p.137.

507 Margaret Tennant, Paupers and Providers: Charitable Aid in New Zealand (Wellington: Allen and Unwin, 1989), p.13; Margaret McClure, A Civilised Community: A History of Social Security in New Zealand 1898-1998 (Auckland: Auckland University Press, 1998), p.12.

${ }^{508}$ Rising to $24 \mathrm{~s}$ to the pound in an amendment the following year: Tennant, Paupers and Providers, p.27-32, 36.
} 
this aid, recipients who were not ill enough to land in hospital had to prove both their poverty and moral worthiness to the Boards' inspectors, who all too frequently demeaned recipients. ${ }^{509}$

This demeaning attitude was encouraged by the chief Inspector, Duncan MacGregor, who argued that supplying charity created its demand: "outdoor relief is as catching as small-pox, and just as deadly." While supportive of private charities, MacGregor accused the Boards of "subsidising the survival of the unfit" in perpetrating "vicarious" state-directed charity. He believed the state's welfare system should be a harsh measure of last-resort, and advocated institutionalising "able-bodied loafers" who would be separated according to their sex. ${ }^{510} \mathrm{At}$ the same time he railed against the "callousness" of families seeking to "get rid of aged relatives" by condemning them to lunatic asylums. ${ }^{511}$

In contrast to their Inspector, Richard Seddon's government considered the work of the Charitable Aid Boards insufficient to meet the needs of the impoverished elderly, and accepted a role for the state in filling this gap. Seddon introduced a means-tested Old-age Pensions Act to much fanfare in 1898: his pension initially offered a maximum $£ 18$ per year to those over European and Maori (but not Asian) men and women over 65 who met residence, income, property, and morality requirements. ${ }^{512}$ While this statute demonstrated a clear rejection of MacGregor's stance against outdoor-relief, the Liberals shared his distinction between the deserving and undeserving: pension applicants had to appear in front of a Stipendiary Magistrate who would examine their moral character before an open court, and could not approve the pension without witnesses to testify to their character, with a particular emphasis upon sobriety. ${ }^{513}$ Some elderly New Zealanders said they would refuse to apply for a pension rather than submit to this "indignity", and some magistrates agreed that such public inquisitions should be abandoned. ${ }^{514}$ In 1911 the Liberal government introduced a separate Military Pension for elderly men who had fought in the

\footnotetext{
${ }^{509}$ McClure, p.13-4.

${ }^{510}$ AJHR 1896, H-22, p.1; 1897, H-22, p.1-2; 1898, H-22, p.4-5; Tristan Egarr, “Am I My Brother's Keeper?” (BA Hons Dissertation, University of Otago, 2006), p.48, 56.

${ }^{511}$ AJHR 1898, H-7, p.4-5; Egarr, “Am I My Brother's Keeper?” p.63-4.

512 McClure, p.17-21; Gaynor Whyte, "Beyond the Statute: Administration of Old-age Pensions to 1938," in Bronwyn Dalley and Margaret Tennant ed., Past Judgement: Social Policy in New Zealand History (Dunedin: University of Otago Press, 2004), p.126-7.

513 Old-age Pensions Act 1898, s18, s20; McClure, p.21-2.

${ }^{514}$ Whyte, p.127.
} 
New Zealand Wars of the previous century (or their widows), which was subsequently amended the following year by the Reform government to allow for a lesser standard of sobriety, and again in 1913 to remove income test. ${ }^{515}$

Reservations about the moral standard and the way income and morality were investigated were not shared by James Eman Smith, the Registrar in charge of pensions from 1902 to 1908. Smith introduced new measures for investigating claims, and wrote that these measures were "justified" by a subsequent fall in the number of claims approved - from 1,694 in 1902 to 1,063 two years later - besides the number of previously-approved pensioners whom his deputies removed from the rolls. ${ }^{516}$ Nevertheless, Gaynor Whyte has argued that "the complexity involved in working with a discretionary system could both advantage and disadvantage clients", as many registrars and magistrates took an approach the opposite of Smith's. Maori, however, were overwhelmingly disadvantaged by this discretion: from 1904, the Pensions Department had an unofficial policy of awarding Maori only two-thirds of the maximum rate - a policy officialised in 1925 by department head George Fache. Commissioner of Pensions from 1912 to 1929, Fache was the key figure in pensions during the War, and took a markedly hard personal line on Maori pension claims. ${ }^{517}$

The Reform Government's consolidation of the Pension Act and its amendments in 1913 dropped the requirement for hearings to be held in open court, but retained the demand for witnesses to testify to the claimants "good moral character", their "sober and reputable life". ${ }^{518}$ During the war period, Old-age Pensions were available to men from the age of 65 and women from the age of 60 (or five years earlier if the pensioner had two dependent children under 14), who had resided in New Zealand for 25 years, and who had an annual income under $£ 60$ and property valued at under $£ 260$. The maximum pension was $£ 26$ per year, with progressive reductions for those earning more than $£ 34$ or who owned property. ${ }^{519}$ Military Pensioners were entitled to a $£ 36$ pension, which was neither means-

\footnotetext{
515 Military Pensions Act 1911; Military Pensions Act 1912, s6; Pensions Act 1913 s23-26.

${ }^{516}$ NZ Gazette 1903, no.12, p.505-14; AJHR 1903, H-18, p.1.

${ }^{517}$ Whyte, p.132-4.

518 Pensions Act 1913, s8, s32, s33.

519 Pensions Act 1913, s9.
} 
tested nor reduced according to income and property. ${ }^{520}$ As Justin Strang has pointed out, this was not primarily a pension to alleviate poverty, but one to compensate for previous state service. ${ }^{521}$

The other means-tested public pension introduced prior to the war was a Widows Pension, brought in by Ward's Liberal government in 1911. Ward offered widows with legitimate children under $14 \mathrm{f6}$ per year plus another $£ 6$ per child, up to a maximum of $£ 30$; in 1914 Massey's government removed the $f 30$-limit to cater to larger families. As with the old-age pensions, widows' pension payments were adjusted downwards according to the recipient's income (on a $f$-for- $f$ basis on income over $f 100$ ) and property, and would only be awarded if a magistrate was satisfied by her "sober habits" and moral character".522 This pension succeeded a number compensation measures stemming from Britain's Fatal Accidents Act 1846, which made employers potentially liable for a family's welfare if the earnings of their breadwinner were affected by a workplace accident. New Zealand's Workers' Compensation for Accidents Act 1900 strengthened and widened the scope of this liability, though payments were limited to three years. Public demand for wider protection for families who lost their breadwinner, and employer opposition for financing this protection, compelled Ward to introduce the pension for widows with young children. ${ }^{523}$

The greatest increase to old-age and widows pensions came with the cost-of-living allowances introduced by Ward in the Finance Act of 1917. Liberal MHRs both in opposition and during the coalition period pressed for measures to address war-related inflation. All civil pensioners received a cost-of-living allowance in addition to their regular pension payments. This allowance was most significant for widows, who received a $f 6$-per-child annual allowance in addition to their $f 6$-per-child pension. By the end of the financial year in 1920, after the Finance Act 1919 had permanently incorporated these allowances into the regular pension payments, the state's total gross annual payments to widow pensioners had risen from $£ 38,016$ in the year ending 31 March 1917, to $£ 136,815$ - or from $6.6 \%$ of all civil pension payments, to $14.7 \%$.

\footnotetext{
520 Pensions Act 1913, s25.

521 Justin Strang, “Welfare in Transition: Reform's Income Support Policy, 1912-1928," p.74.

522 Pensions Act 1913, s18-19.

${ }^{523}$ Melanie Nolan, Breadwinning: New Zealand Women and the State (Christchurch: Canterbury University Press, 2000), p.74-83.
} 
As Welfare Table 2 demonstrates, the 1917 increase merely allowed old-age pensions to keep pace with inflation, whereas for widows the increase of 1917, plus and another in 1919 - when old-age pensions remained steady - doubled the real purchasing power of their pensions. This contrast demonstrates wartime pension policy moving away from a focus on the elderly, to an emphasis upon children: welfare as a means of building for the future replacing welfare as a reward for past service. This change supports Melanie Nolan's argument that the state's welfare system "enhanced the role of male breadwinners in society" and "encouraged women' domesticity" while discouraging women from work. ${ }^{524}$ This trend towards welfare for children also drove the expanding public health system of the time, with the establishment of a school medical service in 1912 and children's health camps in $1919 . .^{525}$

Against this trend of welfare for the needs of the future rather than service in the past is the increased emphasis on rewarding military service, which became the most significantly funded part of the pension system. Reform's War Pensions Act passed into law on the day the National Government was announced. It provided pension payments for disabled returned soldiers or the widows and children of those killed in the service, payments significantly higher than those offered to old-age pensioners, New Zealand War veterans or civil widows. While there was no standard means-test, as in the case of civil pensions, a War Pensions Board set the level of each pension on a case-by-case basis - however, maximum rates were set according to the soldier's rank. ${ }^{526}$ For example, the family of a deceased Private could receive a maximum of $£ 3$ per week, while the family of a high-ranking NonCommissioned Officer could receive up to $f 39 \mathrm{~s}$, and of the highest-ranking Commissioned Officer up to $f 59 \mathrm{~s} .{ }^{527}$ Pension rates were amended upwards in both of the following years. As Welfare Table 2 shows, average payments to War Pensioners remained higher than to any other group of pensioners until 1920. Furthermore, Welfare Table 1 shows that by 1919, War Pensioners outnumbered all other pensioners combined. Payments to those affected by the war thus drove the massive increase in government spending on welfare: total

\footnotetext{
524 Nolan, p.71.

525 Margaret Tennant, The Fabric of Welfare: Voluntary Organisations, Government and Welfare in New Zealand, 1840-2005 (Wellington: Bridget Williams Books, 2007), p.71.

${ }^{526}$ War Pensions Act 1914 s4-5.

${ }^{527}$ War Pensions Act 1914, First Schedule.
} 
government spending on pensions in 1920 was more than five times the amount spent in 1914, and more than half of this went towards War Pensioners.

Running parallel to this rapidly expanding pension system was another state welfare system via contributory insurance policies. The Liberal Government established a number of contributory superannuation funds for state employees - for Police in 1899 , railway workers in 1902, teachers in 1905, and for the public service as a whole in $1908 .{ }^{528}$ The state also operated a Government Life Insurance Office from 1869, which was complemented by an Accident Insurance division in 1901, and a separate State Fire Insurance Office in 1901. Also operating in New Zealand were various British friendly societies, private organisations who offered insurance against loss of income due to ill-health. These societies were monitored by a Friendly Societies Department, but in 1906 rejected Seddon's offer of state subsidies, not wanting interference with their management. ${ }^{529}$ Four years later, Ward established government-backed alternative, the National Provident Fund, which offered both insurance for loss of income due to ill-health, much like the Friendly Societies, as well as superannuation insurance; this scheme was only available to those earning an average of less than $£ 200$ per year, and could return deposits to those leaving the scheme. ${ }^{530}$ The scheme was intended to support the unemployed while still encouraging "self-reliance and thrift". 531

Unlike the Accident and Fire insurance offices, which the government had set up to compete directly with private insurers in order to reduce premiums, the National Provident Fund was intended to capture those on low incomes who could not afford to join friendly societies, but most needed to do so. ${ }^{532}$ However, the requirement for regular contributions still exceeded the abilities of many in poverty. Nevertheless, the Fund was successful, and diverted business away from friendly societies, provoking several Members of Parliament to complain of "unfair competition", so that in 1914 Reform amended it, to enable local government bodies to join, to allow those over 40 years of age to join, and to make provision for state assistance to the now-struggling friendly societies, whose hostility

\footnotetext{
528 Nolan, p.69-70; for details of the Police Provident Fund, see Evening Post, 4 November 1899, p.2.

529 Strang, p.147.

530 NZPD 1910, vol.152, p.275, 379.

${ }^{531}$ NZPD 1910, vol.152, p.383, 572.

532 NZPD 1911, vol.156, p.84.
} 
towards state intervention had now substantially lessened. ${ }^{533}$ This assistance to friendly societies was substantially increased in $1916 .{ }^{534}$

Whereas the Old-age and Widows Pensions were world-firsts, and thus not strongly indebted to British precedent, the NPF was explicitly influenced by German precedent; Members of Parliament continued to cite the German example as one to be emulated, even after hostilities commenced. 535

A further significant aspect of welfare policy during the war was its impact upon private charitable organisations. Margaret Tennant has documented how the war gave a massive boost to fundraising efforts with the formation of patriotic societies - at least 529 by 1918. However, these societies also diverting funds away from other causes, and some never regained their pre-war profile. Meanwhile, the government was forced to intervene in overseeing private fundraising efforts for war purposes, due to concerns over their management. ${ }^{536}$

The most extensive study of the welfare system during the war period, Justin Strang's MA Thesis "Welfare in Transition: Reform's Income Support Policy 1912-1928", makes three arguments. First, that contrary to the arguments of previous historians, the growth of the welfare system did not "stagnate" in this period. ${ }^{537}$ Second, that Reform's welfare policies were essentially the same as those of the Liberals. ${ }^{538}$ Third, that this shared policy centred around the idea of pension and insurance payments as compensation for previous service or catastrophic loss, rather than as income support. ${ }^{539}$

The first of these arguments is confirmed by the growth shown in Welfare Table 1 . The second, however, is fatally flawed due to Strang's failure to consider the policies of the National Government of $1915-19$ as coalition policies, rather than as Reform government policies. This is particularly significant as the finance portfolio was held by Liberal leader Joseph Ward, while Liberal Josiah Hanan was Minister in charge of the Friendly Societies

\footnotetext{
533 NZPD 1914, vol.169, p.413, 646-7; Strang, p.155.

534 Strang, p159-60.

535 NZPD 1910, vol.153, p. 282, 510, 515-6, 536, 539.

536 Tennant, The Fabric of Welfare, p.83-7; Margaret Tennant, "Mixed Economy or Moving Frontier? Welfare, the Voluntary Sector and Government," in Dalley and Tennant ed., Past Judgement, p.48-9.

537 Strang, p.ii, 139, 218.

538 Strang, p.ii, p.226-8.

${ }^{539}$ Strang, p.ii, 219-23.
} 
Department. Strang quotes a speech from Hanan as stating the objectives of the "Reform Government" - yet Hanan was perhaps the most liberal of the Liberal cabinet ministers. ${ }^{540}$ Whereas the previous, Reform Minister for Friendly Societies had argued that the state pension legislation "places a penalty upon thrift and rewards the thriftless", and that it was "not the function of the state to interfere with" the friendly societies, Hanan argued for the "duty" and "necessity of active constructive interference by the State". ${ }^{541}$ Furthermore, Strang describes the Miner's Pthisis Pension introduced by the National Government in 1915 as a reform policy. In fact, Ward's government had introduced a relief fund for injured miners or their widows and orphans in $1910 .{ }^{542}$ The Reform Government then made no moves to do more for their welfare until Ward came back into the government.

The only pensions introduced by Reform prior to the National coalition were the substantially amended Military Pensions and the new War Pensions. Both compensated soldiers and soldiers' dependants for past service - and, crucially, unlike the Liberal pensions, neither of these pensions were means-tested. Strang's third argument, that pensions were awarded as compensation rather than as a means of alleviating poverty, is thus on solid ground for Reform; but the Liberals' calls - while in opposition during the first year of war, and again from the backbenches while in coalition - for more to be done to alleviate the rising cost-of-living, fed into Ward's introduction of cost-of-living allowances in 1917. Both parties shared a policy of only awarding pensions to those who "deserved" to be compensated, but Liberal policy tied this compensation to economic need.

\footnotetext{
540 Strang, p.158.

541 NZPD 1914, vol.169, p.643; Dominion, 14 April 1916, p.7.

542 McClure, p.34.
} 
Welfare Table 1: New Zealand Public Pensions

\begin{tabular}{|c|c|c|c|}
\hline Year & & No. of pensioners & Total paid to pensioners ( $\mathrm{f}$ gross) \\
\hline 1911 & & 16,020 & 383,393 \\
\hline 1912 & & 17,437 & 408,219 \\
\hline 1913 & & 18,390 & 441,556 \\
\hline 1914 & & 20,830 & 473,300 \\
\hline 1915 & & 22,528 & 540,049 \\
\hline 1916 & - Total & 24,328 & 579,388 \\
\hline & - Non-War & 23,137 & 565,478 \\
\hline & - War & 1,191 & 13,910 \\
\hline 1917 & - Total & 28,360 & 752,375 \\
\hline & - Non-War & 23,191 & 571,986 \\
\hline & - War & 5,169 & 180,389 \\
\hline 1918 & - Total & 38,072 & $1,280,583$ \\
\hline & - Non-War & 23,575 & 765,138 \\
\hline & - War & 14,497 & 515,445 \\
\hline 1919 & - Total & 51,790 & $2,087,355$ \\
\hline & - Non-War & 24,363 & 887,600 \\
\hline & - War & 27,427 & 1,199,755 \\
\hline 1920 & - Total & 59,362 & $2,743,939$ \\
\hline & - Non-War & 24,791 & 931,520 \\
\hline & - War & 34,571 & $1,812,419$ \\
\hline
\end{tabular}




\section{Welfare Table 2}

Average Pension Payments, year-ending 31 March (including Cost of Living bonus from 1918)

$\begin{array}{llllll} & 1916 & 1917 & 1918 & 1919 & 1920 \\ \text { Old-Age } & £ 24 & £ 24 & £ 37 & £ 36 & £ 36 \\ \text { Widow } & £ 19 & £ 19 & £ 33 & £ 35 & £ 54 \\ \text { Military } & £ 36 & £ 36 & £ 46 & £ 45 & £ 46 \\ \text { Miner } & £ 45 & £ 41 & £ 50 & £ 52 & £ 56 \\ \text { War } & £ 46 & £ 52 & £ 62 & £ 59 & £ 54\end{array}$

Average Pension Payments, adjusted for inflation

$\begin{array}{llllll} & 1916 & 1917 & 1918 & 1919 & 1920 \\ \text { CPI } & 1000 & 1082 & 1171 & 1257 & 1405 \\ \text { Old-Age } & £ 24 & £ 224 \mathrm{~s} & £ 3112 \mathrm{~s} & £ 2813 \mathrm{~s} & £ 2512 \mathrm{~s} \\ \text { Widow } & £ 19 & £ 1711 \mathrm{~s} & £ 284 \mathrm{~s} & £ 2717 \mathrm{~s} & £ 389 \mathrm{~s} \\ \text { Military } & £ 36 & £ 335 \mathrm{~s} & £ 396 \mathrm{~s} & £ 3516 \mathrm{~s} & £ 3215 \mathrm{~s} \\ \text { Miner } & £ 45 & £ 3718 \mathrm{~s} & £ 4214 \mathrm{~s} & £ 417 \mathrm{~s} & £ 3917 \mathrm{~s} \\ \text { War } & £ 46 & £ 481 \mathrm{~s} & £ 5219 \mathrm{~s} & £ 4619 \mathrm{~s} & £ 389 \mathrm{~s}\end{array}$




\section{Conclusion}

The public demand to reward those who served had a significant influence on New Zealand's welfare policy. War pensions, like the Discharged Soldiers' Settlement Scheme, extended the state's assistance to soldiers well after the end of the war, and fed into subsequent expansions of state economic intervention. Similarly, the Imperial Commandeer of export produce fed into the establishment of producer boards for export control; and the wartime establishment of income tax as a major feature of government revenue gathering would only gain momentum. While the establishment of export boards was championed by Massey and Reform members of cabinet, the expansion of welfare provisions was driven by Ward and the Liberals. The economic interventions of the First World War government have a mixed record: the soldier settlement scheme and price controls are largely and (mostly) accurately regarded as unsuccessful, while the expansion of welfare provision, income tax gathering and producer boards became key features of subsequent economic policy, as they were received by both voters and administrators as successful measures for ensuring economic stability and a good standard of living. Consequently, the effects of the economic policies established during the war remain with us today. These effects saw a significant expansion in the size of the Dominion government, in the government's economic reach, allowing for a greater degree of independence - yet at the same time, the key role of the Imperial commandeer in growing the state's revenue gathering and economic intervention also tied this state closer to Britain, increasing dependence on British markets and reliance on the cooperation of the British government to ensure continued prosperity.

What I have referred to as the military-agrarian complex - the fact that ongoing troop supplies to Britain relied upon funds coming in from the export commandeer, the mutually beneficial relationship between the war effort and pastoral exports - provided the engine driving both an increase in the state's economic size and reach (with the commandeer and the cost of the war necessitating greater state involvement in the economy), and a tightening of links to Britain, as New Zealand relied more than ever on the British market to shore up economic prosperity. 


\section{Policing and Punishment in Wartime}

Following the end of major interracial military conflict, the New Zealanders of the latenineteenth century became a relatively settled, harmonious community. Crime rates fell significantly, and in the words of our official police histories, policing practices moved "inexorably" away from the use of military force, towards "milder" policing by community consensus; a "long-term shift [...] from order imposition to order maintenance" - from reactive to preventive policing - characterised the overall trend from the 1860 s to the 1820 s. ${ }^{543}$ However, crime rose during the late 1890 s and the era of strike-free industrial relations died ended in 1906, coinciding with fluctuating economic conditions and the breakup of the liberal political consensus. Ward's Liberal Government implemented a compulsory military training scheme in 1909; this required the policing and imprisonment of conscientious objectors, and the Government used violent force to crush trade unions from 1912. Graeme Dunstall described the New Zealand police at the end of the 1910s as "in essence a social fire-brigade service"; Richard Hill acknowledged that the industrial conflict of 1912-3 and military adventure which dominated the rest of the decade saw "tactical reversions to older, more coercive" policing, but characterised this reversion as an interruption of the predominantly settling social trend. ${ }^{544}$

In this chapter, I argue that the First World War was marked by a substantial increase in the power of the state's surveillance and disciplinary powers, and by tightening interaction between the administration of civil and military justice. This extension was driven by the motivation of legislators and enforcers to ensure loyalty to the British war effort: the Dominion state tightened its grip on New Zealanders to service the British Crown. Yet the increasing presence and severity of wartime law-enforcement did not mark a break from a narrative of demilitarisation or increasing harmony; rather, they furthered trends in place at the outbreak of war, trends which in many ways continued to increase once war came to an end. The militarisation of civilian justice, increased powers of surveillance and control, and

\footnotetext{
${ }^{543}$ Richard S. Hill, The Colonial Frontier Tamed: New Zealand Policing in Transition, 1867-1886 (Wellington: GP Books, 1989), p.354-5; Graeme Dunstall, A Policeman's Paradise? Policing a Stable Society, 1918-1945 (Palmerston North: Dunmore Press, 1999), p.2.

544 Dunstall, A Policeman's Paradise?, p.22; Richard S. Hill, The Iron Hand in the Velvet Glove: The Modernisation of Policing in New Zealand, 1886-1917 (Palmerston North: Dunmore Press, 1995), p.424.
} 
the erosion of civil liberties need to be understood not just as wartime emergency measures, but as reflecting the pre-existing beliefs of particular administrators, as well as responding to public demand.

\section{"I am the civil service": Solicitor-General Salmond's clash with Chief Justice Stout over the power of the Executive}

For the decade of the Great War, New Zealand possessed a Chief Justice who saw the rule of law as a check on the powers of the state, and a Solicitor General who saw the law as a tool of the state. These two clashed on this issue in two important cases: In 1912, they lined up over the issue of whether native land title could be enforced against the state - Stout, arguing that it could, prevailed; in 1917, during the darkest days of the war, Stout's insistence on the rule of no taxation without representation was countered by Salmond's appeal to the need for tyrannical powers during a time of crisis - in this case, the wartime emergency ensured Salmond's view came to prevail, and continue once war was over. Salmond's advocacy also weakened the law of evidence with little outcry.

To understand this clash over the power of the state, it is useful to compare the situation in New Zealand during the First World War with that in the United States in the era directly following the War of Independence. During the first three decades in the life of the American Republic, Thomas Jefferson and Alexander Hamilton fought a political duel for the personality of their nation. The idealistic Jefferson took his constitution's promise of liberty as absolute, and refused to allow America to develop a standing army. Hamilton, the realist, understood that external threats and internal disagreements over tax meant this dream endangered his nation's viability. Initially, Congress sided with Jefferson, refusing to countenance a standing military force significant enough to ever challenge civil leadership. But war with France erupted in 1798-9 and dragged these civilian leaders into accepting Hamilton's demand for a stronger central state with powers of physical coercion. Alien and Sedition Acts gave the state remarkably arbitrary powers of arrest, and in 1802 Jefferson himself established the military academy at West Point. ${ }^{545}$

${ }^{545}$ Simon Schama, The American Future: A History (London: The Bodley Head, 2008), p.41-54. 
New Zealand underwent its own version of the Jefferson-Hamilton debate during the 1910s, with Chief Justice Robert Stout standing in for Jefferson, and Solicitor General John Salmond playing the part of Hamilton. Where the Chief Justice argued the executive was bound by the letter of the law, the Solicitor General regarded the law as a tool of the sovereign, which could be disregarded in a time of crisis.

Sir Robert Stout was appointed Chief Justice of the New Zealand Supreme Court in1899, following a patchy parliamentary career characterised by spells as Prime Minister and Attorney General, and periods of electoral failure in which he returned to private legal practice. In 1893 he was widely regarded as next-in-line to the Liberal Government leadership, but being out of Parliament when Premiere Ballance died, he lost out to the more populist Seddon, who eventually ended their rivalry by appointing Stout to chair the Supreme Court. ${ }^{546}$

Stout began his legal career holding views in line with classical liberalism: his biographers have described Stout's liberalism as "radical individualism" - but as the colony developed and the role of the state increased, so too did Stout's liberalism alter, as he came to accept that the state had a role to help those who could not help themselves. Nevertheless, he stated that any state intervention must be of "primary social importance" and must not "diminish self-reliance". 547 Stout considered education to be the most important and beneficial of these necessary interventions, but remained sceptical of many other innovative legislations which increased the role of government in the lives of the people. ${ }^{548}$ As this scepticism was out of touch with the strong-state form of government practised in New Zealand, Stout often found himself in the minority opinion when judgements were passed by the Supreme Court, and appeals against his judgments had a high rate of success - a fact attributed to his "liberalism and reforming zeal." 549

John Salmond spent much of his legal career, in particular as Solicitor General, advocating the opposite position: that the central executive was essentially free to overrule and

\footnotetext{
546 David Hamer, "Stout, Robert", in Dictionary of New Zealand Biography, Te Ara - the Encyclopedia of New Zealand, updated 30-Oct-2012, URL: http://www.TeAra.govt.nz/en/biographies/2s48/stout-robert

547 Waldo Hilary Dunn and Ivor L.M. Richardson, Sir Robert Stout: A Biography (Wellington: AH and AW Reed, 1961), p.145-7.

548 Dunn and Richardson, p.120, 180.

${ }^{549}$ I.L.M. Richardson, "Sir Robert Stout," in Robin Cooke Q.C. ed., Portrait of a Profession: The Centennial Book of the New Zealand Law Society (Wellington: A. H. \& A. W. Reed, 1969), p.45; Dunn and Richardson, p.164-9.
} 
intervene when circumstances made state intervention advantageous. While practising as a country lawyer in Temuka during the 1890s, Salmond published a textbook on jurisprudence, in which he argued that the English Parliament was - and, indeed, ought to be - possessed of "infinite" sovereignty, unlimited by the laws it passed; and that the "English constitution" recognised "a sovereign executive, no less than a sovereign legislature" - in fact, Salmond went so far as to argue that the "executive power of the Crown" was "sovereign" over and above the power of the legislature. ${ }^{550}$ Although a subject might "claim rights against the state", such rights would be neither enforceable nor "legal". ${ }^{551}$ Furthermore, during "times of civil disturbance", the executive might even legally "put to silence" laws established by parliament: "extrajudicial force" might "lawfully supersede the ordinary process and course of law" when such force was "needed for the protection of the state and the public order against illegal violence". 552

The Dominion of New Zealand, being a "dependent state", possessed "no international personality" and was therefore not illimitable in its sovereignty in the way the British State. ${ }^{553}$ Nevertheless, in his capacity as a civil servant of the Dominion, Salmond would draw on the strong-state theories laid out in his Jurisprudence to argue against the courts of New Zealand setting limits on the executive. Such theories were reflected in his personality: according to Hubert Ostler, Salmond's subordinate at the Crown Law Office, the SolicitorGeneral was "an exacting chief, slow to praise and prompt to blame" who could "not brook opposition" and "treated his law officers as schoolboys rather than junior colleagues." 554 When Salmond appointed Ostler, and the latter confessed his concern at losing the freedoms of a lawyer to become a civil servant under the hand of a Minister, Salmond

\footnotetext{
550 John Salmond, Jurisprudence, or the Theory of the Law $2^{\text {nd }}$ edn. (London: Stevens and Haynes, 1907) p.47580; Alex Frame, Salmond: Southern Jurist (Wellington: Victoria University Press, 1995), p.44-53; Alex Frame, "Salmond, Necessity, and the State," Victoria University of Wellington Law Review 38, 4 (2007), p.23.

${ }^{551}$ Salmond, Jurisprudence, p.200-1.

552 Frame, Salmond, p.167-8; Frame, "Salmond, Necessity, and the State," p.725-7.

${ }^{553}$ Salmond, Jurisprudence, p.111-3; Frame, Salmond, p.207. Furthermore, the New Zealand judiciary had greater power relative to the legislative and executive branches in New Zealand than in Britain, for in New Zealand the Courts had to decide whether the acts and actions of the Dominion Government were invalidated by the law of the sovereign British Government: J. Hight and H.D. Bamford, The Constitutional History and Law of New Zealand (Christchurch: Whitcome and Tombs, 1914), p.362-3.

${ }^{554}$ Sir Hubert Ostler, "Bench and Bar 1903-1928," in Robin Cooke Q.C. ed., Portrait of a Profession: The Centennial Book of the New Zealand Law Society (Wellington: A. H. \& A. W. Reed), 1969, p.72.
} 
allegedly responded "You needn't worry about that. I run the civil service." ${ }^{555}$ Even more concerning, Ostler recalled Salmond having "come straight from hearing the pronouncement of an adverse judgement and draft a clause for the 'washing up' bill, in order to rob his successful opponent by ex post facto legislation of the legal victory he had just won in the courts". ${ }^{556}$

Besides his argument for unlimited executive power, another key feature of Salmond's jurisprudence was his criticism of rigid laws of evidence. In his essay "The History of the Law of Evidence", Salmond advocated that the laws of evidence should be "recognised as rules to be generally observed, but it should be entirely in the discretion of the court to break through them for special reasons in special cases." 557 Salmond repeated this appeal for a "flexible" use of evidence laws in his Jurisprudence. ${ }^{558}$ He even claimed that the privilege from self-incrimination was "destitute of any rational foundation," as "the compulsory examination of the accused" was "an essential feature of sound criminal procedure" - rather ominously concluding that the "innocent" had "nothing to fear from compulsory examination, and everything to gain." 559 Salmond also claimed that it was "not true that hearsay" was "absolutely destitute of evidential value" and rigid laws of evidence were the most defective aspect of British law: "In general, courts of justice should be allowed full liberty to reject as irrelevant, superfluous, or vexatious, whatever evidence they will, and to accept at such valuation as they please whatever evidence seems good to them." 560 These two arguments - for an unlimited executive, and against rigid laws of evidence, would have a significant influence on the New Zealand Government during the First World War, a government in which Salmond served as one of its chief legal officers.

Following stints lecturing at the University of Adelaide, then at the newly established Victoria College in Wellington, Salmond's friend Attorney General John Findlay appointed him first as counsel to the Office of Law Drafting in 1907, then, three years later, as Solicitor General and head of the Crown Law Office. Salmond served in this capacity for ten years,

\footnotetext{
555 Ostler, p.70. Salmond's biographer Alex Frame has questioned the reliability of this oft-quoted remark: Frame, Salmond, p.100.

556 Ostler, p.72.

557 John Salmond, Essays in Jurisprudence and Legal History (London: Stevens and Haynes, 1891), p.69; Frame, Salmond, p.40.

558 Salmond, Jurisprudence, p.26-7.

559 Salmond, Jurisprudence, p.455.

560 Salmond, Jurisprudence, p.457-8.
} 
before his appointment as a judge of the Supreme Court in $1920 .{ }^{561}$ From 1907 to 1920, Salmond was the primary overseer of the exact wording of most government legislation, wielding significant influence on New Zealand law. ${ }^{562}$ By this time, New Zealand had already established a much stronger central executive than the United States. Whereas the American federal system was designed to limit the power of central government, the constitution of the New Zealand state is constructed in a way that allows cabinet to pass interventionist laws with little opposition: Seddon established the legislature as subordinate to the executive, and by the end of the First World War "government by order-in-council" was an "established procedure". ${ }^{563}$ Yet during the first big clash between Stout's classic liberalism and Salmond's paternalism, it was Stout who prevailed.

This clash took place at the Court of Appeal in 1912, during the case Tamihana Korokai v. The Solicitor-General. ${ }^{564}$ The Native Land Act 1909, drafted by Salmond, had made customary Maori land title non-justiciable against the Crown: "the Native customary title to land shall not be available or enforceable as against His Majesty the King by any proceedings in any Court or in any other manner"; furthermore, "A Proclamation by the Governor that any land vested in His Majesty the King is free from the Native customary title shall in all Courts and in all proceedings be accepted as conclusive proof of the fact so proclaimed." 565 Salmond intended to make Maori land claims "political" - to be decided upon by Parliament, not the courts. ${ }^{566}$ Three years later, these clauses were tested when Te Arawa took their claim of fishing rights over Lake Rotorua to the Court of Appeal, arguing that the bed of the lake was "customary Native land in respect of which the Native Land Court has jurisdiction to make freehold orders under the Native Land Act, 1909" - that the "customary

\footnotetext{
${ }^{561}$ Alex Frame, "Salmond, John William", in Dictionary of New Zealand Biography, Te Ara - the Encyclopedia of New Zealand, updated 30-Oct-2012, URL: http://www.TeAra.govt.nz/en/biographies/3s1/salmond-johnwilliam

562 Frame, Salmond, p.96.

563 Leslie Lipson, The Politics of Equality: New Zealand's Adventures in Democracy $2^{\text {nd }}$ edn. (Wellington: Victoria University Press, 2011), p.239-41, 295; Duncan Webb, Katherine Sanders and Paul Scott, The New Zealand Legal System - Structures and Processes $5^{\text {th }}$ edn. (Wellington: Lexis Nexis New Zealand Limited, 2010), p.12431.

564 N.Z.L.R. 1912, vol.32, p.321-59.

565 Native Land Act 1909, s84-5.

${ }^{566}$ Frame, Salmond, p.115.
} 
and exclusive rights of fishing" in the lake, held by Te Arawa, were "capable in some manner of legal recognition and enforcement" by the Native Land Court. ${ }^{567}$

Salmond argued that sections 84 and 85 of the Native Land Act meant that this was not the case: "the contention of the Crown is that the Natives may go to the Native Land Court and ask to have their customary rights investigated and determined, but if the Crown claims the land is Crown land then the Court's jurisdiction is ousted." 568 Furthermore, Native title was "not available in any manner and for any purpose against the Crown. As against the Crown it is not a legal title at all", and when a dispute existed as to whether any land was "Native customary land or Crown land", the dispute could not be litigated in any Court. ${ }^{569}$ Against the claim that Native title was guaranteed by the Treaty of Waitangi, Salmond claimed that the Treaty was "not an international treaty but merely a contract with certain individuals and in force only over the lands of those signing the treaty", that it was "not examinable in any Court of law", could not "be the basis of any action in any Court of law", and that "Any statutory recognition of Native title" was "irrelevant." 570 When Justice Cooper pointed out that this meant the "Crown could then eject Natives from their customary lands", Salmond agreed that this was "a necessary result of the principle." 571

In deciding the case, Chief-Justice Stout noted that the "only question" the Court had to rule on was the validity of Salmond's contention "that if he, as Solicitor-General, says the land that is, the bed of Lake Rotorua - is Crown land, that concludes the matter, and the Native Land Court cannot proceed to make any inquiries as to whether the land is Native customary land." 572 Stout went on to note that while the Crown had at times interfered with Native title, such interference was "based on the theory of eminent domain": this same theory had been used to justify Crown interference in land title within the United Kingdom, and such interference did not make Native title any weaker than other freehold title. "To interfere with Native lands merely because they are Native lands and without compensation would, of course, be such an act of spoliation and tyranny that this Court ought not to

\footnotetext{
567 N.Z.L.R. 1912, vol.32, p.324-5.

568 N.Z.L.R. 1912, vol.32, p.329.

569 N.Z.L.R. 1912, vol.32, p.331.

570 N.Z.L.R. 1912, vol.32, p.333-4.

571 Ibid.

572 N.Z.L.R. 1912, vol.32, p.338.
} 
assume it to be possible in any civilized community." 573 Stout concluded that neither the Solicitor-General, nor the Attorney-General, had statutory authority to declare any land to be Crown land, and that therefore Te Arawa's claim to "the bed of Lake Rotorua" should be decided upon by "the only Court in New Zealand that has jurisdiction to deal with Native titles - the Native Land Court." ${ }^{574}$ Stout's fellow judges agreed, but Salmond could not accept defeat: a week later, when the Court met again to decide upon costs for the case, Salmond insisted upon repeating his claim that Native title should not be enforceable against the Crown in the Native Land Court. ${ }^{575}$

Five years later, Stout and Salmond again clashed in Court over the question of executive power. By this time, Parliament had passed a series of significant legislative measures intended to give the executive greater power to govern by orders-in-council in matters relating to the war. One of these measures was tested before the Supreme Court in the case Taratahi Dairy Co. Ltd. and Mangorei Dairy Co. Ltd. v. Attorney General. ${ }^{576}$ Using powers granted by the Regulation of Trade and Commerce Act 1914, the executive, by an order-incouncil, had restricted butter exports and placed a levy on exports in order to reduce the cost of butter sold domestically; two dairy companies objected that this levy, having not been voted upon in Parliament, amounted to taxation without representation.

Arguing for the Executive's ability to "override by way of regulations any Act on the statutebook", Solicitor-General Salmond argued that a combination of "Royal prerogative" and "special legislation" - particularly the War Regulations Act - meant that Parliament had "entrusted such powers as were never heard of before to the Executive, without any express limitations or qualifications". Salmond admitted that such a "constitutional revolution" meant the country was "living at present under a despotic Government" and that it was "easy to call attention to grave evils which might possibly result" from this situation, but that nevertheless such despotism was necessitated by the "national emergency." 577

\footnotetext{
573 N.Z.L.R. 1912, vol.32, p.343-4.

574 N.Z.L.R. 1912, vol.32, p.345.

575 Frame, Salmond, p.117-8.

${ }^{576}$ N.Z.L.R. 1917, vol.36, p.1-39; see previous discussion of this case in the Economy chapter of this thesis.

577 N.Z.L.R. 1917, vol.36, p.9, 12.
} 
In response to Salmond's claim that wartime powers allowed the Executive to "override by way of regulations any Act on the statute-book", Chief Justice Stout interrupted that the Government could not "override the Constitution Act"; the representative of the plaintiffs, not disputing that the Legislature had conferred "very wide powers on the Executive", argued that such powers were "given under express statutory authority" with clearlydefined limits. ${ }^{578}$ Stout agreed, arguing that as the powers conferred on the Governor-inCouncil by the Regulation of Trade and Commerce Act were an extension of powers created by the Customs Act 1913, they were not really emergency wartime powers, and certainly did not allow the Executive to levy taxation without the assent of Parliament. Stout concluded that he was "unaware of any case or of any statement in any text-book" upholding the argument "that we must apply a different rule in war-times from what we do in peace-times in construing a statute". To Stout, the argument that war justified "the destruction of the safeguards of our liberty that our ancestors won for us through trials and tribulations" was false, and removing such safeguards was both "unconstitutional and illegal." 579

Ultimately, Stout was in the minority on this case. Although his two fellow Justices based their decision to find in favour of the Crown largely on the basis that the Executive's actions at the centre of the case did not in fact constitute a tax, Justice Chapman also presented an argument for taking the Solicitor-General's interpretation of emergency powers, rather than that of the Chief Justice. As the British Empire "had to face the greatest peril to which it had ever been exposed," Parliament had "decided to entrust the Government with unusual powers." The various war statutes "either interfered with the rights of the subject or otherwise greatly extended the powers of the Executive, perhaps to the extent of authorizing the Governor to suspend the Habeas Corpus Act." 580 While Stout discussed the similarity between the powers conferred by the wartime Regulation of Trade and Commerce Act and the peacetime Customs Act, Chapman concluded that the former Act had to be considered "an emergency Act of an exceptional character" purely on the basis that its provisions would expire with the termination of the conflict. ${ }^{581}$ Thus, in spite of

\footnotetext{
578 Ibid.

${ }^{579}$ N.Z.L.R. 1917, vol.36, p.14, 17-9, 22.

580 N.Z.L.R. 1917, vol.36, p.32.

${ }^{581}$ N.Z.L.R. 1917, vol.36, p.32-3.
} 
dissent from one of the very highest judicial authorities, the Supreme Court ultimately upheld the Executive's ability to suspend an "ancient bulwark of British liberties".582 Consequently, contrasting these two cases, from 1912 and 1917, gives us a basic picture of how the context of wartime emergency expanded the accepted legal limits of state power.

\section{Demilitarisation Interrupted}

While New Zealand's involvement in "total war" from August 1914 required judicial, policing and penitentiary institutions to involve themselves in new military responsibilities, the Dominion's justice system already had a long and complicated relationship with the country's defence forces. The story of this relationship is not a simple narrative of progressive demilitarisation. The colony-wide Constabulary Force established in 1877 was a dual military and police force, consisting of a civil policing wing and a military reserve. For the first two decades, all Commissioners of the Force were military officers, and only members of the military reserve were eligible to enrol in the police wing; although the two forces were formally separated into a Police Force and Permanent Artillery in 1886, all police recruits had to first serve in the Artillery until a lack of spare Artillerymen led to the abolition of this requirement in 1897. In 1896 responsibility for the Police was moved from the Minister of Defence to the Minister of Justice, and the following year a non-military man, J. B. Tunbridge of the London Metropolitan Police, was appointed Commissioner; the Commission of Inquiry into policing matters conducted over the following year frequently heard complaints that recruits from the military were too prone to drink and violence. ${ }^{583}$ This demilitarisation reflected a society which had become increasingly harmonious and law-abiding since the end of the Land Wars: in the first twenty years after the abolition of the provinces, the number of recorded offences in New Zealand fell by one third. ${ }^{584}$

However, the demilitarisation of policing was interrupted almost immediately by the massive popularity of the 1899-1902 Anglo-Boer War, and subsequent proclamations by

\footnotetext{
${ }^{582}$ N.Z.L.R. 1917, vol.36, p.14.

583 Tristan Egarr, "Discipline and Defence: The Military Influence on Policing and Imprisonment, c.1870-1913" (MA Thesis, Victoria University of Wellington, 2010), p.21, 50-7; Hill, The Iron Hand in the Velvet Glove. 584 The Number of Recorded Offences per 1000 population fell from 32.74 in 1878 to 20.18 in 1897: Egarr, p.15. Note that this table incorrectly states "Offences per 100,000 population" where it should state "per 1000 population".
} 
policing and prison administrators that returned servicemen made the best constables and guards. A decade later, during another Commission of Inquiry, these recruits once again came under criticism for being too forceful and undisciplined, suggesting a return to demilitarisation. ${ }^{585}$ But, once again, this trend was interrupted by the course of events. Compulsory Military Service, introduced in 1909, required police to round up and incarcerate defaulters, thus effectively recruiting the infrastructure of civil justice to enforce military duties. During the industrial disputes of 1913, the Massey Government relied on military officers to recruit and train special constables for strike breaking. ${ }^{586}$ So when war broke out the following August, the use of police to enforce military regulation and the use of military forces in civil policing had both already been extended.

Although police uniforms were partially demilitarised in 1912, with a London Metropolitanstyle helmet replacing the shako, "proper military" collars were retained, and in 1916 military-style caps were issued to mounted police. ${ }^{587}$ Unmarried officers in the cities were still required to live in barracks, where military discipline prevailed: under regulations in force in 1920, officers were subject to daily inspections to ensure their beds were made; men not on leave or duty had to be in bed at 11 p.m. with lights out half an hour later; liquor, gambling, and profane language were prohibited, smoking was prohibited in bedrooms, and the hanging of pictures and admission of visitors were strictly regulated. ${ }^{588}$ When in uniform, constables were required to salute not just their superior officers and magistrates, but all commissioned officers of the Royal Navy, the Imperial Army, and the New Zealand Military. Police "marching on duty" could be forced to obey the commands "eyes right," "eyes left" or "eyes front". 589 In September 1917, police were detailed to assist the Navy in enforcing war regulations on wharves and ships. ${ }^{590}$ While Superintendent John Dwyer noted that policemen of the 1880s were "obliged to keep up a much stricter military appearance and discipline" than those active during the war, other officers appearing

\footnotetext{
585 Egarr, p.65-9.

${ }^{586}$ Egarr, p.77-88.

587 Hill, The Iron Hand in the Velvet Glove, p.424.

588 "Barracks and Barrack Regulations," in The Police Force Act, 1913, Police Force Amendment Act, 1919, and Regulations (Wellington: Government Printer, 1920), p.41-9.

589 "Saluting", in The Police Force Act, 1913, Police Force Amendment Act, 1919, and Regulations, p.136-7.

${ }^{590}$ AJHR 1918, H-16, p.7.
} 
before the 1919 Police Commission noted that "military discipline" still had to be "kept up", and claimed that the Police Force was still "more or less in the nature of a military body." 591

Unsurprisingly, given this description of the police as a branch of the military forces, officers were keen to sign up for the New Zealand Expeditionary Force. This created problems or the Justice Department, as those who would have replaced departing officers in peacetime also sought military adventure instead, and the training depot was closed in December 1916, the same month in which the army were forced to abstain from recruiting any policemen eligible for military service. ${ }^{592}$ The absence of willing recruits meant the Commissioner refused to allow policemen to join the Expeditionary Forces, although he could not prevent officers from resigning from the police, and subsequently enlisting to join the army from civilian life. ${ }^{593}$ In spite of their "training and discipline" making returned servicemen ideal recruits in the eyes of the policing authorities, few of those who returned to New Zealand before war's end applied to join the Force, either due to injury and ill-health, or the number of better employment opportunities the war opened up..$^{594}$

To cope with the lack of recruits at a time when police had to enforce wartime measures such as the Military Service Act and new liquor regulations - in addition to the peacetime laws - the Government included a provision in the War Legislation Amendment Act 1916 allowing the Commissioner to appoint temporary constables who would otherwise be ineligible for service, due to infirmity or advanced age. Although such officers were given "all the rights, powers, protection, and privilege" of regular constables, they were not to retain their positions beyond twelve months after the end of the war. ${ }^{595}$ Although former constables who had resigned to fight in the war were reappointed in large numbers, and returned servicemen were again encouraged to enlist in the police, the total number of police - including temporary constables - fell from 916 in 1916 to 878 in 1919.596 Consequently, a Police Force Amendment Act of 1919 not only restored the promotion and superannuation rights of officers who had resigned to fight, but also permanently extended

\footnotetext{
5911919 Police Commission, p.228, 242, 292.

592 AJHR 1917, H-16, p.7; 1918, H-16, p.6.

${ }^{593}$ AJHR 1915, H-16, p.6-7; Hill, The Iron Hand in the Velvet Glove, p.338-9.

${ }^{594}$ AJHR 1917, H-16, p.7.

595 Ibid; War Legislation Amendment Act 1916, s32.

${ }^{596}$ AJHR 1919, H-16, p.7; 1930, H-16, p.5.
} 
the Commissioner's ability to appoint temporary constables. ${ }^{597}$ This latter measure allowed those appointed during the war to stay on in spite of old age or other issues. ${ }^{598}$ Wartime conditions meant police had a greater involvement in military duties, but it also relaxed standards and diluted numbers.

\section{The Rigid Discipline of Commissioner Cullen}

Not all police were happy with the ongoing military discipline and violent tactics the Commissioner expected. In 1913, the Maoriland Worker published an open letter to the Minister of Justice by a "plain-clothes" officer. The correspondent claimed that the contemporaneous agitation for a police union was a direct result of the fatal violence officers were asked to perpetrate in putting down industrial conflict at Waihi the previous year. ${ }^{599}$ In April 1913, about fifty Auckland policemen formed the New Zealand Police Association to agitate for better pay and conditions. With the support of the Minister of Justice, Police Commissioner John Cullen crushed the Association and drove supposed ringleaders out of the force, citing a regulation forbidding "combinations" among officers. However, to pre-empt further agitation, Herdman made it known that police could seek some representation in the fledgling Public Service Association. ${ }^{600}$ Despite this concession, Herdman and, especially, Cullen demonstrated an intolerance of dissent, and remained hostile to officers using even sanctioned PSA representatives to agitate for better conditions. ${ }^{601}$

Historians have characterised John Cullen as not merely a strict disciplinarian, but a vindictive man. According to Mark Derby, “Cullen's sharp tongue and short temper had made him widely feared and actively disliked while his insistence on military-style discipline ran counter to national efforts to modernise policing practice"; his "propensity for inciting public disorder for political ends reached its apotheosis" when he gave one Waihi striker a

\footnotetext{
597 Police Force Amendment Act 1919, s2, s6.

598 Dunstall, A Policeman's Paradise?, p.47-8.

${ }^{599}$ Maoriland Worker, 23 May 1913, p.4.

600 Hill, The Iron Hand in the Velvet Glove, p.297-303.

${ }^{601}$ Hill, The Iron Hand in the Velvet Glove, p.375-7.
} 
personal "hiding". ${ }^{602}$ Richard Hill claims that Cullen's time as Inspector of the Auckland District was marked by "serious indiscretions, which included open feuds with subordinates and important local figures" as well as "vindictiveness towards the many he had fallen out with"; Cullen blamed his failure to achieve the post of Commissioner in 1909 on "antiCatholic influence." 603 Three years later, his "infamous propensity for quarrelling" and a "too-confrontational image" once again led the Government to resist appointing him Commissioner, but his reputation as a steady hand at controlling dissent ultimately led him to become the first head of New Zealand's Police Force to have risen from the rank of Constable. To maintain discipline, Cullen used trusted subordinates to spy on other officers, and had previously stated his opposition to policemen being allowed to vote. ${ }^{604}$

Born into dire poverty in northern Ireland, Cullen served seven years in the paramilitary Royal Irish Constabulary before emigrating "to seek his fortune", and joined the New Zealand Constabulary during its inaugural year. ${ }^{605}$ In Ireland, Cullen could not have hoped to rise beyond Sergeant; in New Zealand, after making his name in an undercover raid on King County sly-groggers, Cullen made Inspector after two decades' service. ${ }^{606}$ Appointed Commissioner three months before Reform came to power, Cullen was a personal friend of Herdman, with whom he shared a vehement dislike of any display of disloyalty, an animosity perhaps increased during the war when three of his sons joined the Expeditionary Forces, with one dying in battle. ${ }^{607}$ Although all officers were required by law to retire upon their sixty-fifth birthday, Herdman used the "special circumstances" clause of the Police Force Act to extend Cullen's Commissionership for six months, to 23 November 1916. He was then appointed Commissioner of Aliens under the Defence Department, to oversee the surveillance and compulsory employment of unnaturalised "enemy" aliens who were not considered sufficient threat to require incarceration, finally retiring from state service in 1919. ${ }^{608}$

\footnotetext{
${ }^{602}$ Mark Derby, The Prophet and the Policeman: The Story of Rua Kenana and John Cullen (Nelson: Craig Potton Publishing, 2009), p.48, 51.

${ }^{603}$ Richard S. Hill, "Cullen, John," in Dictionary of New Zealand Biography, updated 30 October 2012, URL: http://www.TeAra.govt.nz/en/biographies/3c42/cullen-john

$604 \mathrm{Hill}$, The Iron Hand in the Velvet Glove, p.273-5.

605 Hill, The Iron Hand in the Velvet Glove, p.274; Hill, “Cullen, John”; Derby, p.23-4. 27.

606 Hill, “Cullen, John”; Derby, p.27, 33.

607 Derby, p.75-6.

608 Police Force Act 1913, s26; Hill, “Cullen, John”; Baker, p.222-3.
} 
Cullen's replacement as Commissioner, John O'Donovan, was a fellow Irish Catholic, but could not be further from his predecessor in temperament: a widely-read, qualified solicitor with a "gentle manner and fine sensibilities", O’Donovan was physically unimposing, and on his death attracted notice for his "unvarying courtesy and consideration to his men", epitomised by his retiring early in order to "ease the pressure on those below". ${ }^{609}$ Responding to requests from his men, O'Donovan increased pay; clarified that officers did have permission to join the Public Service Association; drew attention to substandard police housing and inadequate compensation for police widows and orphans; and substituted 8hour day-shifts for the previous system of two 4-hour shifts interrupted by a 4-hour break, thus providing his men with "more time to devote to their homes and recreation." 610 Yet like Cullen, O'Donovan saw the success of his attempts to ensure order in a time of "exceptional stress and difficulty" as relying upon the "firm application of the war regulations" and the extension of these measures into the peace, implementing a programme of systematic spying on labour activists. ${ }^{611}$ He described the policeman as a soldier of peace, providing "heroism without the limelight" and often paying for the "privilege" with his life: O'Donovan called the death of one constable in the line of duty "an epic incident of the internal war that goes on always, and which is even more necessary than is external war to the safety of the state." ${ }^{612}$

John Cullen noticeably tightened the military standards of police discipline which had relaxed under the civilian leadership of the post-1898 era. While the "higher standards" he imposed reflected a context of "civil strife" and "war emergency" requirements, Richard Hill argued that "they were also tied to the concept of police as moral exemplars" but that "Cullen's high 'moral' requirements sat uneasily alongside his authoritarian attitude towards the citizenry." 613 Wartime regulations and falling police numbers brought fuelled conflict between officers and civilians, fanning the flames stoked by the violent industrial confrontations of the immediate pre-war years - particularly once anti-"shouting" legislation and six o'clock bar closing kicked in. Suspect minorities - Maori from tribes who did not

\footnotetext{
${ }^{609}$ Evening Post, 8 April 1927, p.10; Dominion, 9 April 1927, p.10; Graeme Dunstall, “O'Donovan, John," in Dictionary of New Zealand Biography, updated 30 October 2012, URL: http://www.TeAra.govt.nz/en/biographies/3o2/odonovan-john ${ }^{610}$ AJHR 1919, H-16, p.7-9; 1920, H-16, p.7; Police Gazette 1919, p.427.

${ }^{611}$ Dunstall, A Policeman's Paradise?, p.43; Dunstall, “O’Donovan, John”; AJHR 1921, H-16, p.8.

612 Evening Post, 11 October 1919, p.4.

${ }^{613}$ Hill, The Iron Hand in the Velvet Glove, p.328.
} 
support the war effort, militant trade unions, prostitutes and drunks - faced increased persecution. In spite of all these factors, the total number of offences reported per year fell from 27,563 in 1914 to 19,067 in $1918 .{ }^{614}$ The absence overseas of many of the most frequently arrested population group - young men - helps explain this decline, especially since the number of reported offences quickly rose again, to 26,106 in 1920, once the men returned - but the absence of police to report on crime is another factor. ${ }^{615}$ Ultimately, however, while we must avoid interpreting crime statistics as a direct correlation of behaviour, it is reasonable to postulate an increasingly obedient mainstream acquiescing to the behaviour demanded of loyal subjects in a time of war, coupled with increased persecution of those on the margins.

\section{Wartime Legislation: The "destruction of the constitutional system on which all British Parliaments have been founded." $\underline{616}$}

Cullen's tight control of the force was aided by John Salmond and Alexander Herdman's attitude towards the law, in particular their willingness to play loose with the law of evidence. During the industrial conflict of 1913, the Reform Government had already begun removing traditional restrictions on the powers of the Executive; the outbreak of war simply confirmed this trend. The Police Force Act 1913 allowed "common reputation" to be deemed evidence of a police officer's right "to hold or execute his office", and required that no other evidence, including written documentation, need be produced. ${ }^{617}$ Nothing like this section appeared in the previous Police Force Act, and its addition suggests that the Reform Government - backed up by the authority of their chief legal theorist, Solicitor-General John Salmond - was impatient with the law of evidence. ${ }^{618}$ Over the next five years, legislation passed specifically to deal with war matters routinely contained provisions allowing the admissibility of all evidence, regardless of precedent.

\footnotetext{
${ }^{614}$ AJHR 1930, H-16, p.5.

615 Ibid.

${ }^{616}$ Sir Robert Stout: N.Z.L.R. 1917, vol.36, p.17.

617 Police Act 1913, s12.

618 Police Force Act 1908.
} 
Section 19 of the Regulation of Trade and Commerce Act 1914, which passed into law six days after the British Empire declared war, removed all restrictions regarding the admissibility of evidence in cases arising from the Act:

"In any action for the recovery of a penalty or for an injunction under the forgoing provisions of this Act the Supreme Court may, in proof of any fact in issue, admit and accept as sufficient such evidence as it thinks fit, whether such evidence is legally admissible in other proceedings or not." ${ }^{619}$

This relaxation of the law of evidence was not a wartime measure; rather, it extended powers provided by an amended Customs Act of the previous year:

In all actions and other proceedings under the Customs Acts, whether civil or criminal (other than prosecutions for an indictable offence), the Court may in proof of any fact in issue admit and accept as sufficient such evidence as it thinks fit, whether such evidence is legally admissible in other proceedings or not. ${ }^{620}$

No such statement appeared in the Customs Law Act in the Consolidated Statutes of 1908, suggesting that the Government's moves to relax the laws of evidence during the war were motivated by the legal attitudes of that particular Cabinet.

Major restrictions embodied in the Evidence Act 1908 include a prohibition against "needlessly offensive" questioning; the privilege from self-incrimination; and the confidentiality of communications made between spouses, between patients and their doctors, or in confessions to a minister. ${ }^{621}$ The law of evidence is "largely judge-made", and statutory provisions such as those listed above merely supplement the general principle: that only "logically relevant evidence" is admissible, and that such evidence must not create "unfair prejudice, misleading or confusing effect" or be "time-wasting." 622 While section 19 of the Regulation of Trade and Commerce Act appears to abandon such restrictions, it is

\footnotetext{
${ }^{619}$ Regulation of Trade and Commerce Act 1914, s19.

${ }^{620}$ Customs Act 1913, s280.

${ }^{621}$ Evidence Act 1908, s5; s6-8; s14.

${ }^{622}$ NZLC R55 - Volume 1, p.1-2, 7-8.
} 
followed by a more specific section (absent from the Customs Act) regarding the privilege against self-incrimination alone: ${ }^{623}$

\begin{abstract}
"In any action for the recovery of a penalty or for an injunction under the forgoing provisions of this Act no person, whether a party to the action or not, shall be excused from answering any question put to him by interrogatory or otherwise, or from producing or making discovery of any document, on the ground that the answer to the question or the production or discovery of the document would tend to incriminate him in respect of any offence against this Act." 624
\end{abstract}

That such a specific addition was considered necessary suggests that the vague powers admitting all evidence contained in section 19 may not have suspended such aspects of the Evidence Act as the privilege against self-incrimination, and were more concerned with relevance. The abrogation of the privilege against self-incrimination created by section 20 was alluded to in the debate over the Act, when Labour member Bill Veitch stated that "a Royal Commission has not the power to compel people to give evidence; and I think such a Commission or Commissions as are suggested in this Bill should have such power." Herdman replied that any Commission created by the Act would have "all the powers provided under the Commissions of Inquiry Act, 1908", and Massey stated that a Commission of Inquiry had "sufficient power" to "compel evidence", that witnesses appearing before an inquiry could "be compelled to give evidence on oath." 625

\footnotetext{
${ }^{623}$ This privilege, while popularly regarded as a traditional right stretching back at least to the seventeenth century, was really only confirmed by the legal reforms of early-nineteenth century Britain: John H. Langbein, "The Historical Origins of the Privilege Against Self-Incrimination at Common Law," Michigan Law Review 92 (1993-4), p.1047; Henry E. Smith, "The Modern Privilege: Its Nineteenth-Century Origins," in R.H. Helmholz, Charles M. Gray, John H. Langbein, Eben Moglen, Henry E. Smith, Albert W. Alschuter ed., The Privilege Against Self-Incrimination: Its Origins and Development (Chicago: University of Chicago Press, 1997), p.145-8. The privilege is specifically abrogated only once in the New Zealand Consolidated Statutes 1908 - in the Gaming Act, s65.

${ }^{624}$ Regulation of Trade and Commerce Act 1914, s20. This presumably also suspends the privilege of spousal incrimination, which is an offshoot of the privilege against self-incrimination and only logical when the latter privilege exists.

${ }^{625}$ NZPD 1914, vol.169, p.476.
} 
Massey was mistaken. The Commissions of Inquiry Act 1908 provided "the same privileges and immunities as witnesses and counsels in Courts of law" to all witnesses summoned before a Commission of Inquiry. ${ }^{626}$ It seems logical to presume, then, that sections 19 and 20 of the Regulation of Trade and Commerce Act were an attempt to clarify that any Commission created under the Act would indeed have the power to compel witnesses to testify, regardless of the restrictions imposed by the Evidence Act. Yet if these sections had been inserted after Veitch's question, their insertion would be detailed in Hansard, which is not the case. It is baffling, then, that Herdman did not simply refer Veitch to these sections. ${ }^{627}$

Two months later, the Government passed a War Regulations Act, allowing the Governor in Council to make regulations prohibiting acts considered "injurious to the public safety, the defence of New Zealand, or the effective conduct of the military or naval operations of His Majesty during the war." ${ }^{628}$ As legislators then believed the war would be of short duration, the Act expired after a year, consequently requiring an amendment to extent its provisions. This War Regulations Amendment Act, beyond simply extending the principle Act, also contained language very similar to that of section 19 of the Regulation of Trade and Commerce Act:

\footnotetext{
"In any prosecution under the principal Act the Court may admit such evidence as it thinks fit, whether such evidence is legally admissible in other proceedings or not." ${ }^{\prime \prime 29}$
}

Uniquely, on this occasion Herdman provided an explanation of the powers suspending the law of evidence:

\footnotetext{
${ }^{626}$ Commissions of Inquiry Act 1908, s6.

${ }^{627}$ Furthermore, had sections 19 and 20 been inserted after this exchange, Massey's earlier references to later sections of the bill would use numbering different to that which appears in the final version as enacted - which is also not the case: NZPD 1914, vol.169, p.473.

${ }^{628}$ War Regulations Act 1914, s3.

${ }^{629}$ War Regulations Amendment Act 1915, s3.
} 
"Clause 3 provides that the ordinary legal rules relating to the taking of evidence may be relaxed, and that matters which are, strictly speaking, not evidence in legal proceedings shall be taken in evidence in Court in considering any proceedings under the War Regulations Act. That provision is not new, for it is frequently seen in more modern legislation. It is found that it is not desirable to adhere to the strict rules of evidence when proof of certain matters is required." 630

While such clauses were not unprecedented prior to the war - as the Customs Act demonstrates - they appear in only two of the 208 statutes consolidated in 1908 - the Destitute Persons Act, and the Old-Age Pensions Act - which casts doubt on Herdman's claims to their frequency. ${ }^{631}$ Furthermore, of the two pieces of Liberal legislation in which such clauses appear, the latter relates to investigations enabling payments, not to prosecutions. The Reform Government's routine insertion of such sections into legislation regulating trade and property continued with part one of the War Legislation Act 1917, prohibiting the acquisition of land by enemy aliens:

\begin{abstract}
"In all proceedings under this Part of the Act, and in all proceedings in which any question arises as to the title to any estate or interest in land as dependent on the nationality of any person, the Supreme Court may, in proof of such nationality, accept such evidence as it thinks fit, whether such evidence is admissible in accordance with the law of evidence or not." 632
\end{abstract}

\footnotetext{
${ }^{630}$ NZPD 1915, vol.172, p.89. Perhaps the most salient point in this entire discussion is exactly what frequent modern legislation Herdman is referring to; I have not seen this clause in any statutes not relating to the war, and am unsure how to test his assertion.

${ }^{631}$ Destitute Persons Act 1908, s41: "In proceedings under this Act the Magistrate may receive any evidence he thinks fit, whether the same is strictly legal evidence or not." Adapted from Destitute Persons Act 1894, s42. Old-age Pensions Act 1908, s27 (1.): "In investigating any claim for a pension or pension-certificate, the Magistrate shall not be bound by the strict rules of evidence, but shall investigate and determine the matter by such means and in such manner as in equity and good conscience he thinks fit." Adapted from Old-age Pensions Act 1898, s24.

${ }^{632}$ War Legislation Act 1917, s8. An almost identical statement appears in the Acquisition of Land by Persons of Enemy Origin part of the post-war War Legislation and Statute Law Amendment Act 1918, s.8, thus extending this abrogation beyond the termination of the conflict.
} 
That neither of these sections were followed by one allowing magistrates to compel witnesses to give evidence do not mean that they did not abrogate the privilege against selfincrimination, but rather than this particular power was considered specially relevant to the Regulation of Trade and Commerce Act (due to the technical nature of investigations arising from that act). Exactly what powers these Acts gave to magistrates to ignore the law of evidence was never tested in the High Court, Supreme Court or Court of Appeal. The New Zealand Law Review for the period in which war legislation was in place contain four discussions of the law of evidence, none of which relate to war legislation. ${ }^{633}$ The absence of discussion in parliament of the suspension of evidence in war legislation suggests that Members of Parliament were content to extent such extraordinary powers to judges due to the extraordinary circumstances of war; on the other hand, that absence of any appeal arising from the suspension of the law of evidence in cases arising from such legislation might tempt us to believe that judges chose not to exercise such powers, or at least exercised them with tact.

However, one man did take a stand against the suspension of the law of evidence, and documented the impact of this suspension on men accused of crimes under war legislation: the socialist editor of the Maoriland Worker, Harry Holland. On 2 October 1917, the general secretary of the Federated Seamen's Union, W. T. Young, and his assistant, F. C. Howell, were convicted in Wellington District Court of inciting a seditious strike, under the War Regulations Act. No witnesses were called to testify that either man had incited them to strike; the police and prosecution instead relied upon hearsay evidence to gain a conviction. Young told the court "that if the law of evidence had been strictly adhered to neither of them would have been convicted." 634 Two weeks later, Holland penned an editorial railing against "the injustice of making it possible to convict accused men on hearsay evidence only - evidence which, if unsupported, would not have carried any weight whatever in a British Court prior to this war, and, indeed, would have had no chance of being admitted." Holland argued that the War Regulations granting the "power to accept hearsay evidence" constituted "the most dangerous as well as the most vicious form of legislation known in

\footnotetext{
633 N.Z.L.R. 1914, vol.33, p.585; 1917, vol.36, p.440, 598; 1918, vol.37, p.401.

${ }^{634}$ Maoriland Worker, 10 October 1917, p.3.
} 
modern political history", and concluded that this power "must certainly be withdrawn" if the country's "law courts" were "to have a chance to function as courts of justice as well." 635

Following Young and Howell's release from the Terrace Gaol the in January 1918, they were toasted by the Wellington Branch of the Federated Seamen's Union. Patrick Joseph O'Regan, proposing the toast, also offered a protest against the War Regulations, which he said "looked like part of a settled policy of attack on the jury system," warning the audience to "cherish and defend that system." 636 Having publicised and opposed the admission of hearsay evidence by printing these arguments in his newspaper, Holland also became the first Member of Parliament to draw attention to the changes to the law of evidence. ${ }^{637}$ When Grey MP Paddy Webb was gaoled under the Military Service Act in March 1918, Holland stood for and won his seat two months later. Though he had no formal legal training, Holland's "voracious and indiscriminate reading" gave him a greater understanding of the law than his fellow Labour MPs. This made him a more effective critic of the Government's alterations to the justice system, and helped him rise to become the party's leader. ${ }^{638}$

Judges in courts of law were not the only officials to receive extraordinary powers to admit evidence. The Military Service Boards set up to hear appeals against conscription could " admit and accept such evidence" as they thought fit, "whether admissible in a Court of law or not." 639 While any conscript whose appeal was rejected on the basis of spurious evidence could have appealed to the Supreme Court, such an appeal would have had little chance of success: in one of his first decisions as a Supreme Court Justice, Herdman refused to rule on a man's appeal against conscription, on the grounds that "to decide the question would be to interfere in the functions specially entrusted to Military Service Boards". ${ }^{640}$

\footnotetext{
635 Maoriland Worker, 17 October 1917, p.4.

${ }^{636}$ Maoriland Worker, 16 January 1918, p.5.

637 NZPD 1918, vol.183, 30 October, p.93.

638 Patrick O'Farrell, "Holland, Henry Edmund", in Dictionary of New Zealand Biography, Te Ara - the Encyclopedia of New Zealand, updated 30-Oct-2012, URL:

http://www.TeAra.govt.nz/en/biographies/3h32/holland-henry-edmund

639 Military Service Act 1916, s21.

640 The appeal arose from the plaintiff's contention that "he was not resident in New Zealand within the meaning" of the Military Service Act: N.Z.L.R. 1918, vol.37, p.506.
} 
Besides interfering with the law of evidence, some of New Zealand's war legislation also reversed the burden of proof. The Defence Act 1909, establishing compulsory military service, required employers, suspected of punishing workers for adhering to the requirements of the Act, to prove that their employee had been "penalised for some reason other than for having rendered the personal service required of him". ${ }^{641}$ The Military Service Act 1916 and Social Hygiene Act 1917 similarly placed the burden of proof on employers to show that they were not guilty of certain offences. Under the Social Hygiene Act, anyone who employed or continued to employ "any person suffering from any venereal disease in a communicable form" in the handling or preparation of food, was required to prove that they "did not know or suspect, and had no reasonable means of knowing or suspecting, that the person so employed" was suffering from such a disease. ${ }^{642}$

The Military Service Act required anyone who employed a member of the Reserve who had failed to enrol when called upon, or employed any man who had deserted or was absent without leave from the Expeditionary Force, to prove that they were unaware of their employee's situation. ${ }^{643}$ The same Act also required any Reservist who failed to submit themselves for medical examination, when called upon to do so, to prove that they had reasonable cause for such failure. ${ }^{644}$ Furthermore, in any prosecution arising from the Act, if question arose as to whether a man was indeed a member of the Reserve - "or of any division or class the enrolment of which has been directed, or has been called up from the Reserve for service with the Expeditionary Force, or has been attached to any unit thereof" the "affirmative" would "be presumed until the contrary is proved." Likewise, when any question arose as to whether the accused had "received any discharge, exemption, or permission", or had "made any application or fulfilled any obligation required from or imposed on him by this Act or by the National Registration Act", the "negative" would "be presumed until the contrary is proved." ${ }^{645}$ This dual-reversal of the burden of proof suggests that the Government considered the efficient administration of military justice to override historical protections for defendants. However, unlike the relaxation of the laws of

\footnotetext{
${ }^{641}$ Defence Act 1909, s52 (2.)

${ }^{642}$ I have called this Act "war legislation" as it was a response to the specific war-time concern to protect New Zealand women from venereal disease contracted by soldiers fighting overseas. Social Hygiene Act 1917, s6.

${ }^{643}$ Military Service Act 1916, s40-41.

${ }^{644}$ Military Service Act 1916, s7 (3.).

${ }^{645}$ Military Service Act 1916, s38.
} 
evidence, reversal of the burden of proof was a frequent practice prior to the outbreak of the war.

Presenting the War Regulations Act 1914, Francis Dillon Bell stated that he "need not say that any power" the Government asked for "no doubt would be given"; his only doubt was whether they had "gone far enough in asking for the powers". ${ }^{646}$ The Act passed without debate or dissent in either House, and as Bell predicted, the powers it granted were indeed expanded over the next four years: this expansion of executive power was amply demonstrated in the case of Taratahi Dairy Co. Ltd. and Mangorei Dairy Co. Ltd. v. Attorney General, cited earlier in this chapter.

\section{Arrest Without Warrant}

Unlike the evidence laws, attempts to give police power to arrest without warrant, though not unprecedented, ran into strong opposition when included in Military Service Act. The very first regulation issued under the War Regulations Act 1914 gave police power to arrest without warrant anyone whom they "reasonably suspected" had either breached or was about to breach any war regulation, or acted in any manner "injurious to the public safety or the interests of His Majesty in respect of the present war."647 This regulation provoked no opposition in parliament, but two years later when section 44 of the Military Service Act gave police the power to arrest without warrant any man of military age who failed to satisfactorily answer their questions, several Members of the House of Representatives including some of those who supported conscription - objected.

Shortly before speaking out against conscientious objectors, Reform Member A.K. Newman asked Massey and Allen to reconsider "a very serious blot" in the legislation: "the power it gives to every one of fourteen hundred or fifteen hundred police-men to 'run in' people without a warrant." Newman opined that this was "too serious a power to place in the hands of every policeman." ${ }^{648}$ The next speaker, Liberal Member Poole, after stating his opposition to Newman's attitude towards religious objectors to service, offered his support

\footnotetext{
${ }^{646}$ NZPD 1914, vol.171, p.388.

647 New Zealand Gazette, 10 November 1914, p.4022.

${ }^{648}$ NZPD 1916, vol.175, p.720.
} 
for the same Member's criticism of the arrest-without-warrant clause: "It is a mistake to grant to any policeman, no matter how tactful he may be, no matter how courteous he may be, the right to arrest an individual on sight." 649 Moments later, Webb agreed that this power would lead to innocent men being "arrested on the street and put into gaol without the slightest justification." Webb stated that he and other labour leaders had opposed this power as they "thought that power altogether too great, and that there was every likelihood of its being abused." 650

None of these Members stated that their opposition to the police's power to arrest without warrant was restricted to matters arising from conscription: it was a general opposition to the power itself. The fact that this power already existed in other legislation allowed Joseph Ward to make a simple counter-argument: "Why, any one in this House listening to the honourable members when they talk about the frightful crime the Government is committing in imposing upon the country a Bill which gives power to have a man arrested without warrant would imagine, as every one of those members not only implied but suggested, that that power was something unheard-of." Ward pointed to section 65 of the Police Offences Act, giving a constable the power to take into custody, without warrant, "All loose, idle, and disorderly persons whom he finds disturbing the public peace, or any person whom he has good cause to suspect of having committed or being about to commit any crime or breach of the peace." Ward argued that he had "never heard any member opposing that Act" and that its provisions had "been put into operation time and again in this country." He went on to claim that it was essential to give police the same power under the Military Service Act, in order to deal "with those who refuse to give information about themselves or to do their duty, and who expect their fellow-citizens to do all the fighting for them and preserve their families and all that is dearest to them in this country." 651

In the Legislative Council, Bell referred to Ward's argument, taking it even further by stating that the power of arrest-without-warrant was so "far from that being without precedent" that there was "no part of our legislation, both in criminal and revenue matters, which does not contain some provision of that kind." Bell pointed to the ability of customs officers and

\footnotetext{
${ }^{649}$ NZPD 1916, vol.175, p.724.

650 NZPD 1916, vol.175, p.734.

${ }^{651}$ NZPD 1916, vol.175, p.739.
} 
policemen, under the Customs Act, to bring any person before a Justice if they suspected that person of evading customs, and were not satisfied with the answers such a person gave to their inquiries; consequently, he argued that to say the powers given to police under the Military Service Act were "anything novel, anything contrary to the common course of English justice" was "wholly erroneous". Bell also argued that opposition to the clause was really just a result of its wording: such opposition "would never have arisen if instead of the words 'arrest without warrant' the words used had been 'detain and bring before a Justice.'" He believed the two expressions meant "exactly the same thing. The expression in the Customs Act is 'detain and take before a Justice,' and in the Crimes Act and Police Offences Act the words are 'arrest without warrant'". His Government would "not accept an amendment which would so far weaken the Bill as to allow a shirker to tell the police to go to a Justice and summon him, and in the meantime to depart from the neighbourhood." He also dismissed the idea that giving police the power to arrest-without-warrant was a threat to liberty, given the behaviour of the New Zealand Police up to that point:

The liberty of the subject is said to be at stake when a constable can arrest without warrant a person he suspects of being a person evading the law. How many people do you suppose are arrested without warrant by the police - apart from the active criminal class - in the course of the year? Practically there are none. How many are arrested by the revenue officials? An occasional person on the wharf. How many innocent people have been condemned to prison under those circumstances or hauled before Justices to answer for their offences? None - at all events, none to my knowledge. The necessity for making the Act express that which Parliament means, and effecting that which Parliament intends, is the necessity for such a provision. To omit some such provision, word it how you please, is to leave it in the power of individuals to practically defy the law, and, worse, to make it ridiculous by evasion." 652

Another Member of the Legislative Council, Earnshaw, stated that he had "no time for our policemen", that he had detested them "ever since boyhood" - yet he felt it was "no hardship upon any man in this country to at once say to any policeman that approaches him, 'My age is so-and-so; I work at such-and-such a trade,' and give him the required ${ }^{652}$ NZPD 1916, vol.175, p.875-6. 
information." Earnshaw stated that the world was living in "martial times", and that although New Zealanders were living under "civil law" - that it was "a grand thing" that they were able to do so "after so long a period since the outbreak of war" - this very continuation of civil law "ought to be an argument why every man in this country should give every evidence he can to the authorities to assist in the working of the measure". ${ }^{653}$

During the committee stages of the Bill, Liberal Member Thomas Mason Wilford moved to remove the police power to arrest without warrant those who failed to answer questions regarding their enrolment in the Reserve; his amendment was defeated by 37 votes to 24. ${ }^{654}$ However, Bell's advice about the choice of wording was incorporated in the final Act: in place of the original "any man reasonably suspected of any such offence may be arrested without warrant by any constable", Parliament settled on "any man reasonably suspected of any such offence may be detained by any constable and brought before a Justice of the Peace to be dealt with according to law." 655 The effect was the same, but the phrasing was considered less controversial.

This debate sheds a great deal of light on the way parliament dealt with the expansion of police and state powers during the war. Traditionally, police required warrants to enter property and conduct searches, and to arrest people for specific crimes, but not in order to make arrests in public with the intention of keeping the peace. The War Regulation expanding the power to arrest-without-warrant effectively expanded the definition of a breach of the peace to include a breach of the military effort, while the Military Service Act went further in including unsatisfactory answers to war-related questioning. Ultimately, however, opposition to the powers contained in the latter Act was presented as opposition to the power to arrest-without-warrant in general; the presentation was uninformed, and reflected politicians' attempts to construct arguments against legislation which was already controversial for other reasons - or, in Newman's case, an attempt to make sure the legislation did not become more controversial than it had to be (in the event, he voted against removing the power to arrest-without-warrant). Powers which were uncontroversial in the War Regulations, which had been passed in the first rush of enthusiasm, became

\footnotetext{
653 NZPD 1916, vol.176, p.5.

654 Plus one pair; NZPD 1916, vol. 175, p.698-9.

655 Ibid; Military Service Act 1916, s44 (2).
} 
controversial once they were used to enforce conscription rather than merely loyalty to the cause. Similarly, lack of opposition to changes to the laws of evidence does not prove that these changes were insignificant, but that politicians were only willing to oppose increased police or judicial powers when these powers were part of legislation which was already controversial for other reasons.

\section{Persecuting the Enemy Within}

The group most obviously affected by the suspension of the checks and balances on executive power were those who represented the enemy: aliens from enemy nations. At the beginning of the conflict, the Government immediately moved to restrict the freedoms of unnaturalized subjects of Germany and Austria-Hungary, while accepting those who had taken British naturalization as ordinary citizens, although as the war progressed, public outcry pressured the government to revoke their naturalization and classify both groups as enemy aliens.

Within the first week of the war, police began arresting non-naturalized enemy aliens, many of whom were interned on Somes Island. ${ }^{656}$ Among the arrestees were members of the German Army Reserve, who presented a legitimate concern to Imperial security. Although arrested by the civil police, internees were imprisoned under military authority, the first instance of police acting under military jurisdiction to service the war effort. By 1919, of the six-thousand-plus New Zealand residents born in Germany or Austria-Hungary, around 450 had been interned on one of the prison islands: most were kept on Somes, while highstatus prisoners went to Motuihi ${ }^{657}$

While the first arrests were of non-naturalized enemy aliens, any German or AustroHungarian citizens who wished to show their loyalty to their adopted country were prevented from doing so when the New Zealand Government suspended naturalization of

656 Dominion, 11 August 1914, p.6; besides Somes Island, enemy aliens were also confined in Motuihi Island, Auckland; Ripapa Island, Canterbury; and Devonport Barracks in Auckland: Andrew Francis, 'To Be Truly British We Must Be Anti-German': New Zealand, Enemy Aliens and the Great War Experience, 1914-1919 (Bern: Peter Lang, 2012), p.69, 113. Francis provides more definite figures for the number arrests and interned on Somes island in the first days of the war - 90 internees, including 56 reservists - but the Dominion article he cites lists only 63 plus "about half a dozen" arrestees, of whom 30 and the half-dozen are specifically noted as reservists. ${ }^{657}$ AJHR 1919, H-33, p.2. As Andrew Francis notes, exact figures are difficult to ascertain: Francis, p.113. 
enemy aliens for the duration of the war. ${ }^{658}$ This suspension did not reflect the policy of Great Britain, where 146 Germans and forty-four Austro-Hungarians naturalized during the war. ${ }^{659}$ In November 1914 the Government extended its definition of enemy aliens to include those who were naturalized in New Zealand rather than Britain. ${ }^{660}$ The November regulations, made under the War Regulations Act, also extended the definition of "enemy alien" to encompass "any person reasonably suspected of being" such, and under the parent statute, "the burden of proving that the accused" was "not an alien" was laid upon the accused. ${ }^{661}$ The same Act differentiated between aliens - whether from enemy nations or not - and British citizens in the maximum punishments set for breaching war regulations: three months for Britons, twelve for aliens. ${ }^{662}$ However, an amendment in October 1915 extended the maximum twelve-months' penalty to British citizens, in order to comply with an Imperial Government request. ${ }^{663}$

Andrew Francis has recently argued that Massey was "determined to execute a liberally tolerant policy" towards enemy aliens, and that his main motivation was simply to follow to the letter the instructions of the Imperial Government. ${ }^{664}$ Responding to demands for tighter restrictions on such aliens, Massey noted his advice from London not to punish anyone "whose known character precludes suspicion, or who are personally vouched for to the satisfaction of the Government." 665 Such characters included Professor von Zedlitz, a personal acquaintance of Alexander Herdman: during the first year of the war, the Cabinet repeatedly resisted pressure from rampantly anti-German Members of Parliament, most notably John Payne, to arrest the Professor, before finally bowing to public pressure, a fact noted by von Zedlitz himself. ${ }^{666}$ Police similarly found themselves under pressure to persecute suspected German spies, spending countless man-hours following up reports

\footnotetext{
${ }^{658}$ NZPD 1914, vol.169, p.502, 527; vol.171, p.139-41.

${ }^{659}$ Francis, p.74.

660 NZ Gazette, 10 November 1914, p.4022. This reflected the fact that even before the war, those who received British naturalization in a British territory outside of the Home Country were only considered British citizens in the territory in which their naturalization was processed.

661 War Regulations Act 1914, s6 (b.).

${ }^{662}$ War Regulations Act 1914, s4.

${ }^{663}$ War Regulations Amendment Act (No. 2) 1915, s12. The request for this amendment stemmed from the fact that only those who had committed offences punishable by a term of imprisonment of at least twelve months could be extradited under the Fugitive Offenders Act: NZPD 1915, vol.174, p.675.

${ }^{664}$ Francis, p.8.

665 NZPD 1915, vol.173, p.121.

${ }^{666}$ George von Zedlitz, The Search for a Country: The Autobiography of G.W. von Zedlitz (Plymouth: Paul's Book Arcade, 1963), p.17-8; see Education Chapter for more detailed discussion of von Zedlitz' case.
} 
from members of the public which Commissioner O'Donovan lamented were usually little more than "will-o-wisps". 667 The Government's attempts to be fair to enemy aliens stand in marked contrast to their treatment of conscientious objectors, trade unions and those Iwi who did not volunteer to serve, particularly given that unlike these groups, Germans and Austro-Hungarians were nominally the enemy against whom the war was effort was supposed to be directed.

Yet it would be wrong to present the plight of enemy aliens in wartime New Zealand as generally benign. Under the regulations of November 1914, any enemy alien either unnaturalized or naturalized in New Zealand could be arrested and detained "in such place and manner" as anyone appointed a "military authority" by the Minister of Defence "thinks fit and during his pleasure". ${ }^{668}$ This regulation essentially put all enemy aliens under a military law with next to nothing in the way of checks and balances. An Act of September 1917 stated that, whenever the Governor-General in Council considered it "expedient", he could revoke the citizenship of any naturalized British subject, whether naturalized in Britain or New Zealand, whether alien, ally or neutral. ${ }^{669}$ Another Act of the same month required all non-naturalized aliens to register with the police within 28 days, providing their name, nationality, address, occupation, place and date of birth, details of their arrival and residency in New Zealand, and a list of their immediate family members. They were also required to register any changes in their place of abode within two weeks. ${ }^{670}$ This registration provided a significant expansion of the state information apparatus, as well as its surveillance of personal movements; this surveillance was directed at all foreign nationals regardless of whether anyone considered them a threat - and the burden of proving one was not an alien lay on the accused. ${ }^{671} \mathrm{~A}$ month later, the Government declared forfeit all land purchased by enemy aliens since the start of the war, and deprived all enemy aliens of their right to vote; even non-enemy aliens were prohibited from standing in local body

\footnotetext{
667 "Signalling, Karori” (NA: Box: 10/t, Item ID: R21371956); Steven Loveridge, "Sentimental Equipment: New Zealand, the Great War and Cultural Mobilisation," (PhD Thesis: Victoria Univeristy of Wellington, 2013), p.114; Richard Hill, "State Servants and Social Beings: The Role of the New Zealand Police Force in the First World War," forthcoming chapter, p.5.

668 New Zealand Gazette, 10 November 1914, p.4022.

669 Revocation of Naturalization Act 1917, s3.

670 Registration of Aliens Act 1917, s5, s10.

${ }^{671}$ War Regulations Act 1914, s6.
} 
elections. ${ }^{672}$ The prohibition on enemy aliens purchasing land was extended once the war came to an end. ${ }^{673}$

Even enemy aliens considered not to be a threat to the realm were deprived of their civil liberties, their right to engage in the democratic process, and the sanctity of their private property; all such rights were often invoked as evidence of British liberty as opposed to Germanic despotism, but the conflict between these two supposed historical forces meant the restriction of British liberties to the British. Although British men with German or Austrian parentage were accepted into the Expeditionary Force, after the desertion of one such recruit in July 1916, men of "German extraction" were withdrawn from frontline duty. This response was poorly implemented: men were not initially told why they were being withdrawn, and resented the aspersions cast on their loyalty once they found out. At least one committed suicide. ${ }^{674}$

At home, enemy aliens whose good character was not vouched for by loyal Britons faced physical incarceration. In many ways, eking out the war on an island in Wellington or Auckland harbour was not an unpleasant way to spend the time: the high-class prisoners of Motuihi were free to roam the island and allowed shopping visits to the city. ${ }^{675}$ Even the lower-classes on Somes were able to make use of island's prime fishing location. ${ }^{676}$

Yet this mask of pacific idyll hid a darker reality. Allegations of cruelty at the hands of prison commandant Major Dugald Matheson were presented to the visiting American and Swiss consuls by the inmates of Somes Island, and forced a government inquiry in the last year of the war. Inmates alleged that Matheson "administered ill treatment for its own sake [..] for the mere love of indulging in such conduct." After hearing 113 witnesses, the inquiry head, Supreme Court Judge Frederick R Chapman, concluded that Matheson lacked "the malevolent character implied" by the allegations, most of which he felt were exaggerated. ${ }^{677}$ Matheson did "everything within his power" to "preserve the health,

\footnotetext{
672 War Legislation Act 1917, s3, s12.

${ }^{673}$ War Legislation and Statute Law Amendment Act 1918, s6.

${ }^{674}$ Christopher Pugsley, On the Fringe of Hell: New Zealanders and Military Discipline in the First World War (Auckland: Hodder and Stoughton, 1991), p.83-4; Jock Vennell, The Forgotten General: New Zealand's World War I Commander Major General Sir Andrew Russell (Sydney: Allen and Unwin, 2011), p.116.

675 Francis, p.125.

${ }^{676}$ AJHR 1919, H-33, p.2.

677 AJHR 1919, H-33, p.4.
} 
comfort, and well-being of the men committed to his charge", including securing "a more liberal scale" of rations. ${ }^{678}$ Essentially, Chapman brushed off a large number of complaints as arising from "disciplinary measures" necessitated by the misbehaviour of the complainants, even though complainants included one who was assaulted by six guards while in handcuffs. ${ }^{679}$ The twenty-seven pages of Chapman's report list case after case of men alleging mistreatment, and Chapman responding that he had no reason to believe their allegations, that they were being punished for breaches of discipline - and that anyway, the discipline worked. 680 The Government began the war by establishing, by way of emergency legislation, the doctrine that the right to silence, the right to innocence in the absence of guilt, and the laws of evidence were inapplicable when the Crown was faced with crisis; at war's end, Justice Chapman (whose youngest son died in the war) confirmed that enemies of the Crown could not be considered reliable witnesses:

In the cases of alleged ill treatment I have had to investigate a very old story, and in some cases have found myself forced to disregard direct evidence because I found myself unable to believe that the treatment has been truly represented. ${ }^{681}$

\section{Regulating Manpower I: Conscripting the Troops}

While the surveillance and incarceration of enemy aliens was driven to a great extent by popular demands for persecution, it began with the Government's desire to ensure the defence of the realm. Ultimately, many of the same methods used to regulate the enemy were extended to the defenders themselves, particularly after the introduction of conscription. Enemy aliens were prohibited from departing New Zealand's shores from August 1914; the same prohibition was extended fifteen months later to every male "over the age of eighteen years" without a permit issued by the Minister of Internal Affairs (or his

\footnotetext{
${ }^{678}$ AJHR 1919, H-33, p.5.

${ }^{679}$ David McGill, Island of Secrets: Matiu/Somes Island in Wellington Harbour (Wellington: Steele Roberts and Silver Owl Press, 2001), p.48.

${ }^{680}$ For example, description of Hugo Steinbrügger, AJHR 1919, H-33, p.9.

${ }^{681}$ AJHR 1919, H-33, p.26; Peter Spiller, “Chapman, Frederick Revans," in Dictionary of New Zealand Biography, updated 30 October 2012, URL: http://www.TeAra.govt.nz/en/biographies/3c10/chapman-frederick -revans
} 
Under Secretary). ${ }^{682}$ The National Registration Act, which required all male residents between the ages of seventeen and sixty to register themselves and provide a raft of personal details to the Government Statistician, in fact pre-dated the Registration of Aliens Act by almost two years.

The permit system introduced at the end of 1915 brought a thorough passport system to New Zealand for the first time: prior to the war, British subjects without criminal records had been nominally free to move throughout the Empire unencumbered by official observation. ${ }^{683}$ The National Registration introduced at the same time meant that all male New Zealanders were both confined and classified, extending the reach of the state, not merely in size - although enforcing the Registration Act was a sizeable undertaking - but in intimacy. The imposition of all-encompassing male registration coincided with the extension of income tax discussed previously in this thesis: recruiting and revenue gathering would both now require all men to keep the State informed of their professional and (to a lesser degree) personal lives in ways not expected in peacetime. National Registration required every man to furnish the Government Statistician with his name, date and place of birth, address, "nationality and country of allegiance", marital status, details of any dependants, details of his occupation and prior military experience, and a thorough report on his physical health. Those aged between nineteen and forty-five also had to state whether they had volunteered for military service - and if not, why not. ${ }^{684}$ Under the subsequent conscription system, any "natural-born British subject" of military age who failed to inform the authorities of their movements could be subject to a "fairly heavy penalty" of up to twenty pounds; changing their name without the consent of the Minister of Internal Affairs could attract an even heavier fine, or three months in prison. ${ }^{685}$ Tabulating the 303,704 responses to Registration was the most significant expansion of the State's knowledge-gathering apparatus at the time, but the State's ability to implement registration was limited, and

\footnotetext{
682 NZ Gazette, 15 November 1915, p.3813.

683 In practice, the Imperial and Dominion governments did restrict migration on the basis of race - Radhika Viyas Mongia, "Race, Nationality, Mobility: A History of the Passport," Public Culture 11 (3), p.548, 552-3. 684 National Registration Act 1915, s4; New Zealand Gazette, 21 October 1915, p.3550-1.

685 Military Service Act 1916, s42-3; NZPD 1916, vol.175, p.487.
} 
after more than two years the Statistician estimated up to 5,000 men had evaded his gaze. ${ }^{686}$

The Prime Minister claimed that National Registration was not intended to facilitate conscription: he was "a believer in compulsory national training", which had been in place for over five years, but not "in compulsory service or conscription". ${ }^{687}$ But it was "absolutely necessary" to "ascertain what resources" New Zealand possessed in order to meet its recruitment obligations, which had grown - from the initial Expeditionary Force of less than 8,000 men - to a full Division of some 20,000 men (plus 1800 Mounted Rifles) from March 1916, requiring two or three thousand reinforcements every month. ${ }^{688}$ Increases in both the size of the Force and the rate of reinforcements, coupled with the fact that, by 1916, the most eager volunteers had all sailed, put the voluneer system in a precarious position. By Christmas of 1915, just weeks after the Government compiled and released the results of Registration, the number of men entering Trentham Military Camp fell behind the number of troops required. ${ }^{689}$

The two controversial aspects of National Registration were the lack of a contemporaneous "survey or wealth" (discussed in chapter one) and the demand that men aged nineteen to forty-five explain whether they are willing to serve, and if not, to provide their reasoning. The rabidly anti-German Labour MP John Payne stated his absolute support for registering the manpower resources available, but was averse to requiring men to lay bare their personal reasons for or against service. ${ }^{690}$ Massey defended this inquiry as the means to "prove to the country that compulsory service is not necessary." ${ }^{691}$ However, of the 193,341 men of military age who responded as to whether they would be willing to serve, eightythousand were unwilling to serve overseas, and thirty-five-thousand were not willing to serve even in a "civil capacity"; of the latter, 8,821 were single men with no dependents and, in the eyes of the public, had no excuse for "shirking" service. ${ }^{692}$ In his groundbreaking

\footnotetext{
${ }^{686}$ Paul Baker, King and Country Call: New Zealanders, Conscription and the Great War (Auckland: Auckland University Press, 1988), p.208.

687 NZPD 1915, vol.174, p.129.

${ }^{688}$ NZPD 1915, vol.174, p.124; 1916, vol.175, p.485; Pugsley, On the Fringe of Hell, p.52-3, 214, 218.

689 Baker, p.45.

${ }^{690}$ NZPD 1915, vol.174, p.133.

691 NZPD 1915, vol.174, p.977.

${ }^{692}$ AJHR 1916, H-35, p.3. These figures are slightly higher than those quoted by Paul Baker, although we have taken them from the same source; Christopher Pugsley took his figures from Baker, and introduced a further
} 
study of conscription, Paul Baker established that public rancour against such "shirkers", and the consequent the demand for "equality of sacrifice", was what pushed the country to accept conscription, rather than some sort of plot from the centre; Baker's thesis has thus far stood up to a quarter-century of further research on the topic. ${ }^{693}$ Nevertheless, while the Military Service Act made conscription legally permissible from the $1^{\text {st }}$ of August 1916, the Government resisted taking the initial ballot for another two-and-a-half months, when the number of volunteers fell so far behind the rate of reinforcements required that the Government risked shirking its own commitments. ${ }^{694}$ The Act divided New Zealand's reserve of military-age men into two groups. The first consisted of men who were unmarried; widowers (and men separated from their wives) without children under sixteen; and men who had married during the war (and who were thus suspected of having married to shirk their Imperial responsibilities). The "Second Division" consisted of all others - men who were married, or who supported children from a previous marriage. ${ }^{695}$ While the Act initially allowed volunteering to continue, the "First Division" were called up by ballot once recruiting slowed, with the Second to follow only once the First were exhausted.

Introducing the Military Service Act, James Allen said that conscription could still be avoided, if "the local bodies who were invited to assist the Government" in encouraging recruiting had done their part. ${ }^{696}$ The lengths to which the he and Massey went to demonstrate that they were only bringing in conscription after having exhausted all other options - that they were, in effect, compelled to compel - were rather facetious, given that mere minutes later Allen argued that the most "democratic" way to "win the war would have been compulsory national service right from the start", and that in private he was writing to General Russell that he had "held right from the start that compulsion was the fairest way by which to secure the soldiers we wanted," that "it would have paid this country if the whole of the labour and brains of this country had been organised right from

error, assigning Baker's figure for those willing to serve overseas to those willing to serve in a civil capacity: Baker, p.58; Pugsley, On the Fringe of Hell, p.224.

${ }^{693}$ Baker, p.46; Steven Loveridge, "Soldiers and Shirkers: Modernity and New Zealand Masculinity During the Great War," New Zealand Journal of History 47, 1 (2013), p.70. It is worth noting that neither Baker nor subsequent historians who have accepted, at least in part, his thesis (among whom I include myself), have conflated the popularity of conscription with a justification for conscription.

${ }^{694}$ Baker, p.95.

${ }^{695}$ Military Service Act 1916, s4.

${ }^{696}$ NZPD 1916, vol.175, p.485. 
the start." ${ }^{697}$ Massey described himself as "a supporter of national service" not because he loved it, but because he believed it "to be necessary": so long as the enemy relied upon organisation, it was "folly for Britain to go on depending on her Navy and her voluntary system." ${ }^{698}$ While concluding the final House debate, Allen even claimed the intention of the Act was not to impose conscription, but "to induce volunteering." 699

While Massey and Allen based their argument for compulsion upon the necessity of securing a reliable flow of recruits, the dominant theme of the first House debate on the bill was that conscription was justified by its fairness, by "equality of sacrifice." Reform members stated that "drastic action" was needed to make shirkers "do their duty"; that from "one end of New Zealand to the other" there was "a feeling" that some people were not "willing to do their duty" whilst others died; and that "the so-called voluntary system" brought " inequality of sacrifice". ${ }^{700}$ Their Liberal counterparts similarly argued that the voluntary system was "not working equitably or fairly"; was "not a fair system"; had "not resulted in equality of sacrifice"; that they had been forced to conscript due to "the unfairness of the voluntary system", its "great deal of inequality". ${ }^{701}$ Albert Glover, the Liberal Member for Auckland Central, stated that he was not prepared to use the word "shirker", owing to "the frailty of human nature", but that he believed the "burden of Empire" demanded "equality of sacrifice." 702 George Russell, the Minister of Internal Affairs, criticised Labour members for failing "to see the inequality of a method by which one man goes and offers his services for the Empire while another man equally entitled to fight stops away in order to reap the benefit of what the other man is going to do." 703

Some Liberal members gave this argument from inequality of sacrifice a particular left-wing spin. Dunedin South Member Thomas Sidey believed "a very large number of the workers of this country" supported conscription "because of the unfairness" of voluntarism; Timaru Member James Craigie said that "the unequal sacrifice" had seen a disproportionately high

\footnotetext{
${ }^{697}$ NZPD 1916, vol.175, p.486; Allen to Russell, 7 November 1916.

698 NZPD 1916, vol.175, p.619.

${ }^{699}$ NZPD 1916, vol.175, p.785.

700 NZPD 1916, vol.175: David Buick, MHR for Palmerston, p.628; Dr. A. K. Newman, MHR for Wellington East, p.499; T. A. H. Field, MHR for Nelson, p.563.

${ }^{701}$ NZPD 1916, vol.175: George Forbes, MHR for Hurunui, p.607; William Dickie, MHR for Selwyn, p.593; T. W. Rhodes, MHR for Thames, p.587; T. M. Wilford, MHR for Hutt, p.491; John Anstey, MHR for Waitaki, p.570. 702 NZPD 1916, vol.175, p.602-3.

${ }^{703}$ NZPD 1916, vol.175, p.626.
} 
number of wage-earning workers sent to the front; and their Wairarapa colleague John Hornsby praised "the fairness and rightness of a compulsory measure" which would "enable the State to say" to "the sons of rich fathers" who were "driving about in their motor-cars" that they had "no right to stay here" while the men working their farms were going. ${ }^{704}$ Independent Labour Member John Payne also chastised the "wealthy people's sons" who were "shirking their duty whilst sons of workers" were "going forward to the war." 705 After hearing these sentiments, Allen agreed that "every labouring-man ought to advocate" conscription on the grounds of "equality of sacrifice." 706

At its most ridiculous, this argument based on fairness could be used by men who remained at home to argue that they would not enlist until the "shirkers" did, enabling a sort of eternal-regression of men pointing to one-another's shirking as their excuse. Even this argument received a serious airing by two Reform speakers: Member for Motueka Richard Hudson noted the men who claimed they were "quite prepared to go to the front" but who did "not see why they should go while So-and-so" was "allowed to shirk"; W.H. Field, the Member for Otaki, refused to believe that there were "many shirkers" in New Zealand, but nevertheless accepted that many had "refrained" from going because service had "not been made universal", and that all were "not treated alike." 707 Neither member offered an explanation of why such men did not constitute genuine "shirkers", while others did.

At its most extreme, the argument from fairness became an argument from eugenics: Sidey claimed that "all modern war" was "contrary to eugenics", but that this degenerative effect could be reduced by compulsion. ${ }^{708}$ Leonard Isitt, the Liberal Member for Christchurch North, believed the voluntary system - or "moral conscription" - left "the shirker and the crank and the blatherskite to perpetuate the race." 709 Three Reform Members also based support for conscription on eugenics: Edward Newman (Rangitikei) said the country had "been denuded of the better class of men"; Alexander Harris (Waitemata) argued that under the volunteer system, they were "sending the flower of the nation away" while "the worst elements of the community" remained behind to "become the fathers of the future citizens

\footnotetext{
${ }^{704}$ NZPD 1916, vol.175, p.509, 531-2, 597.

${ }^{705}$ NZPD 1916, vol.175, p.573.

${ }^{706}$ NZPD 1916, vol.175, p.644.

${ }_{707}$ NZPD 1916, vol.175, p.545, 633.

${ }^{708}$ NZPD 1916, vol.175, p.510.

${ }^{709}$ NZPD 1916, vol.175, p.538.
} 
of New Zealand", which could only mean "the permanent deterioration of the race". ${ }^{710}$ Waikato Member James Young quoted President Lincoln to the effect that volunteering "ground up the choicest seed corn of the nation" while "leaving the cowards, shirks, egotists, and money-makers to stay at home and procreate their kind." 711

Against the argument that only conscription was fair and that allowing recruitment to progress by volunteering alone was degenerative, several Liberal members argued that had soldiers been provided with adequate wages and support for dependants, conscription would never have been contemplated. George Witty of Riccarton said that "if sufficient inducement had been offered from the first", Parliament would have required no "scrap of paper" to compel men to enlist; there was "no equality of sacrifice" in the conscription plan, as soldiers would be forced to fight for a pittance while "well-to-do" men were allowed to remain at home and reap the rewards. ${ }^{712}$ Charles Poole, from Auckland West, felt that measures to address the cost of living and implement "a fair and equitable system of taxation" should have "preceded this national-service Bill." ${ }^{13}$ C. J. Talbot, Member for Temuka, claimed that the "pay of married soldiers with children" was "not sufficient", and that the House should have been told "something about the proposals of the Government, financial and otherwise, before this Bill was brought down". ${ }^{714}$ Albert Glover, from Auckland Central, argued that "if the Government had done more for the returned wounded soldiers they would have proved the best recruiting agents in our Dominion" - but some had note even received their back-pay. ${ }^{715}$ This argument even found support from two Reform Members : Richard Hudson of Motueka agreed the country was "not doing its duty" to soldiers given inadequate pensions, and inadequate support for their dependents; while giving conscription his "whole-hearted support", James Young of Waikato criticised New Zealand for failing to provide as much financial assistance to her troops as Great Britain provided to hers. ${ }^{716}$

\footnotetext{
${ }^{710}$ NZPD 1916, vol.175, p.561, 524.

${ }^{711}$ NZPD 1916, vol.175, p.639.

712 NZPD 1916, vol.175, p.492-5.

${ }^{713}$ NZPD 1916, vol.175, p.497.

${ }^{714}$ NZPD 1916, vol.175, p.522.

${ }_{715}$ NZPD 1916, vol.175, p.603.

${ }^{716}$ NZPD 1916, vol.175, p.547, 641.
} 
In spite of their reservations, all six of these men voted for conscription; their argument was advanced with more vigour by the Labour members who voted against it. Dunedin North Member Andrew Walker said there was no necessity for conscription while volunteers were "coming forward in great numbers", and that others would be enabled to come forward if adequate provision were made for their dependents. ${ }^{717}$ Grey Member Paddy Webb argued that had "the suggestions of the Labour members and several of the Radical members of this House been given effect to - namely, to pay better wages for the men in the trenches, and to improve upon the pensions scheme so that any man who goes and comes back maimed is provided for by the State for the rest of his life" there would then "have been no need for this Bill." 718 Later in the same debate he returned to this point, insisting that it would be "unfair of this House to pass this Bill to take men away from their responsibilities without first of all making adequate recompense". ${ }^{719}$

Referring to the outbreaks of disease at Trentham Military Camp, John Payne claimed that the "soldiers were bled, with the connivance of the Minister of Defence", and that it was as a result of such behaviour that Parliament ended up contemplating the Bill in question, and that there was "no equity about this conscription system."720 He later claimed to have "incontrovertible evidence that men who had enlisted - married men with families" had been forced "to rely upon a private charity in order to be able to carry on their homes." The objective of the Bill, claimed Payne, was "not to get soldiers, but to get cheap soldiers", soldiers who would "involve the State in the least liability". ${ }^{721}$ Instead of forcing all single men to serve, these Members argued that financial provision should first be made to enable those with dependents to volunteer.

Henry Thacker, Liberal Member for Christchurch East, took this argument to its extreme, alleging that the Minister of Defence had forced the country into a "crude conscription of blood" by "slowly and surely" overpledging its commitment, and by refusing to fix problems associated with the health of recruits and the state of the camps, which were preventing men from serving; conscription was being introduced, not from real need, but from Allen's

\footnotetext{
717 NZPD 1916, vol.175, p.551-2.

${ }^{718}$ NZPD 1916, vol.175, p.503.

719 NZPD 1916, vol.175, p.567.

${ }^{720}$ NZPD 1916, vol.175, p.515.

${ }^{721}$ NZPD 1916, vol.175, p.573, 577.
} 
desire for "a military regime" that would "put the country under the Defence Minister under one guise or other." 722

A number of conscription supporters attempted to rebut claims that compulsion was a means to avoid paying adequate wages. Speaking of the married men who supposedly had to remain at home due to lack of support for their families, Sidey claimed he had "never heard of a reply to the effect that they would go if the State would make better provision for their dependents. The main reply was this: that they would come as soon as their turn came, when those who had less responsibilities than they had gone."723 His Liberal colleague from Napier, John Vigor Brown, facetiously offered the view that none of "our men" who had "gone to the front" looked "to the money they will receive", but were "quite satisfied" to "fight for the freedom of the British Empire." 724 Edward Newman, the Reform Member for Rangitikei, even claimed that New Zealand had "endeavoured to do our duty to the men" and that more was "being done for our soldiers than ever was done in any other part of the British Empire on any previous occasion in connection with any war." 725

When the Prime Minister spoke, he was interrupted by another insistence that higher pay for soldiers would make conscription unnecessary. Massey first stated that he was "not going to deal" with this argument, though he could offer no better reason than the fact that it had been "repeated ad nauseam" (which, surely, would be a reason to deal with it); following a second interjected demand that he answer the argument, he simply said that the "workers are not mercenaries", again avoiding the issue. ${ }^{726}$ Wrapping up the debate, Allen responded to Payne's claim about cheap soldiers by reassuring the House that there was "no intention" to "make the soldier any cheaper" than they were already - which, again, failed to address the argument that they were already underpaid, and that the Government was trying to avoid raising their remuneration. ${ }^{727}$ After having to sit through such replies, Payne accused the side of the House which represented "the money-bags of this country" of using the term "mercenary" to "gag" their opponents, in order to "shirk their

\footnotetext{
722 NZPD 1916, vol.175, p.500-2.

${ }^{723}$ NZPD 1916, vol.175, p.509.

${ }^{724}$ NZPD 1916, vol.175, p.558.

725 NZPD 1916, vol.175, p.562.

${ }^{726}$ NZPD 1916, vol.175, p.617.

${ }^{727}$ NZPD 1916, vol.175, p.642.
} 
responsibilities". ${ }^{728}$ In the Legislative Council, William Hall-Jones responded to claims that introducing "the money question" demonstrated "a mercenary motive" with the cry of "Buncombe!" and said that the real mercenary motives were held by those "coining money during this war". ${ }^{729}$ Regardless of whether one agrees with Payne and others that conscription was a ruse to underpay soldiers, the empty dismissal which was offered as the only response to their argument is quite stunning. Massey and Allen had made up their minds that conscription was necessary, and were not willing to take other options seriously, whatever they said to the contrary.

More surprising than their unwillingness to consider other options was their lack of reference to Great Britain's Military Service Act, which passed into law in January and came into effect on 2 March, just under three months before the first conscription debate in New Zealand's House of Representatives. Allen left his listeners in no doubt that conscription was intended solely to facilitate the defence of the British Empire:
"In concluding, I desire to summarize very briefly the reasons why I think this Bill is necessary. It is necessary, in the first instance, in order that we may keep our promise to the Mother-land. It is the bit of paper which, when edited and confirmed by the members of this House and put upon the statute-book, gives the security for the fulfilment of the pledge we have given to the Imperial Government."730

Massey, similarly, stated that conscription was intended to enable "the Dominion of New Zealand to do its full duty to the Empire in the great struggle in which the Empire" was engaged. ${ }^{731}$ On the Liberal side of the House, John Hornsby voted for conscription because the Dominion would either have to keep its "word with the authorities of Britain" or "face everlasting disgrace not only in the eyes of Britain but" in its "own eyes - a very much deeper disgrace than to be despised by people outside". ${ }^{732}$ Hornsby's statement suggests that, while conscription was a means to facilitate New Zealand's duty to Empire, it was being introduced primarily due to local pressure. Allen's sole reference to the British Act was a

\footnotetext{
728 NZPD 1916, vol.175, p.574.

${ }^{729}$ NZPD 1916, vol.175, p.894.

730 NZPD 1916, vol.175, p.490-1.

731 NZPD 1916, vol.175, p.616.

732 NZPD 1916, vol.175, p.597.
} 
critical remark to the effect that it had "been proved from experience in Britain that the exempting" of men from service "by classes was a mistake" (though arguably the classification of the First and Second Divisions did just that). ${ }^{733}$ In contrast, this sole reference to the British Act in his speech in Hansard is followed by two pages of discussion of the Union draft from the American Civil War. Allen described how the change from a voluntary to compulsory recruiting system in America "was made among an Anglo-Saxon people, equally with ourselves sticklers for the law and the testimony, and at least as strongly tainted with a belief in the sacredness of the right of the individual to do what he pleases in season and out of season." He proposed that the success of the American draft should be taken as a "guide" for New Zealand. ${ }^{734}$ Massey, too, stated that the Military Service Act was "based on Lincoln's legislation at the time of the Civil War in America", although he concluded that New Zealand's scheme was "even more perfect than the American Act" because Lincoln's draft allowed rich men to buy exemptions by sending "substitutes", whereas New Zealand's aimed at attaining as much equality of sacrifice as was possible. ${ }^{735}$

One positive reference to the British Act came from the Liberal Member for Kaiapoi, David Buddo, who preferred the brevity of the British Act, as it left the details of exemptions up to Boards and Committees; Buddo was worried that section 17 of the New Zealand Act (giving Appeal Boards power to exempt men from service) allowed Members to "read into it what is not there" and created a fear that Boards could "exempt the rich man's son and send the poor man's son", thus failing to create the equality of sacrifice which justified conscription in the first place. ${ }^{736}$ Leonard Isitt also praised the British Act for including some exemption for men who objected to serving on religious grounds (for which no provision was made in the initial New Zealand Bill), although another Member objected that such provision was the "biggest blot" on the British Act. ${ }^{737}$

Two Reform Members followed Allen's lead in criticising the Britain's conscription scheme. Edward Newman argued that "England's unpreparedness" had "tempted Germany" to

\footnotetext{
733 NZPD 1916, vol.175, p.486.

734 NZPD 1916, vol.175, p.488.

735 NZPD 1916, vol.175, p.616.

736 NZPD 1916, vol.175, p.621.

${ }^{737}$ NZPD 1916, vol.175, p.541.
} 
initiate war, and that "now, after twenty months of strenuous effort at the front, England" had been "compelled to adopt a policy of compulsion." 738 William Nosworthy of Ashburton went so far as to say that New Zealand would have opted for conscription earlier, had it not been tied down by the need to follow the Imperial Government's lead:

\begin{abstract}
"we may be pardoned for not being the first to bring down such a measure. To a certain extent we had to be guided by legislation introduced by the Home Government in the matter of war, dealing a great national policy for the benefit of the Empire as a whole. I am of opinion that if the Imperial Government had introduced conscription for national service shortly after the war commenced, they would have given a lead to this Dominion as well as to the other overseas dominions; and no doubt we would all have taken a similar course."739
\end{abstract}

The fact that New Zealand's Military Service Act followed so hot on the heels of Britain's identically named legislation suggests that the Dominion's leaders were not willing to preempt their Home superiors, but does not prove that conscription was introduced for Imperial rather than local reasons. Certainly, domestic pressures ultimately stemmed from a desire to defend the Empire, but this massive expansion of State inference in the lives of men was only facilitated, not imposed, by Britain. Massey, Allen and their colleagues decided to compel men to fight for reasons of their own, not solely because of the decision of the British Government.

\title{
Regulating Manpower II: Policing the Troops
}

Once men were enrolled, either of their own volition or by compulsion, they were subject to the iron grip of military discipline. Although this is entirely unremarkable, what is curious is how New Zealand's troops faced discipline which was in some ways harsher than that imposed upon Australian or British recruits. General Andrew Russell, the Napier-born Commander of the New Zealand Division on the Western Front, was determined to mould

\footnotetext{
738 NZPD 1916, vol.175, p.569.

739 NZPD 1916, vol.175, p.604; see also p. 140-1. In opposition to following Great Britain's lead on conscription, Labour Member McCombs criticised "a disposition in New Zealand to follow slavishly everything that is done in England" - NZPD 1916, vol.175, p.225.
} 
his men into the most disciplined and effective fighting unit in the British Forces. To do so required swift punishment for indiscretions, and Russell was unhappy with "lenient" courtsmartial suspending the sentences of looters who were released back to their units to spread a negative influence. Under Russell, twenty-eight New Zealanders were sentenced to death by firing squad, although only five of these sentences were carried out. ${ }^{740} \mathrm{His}$ willingness to use execution to make an example of particular soldiers was "moderated by the experience and judgement" of Sir Douglas Haig's General Staff. ${ }^{741}$ Overturning one death sentence, British High Command showed up the "lack of knowledge of military law and procedure" among New Zealand officers. ${ }^{742}$

Unlike New Zealand troops, Australians were not subject to the death penalty: although Australian military commanders sentenced 121 of their men to execution during the First World War, under the Defence Act 1903 the Australian Government refused to allow such sentences to be carried out, this refusal stemming from mistrust of the shooting of their boys by British officers during the previous Anglo-Boer War. ${ }^{743}$ In contrast, New Zealand troops could be executed by order of both New Zealand and British authorities, and of the five New Zealanders shot by firing-squads during the war, one, the journalist Private John Braithwaite, was killed on British rather than New Zealand orders, and was one of only three soldiers in the British Forces executed for the crime of mutiny during the war. ${ }^{744}$

A New Zealand Supreme Court judgement sheds an interesting light on the Dominion's attitude to the position of our soldiers within the British military. In September 1916, a soldier in the New Zealand Expeditionary Force was served with a summons for "the alleged wrongful conversion of certain sheep." Owing to his absence, the Magistrate repeatedly granted adjournments until 6 December, when he decided to hear the case, overruling objections from the defendant's solicitor that section 144 of the Imperial Army Act 1881 exempted soldiers serving in "His Majesty's Regular Forces" from liability to be prosecuted in a Court of Law, except on specific charges (none of which related to sheep). Six days later, the Magistrate found for the plaintiff, and the soldier subsequently applied to the Supreme

\footnotetext{
740 Pugsley, On the Fringe of Hell, p.114; Vennell, p.112-4.

${ }^{741}$ Vennell, p.115; Chris Pugsley, "Russell, Andrew Hamilton," in Dictionary of New Zealand Biography, updated 30 October 2012, URL: http://www.TeAra.govt.nz/en/biographies/3r34/russell-andrew-hamilton

742 Pugsley, On the Fringe of Hell, p.113.

${ }^{743}$ Pugsley, On the Fringe of Hell, p.132-3, 145.

${ }^{744}$ Pugsley, On the Fringe of Hell, p.139-41.
} 
Court "for a writ of prohibition" to restrain the sheeps' owner from proceeding to recover the damages awarded. Finding against the soldier, Justice Edwards concluded that while the Imperial Army Act made members of the New Zealand Forces subject to "the disciplinary provisions of the Army Act", it did not make them part of "the Regular Forces of the Crown within the meaning of the Imperial Army Act". New Zealand troops were subject to all the disciplinary measures of the British Army, but not to the same legal protections afforded to British troops. ${ }^{745}$ As Chris Pugsley put it, New Zealand's "desire to be the best" at times "led to a disciplinary zeal that was tempered by British experience." However, when combined with the increasing administrational efficiency Russell developed, his harsh approach did achieve the end to which it was intended, and the New Zealand Division remained one of the best fighting units in the British Army right through to the end of the war, even as other units broke down from fatigue and a lack of reinforcements. ${ }^{746}$

\section{Regulating Manpower III: Punishing Objectors}

Just as New Zealand's soldiers could be subjected to harsher disciplinary measures than their British or Australian counterparts, so New Zealand's punishment of conscientious objectors to military service was in many ways harsher than that meted out in Britain. Several Members of Parliament criticised the Government for failing to follow Great Britain's lead in making some provision for religious objectors to military service in their conscription bill: Liberal MP Isitt read a constituent's letter stating that the "Act passed by the British Government was reasonable and fair" for making such a provision, and asked New Zealand to "follow its example". ${ }^{747}$ Labour MPs also took this line. Webb argued that "the least this Parliament could do was to follow the Old Country" in exempting conscientious objectors; Hindmarsh used the appeal to Britain to attack the bill on a different line, arguing that the conscription of men was more acceptable in Britain because the British Government had done far more than New Zealand to conscript wealth, taking "half the war profits". ${ }^{748}$ In the Legislative Council, Labour's J.T. Paul was particularly active

\footnotetext{
745 N.Z.L.R. 1917, vol.36, p.238-40.

746 Pugsley, On the Fringe of Hell, p.297-9.

747 NZPD 1916, vol.175, p.541.

${ }^{748}$ NZPD 1916,vol.175, p.734, 579.
} 
in pushing the argument that New Zealand should follow Britain in exempting conscientious objectors, stating that the British bill was "humanitarian" compared to the Dominion's. ${ }^{749}$ Legislative Council leader Bell agreed that "without some provision for those whose opinions on this subject England has learned to respect" the bill could not be assured of a "fair working". ${ }^{750}$ Agreeing not to divide the Council against the Bill if some such provision was made, Paul got Bell to agree to an amendment; when it reached the House, Allen proposed to reject it. ${ }^{751}$ Payne responded to this rejection by saying that the Legislative Council had acted more honourably than the House of Representatives because the Council was more "British". 752

Paul Baker has praised Allen for attempting to reach a compromise on the issue of conscientious objectors, and incorrectly credits Allen for supporting the Legislative Council's amendment. ${ }^{753}$ Isitt even pointed out at the time that Allen's proposal to reject the amendment flew in the face of his earlier claim to be willing to make some such provision. ${ }^{754}$ Ultimately, the Council refused to vote conscription in without this provision, and a compromise was reached, by which men who were members, before the outbreak of the war, of a religious body with a specific prohibition against killing in their constitution, could perform alternative service in the Ambulance or Army Service Corps, provided they were willing to serve overseas. ${ }^{755}$ This weakened provision failed to satisfy many objectors, who saw any such service as aiding the slaughter they objected to. Although conscription was not introduced immediately following the Military Service Act's passage, by November 1916 voluntary enlistments failed to make up the number of men required, and balloting began; from this point onward, the Government would have to find some way to deal with those balloted who refused to serve. ${ }^{756}$

Many simply refused to turn up for training after being balloted; the exact number who evaded service is difficult to quantify, due in large part to inaccuracies in the National

\footnotetext{
749 NZPD 1916, vol.175, p.883; 176, p.354.

750 NZPD 1916, vol.176, p.347.

${ }^{751}$ NZPD 1916, vol.176, p.497.

752 Ibid.

753 Baker, p.172.

${ }^{754}$ NZPD 1916, vol.176, p.497-8.

755 Baker, p.173.

${ }^{756}$ Baker, p.95.
} 
Register, but could be anywhere between one-thousand and eight-thousand men. ${ }^{757}$ While embarrassing for the department, those who simply evaded both the military and police caused little difficulty to military authorities. Much more problematic were those taken into camp who refused to consider themselves soldiers, don uniform or perform duties. Fearing that such men would spread ill-discipline through the ranks, New Zealand's AdjutantGeneral, R.W. Tate, sought to widen - in practise, if not in law - the provision for men of "genuine conviction and good conduct" to serve in the Ambulance Unit or Army Service Corps, rather than face having to kill other human beings. ${ }^{758}$ While very few objectors were offered, and accepted, alternative service under the provisions of the Military Service Act, many more - around 170 - were offered alternative service by the military authorities, acting outside a strict interpretation of the law. ${ }^{759}$ Nevertheless, many were either not offered this service - those whom Tate and Allen considered "defiant objectors" - or refused it, considering that such service still contributed to the war. Such men were treated as soldiers disobeying orders and subjected to a short period of military detention, followed by a month in prison, then a Court Martial and anywhere from eleven months to two years in prison. By 1918, more than one hundred such objectors were held in prison at any one time, and prison authorities were complaining of overcrowding. ${ }^{760}$

Just as their presence in camp created discipline problems for military authorities, so their continuing defiant attitudes caused problems for the prison authorities. In July 1917, with spare room on the troopship Waitemata, Colonel Potter, the Commander of Trentham Camp, decided to alleviate the discipline problem by sending fourteen "particularly troubling" objectors from prison to the front in France, though their sentences had not yet expired. Neither the men - nor the captain of the Waitemata - were informed of this plan until they were deposited onboard the ship. One of "The Fourteen" managed to smuggle a letter off the ship, so that conscription opponents learned of the transport and protested to

\footnotetext{
757 Baker, p.208.

758 P.S. O'Connor, “The Awkward Ones: Dealing With Conscience, 1916-1918," New Zealand Journal of History 8, 2 (1974), p.121-2; Baker, 193-4.

759 O'Connor, p.123; Baker, p.175.

760 "Territorial Force: Defaulters Undergoing Imprisonment" (NA: Record Group: AD1, Box: 738, Record: 10/587, Item ID: R22429869); “Territorial Force - Religious Objectors Advisory Board” (NA: Record Group: AD1, Box: 734, Record: 10/407/15, Item ID: R22429770); O'Connor, p.126; Baker, p.177-8; David Grant, Field Punishment No.1: Archibald Baxter, Mark Briggs and New Zealand's Anti-Militarist Tradition (Wellington: Steele Roberts, 2008), p.39.
} 
Allen. ${ }^{761}$ By the time they reached Europe, four were too sick to be sent to France; another four accepted stretcher-bearing duty, though one, after a spell in hospital, later recanted. Following Courts Martial, threats of execution, imprisonment and other physical punishments, including the notorious Field Punishment Number One - being tied upright to a pole near the front and left for hours, often in terrible weather - all but two of the objectors accepted some form of service. The two who held out were Mark Briggs, a socialist auctioneer, and Archibald Baxter, a Christian pacifist farmer; twenty years after the war, at the urging of his wife Millicent, Baxter wrote a book of his ordeal, which so drained him physically and mentally that he was sent into an asylum in Britain before his return to the Dominion, a fact used by authorities to discount his testimony upon return. ${ }^{762}$

The attitudes of the commanding officers towards these men varied: General Richardson, Commander of the New Zealand Expeditionary Force in Britain, and General Russell, New Zealand Division Commander in France, were responsible for sending them to the front, forcing them into the trenches - "even if they had to be carried in stretchers" - and subjecting them to field punishment; General Godley, Commander of the ANZAC forces, acquiesced in sending the men to the front and subjecting them to field punishment, but also wrote to Allen that such a practise was inadvisable, as it would encourage disobedience among the troops. With Baxter and Briggs continuing to resist, Allen had accepted defeat in November 1917 and no further shipments of objectors were sent. ${ }^{763}$ Allen in fact admitted to having failed to get the approval of the British authorities for the shipment of The Fourteen in the first place. ${ }^{764}$

Meanwhile, further letters from The Fourteen reached New Zealand. Harry Holland made their treatment a campaign issue in the Wellington North by-election of February 1918; lacking exact information regarding the treatment, the Government responded with dishonesty. ${ }^{765}$ Holland continued to pursue the issue in both parliament and public, publishing an account of the treatment of objectors - of The Fourteen as well as those kept

\footnotetext{
${ }^{761}$ Archibald Baxter, We Will Not Cease (Auckland: Cape Catley, 2003), p.67-8; H.E. Holland, Armageddon or Calvary: The Conscientious Objectors of New Zealand and "The Process of their Conversion" (Wellington: H.E. Holland, 1919), p.21-31; Baker, p.179-80, 190; Grant, p.45-6.

762 Grant, p.7, 56-7, 61-2; Baker, p.183-9; Baxter, p.206, 211-3.

763 Baker, p.182, 190-1; Holland, p.45; Grant, p.88; Pugsley, On the Fringe of Hell, p.226-35.

${ }^{764}$ Holland, p.29.

${ }^{765}$ Baker, p.192-3.
} 
back in the Dominion - in 1919, in his book Armageddon or Calvary. ${ }^{766}$ By this time, another scandal had erupted much closer to home - and thus closer to the public eye - regarding the treatment of conscientious objectors at the Wanganui Detention Barracks.

The Wanganui Detention Barracks, under the command of Lieutenant J. L. Crampton, were used to sentence soldiers guilty of offences such as disobedience against their commanding officers. Fearing, like Allen, Tate, and Godley, that the presence of objectors would encourage ill-discipline, Crampton told the objectors they would be "broken in by main force." 767 To achieve this end, Crampton had his subordinates forcibly dress objectors in uniform, handcuff them to their rifles, pushed or dragged them around the parade-yard, and punched, kicked and slammed them into walls; they also put objectors into solitary confinement and gave them bread-and-water diets. ${ }^{768}$ This treatment reached the public via a letter from several of the inmates to the New Zealand Truth newspaper; although the Truth initially approached Allen about the matter rather than going to print, Holland soon got hold of the letter and had it printed in the Maoriland Worker. ${ }^{769}$ Although he initially responded by attempting to suppress further correspondence from the objectors, Allen also commissioned a Magisterial Inquiry into the matter. ${ }^{770}$ The Magistrate, J.G. Hewitt, found that the allegations were largely accurate, and secured the transfer of all the men who had been carrying out Crampton's orders; Crampton was left in charge until a replacement could be found. ${ }^{771}$

Hewitt sent his report to Allen on 21 September 1918; besides changing the staff of the Barracks, Hewitt recommended using the institution for "military offenders only", not objectors - and appointing outside civilians visitors to inspect its management. ${ }^{772}$ On 21 October, Allen responded, noting that orders had been given not to send any objectors to the Barracks in future, but disagreeing with the recommendations to remove the staff or appoint civilian inspectors. The Adjutant General, Tate, agreed that the staff should be removed, but argued that Crampton should remain in charge: although "he acted illegally in

\footnotetext{
766 Holland; NZPD 1918, vol.183, p.93-4, 1091; vol.184, p.246-50.

767 “Hewitt Report," p.6, 14, in “Territorial Force: Defaulters Undergoing Imprisonment 1918-1919” (NA: Record Group: AD1, Box: 738, Record: 10/566/1, Item ID: R22429858); Holland, p.137, 142.

768 "Hewitt Report"; Holland, p.126-30; Baker, p.194-6.

769 New Zealand Truth, 6 July 1918, p.6.

770 Baker, p.195-6.

771 "Hewitt Report"; Holland, p.134-43; Baker, p.199.

772 “Hewitt Report," p.16.
} 
applying force for which there was no legal warrant" he did so believing "that he was within his rights and that he was acting according to the custom of the service"; furthermore, the Adjutant General refused to "believe that men who refuse to obey orders and practice open defiance are treated gently in any penal institution whether civil or military", concluding that Crampton "acted as he did because he thought it was right and not from any inhumane inclination", that he acted "with courage and decision", and that lesser measures would not "have broken in determined, defiant Irishmen". The Director of Personnel Services for the Army, Major Osbourne-Lilly, similarly argued that Crampton was "possessed of a great amount of courage" and that he had to act in such a "normal" manner to ensure that the defiance of the objectors did not affect the discipline of the barracks as a whole, that it was a "pity" that such men should receive better treatment than fighting soldiers - that in future all objectors should be court-martialled - and that the appointment of civilian visitors should be opposed. Osbourne-Lilly felt that Crampton had "done good service at Wanganui." 773

Three days after drafting his response to the Hewitt Report, Allen told Holland in Parliament that he had still not seen the report; on 2 December, he again told Holland the report was not available. ${ }^{774}$ Four days later, after questioning by both Holland and Isitt, Allen stated that all the staff except Crampton (who had to stay on due to the influenza epidemic) had been removed, and that "he could not see that there was any object in wasting the time of the House over a discussion upon the report now."775 That same month, the report's findings were finally published; simultaneously, the public also learnt of Crampton's Court Martial in December 1916. While serving as Provost Martial and Judge of the Native Court in New Zealand-occupied Samoa, Crampton was charged with the assault of a native woman; though cleared of sexual impropriety, the court found him guilty of the assault, but sentenced him with only a reprimand. ${ }^{776}$

\footnotetext{
773 Hon. Minister of Defence, Wanganui Detention Prison, 21 October 1918; Colonel, Adjutant General, 15 October 1918; Major, Director of Personal Services, 10 October 1918, in "Territorial Force: Defaulters Undergoing Imprisonment 1918-1919" (NA: Record Group: AD1, Box: 738, Record: 10/566/1, Item ID: R22429858).

774 NZPD 1918, vol.183, p.3, 606.

775 NZPD 1918, vol.183, p.860-1.

${ }^{776}$ Dominion, 11 December 1918, p.4; Dominion, 17 December 1918, p.6; Baker, p.194.
} 
The newspapers of the country contained a wide variety of responses to Hewitt's findings. While the Christchurch Ministers' Association publicly expressed their outrage at the methods used by Crampton, a group of Wanganui Ministers wrote to the press to express their disagreement with this outrage. ${ }^{777}$ The Dominion defended Crampton's record in Samoa, stating that his assault on the woman in question was justified, and that it had "provided an opening for the Germans and their sympathisers to put in operations their schemes against himself"; on the other hand, a letter to the Sun argued that the Samoan incident showed the officer "clearly had no right to be appointed" to head the Wanganui Barracks. ${ }^{778}$ Correspondents to both papers complained that one of Crampton's subordinates had been dismissed from service for giving evidence against Crampton at the inquiry. ${ }^{779}$

A number of journalists sought to make clear that they held "no brief for any man who shirks his responsibility to his country", that the men brutalised by Crampton included "the shameless coward and the open rebel", but that nevertheless they ought not to be treated with such "vindictive and ferocious brutality" in a country professing the civilised ideal of "British fair play"; that such treatment was repugnant to "all but a mere handful of Englishmen the world over." 780 The New Zealand Herald argued that "military prisoners, however misguided or stubborn or disloyal", should not "be subjected to such outrage with impunity", and that the matter was "far too serious to be brushed aside with a bare announcement that the whole staff" had "been removed". ${ }^{781}$ Other papers noted that, because the objectors had already been sentenced to prison for refusing to serve, punishing them further when they refused to follow orders meant they were being punished "twice for the same offence", and that this practice was "totally foreign to the principles of British justice." ${ }^{782}$ Taking the opposite view, an editorial in the Rangitikei Advocate, titled "Howls of the Shirker", reminded readers that with their "lack of manly civic attributes, such as patriotism," and by their "sullen, intractable and pig-headed opposition to authority", the

\footnotetext{
777 New Zealand Herald, 12 December 1918, p.4; Wairarapa Daily Times, 14 December 1918, p.4.

778 Dominion, 13 December 1918, p.4; Sun, 9 December 1918.

779 Sun, 9 December 1918; Dominion, 19 December 1918, p.5.

780 Waimate Advertiser, 14 December 1918; Lyttelton Times, 7 December 1918; Wairarapa Daily Times, 14 December 1918, p.4; Wanganui Chronicle, 17 December 1918, p.6.

${ }^{781}$ New Zealand Herald, 7 December 1918, p.8.

782 Evening Post, 7 December 1918, p.6;
} 
military objectors were "little better than the brutes, and ordinary humane, restrained methods of punishment have no effect with them." 783

As soon as Crampton learned of Hewitt's findings, he demanded a Court Martial in order to clear his name. ${ }^{784}$ The Court found Crampton not guilty of all eleven charges of mistreating soldiers. ${ }^{785}$ Unlike Hewitt, but like Justice Chapman when investigating allegations of cruelty towards German internees on Somes Island, those conducting the Court Martial gave little weight to the evidence given by people who were disloyal. Holland called the Court Martial "nothing more or less than a piece of whitewashing machinery to save Lieutenant Crampton", who was subsequently appointed Area Commander of Wanganui; a number of other labour leaders and peace activists wrote to Allen to complain. ${ }^{786}$ Unlike the history of The Fourteen, which returned to public memory by the 1960 s thanks to Baxter's book, Crampton's actions faded from view. Writing in the 1970s on conscientious objectors during the war, P.S. O'Connor had only this to say of the incident: "Other men were ill-treated for a time at Wanganui in 1918, but this was stopped as soon as it came to light." ${ }^{\prime 78}$ It wasn't until Paul Baker's King and Country Call appeared in 1988 that the incident entered the New Zealand historical record, despite the efforts of Holland. ${ }^{788}$

In the same month that the Hewitt report was published, the Government passed the Expeditionary Forces Amendment Act, extending the deprivation of conscientious objectors' civil rights for ten years after the war's end: objectors could not vote or hold public office or employment for this period. The following July, Allen compiled a list of 2600 men to be disenfranchised under this Act, and the last objectors remaining in prison were released at

\footnotetext{
${ }^{783}$ Rangitikei Advocate, 10 December 1918; Waimate Advertiser, 14 December 1918.

784 General Headquarters, 17 December 1918, in "Territorial Force: Defaulters Undergoing Imprisonment 19181919" (NA: Record Group: AD1, Box: 738, Record: 10/566/1, Item ID: R22429858); NZPD 1919, vol.185, p.1428. 785 “Court martial of Lt JW Crompton, December 1918 - July 1920” (NA: Record Group: AD10, Box: 23, Record: 45/333/2, Item ID: R3885615); Baker, p.200-1;Holland, p.145-58.

${ }^{786}$ NZPD 1919, vol.184, p.245-6; "Territorial Force - Conscientious objectors - Treatment and complaints" (NA: Record Group: AD1, Box: 738, Record: 10/566/2, Item ID: R22429859).

${ }^{787} \mathrm{O}^{\prime}$ Connor, p.133. In an end-note, $\mathrm{O}^{\prime}$ Connor claims that the details which emerged at the Court Martial were "a good deal less lurid than what was originally alleged", yet such details included one witness, Moynihan, claiming a rifle was banged against side of his face during drill "till the blood was streaming down over the uniform"; another, McConville, also stated he had been bashed on the neck with a rifle-butt: O'Connor, p.136; “Court martial of Lt JW Crompton, December 1918 - July 1920." ${ }^{788}$ Baker, p.194-201.
} 
the end of $1920 .{ }^{789}$ The conservative Dominion newspaper argued the deprivation of objectors rights for ten years did not go far enough: "The right penalty for most of these men would be not disenfranchisement, either for a limited period or for life, but deportation, and this penalty might well be considered but for the practical difficulty of finding a country that would consent to receive them." 790

\section{Regulating Manpower IV: Censorship, Surveillance and Policing Labour}

Besides the conscription of troops and the specific persecution of objectors to conscription, and enemy aliens, the wartime government in fact introduced a range of legislation aimed at restricting the actions of all New Zealanders, when these actions were considered detrimental to the war effort. The War Regulations Act 1914 gave the Governor the power to issue "such regulations as he thinks necessary for the prohibition of any acts which in his opinion are injurious to the public safety, the defence of New Zealand, or the effective conduct of the military or naval operations of His Majesty during the present war"; punishments for breaching such regulations were up to three months in prison, or up to twelve months if the offender was an alien. ${ }^{791}$ Regulations issued on 19 July 1915 made it an offence to "publish, or cause or permit to be published, any statement or matter likely to interfere with the recruiting, training, discipline, or administration of His Majesty's Forces, whether by sea or land, or with the effective conduct of the military or naval operations of His Majesty or his Allies in the present war, or likely to be injurious to the public safety in the present war, or to prejudice His Majesty's relations with foreign powers, or any false reports relative to the present war and likely to cause alarm, or any statement or matter which in any manner indicates disloyalty or disaffection in respect to the present war."792 Further regulations issued on 20 September that year made it an offence to "encourage, advise, or advocate violence, lawlessness, or disorder, or express any seditious intention", and introduced permits for the trade of firearms. ${ }^{793}$ Regulations issued on 11 October

\footnotetext{
789 Baker, p.201; O'Connor, p.130; Barry Gustafson, Labour's Path to Political Independence: The Origins and Establishment of the New Zealand Labour Party 1900-19 (Auckland: Auckland University Press, 1980), p.116. 790 Dominion, 10 December 1918, p.4.

791 War Regulations Act 1914, s3, s4.

792 New Zealand Gazette, 19 July 1915, p.2473-4; Hill, The Iron Hand in the Velvet Glove, p.350.

${ }^{793}$ New Zealand Gazette, 20 September 1915, p.3263-4.
} 
allowed the Minister of Defence to "prohibit the sale of any book or other publication the sale of which he deems injurious to the public interest in respect of the present war."794

Such regulations were initially used, not against peace activists of labour leaders critical of the war, but, in the words of Paul Baker, against "disgruntled, imbalanced, ill-tempered, or alcoholic individuals such as the Waimate farmer who said that British capitalists had caused the war and the New Zealanders at Gallipoli should all have been killed", and who was fined f5. ${ }^{795}$ However, once first National Registration and, later, conscription arrived, and Labour leaders in particular took a stand, they came under legal fire for interfering with recruiting. MP Paddy Webb's arrest and imprisonment for refusing service was the most prominent example of such government action, but he was far from alone. In October 1915 Egerton Gill, secretary of the Auckland Freedom League, was fined $f 50$ for distributing literature encouraging League members to protest against having to fill in their registration cards; over the following two months, National Peace Council secretary Charles Mackie had so much mail confiscated that he told friends not to bother writing to him anymore. ${ }^{796}$ In the Supreme Court, Gill's lawyer stated that the circulars he distributed "had nothing to do with recruiting" and were "perfectly legitimate" as conscription was "not the law of the land now". Opposing counsel argued that while Gill's "propaganda" may have been "comparatively harmless during peace," during the war it was "the duty of all loyal persons to refrain from any controversy" that might "be calculated to prejudice the country's cause." Rejecting Gill's appeal, Justice Chapman stated that Gill's circular was "a libel" and a "leading question" which could prejudice the attitudes of "waverers" towards enlistment. ${ }^{797}$

Prior to their arrival in parliament via the by-elections of 1918 , both Robert Semple and Peter Fraser were arrested in December 1916, under the War Regulations of 20 September 1915 , for speaking against conscription - Semple had told miners not to be "lassoed by that Prussian octopus"; both served twelve months. ${ }^{798}$ Semple appealed to the Supreme Court in a vain attempt to argue that the Military Service Act was "not within the competency of the

\footnotetext{
794 New Zealand Gazette, 11 October 1915, p.3485.

795 Baker, p.45.

796 Baker, p.77-8.

797 N.Z.L.R. 1916, vol.35, p.1202-8.

798 Len Richardson, "Semple, Robert," in Dictionary of New Zealand Biography, Te Ara - the Encyclopedia of New Zealand, updated 30-Oct-2012, URL: http://www.TeAra.govt.nz/en/biographies/3s11/semple-robert; Tim Beaglehole, "Fraser, Peter," in Dictionary of New Zealand Biography, Te Ara - the Encyclopedia of New Zealand, updated 25-Sep-2013, URL: http://www.TeAra.govt.nz/en/biographies/4f22/fraser-peter.
} 
Parliament of New Zealand to enact, in that it purported to control and compel the services and conduct of persons beyond New Zealand". This argument had no legitimacy, and Stout and his fellow judges unanimously rejected it. ${ }^{799}$ By the war's end, the state had convicted 208 New Zealanders for seditious or disloyal activities, and sentenced 71 to prison. ${ }^{800}$

Much more serious for the government was the industrial action taken by mining and waterside unions against conscription, which directly followed the arrests of Semple and Fraser. At an Anti-Conscription Conference in January 1917, several unions agreed to a general strike to begin in early February; although this planned action was nominally against the Military Service Act, in fact it coincided with negotiations over employment conditions between the miners' and watersiders' unions, and instead of strike action, these unions embarked on a go-slow. ${ }^{801}$ Fortunately Massey, who advocated taking a hard line, using the War Regulations to squash the industrial action, was out of the country at the time. ${ }^{802}$ James Allen, acting Prime Minister, instead negotiated with the unions; this tactic initially failed to end the go-slow, and on 3 April the government opted to follow Massey's advice and arrest nine miners' union leaders, resulting in a strike by all of the West Coast mines four days later. ${ }^{803}$ Allen and Liberal cabinet minister W.D.S. MacDonald met with delegates of the striking unions on 21 April. Although, as Allen wrote to Massey, the delegates "started out to fight on the conscription issue, and said that was all they were fighting on," they ultimately "abandoned the conscription issue altogether" and agreed to return to work on 25 April in return for better conditions, and an undertaking to categorise miners as essential workers, not to be conscripted, which Allen suspected was their real intention all along; the watersiders similarly agreed to end their go-slow. While the government would not agree to simply release the nine arrested leaders, they did promise not to "press for a penalty" when the men appeared in court. ${ }^{804}$ However, a day after returning to work, some of the miners struck again, undermining the agreement; instead of exempting all miners from military duty, many were forced to attend training camps before being returned to the

\footnotetext{
${ }^{799}$ N.Z.L.R. 1916, vol.36, p.273-291.

800 Hill, The Iron Hand in the Velvet Glove, p.352.

801 Baker, p.159.

802 William Massey to James Allen, 2 January 1917, p.5 (NA: Record Group: Allen1, Box:9, Item ID: R22319675).

803 Baker, p.160.

804 James Allen to William Massey, 26 April 1917, p.3-6 (NA: Record Group: Allen1, Box:9, Item ID: R22319675).
} 
mines, and industrial action dragged on into June. ${ }^{805}$ Although the ongoing action and negotiations caused a coal shortage and other difficulties for the government, Allen's moderate tactics ensured no serious disruptions to the wartime economy; on the other hand, his one attempt at following Massey's advice had inflamed the matter.

For police, the threat of labour action against the war meant an increase in surveillance duties, with officers ordered to spy on unions. ${ }^{806}$ In September 1920, these duties were made routine, with a detective in each of the four main centres detailed to surveillance work. Graeme Dunstall has written that the system initiated in 1920 was "no mere continuation of the police monitoring of opposition to the war effort". ${ }^{807}$ While the changes were certainly significant, it is nevertheless the case that the impetus for these activities came out of wartime anxieties; the fact that surveillance only increased after the return of peace demonstrates that these anxieties persisted with the uneasy peace (which included the new fact of international Bolshevism), and further indicates how wartime increases to the state's legal powers changed both public and official perceptions about the level of acceptable state activity. Also continuing on from the War Regulations were the tougher firearms restrictions which persisted once the war came to a close, with a new Arms Act passed in 1920.808

\section{Regulating Manpower IV: Policing Liquor and Imprisoning Maori Objectors}

The war also saw a new tightening of liquor laws. Although the votes of soldiers famously defeated the 1919 referendum on prohibition, new measures included the prohibition of "treating" (buying drinks for another person), a prohibition aimed at stopping people from getting soldiers drunk; the six o'clock closing of pubs; and the banning of barmaids. ${ }^{809}$ Although these measures would come to have a significant and long-lasting impact on New Zealand's drinking culture, at the time the most important use of the liquor laws was in the

\footnotetext{
805 James Allen to William Massey, 28 April 1917, 23 May 1917, 9 June 1917 (NA: Record Group: Allen1, Box:9, Item ID: R22319675); Baker, p.162.

806 Hill, The Iron Hand in the Velvet Glove, p.353.

807 Dunstall, A Policeman's Paradise?, p.253.

808 Dunstall, A Policeman's Paradise?, p.50-1.

${ }^{809}$ AJHR 1917, H-16, p.7; AJHR 1919, H-16, p.11; Conrad Bollinger, Grog's Own Country (Wellington: Price Milburn \& Co., 1959), p.68-74.
} 
prosecution of the Maori prophet Rua Kenana. Rua was imprisoned in 1915 on a charge of breaching the liquor laws by supplying alcohol without a license, a charge which had been held over since 1911; released after three months, he was then subject to police surveillance. ${ }^{810}$ In 1916, Rua was charged with sedition for discouraging his followers from joining the war effort; Commissioner Cullen personally led the invasion of his home, Maungapohatu, on Sunday 2 April, even though the arrest involved the use of warrants based on the sale of liquor offences - warrants not legally executable on a Sunday. ${ }^{811}$ The arrest devolved into a gun-fight, and police shot dead two of Rua's followers, including his son Toko Rua; several policemen present later said the gunfire was unnecessary, and the fault of the Commissioner. ${ }^{812}$ Since the arrest had been unlawful, charges of resisting and obstructing were dropped; the jury at his trial found Rua Kenana guilty of "moral resistance" but not sedition, yet in spite of their appeal for leniency, Justice Chapman sentenced him to a year in prison followed by eighteen months' reformative detention; several of the jury later petitioned parliament, asking to grant him a pardon. ${ }^{813}$

Besides Rua Kenana, the other prominent Maori opponent of military service was Princess Te Puea. While some other tribes had contributed men to the war effort, Te Puea's Waikato people resisted for historical reasons, stemming from the way the government had attacked them during the $1860 \mathrm{~s}^{814}$ In June 1917, conscription was extended to Maori, and a showdown was imminent. Because other tribes had already contributed soldiers, Allen targeted conscription specifically at the Waikato. ${ }^{815}$ After a long delay as the government sorted out a register of men they considered eligible, 209 were finally balloted in May 1918, and police sent a small force to Mangatawhiri marae in June, where Te Puea and hundreds of her people were gathered. Police arrested seven supposed defaulters, including a brother of the King; further arrests followed over the coming months, but none had been sent overseas by the war's end. Many were, however, deprived of their civil rights for the next decade. ${ }^{816}$

\footnotetext{
$810 \mathrm{Hill}$, The Iron Hand in the Velvet Glove, p.382-3.

${ }^{811}$ Hill, The Iron Hand in the Velvet Glove, p.383-4.

812 Derby, p.74-89; Hill, The Iron Hand in the Velvet Glove, p.385-6; Baker, p.215.

${ }^{813}$ Hill, The Iron Hand in the Velvet Glove, p.387-8; Derby, p.90-8.

814 Baker, p.213;

815 Baker, p.218.

816 Baker, p.219-20.
} 


\section{Regulating Morality: Policing Sex and Religion}

The censorship of supposedly seditious utterances, and prohibition of material believed damaging to the war effort, was accompanied by new increases to moral censorship. The Indecent Publications Act 1910 made it an offence to publish any material relating to venereal disease - or even irregular menstruation. ${ }^{817}$ The Social Hygiene Act 1917 increased this prohibition, and made it an offence, punishable by a fine of between twenty and one hundred pounds, to employ any person with a communicable venereal disease, in the handling of foodstuffs. ${ }^{818}$ Meanwhile, police used the War Regulations to launch a campaign against "one woman brothels", in the name of protecting the troops. ${ }^{819}$

Although this campaign received public support as a means to protect troops from venereal disease, the issuing of prophylactic kits to troops stationed overseas, organised by Ettie Rout, attracted public outcry; following the advice of General Richardson in England and the Surgeon General in New Zealand, Allen allowed Rout to issue free prophylactic kits, but sought to keep the matter secret, prohibiting the publication of her activities, publicly stating that he had no sympathy for her actions; responding to Holland's criticism of her activities, Allen told parliament that neither the Government nor the Army had "any control over Miss Rout whatever." 820

As well as managing public outrage over the existence of venereal disease, the government was faced with the difficult task of moderating sectarian tensions, and again relied upon censorship. Protestant preacher Howard Elliot created, during the war, a Protestant Political Association, which publicly claimed that Catholics were, in general, disloyal to the war effort. Solicitor-General Salmond sought to monitor Elliot's divisive activities by instructing the Military Censor, in December 1916, to control correspondence to and from Elliot's post box. Elliot realised this was going on, and pressure from his followers forced a government inquiry; Salmond's former subordinate, Hubert Ostler, representing Elliot, charged that Salmond's actions had been "unconstitutional and quite illegal"; Herdman later defended

\footnotetext{
817 Indecent Publications Act 1910, s6.

818 Social Hygiene Act 1917, s6.1.

${ }^{819}$ NZ Truth, 8 June 1918, p.5; Bronwyn Dalley, "Lolly Shops 'of the Red-Light Kind' and 'Soldiers of the King'," New Zealand Journal of History 30, 1 (1996), p.3.

${ }^{820}$ NZPD 1919, vol.185, p.1426-9; Jane Tolerton, Ettie: A Life of Ettie Rout (Auckland: Penguin Books, 1992), p.168-9, 185-6.
} 
them as necessary. Salmond's biographer has said of the surveillance that "Salmond was aware that there was no proper legislative basis for the censorship, but considered that the needs of the situation justified the risk." ${ }^{821}$ This is entirely in line with Salmond's views on executive power as established earlier in this chapter.

\section{Conclusion}

Celebrating the return of peace, Police Commissioner O'Donovan praised a lack of “definite organized public upheaval" in spite of the rising cost of living, the "dislocation of labour" and the "hampering of industries and commerce." O'Donovan remarked that the "good sense of a community enjoying the most liberal constitutional privileges" had "asserted itself in every emergency and promises to prevail at all times over passions." 822 The Commissioner's platitudes obscured the continual erosion of British constitutional liberties over the course of the war, as documented in this chapter. Yet this sense that being British inherently meant being free was used to defend the very erosion of British freedoms.

Introducing conscription, James Allen argued that the "discipline of to-day" was necessary to secure "the traditions of the Old Land" for the future. ${ }^{823}$ Legislative Councillor Barr stated that, far from interfering with "the liberty of the subject", conscription would uphold "what we understand in the British Empire as liberty." 824 Labour Members of Parliament Paddy Webb, James McCombs and J.T. Paul disagreed, arguing that conscription would "Prussianize" the Dominion and thus undermine the justification for waging war in the first place. ${ }^{825}$ Reform Member Thomas Field and Liberal Member William Jennings shared these concerns, but felt true "Prussian militarism" could be avoided by amending the Military Service Bill to ensure civilian oversight. ${ }^{826}$

Other parliamentarians rubbished the suggestion that a British state could ever be described as Prussian. Two Dunedin Members - Liberal Thomas Sidey and Reformer Charles Statham -

\footnotetext{
${ }^{821}$ Frame, Salmond, p.175-7.

822 AJHR 1919, H-16, p.9.

823 NZPD 1916, vol.175, p.491.

824 NZPD 1916, vol.175, p.899.

825 NZPD 1916, vol.175, p.504, 548. 567, 884-5.

${ }^{826}$ NZPD 1916, vol.175, p.563, 591.
} 
stated that parliamentary control of the British Military meant fears of "Prussian militarism" were either "unfounded" or just "silly".827 Liberal Leonard Isitt and Reformer Richard Hudson simply dismissed such fears as "piffle" and "balderdash" without providing any reasoning. ${ }^{828}$ Liberal Councillor George argued that the Military Service Act did not introduce Prussian Militarism or even conscription, as New Zealand's troops were to be well-paid for their service. ${ }^{829}$ Francis Dillon Bell reasoned that, since Britain's ally France also relied upon conscription, it was wrong to couple "militarism" together with the words "Prussian" or "German". 830 Other members pointed out that Britain, and New Zealand, had possessed some form of compulsion in the past, for instance during the Maori-Pakeha conflicts of the mid-nineteenth century. ${ }^{831}$

Contrasting with this argument over whether detestable Prussian militarism was being introduced, some Members suggested that a degree of Prussianization was not entirely undesirable in wartime. Reformer James McColl Dickson claimed that, while he did "not want to say anything in favour of the German system", nevertheless "German militarism" was "a very effective weapon", and that trying to fight it with a volunteer system was like bringing a club to a rifle fight. Furthermore, with reference to "the Prussian military spirit or the French military spirit," Dickson "should be very sorry to think that the military spirit of our nation - the British nation - was in any way deteriorating" as "nations possessing a military spirit have always been the dominant nations". Having provided what appeared to be an outright defence of Prussian militarism, Dickson concluded that he had faith that, at the conclusion of the war, democracy would reassert itself by putting down "anything pertaining to or approaching the Prussian military system." 832

In essence, Dickson's argument was that a military system resembling Germany's amounted to a tyranny in peacetime, but a necessity in time of war, and in this view he was certainly not alone. Liberal George Witty said that conscription had "brutalized" the Central Powers and brought about the beginning of the war, but that an organised system of training men

\footnotetext{
827 NZPD 1916, vol.175, p.510, 527.

828 NZPD 1916, vol.175, p.538-9, 545.

${ }^{829}$ NZPD 1916, vol.176, p.10.

830 NZPD 1916, vol.176, p.17.

${ }^{831}$ NZPD 1916, vol.175, p.595-6, 600, 628.

832 NZPD 1916, vol.175, p.600.
} 
to fight for Britain had become a necessity. ${ }^{833}$ Another Liberal, Thomas Wilford, argued that even if compulsion was "contrary to British traditions", such traditions did not count in the current war. ${ }^{834}$ Four Legislative Councillors repeated the refrain that British traditions and liberties had to be suspended for the duration of the conflict. ${ }^{835}$ Reform Representative Robert Wright, after acknowledging that the principal of the Bill was "absolutely new to the people of the British Empire" and struck at "the fundamental idea" accepted by generations of Britons - "namely, that a Britisher shall not be compelled to fight for his country" - the support for this change was "marvellous". 836 The Prime Minister took this support for change further, arguing that as the military "unpreparedness" of the British Empire had allowed the First World War to erupt, the Empire would have to alter its attitude towards compulsion permanently, by retaining some form of "Imperial conscription" even after the war had been won. ${ }^{837}$

Observing this debate between British New Zealanders over whether conscription meant Prussianization - and, if it did, whether this was Prussianization was unfortunately necessary - Apirana Ngata was moved the comment that, given British military policy in the past, the way his colleagues were framing the debate was a little ridiculous:

\footnotetext{
"Just one word about Prussianism, before I sit down. The English people are the most curious on earth - at least, the most curious that I have met - and the most contradictory. Prussianism with them is like a taipo; but I do not think that very many of them understand what Prussianism is - at least, did not understand what Prussianism was before they objected to it. The British race will have to swallow the pill of Prussianism before they can be reorganized. They have got to swallow it. A dose of Prussianism will be the best possible tonic for them. Prussianism, as I understand it, simply means organizing yourselves in every respect so as to carry out your work as human beings on this earth most efficiently. That is Prussianism." 838
}

\footnotetext{
${ }^{833}$ NZPD 1916, vol.175, p.759-60.

${ }^{834}$ NZPD 1916, vol.175, p.716.

835 Buddo, Earnshaw, Barr, and Young: NZPD 1916, vol.175, p.621; vol.176, p.2-3, 348, 637.

836 NZPD 1916, vol.175, p.553.

837 NZPD 1916, vol.175, p.754.

838 NZPD 1916, vol.175, p.614
} 
Maui Pomare similarly refused to indulge in any British abhorrence for the term Prussian: It had become "absolutely necessary" that the British Empire win the war, and if that meant "Prussianizing the people of this country in order to win the war, let it be Prussianizing." He "did not care" what military organisation was called, "for the British Prussianization would be as different from the Prussian Prussianization as the North is from the South," and he preferred "the British every time." 839

Although exposing the contrary nature of their colleagues' discussion of "Prussianism", Ngata and Pomare came to the same conclusion as other supporters of the Military Service Act, and indeed of the other erosions of liberty introduced for the sake of the war effort: that Britain was fighting for liberty, and that while this fight meant restricting liberty, nevertheless parliamentary oversight ultimately meant the distinction between the free British Empire and their unfree opponents remained to justify the conflict.

The major problem with this argument was the lack of democracy during the war. The election of late 1914 had gone ahead as scheduled - in spite of the concerns of Liberal leader Joseph Ward - and demonstrated that the population of New Zealand overwhelming voted for the same politicians who voted unanimously to declare war that August. Yet there had been no suggestion at the time of this election that the Government would bring in a system of conscription for overseas service, and the next general election, scheduled for late 1917, which would have allowed the public to have their say on the recently introduced conscription system, was twice delayed, eventually taking place in late 1919, a year after the end of the war. While Massey's Government retained power at this election, those who had publicly opposed conscription had already had their civil liberties, including the right to vote in general elections, confiscated as punishment for their opposition. Consequently, any claims that the presence of democracy proved the difference between British and Prussian militarism in New Zealand ring hollow.

As a counter-argument, it is worth noting that had a free election taken place in 1917, New Zealand would almost certainly not have voted out the Government that had introduced conscription. The Labour Party fought the Christchurch local body elections of 1917 on an anti-conscription platform, making this the major election issue in the city with the largest

${ }^{839}$ NZPD 1916, vol.175, p.519. 
peace movement in the country. Labour's share of the vote declined in comparison with the previous elections, largely due to an increased turnout of voters supporting their opponents. ${ }^{840}$ The Maoriland Worker acknowledged this as a victory for conscription, arguing that there was no use making excuses when two thirds of the population voted in favour of conscription and "cheap soldiers." 841

On the other hand, Labour's victories in three by-elections during 1918 - fought partly on an anti-conscription platform - suggest that opposition to conscription continued to grow as it was implemented, and that it could be a successful basis for a campaign. While Harry Holland had but a narrow victory in the Grey seat, made vacant by the imprisonment of Labour's Paddy Webb for resisting his conscription, Robert Semple and Peter Fraser won Wellington seats at the end of the year by enormous margins, both double their nearest opponent - and Fraser's nearest opponent was an Independent Labour man, with the Government's candidate coming in a distant third. An Independent Labour candidate also beat the Government's candidate in the Taranaki by-election that year, and the Labour Party's candidate lost another by-election, in Palmerston, by a narrow margin. Furthermore, the men elected - Holland, Semple and Savage - were all prominent militants, to the left even of Labour, and all outspoken against conscription. ${ }^{842}$

These victories, set against Labour's defeat in the Christchurch local body elections, suggest the unreliability of extrapolating from the election results we have, to try and guess the probable outcome of a referendum on conscription. Certainly, New Zealand's greater reputation for loyalty and following Britain's lead - shown, for example, in the fact that New Zealand, but not Australia, allowed British military authorities to execute New Zealand troops - tells us that we cannot presume that just because Australia twice voted to reject conscription, New Zealand would have done so; but we cannot simply presume the opposite, either.

While an apparent majority of New Zealanders continued to support the Government, and the Government's policies of restriction and compulsion for the purposes of the war effort,

\footnotetext{
840 Loveridge, "Sentimental Equipment," p.275.

841 Maoriland Worker, 9 May 1917, p.7; Baker, p.162-3.

${ }^{842}$ Gustafson, 132-6; P .J. O’Farrell, Harry Holland: Militant Socialist (Canberra: Australian National University, 1964), p.83; Baker, p.164-6; Holland, p.35.
} 
it is nevertheless still significant that democracy was put on hold, particularly given the strengthening of sedition and censorship laws: the war and the methods imposed to fight it were not subject to the robust debate which is vital to a liberal democracy, and which was appealed to in parliamentarians' arguments that British militarism could never be equivalent to Prussian militarism.

The war saw a significant erosion of the "British liberties" of New Zealanders, even though the war was fought in the name of British freedom. In increasing control over New Zealanders for the needs of Britannia-at-war, the government tied an increase in state power to the demands of the British Empire as a whole. This relationship continued in other ways once war ended: in cases before the Dominion's courts, New Zealand's lawmakers paid more deference to British precedence than they had in the pre-war era. ${ }^{843}$

${ }^{843}$ Peter Spiller, Jeremy Finn, Richard Boast, A New Zealand Legal History (Wellington: Brookers, 1995), p.116. 


\section{Conclusion}

Over the length of this thesis, I have shown how the Massey Government of the First World War significantly increased both the economic size and legal reach of the New Zealand State, in their aim of supporting Great Britain's war effort. I have argued that this growth in many ways tied New Zealand closer to the Mother Country. With the concept of the military-agrarian state, I have linked together the two weightiest chapters of this thesis - on economics, and on the law - showing how restrictive war legislation and the conscription of men were placed in a mutually-beneficial relationship with the export of primary produce to Britain; these exports in turn came under greater New Zealand - and British - government control, through the Imperial Commandeer, which was continued, to some extent, after the war via the producer boards; this export trade to Britain was reinforced as the bedrock of the Dominion's economy.

In making this argument, I have stated that other historians are incorrect to use the term "nation" to describe the New Zealand of this era. New Zealand was sometimes perceived, by its citizens, as "becoming" a nation, but the nation with which they identified was, overwhelmingly, Britain, and the use of "nation" to describe the Dominion alone is misleading.

In addition to this primary argument, I have attempted to make two other contributions to the history of the New Zealand government in the First World War. One is to address the recent rehabilitation of the Massey Government. Miles Fairburn's 1996 essay “The Farmers Take Over" challenged the commonly held view of Massey as little more than a narrowminded bigot and anti-unionist bully; this reassessment reached a peak with the 2011 collection of essays, A Great New Zealand Prime Minister? Reappraising William Ferguson Massey, edited by James Watson and Lachy Paterson. Important supplements to the reassessment, with particular relevance to this thesis, include Ashley Gould's thesis on the Soldier Settlement Scheme, and Justin Strang's thesis on welfare policy. While these attempts to reappraise the legacy of Massey and his Cabinet have served as important correctives to some of the more extreme expressions of the Massey-as-villain tradition, I have argued that they sometimes go too far. In entering this debate, I accept that it is far 
from over, and hope that my own doubts about the reassessment will provoke others to enter the fray, whether they share my doubts or seek to counter them.

Finally, while in most of this thesis I have been readdressing subjects previously addressed by other historians, and responding to their analysis, one area emerged which has not been mentioned in any of the historiography relating to this topic: the clash between Robert Stout and John Salmond over the legal reach of the state and, in particular, the manner in which Salmond's attitude towards evidence law helped the Government essentially do away with the laws of evidence in their war legislation. Setting out on this thesis, I was unsurprisingly unaware of this part of the history, but came to see documenting it as a vital contribution to the historical record of the wartime government, and indeed to the legal history of the country.

Ultimately, then, I have not only suggested that the wartime government significantly expanded the size and reach of the state, or did so in ways that tied New Zealand closer to Britain, but that doing so served the interests of the Empire in ways that were detrimental to the well-being of the people of New Zealand. While the war was used to justify, for example, taking away the right to silence for the accused, such measures were not necessary for the successful prosecution of the war. Consequently, while there is no sharp divide between the interests of the Empire and the interests of the "average New Zealander" - as New Zealanders benefited in many ways from the success of Empire - I cannot but conclude that Massey and his government prioritised the interests of Empire over and above the interests of their people. The state grew, and grew tighter to Britain, more out of genuine Imperial loyalty than a belief that Empire simply happened to be what was best for New Zealanders. 


\section{Bibliography}

\section{Primary Sources}

\section{Publication Series}

AJHR: Appendices to the Journals of the House of Representatives

N.Z.L.R.: New Zealand Law Review

NZPD: New Zealand Parliamentary Debates

New Zealand Gazettes

New Zealand Official Year Books

Various Newspapers

Various Statutes

\section{Alexander Turnbull Library (AT)}

W.F. Massey, "The Call of Empire: Speeches and Interviews in Great Britain, 1916-7," (AT: Micro-MS-0843).

Sir David Smith, "Sir Alexander Herdman" (AT: MS-Papers-11112-012)

\section{New Zealand National Archives (NA)}

Col. E. Heard, "Waterside-Workers Strike - October, November, December 1913" in "Aid to the Civil Power" (NA: Record Group: AD11, Box: 1, Record: 2/1, Item ID: R3885678).

“Court martial of Lt JW Crompton, December 1918 - July 1920" (NA: Record Group: AD10, Box: 23, Record: 45/333/2, Item ID: R3885615). 
“Ministerial Files - Correspondence with General Godley" (NA: Record Group: Allen1, Box: 1, Record: M1/15, Item ID: R22336792).

"Miscellanous files and papers - Correspondence between J Allen and WF Massey, 1st September 1916 - 1st August 1919 [Loose papers]" (NA: Record Group: Allen1, Box:9, Item ID: R22319675).

Prime Minister of New Zealand to Premier of Victoria, 21 February 1925 (NA: Land Settlement (Development), Box: 2, Record: 26/1, Part:10, Item ID: R10639552).

"Signalling, Karori" (NA: Box: 10/t, Item ID: R21371956).

"Territorial Force: Defaulters Undergoing Imprisonment" (NA: Record Group: AD1, Box: 738, Record: 10/587, Item ID: R22429869).

“Territorial Force: Defaulters Undergoing Imprisonment 1918-1919” (NA: Record Group: AD1, Box: 738, Record: 10/566/1, Item ID: R22429858).

"Territorial Force - Conscientious objectors - Treatment and complaints" (NA: Record Group: AD1, Box: 738, Record: 10/566/2, Item ID: R22429859).

"Territorial Force - Religious Objectors Advisory Board" (NA: Record Group: AD1, Box: 734, Record: 10/407/15, Item ID: R22429770).

\section{$\underline{\text { Books }}$}

Archibald Baxter, We Will Not Cease (Auckland: Cape Catley, 2003).

James Hight, Historical Reader for Standard III: Outline History of the British Empire (Christchurch: Whitcombe and Tombs, 1909).

James Hight, Historical Reader for Standard VI: History of the British Colonial Empire (Christchurch: Whitcombe and Tombs, 1911).

William Gillies, Historical Reader for Standard V: The Story of the British Empire from the Beginning of the Stuart Period to the Reign of Queen Victoria (Christchurch: Whitcombe and Tombs, 1909). 
John Salmond, Essays in Jurisprudence and Legal History (London: Stevens and Haynes, 1891).

John Salmond, Jurisprudence, or the Theory of the Law $2^{\text {nd }}$ edn. (London: Stevens and Haynes, 1907).

George von Zedlitz, The Search for a Country: The Autobiography of G.W. von Zedlitz (Plymouth: Paul's Book Arcade, 1963).

Our Nation's Story: Standard III (New Zealand: Whitcombe and Tombs, 1928), p.182.

Our Nation's Story: Standard VI (New Zealand: Whitcombe and Tombs, c.1928-35).

The Police Force Act, 1913, Police Force Amendment Act, 1919, and Regulations (Wellington: Government Printer, 1920).

Report of the Commission on Education in New Zealand (Wellington: Government Printer, 1962).

School Journal Part II, VIII, 5, (June 1914).

Southern Cross History No.3 (Christchurch: Whitcombe and Tombs, 1903).

\section{Secondary Sources}

\section{$\underline{\text { Books }}$}

Paul Baker, King and Country Call: New Zealanders, Conscription and the Great War (Auckland: Auckland University Press, 1988).

J.M. Barrington and T.H. Beaglehole, Maori Schools in a Changing Society (Wellington: New Zealand Council for Educational Research, 1974). 
Michael Bassett, Sir Joseph Ward: A Political Biography (Auckland: Auckland University Press, 1993).

Michael Bassett, The State in New Zealand 1840-1984: Socialism Without Doctrines? (Auckland: Auckland University Press, 1998).

Arthur P. Bates, The Bridge to Nowhere: The III-Fated Mangapurua Settlement (Wanganui: Wanganui Newspapers, 1981).

J.C. Beaglehole, Victoria University College (Wellington: New Zealand University Press, 1949).

James Belich, Paradise Reforged (Auckland: Penguin Books, 2001).

Conrad Bollinger, Grog's Own Country (Wellington: Price Milburn \& Co., 1959).

Nicholas Boyack, Behind the Lines: The Lives of New Zealand Soldiers in the First World War (Wellington: Allen and Unwin, 1989).

Nicholas Boyack and Jane Tolerton, In The Shadow of War: new Zealand Soldiers Talk About World War One and Their Lives (Auckland: Penguin Books, 1990).

Phil Briggs, Looking at the Numbers: A View of New Zealand's Economic History (Wellington: New Zealand Institute of Economic Research, 2003/2007).

Michael Childs, Educator, Exile, Enlightener: Professor G.W. von Zedlitz, (Wellington: Jubilee Publications, 1990).

J. B. Condliffe, New Zealand in the Making $2^{\text {nd }}$ edn. (London: Allen and Unwin, 1959).

D.B Copland, Wheat Production in New Zealand (Auckland: Whitcombe and Tombs, 1920).

Ian Cumming and Alan Cumming, History of State Education in New Zealand 1840 - 1975 (Wellington: Pitman, 1978).

Mark Derby, The Prophet and the Policeman: The Story of Rua Kenana and John Cullen (Nelson: Craig Potton Publishing, 2009). 
Waldo Hilary Dunn and Ivor L.M. Richardson, Sir Robert Stout: A Biography (Wellington: AH and AW Reed, 1961).

Graeme Dunstall, A Policeman's Paradise? Policing a Stable Society, 1918-1945 (Palmerston North: Dunmore Press, 1999).

Stevan Eldred-Grigg, The Great Wrong War (Auckland: Random House, 2010).

J.L. Ewing, The Development of the New Zealand Primary School Curriculum 1877-1970 (Wellington: New Zealand Council for Educational Research, 1970).

Bruce Farland, Farmer Bill : William Ferguson Massey and the Reform Party (Wellington: Bruce Farland, 2008).

Kent Fedorowich, Unfit for Heroes: Reconstruction and Soldier Settlement in the Empire Between the Wars (Manchester: Manchester University Press, 1995).

Alex Frame, Salmond: Southern Jurist (Wellington: Victoria University Press, 1995).

Andrew Francis, 'To Be Truly British We Must Be Anti-German': New Zealand, Enemy Aliens and the Great War Experience, 1914-1919 (Bern: Peter Lang, 2012).

Malcolm Fraser, An Inquiry Into Prices (Wellington: Government Printer, 1920).

W.J. Gardner, William Massey (Wellington: A.H. \& A. W. Reed, 1969).

David Grant, Field Punishment No.1: Archibald Baxter, Mark Briggs and New Zealand's AntiMilitarist Tradition (Wellington: Steele Roberts, 2008).

Barry Gustafson, Labour's Path to Political Independence: The Origins and Establishment of the New Zealand Labour Party 1900-19 (Auckland: Auckland University Press, 1980).

David Hamer, The New Zealand Liberals: The Years of Power, 1891-1912 (Auckland: Auckland University Press, 1988).

G.R. Hawke, The Making of New Zealand: Economic History (Cambridge: Cambridge University Press, 1985). 
Alan Henderson, The Quest for Efficiency: The Origins of the State Services Commission (Wellington: State Services Commission, 1990).

Robert Higgs, Crisis and Leviathan: Critical Episodes in the Growth of American Government (New York: Oxford University Press, 1987).

J. Hight and H.D. Bamford, The Constitutional History and Law of New Zealand (Christchurch: Whitcome and Tombs, 1914).

Richard S. Hill, The Colonial Frontier Tamed: New Zealand Policing in Transition, 1867-1886 (Wellington: GP Books, 1989).

Richard S. Hill, The Iron Hand in the Velvet Glove (Wellington: Dunmore Press, 1995).

H.E. Holland, Armageddon or Calvary: The Conscientious Objectors of New Zealand and "The Process of their Conversion" (Wellington: H.E. Holland, 1919).

D.R. Jenkins, Social Attitudes in the New Zealand School Journal, (Wellington: New Zealand Council for Educational Research, 1939).

David M. Kennedy, Over Here: The First World War and American Society (New York: Oxford University Press, 1980).

Michael King, The Penguin History of New Zealand (Auckland: Penguin, 2003).

Leslie Lipson, The Politics of Equality: New Zealand's Adventures in Democracy $2^{\text {nd }}$ edn. (Wellington: Victoria University Press, 2011).

Margaret McClure, A Civilised Community: A History of Social Security in New Zealand 18981998 (Auckland: Auckland University Press, 1998).

David McGill, Island of Secrets: Matiu/Somes Island in Wellington Harbour (Wellington: Steele Roberts and Silver Owl Press, 2001).

John E. Martin, Honouring the Contract (Wellington: Victoria University Press, 2010).

D. Christine Massey, The Life of Rt. Hon. W. F. Massey P.C., L.L.D., Prime Minister of New Zealand 1912-1925 (Auckland: D. Christine Massey, 1996). 
W.P. Morrell, New Zealand (London: Ernest Benn, 1935).

Melanie Nolan, Breadwinning: New Zealand Women and the State (Christchurch: Canterbury University Press, 2000).

P.J. O’Farrell, Harry Holland: Militant Socialist (Canberra: Australian National University, 1964).

W.H. Oliver, The Story of New Zealand (London: Faber and Faber, 1960).

Erik Olssen, The Red Feds: Revolutionary Industrial Unionism and the New Zealand Federation of Labour 1908-14 (Oxford University Press: Auckland, 1988).

Roger Openshaw, Greg Lee and Howard Lee, Challenging the Myths: Rethinking New Zealand's Educational History (Palmerston North: Dunmore Press, 1993).

Claudia Orange, The Treaty of Waitangi (Wellington: Allen \& Unwin, 1987).

Muriel F. Lloyd Prichard, An Economic History of New Zealand to 1939 (Auckland: Collins, 1970).

Christopher Pugsley, On the Fringe of Hell: New Zealanders and Military Discipline in the First World War (Auckland: Hodder and Stoughton, 1991).

Keith Rankin, Gross National Product Estimates for New Zealand 1859 - 1939, Working paper series 1/91 (Wellington: Graduate School of Business and Government Management, Victoria University of Wellington, 1991).

Eric Richards, Britannia's Children: Emigration from England, Scotland, Wales and Ireland since 1600 (London: Hambledon \& London, 2004).

J.E. Le Rossignol and W.D Stewart, State Socialism in New Zealand (London: George G. Harrap, 1910).

Herbert Roth, George Hogben, A Biography (Christchurch: New Zealand Council for Educational Research, 1952).

Simon Schama, The American Future: A History (London: The Bodley Head, 2008). 
Judith Simon and Linda Tuhiwai Smith ed., A Civilising Mission? Perceptions and Representations of the New Zealand Native Schools System (Auckland: Auckland University Press, 2001).

Keith Sinclair, A History of New Zealand, $2^{\text {nd }}$ edn. (Harmondsworth: Penguin, 1969).

Phillipa Mein Smith, A Concise History of New Zealand (Cambridge: Cambridge University Press, 2005).

Peter Spiller, Jeremy Finn, Richard Boast, A New Zealand Legal History (Wellington: Brookers, 1995).

Hew Strachan, The First World War, Volume 1: To Arms (Oxford: Oxford University Press, 2001).

W.B. Sutch, Price Fixing in New Zealand $2^{\text {nd }}$ edn. (New York: AMS Press, 1968).

Rory Sweetman, Bishop in the Dock: The Sedition Trial of James Liston (Auckland: Auckland University Press, 1997).

A.J.P. Taylor, English History 1914-1945 (London: Oxford University Press, 1965).

Margaret Tennant, The Fabric of Welfare: Voluntary Organisations, Government and Welfare in New Zealand, 1840-2005 (Wellington: Bridget Williams Books, 2007.

Margaret Tennant, Paupers and Providers: Charitable Aid in New Zealand (Wellington: Allen and Unwin, 1989).

David Thomson, A World Without Welfare: New Zealand's Colonial Experiment (Auckland: Auckland University Press, 1998).

Jane Tolerton, Ettie: A Life of Ettie Rout (Auckland: Penguin Books, 1992).

Jock Vennell, The Forgotten General: New Zealand's World War I Commander Major General Sir Andrew Russell (Sydney: Allen and Unwin, 2011).

Duncan Webb, Katherine Sanders and Paul Scott, The New Zealand Legal System Structures and Processes $5^{\text {th }}$ edn. (Wellington: Lexis Nexis New Zealand Limited, 2010). 


\section{Chapters}

James Allen, "New Zealand in the World War," in J.H. Rose, A.P. Newton, E.A. Benians, and J. Hight ed. The Cambridge History of the British Empire, Volume 7: New Zealand (Cambridge: Cambridge University Press, 1933).

Rollo Arnold, "Women in the New Zealand Teaching Profession," in Roger Openshaw and David McKenzie ed. Reinterpreting the Educational Past: Essays in the History of New Zealand Education (Wellington: New Zealand Council for Educational Research).

Stephen Constantine, "Immigration and the Making of New Zealand, 1918-1939," in Stephen Constantine ed. Emigrants and Empire: British Settlement in the Dominions Between the Wars (Manchester: Manchester University Press, 1990).

Stephen Constantine, "Introduction: Empire Migration and Imperial Harmony," in Stephen Constantine ed. Emigrants and Empire: British Settlement in the Dominions Between the Wars (Manchester: Manchester University Press, 1990).

Geoff Bertram, "The New Zealand Economy, 1900-2000," in Giselle Byrnes ed., The New Oxford History of New Zealand (Melbourne: Oxford University Press, 2009).

Tom Brooking, "Economic Transformation," in W.H. Oliver and B.R. Williams ed. The Oxford History of New Zealand (Wellington: Oxford University Press, 1981).

Miles Fairburn, "Interpreting 1913: What Are the Important Questions?", in Melanie Nolan ed. Revolution: The 1913 Great Strike in New Zealand (Christchurch: Canterbury University Press, 2005)

Miles Fairburn, "The Farmers Take Over," in Keith Sinclair ed. The Oxford Illustrated History of New Zealand $2^{\text {nd }}$ ed. (Auckland: Oxford University Press, 1996).

Kent Fedorowich, "The Assisted Emigration of British Ex-Servicemen to the Dominions, 1914-1922," in Stephen Constantine ed. Emigrants and Empire: British Settlement in the Dominions Between the Wars (Manchester: Manchester University Press, 1990).

W.J. Gardner, "A Colonial Colony," in W.H. Oliver and B.R. Williams ed. The Oxford History of New Zealand (Wellington: Oxford University Press, 1981). 
Ashley Gould, "Soldier Settlement in New Zealand After World War I: A Reappraisal," in Judith Smart and Tony Wood ed. An Anzac Muster: War and Society in Australia and New Zealand 1914-18 and 1939-45 (Clayton, VIC: Monash Publications in History, 1992).

Glyn Harper, "'Old Bill Was All Right': William Ferguson Massey and the Soldiers," in James Watson and Lachy Paterson ed. A Great New Zealand Prime Minister? Reappraising William Ferguson Massey (Dunedin: Otago University Press, 2011).

Richard Hill, "State Servants and Social Beings: The Role of the New Zealand Police Force in the First World War," (forthcoming chapter).

Michael King, "Between Two Worlds," in ," in W.H. Oliver and B.R. Williams ed. The Oxford History of New Zealand (Wellington: Oxford University Press, 1981).

Jim McAloon, "The New Zealand Economy, 1792-1914," in Giselle Byrnes ed. The New Oxford History of New Zealand (Melbourne: Oxford University Press, 2009).

Ian McLaren, "The Politics of Secondary Education in Victorian New Zealand," in Roger Openshaw and David McKenzie ed. Reinterpreting the Educational Past: Essays in the History of New Zealand Education (Wellington: New Zealand Council for Educational Research).

Erik Olssen, "Towards a Reassessment of WF Massey: One of New Zealand's Greatest Prime Ministers (Arguably)," in James Watson and Lachy Paterson ed. A Great New Zealand Prime Minister? Reappraising William Ferguson Massey (Dunedin: Otago University Press, 2011).

Sir Hubert Ostler, "Bench and Bar 1903-1928," in Robin Cooke Q.C. ed. Portrait of a Profession: The Centennial Book of the New Zealand Law Society (Wellington: A. H. \& A. W. Reed, 1969).

Dorothy Page, Howard Lee and Tom Brooking, "Schooling for a Gendered Future: Gender, Education and Opportunity," in Barbara Brookes, Annabel Cooper and Robin Law ed. Sites of Gender: Women, Men and Modernity in Southern Dunedin, 1890-1939 (Auckland: Auckland University Press, 2003). 
Brad Patterson, "'Every man his own landlord': Mr Massey and the Fight for Freehold, 18941912," in James Watson and Lachy Paterson ed. A Great New Zealand Prime Minister? Reappraising William Ferguson Massey (Dunedin: Otago University Press, 2011).

Hugh Price, "Reading Books and Reading in New Zealand Schools, 1877-1900," in Roger Openshaw and David McKenzie ed. Reinterpreting the Educational Past: Essays in the History of New Zealand Education (Wellington: New Zealand Council for Educational Research).

I.L.M. Richardson, "Sir Robert Stout," in Robin Cooke Q.C. ed. Portrait of a Profession: The Centennial Book of the New Zealand Law Society (Wellington: A. H. \& A. W. Reed, 1969).

Henry E. Smith, "The Modern Privilege: Its Nineteenth-Century Origins," in R.H. Helmholz, Charles M. Gray, John H. Langbein, Eben Moglen, Henry E. Smith, Albert W. Alschuter ed. The Privilege Against Self-Incrimination: Its Origins and Development (Chicago: University of Chicago Press, 1997).

Rory Sweetman, "'Beery Bill the Orangeman': Another Look at William Ferguson Massey," in James Watson and Lachy Paterson ed, A Great New Zealand Prime Minister? Reappraising William Ferguson Massey (Dunedin: Otago University Press, 2011).

Margaret Tennant, "Mixed Economy or Moving Frontier? Welfare, the Voluntary Sector and Government," in Bronwyn Dalley and Margaret Tennant ed. Past Judgement: Social Policy in New Zealand History (Dunedin: University of Otago Press, 2004).

James Watson, "The Tyranny of Distance: New Zealand Meat Exports and the First World War," (Conference Oral Presentation: Presented at "Rethinking the First World War," Victoria University, November 2013).

Keith Williams, "'A Way Out Of Our Troubles': The Politics of Empire Settlement, 19001922," in Stephen Constantine ed. Emigrants and Empire: British Settlement in the Dominions Between the Wars (Manchester: Manchester University Press, 1990).

Gaynor Whyte, "Beyond the Statute: Administration of Old-age Pensions to 1938," in Bronwyn Dalley and Margaret Tennant ed. Past Judgement: Social Policy in New Zealand History (Dunedin: University of Otago Press, 2004). 


\section{$\underline{\text { Journal Articles }}$}

Tom Brooking, "Use it or Lose it: Unravelling the land debate in late nineteenth-century New Zealand," New Zealand Journal of History 30, 1 (1996).

Bronwyn Dalley, "Lolly Shops 'of the Red-Light Kind' and 'Soldiers of the King'," New Zealand Journal of History 30, 1 (1996).

Alex Frame, "Salmond, Necessity, and the State," Victoria University of Wellington Law Review 38, 4 (2007).

W.J. Gardner, “The Rise of W.F. Massey, 1891-1912," Political Science 13, no.1 (1961).

W.J. Gardner, "W.F. Massey in Power," Political Science 13, no.2 (1961).

Jeanine Graham, "Young New Zealanders and the Great War: exploring the impact and legacy of the First World War, 1914-2014," Paedegogica Historica 44, 4, (2008).

Ashley Gould, "From Taiaha to Ko: Repatriation and Land Settlement for Maori Soldiers in New Zealand After the First World War," War and Society 28, 2 (2009).

David Hamer, "The Second Ballot: A New Zealand Electoral Experiment," New Zealand Journal of History 21, 2 (1987).

Dane Kennedy, "Empire Migration in Post-War Reconstruction: The Role of the Oversea Settlement Committee, 1919-1920," Albion: A Quarterly Journal Concerned with British Studies 20, 3 (1988).

John H. Langbein, "The Historical Origins of the Privilege Against Self-Incrimination at Common Law," Michigan Law Review 92 (1993-4).

Steven Loveridge, "Soldiers and Shirkers: Modernity and New Zealand Masculinity During the Great War," New Zealand Journal of History 47, 1 (2013).

Barrie MacDonald and David Thomson, "Mortgage Relief, Farm Finance, and Rural Depression in New Zealand in the 1930s," New Zealand Journal of History 21, 2 (1987). 
E.P. Malone, "The New Zealand School Journal and the Imperial Ideology," New Zealand Journal of History 17, 1 (1973).

Colin McGeorge, "Childhood's Sole Serious Business," New Zealand Journal of History 40, 1 (2006).

Colin McGeorge, "'New Zealand' in New Zealand School Books Before 1930," History Now 10, 2 (2005).

Radhika Viyas Mongia, "Race, Nationality, Mobility: A History of the Passport," Public Culture $11(3)$.

P.S. O'Connor, “The Awkward Ones: Dealing With Conscience, 1916-1918," New Zealand Journal of History 8, 2 (1974).

P.S. O'Connor, "Some Political Preoccupations of Mr Massey, 1918-20," Political Science 18, no.2 (1966).

W. H. Oliver and Margaret Tennant, "Social Welfare: Social Justice or Social Efficiency?", New Zealand Journal of History 13, no.1 (1979).

Rachel Patrick, "'An Antidote to Bookishness': Local History, Educational Practices and Colonialism in New Zealand Primary Schools, 1900-1940," New Zealand Journal of History 45, 2 (2011).

National Education, 1924.

\section{$\underline{\text { Theses }}$}

Tristan Egarr, "Am I My Brother's Keeper?" (BA Hons Dissertation, University of Otago, 2006).

Tristan Egarr, "Discipline and Defence: The Military Influence on Policing and Imprisonment, c.1870-1913" (MA Thesis, Victoria University of Wellington, 2010).

A.J. Everton, "Government Intervention in the New Zealand Economy, 1914-1918 - its aims and effectiveness" (MA thesis, Victoria University of Wellington, 1995). 
Ashley Gould, "Proof of Gratitude? Soldier Land Settlement in New Zealand After World War I" (PhD Thesis: Massey University, 1992).

Richard G.H. Kay, "In Pursuit of Victory: British-New Zealand Relations During the First World War" (PhD Thesis: University of Otago, 2001).

G.D. Lee, "From Rhetoric to Reality: A History of the Development of the Common Core Curriculum in New Zealand Post-Primary Schools," (PhD Thesis: University of Otago, 1991).

Steven Loveridge, "Sentimental Equipment: New Zealand, the Great War and Cultural Mobilisation," (PhD Thesis: Victoria Univeristy of Wellington, 2013).

Roger Openshaw, "The Patriot Band - The School Cadets From Their Evolution to the Great War," (MA Thesis: Massey University, 1973).

J.M. Robertson, 'The Housing Problem in New Zealand', (Master of Commerce Thesis, University of New Zealand, 1941).

Justin Strang, "Welfare in Transition: Reform's Income Support Policy, 1912-1928," (MA thesis, Victoria University of Wellington, 1992).

\section{$\underline{\text { Websites }}$}

Tim Beaglehole, "Fraser, Peter," in Dictionary of New Zealand Biography, Te Ara - the Encyclopedia of New Zealand, updated 25-Sep-2013, URL: http://www.TeAra.govt.nz/en/biographies/4f22/fraser-peter.

Tim Beaglehole, "Zedlitz, George William Edward Ernest von," in Dictionary of New Zealand $\begin{array}{lllll}\text { Biography, } & \text { updated } & 30 & \text { October } & \text { URL: }\end{array}$ http://www.TeAra.govt.nz/en/biographies/3z1/zedlitz-george-william-edward-ernest-von.

Graham W. A. Bush, "Parr, Christopher James," - Parr, Christopher James', in Dictionary of New Zealand Biography, updated 30 October 2012, URL: http://www.TeAra.govt.nz/en/biographies/3p10/parr-christopher-james. 
Susan Butterworth, "Herdman, Alexander Lawrence," in Dictionary of New Zealand Biography, Te Ara - the Encyclopedia of New Zealand, updated 30-Oct-2012, URL: http://www.TeAra.govt.nz/en/biographies/3h18/herdman-alexander-lawrence.

Graeme Dunstall, “O’Donovan, John," in Dictionary of New Zealand Biography, updated 30 October 2012, URL: http://www.TeAra.govt.nz/en/biographies/3o2/odonovan-john.

Alex Frame, "Salmond, John William", in Dictionary of New Zealand Biography, Te Ara - the Encyclopedia of New Zealand, updated 30-Oct-2012, URL: http://www.TeAra.govt.nz/en/biographies/3s1/salmond-john-william.

W. J. Gardner, "Bell, Francis Henry Dillon," in Dictionary of New Zealand Biography, Te Ara the Encyclopedia of New Zealand, updated 5-Jun-2013 URL: http://www.TeAra.govt.nz/en/biographies/2b16/bell-francis-henry-dillon.

Barry Gustafson, "Massey, William Ferguson," in Dictionary of New Zealand Biography, Te Ara - the Encyclopedia of New Zealand, updated 30-Oct-2012, URL: http://www.TeAra.govt.nz/en/biographies/2m39/massey-william-ferguson.

David Hamer, "Stout, Robert", in Dictionary of New Zealand Biography, Te Ara - the Encyclopedia of New Zealand, updated 30-Oct-2012, URL: http://www.TeAra.govt.nz/en/biographies/2s48/stout-robert.

Richard S. Hill, "Cullen, John," in Dictionary of New Zealand Biography, updated 30 October 2012, URL: http://www.TeAra.govt.nz/en/biographies/3c42/cullen-john.

Gregory Lee, "Hanan, Josiah Alfred," in Dictionary of New Zealand Biography, updated 30 October 2012, URL: http://www.TeAra.govt.nz/en/biographies/3h5/hanan-josiah-alfred.

Ian McGibbon, "Allen, James," in Dictionary of New Zealand Biography, Te Ara - the Encyclopedia of New Zealand, updated 30-Oct-2012, URL: http://www.TeAra.govt.nz/en/biographies/3a12/allen-james.

David McKenzie, "Habens, William James," in Dictionary of New Zealand Biography, updated 30 October 2012, URL: http://www.TeAra.govt.nz/en/biographies/2h1/habens-williamjames. 
Gavin McLean, "The 'Bridge to Nowhere'," updated 8-Oct-2014, URL: http://www.nzhistory.net.nz/media/photo/bridge-nowhere, (Ministry for Culture and Heritage).

Gavin McLean, "Mills, James," in Dictionary of New Zealand Biography, Te Ara - the Encyclopedia of New Zealand, updated 20-Nov-2013, URL:: http://www.TeAra.govt.nz/en/biographies/2m48/mills-james.

Patrick O'Farrell, "Holland, Henry Edmund", in Dictionary of New Zealand Biography, Te Ara - the Encyclopedia of New Zealand, updated 30-Oct-2012, URL: http://www.TeAra.govt.nz/en/biographies/3h32/holland-henry-edmund.

Chris Pugsley, "Russell, Andrew Hamilton," in Dictionary of New Zealand Biography, updated 30 October 2012, URL: http://www.TeAra.govt.nz/en/biographies/3r34/russell-andrewhamilton.

Geoffrey W. Rice, "Russell, George Warren," in Dictionary of New Zealand Biography, Te Ara - the Encyclopedia of New Zealand, updated 30-Oct-2012, URL: http://www.TeAra.govt.nz/en/biographies/2r31/russell-george-warren.

Len Richardson, "Semple, Robert," in Dictionary of New Zealand Biography, Te Ara - the Encyclopedia of New Zealand, updated 30-Oct-2012, URL: http://www.TeAra.govt.nz/en/biographies/3s11/semple-robert.

Len Richardson, "Webb, Patrick Charles," in Dictionary of New Zealand Biography, Te Ara the Encyclopedia of New Zealand, updated 1-Apr-2014, URL: http://www.TeAra.govt.nz/en/biographies/3w5/webb-patrick-charles.

Herbert Roth, "Hogben, George," in Dictionary of New Zealand Biography, updated 30 October 2012, URL: http://www.TeAra.govt.nz/en/biographies/2h44/hogben-george.

Peter Spiller, "Chapman, Frederick Revans," in Dictionary of New Zealand Biography, updated 30 October 2012, URL: http://www.TeAra.govt.nz/en/biographies/3c10/chapmanfrederick-revans. 
“Parliamentarians and World War I," updated 6-Nov-2008, URL: http://www.parliament.nz/en-nz/features/00NZPHomeNews061120081/parliamentariansand-world-war-i.

Sounds Historical, 30 May 2011 (National Radio, http://www.radionz.co.nz/national/programmes/soundshistorical/20110529). 
